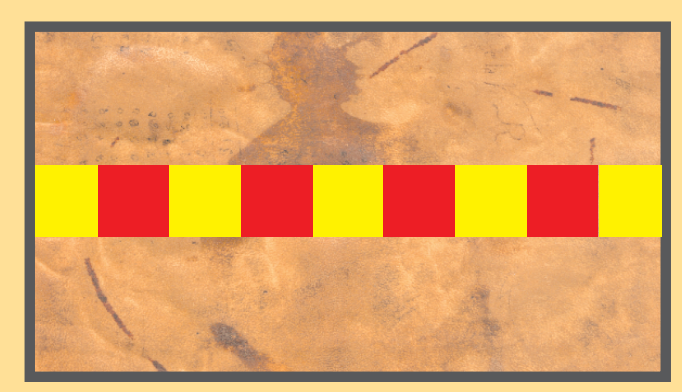

Escritura, poder y archivo La organización documental de la Diputación del reino de Aragón (siglos XV-XVIII) 

ESCRITURA, PODER Y ARCHIVO.

LA ORGANIZACIÓN DOCUMENTAL DE LA DIPUTACIÓN

DEL REINO DE ARAGÓN (SIGLOS XV-XVIII) 



\section{ESCRITURA, PODER Y ARCHIVO. LA ORGANIZACIÓN DOCUMENTAL DE LA DIPUTACIÓN DEL REINO DE ARAGÓN (SIGLOS XV-XVIII)}

Diego Navarro Bonilla 


\section{FICHA CATALOGRÁFICA}

NAVARRO BONILLA, Diego

Escritura, poder y archivo : la organización documental de la Diputación del reino de Aragón : (siglos XV-XVIII) / Diego Navarro Bonilla. - Zaragoza : Prensas Universitarias de Zaragoza, 2004

316 p. ; $22 \mathrm{~cm}$. - (Humanidades ; 44)

ISBN 84-7733-682-2

1. Archivos-Aragón-S. XV-XVIII. 2. Aragón (Reino)-Historia-Fuentes-S. XV-XVIII. Prensas Universitarias de Zaragoza. II. Título. III. Serie: Humanidades (Prensas Universitarias de Zaragoza) ; 44

$930.253(460.22) \ll 14 / 17 »$

No está permitida la reproducción total o parcial de este libro, ni su tratamiento informático, ni la transmisión de ninguna forma o por cualquier medio, ya sea electrónico, mecánico, por fotocopia, por registro u otros métodos, ni su préstamo, alquiler o cualquier forma de cesión de uso del ejemplar, sin el permiso previo y por escrito de los titulares del Copyright.

(C) Diego Navarro Bonilla

(C) De la edición española, Prensas Universitarias de Zaragoza

1. a edición, 2004

Ilustración de la cubierta: José Luis Cano

Colección Humanidades, n. ${ }^{\circ} 44$

Directora de la colección: Rosa Pellicer Domingo

Editado por Prensas Universitarias de Zaragoza

Edificio de Ciencias Geológicas

C/ Pedro Cerbuna, 12

50009 Zaragoza, España

Prensas Universitarias de Zaragoza es la editorial de la Universidad de Zaragoza, que edita e imprime libros desde su fundación en 1542.

Impreso en España

Imprime: Cometa, S.A.

D.L.: Z-86-2004 
A mis padres, con todo el cariño reforzado por el paso de los años A María José, por todo 



\section{ABREVIACIONES}

A.C.A. Archivo de la Corona de Aragón

A.D.P.Z. Archivo de la Diputación Provincial de Zaragoza

A.G.A. Archivo General de la Administración

(Alcalá de Henares)

A.G.S. Archivo General de Simancas

A.H.N. Archivo Histórico Nacional

A.H.P.H. Archivo Histórico Provincial de Huesca

A.H.P.Z. Archivo Histórico Provincial de Zaragoza

A.M.Z. Archivo Municipal de Zaragoza

A.P.R. Archivo del Palacio Real de Madrid

A.P.Z. Archivo de Protocolos Notariales de Zaragoza

B.N.E. Biblioteca Nacional de España (Madrid)

B.U.Z. Biblioteca General Universitaria de Zaragoza

R.A.H. Real Academia de la Historia 



\section{INTRODUCCIÓN}

Cuando en agosto de 1703 el cronista Diego José Dormer puso en conocimiento de los diputados del reino de Aragón su descontento por la lentitud en la percepción de las ayudas pecuniarias para visitar archivos, rescatar papeles y apresar la información documentada, se llegó a un punto muy significativo en la comunicación, notablemente deteriorada, entre ambas partes. Cronista y diputados acabaron por quebrar un compromiso aceptado años antes con el nombramiento del historiógrafo oficial del reino aragonés. Tal fue el desaire manifestado por Dormer que, como indicamos en su apartado correspondiente, llevado por su desaliento y patente enfado, llegó a dudar de la importancia de los datos suministrados por los registros y legajos custodiados en el archivo del reino de Aragón. Los molestos diputados, a tenor de las continuas y, en cierto modo, cansinas y repetitivas peticiones y permisos para visitar otros archivos donde proseguir la búsqueda documental para completar sus Anales, llegaron a personificar el archivo del reino atribuyendo a este depósito sentimientos de pesadumbre por la vacilación del arcediano Dormer en cuanto a la riqueza informativa ofrecida por sus series documentales: «No se contenta el arzediano con tener quexosos a los diputados, sino que también quiere que lo esté el Archibo del Reyno, diciendo que no ay en él noticias para la continuación de los Anales».

Tres siglos después, a pesar del intermedio luctuoso acaecido en 1809, la investigación emprendida sobre la formación, organización y riqueza, a todas luces notabilísima, del archivo del reino de Aragón, tiene en estas páginas un renovado enfoque y acercamiento. La memoria histórica aragonesa, asentada fundamentalmente en la documentación que conforma- 
se durante los siglos XV a XVIII el solemne archivo del reino, mereció hace años nuestra atención y reflexión. Cristaliza dicho interés, cinco años después, en estas páginas que responden a la voluntad de analizar uno de los principales archivos del Antiguo Régimen en Aragón, nacido de la no menos imprescindible actuación de la Diputación del reino de Aragón como institución vertebradora de la política, la hacienda y la sociedad del reino desde el siglo XV hasta los albores del XVIII.

Antes de dar a conocer el desarrollo del camino emprendido y los puertos a los que la senda de la investigación nos han llevado durante este tiempo, es de toda justicia y sano ejercicio para el espíritu abrir el cuaderno de viaje y reconocer a todos cuantos en un momento $u$ otro del trayecto animaron la línea emprendida, apoyaron nuestro trabajo y constituyeron firmes puntales tanto en lo personal como en lo intelectual para la consecución de los objetivos.

Mi formación inicial se desarrolló en la Universidad de Zaragoza, y más concretamente en su Departamento de Ciencias de la Documentación e Historia de la Ciencia. Como diplomado en Biblioteconomía y Documentación, la estrecha relación mantenida con un grupo de docentes del citado departamento se consolidó personal y académicamente de manera notable cuando pasé a formar parte de él calidad de becario de investigación del programa de formación de personal universitario del Ministerio de Educación y Ciencia durante el período comprendido entre 1998 y 1999. Por ello, en primer lugar debo hacer constar mi más sincero agradecimiento y reconocimiento personal al doctor Miguel Ángel Esteban Navarro, director y tutor fraternal de mis trabajos de investigación, cuyos resultados se deben en buena medida a su buen hacer y a la excelente complicidad mantenida, así como una reconocida paciencia y seguimiento antes incluso de que el tema de investigación fuese planteado. También dentro de dicho departamento resulta obligado hacer constar mi profundo agradecimiento a la doctora Luisa Orera Orera, por tantos y tan buenos consejos destilados en numerosas y amenas horas de conversación. A las doctoras Pilar Gay Molins y Adelaida Allo Manero, quienes siempre tuvieron excelentes y cariñosas palabras de ánimo hacia mis trabajos. De igual modo, a los doctores Antonio Paulo Ubieto Artur, Isabel Ubieto Artur, Jesús Tramullas Saz, Ana Isabel Sánchez Casabón y Genaro Lamarca Langa, por su constante amistad y apoyo a lo largo de 
todos estos años. En el mismo recinto de la Universidad de Zaragoza, he pasado mucho tiempo investigando en el depósito de la biblioteca de la Facultad de Filosofía y Letras. Su directora, doña Matilde Cantín, nos ha brindado todo su apoyo y amistad, no sólo para consultar los fondos allí albergados. Su amistad y cariño ha trascendido esta relación, llegando a compartir pupitre en nuestra formación profesional universitaria. A Matilde y a Inma, queridas y entrañables amigas, mi reconocimiento, mi gratitud y mi cariñoso recuerdo.

Sin salir de Zaragoza, mantengo una gran deuda personal y profesional con los miembros de la cátedra "Barón de Valdeolivos» de la Institución «Fernando el Católico» por tantos años de reuniones, trabajos conjuntos y amistad sincera. A mi querido director de cátedra Guillermo Redondo Veintemillas, al secretario Alberto Montaner Frutos y a los entrañables colaboradores Leonardo Blanco Lalinde, Enriqueta Clemente García y a nuestra querida Mari Cruz. He nombrado al profesor Alberto Montaner, quien en su cargo de secretario de la cátedra "Barón de Valdeolivos» ha animado y apoyado decisivamente en todo momento mis investigaciones acerca del archivo de la Diputación del reino de Aragón. Sin embargo, mi consideración personal trasciende la vertiente institucional y académica para subrayar un reconocimiento centrado en mi más sincera admiración y gratitud por muchos años de apoyo y amistad, corroborados diariamente en múltiples conversaciones, encuentros y trabajos conjuntos.

Mi actual situación profesional y académica me ha llevado a formar parte como profesor ayudante desde el año 1999 del Departamento de Biblioteconomía y Documentación de la Universidad Carlos III de Madrid. La ayuda de sus miembros debe ser consignada en estas líneas con verdadero y reconocido agradecimiento. En especial para sus directores, José Antonio Moreiro González, queridísimo codirector de mi tesis doctoral, y Elías Sanz Casado, por su constante amistad y ánimo para seguir adelante. También para Arturo Martín Vega, con quien he tenido el placer de comenzar mi profesión docente, y muy especialmente para Pilar Azcárate, entrañable compañera, amiga y apoyo insustituible de tantos momentos nacidos al calor de intereses e investigaciones compartidas. Finalmente, pero no por ello menos importante, mi agradecimiento se centra ahora en el Departamento de Humanidades de mi Universidad, y muy concretamente en el profesor Enrique Villalba, a quien agradezco muy de veras su magnífica orientación académica y sus sabias indicaciones en torno a la 
cultura escrita. Desde Alcalá de Henares, la sabiduría de Antonio Castillo, no menor que su amistad, ha guiado numerosas páginas de este trabajo. En estas líneas registro mi admiración por su capacidad de trabajo, su espíritu pionero y su siempre dispuesta generosidad de tiempo y materiales. También desde esta ciudad, y en el área de Ciencias y Técnicas Historiográficas, quiero destacar el apoyo brindado por Carlos Sáez. Desde Simancas, José Luis Rodríguez de Diego e Isabel Aguirre, queridos amigos y profundos conocedores de la historia de los archivos, han animado con no poco aliento muchos pasajes de este trabajo, por lo que les agradezco profundamente sus constantes ánimos, amabilidad y sabias indicaciones sobre algunos de los temas que hemos planteado. A Manuel Fuertes quiero agradecerle su sincero y entrañable sentido de la amistad y nuestra compartida pasión por el solar aragonés y su realidad histórica y actual. Desde la península y hacia ultramar se dirige en este recordatorio mi gratitud, mi reconocimiento y mi voto de amistad para el profesor George Greenia, del William \& Mary College de Williamsburg (Virginia, Estados Unidos), por su amable acogida y por su excelente talla personal. También a Samuel y Sandra, por un mes inolvidable en Ann Arbor (Michigan).

Por último, mi gratitud y reconocimiento para María José, mi inseparable compañera de viaje vital, por su apoyo, cariño y comprensión a lo largo de todos estos años. También mi recuerdo y agradecimiento a mis padres, en los que tantas veces pienso y a los que otras tantas echo de menos.

Para centrar el objeto de estudio y el método seguido en este trabajo, resulta imprescindible hacer la aproximación preliminar expuesta a continuación. La Diputación del reino de Aragón fue la institución emanada de las Cortes aragonesas para compartir el gobierno del reino de Aragón con el monarca y con la corte del Justicia, que rigió buena parte de la actividad política, fiscal y judicial del antiguo reino desde finales del siglo XIV hasta comienzos del XVIII, momento en que la Nueva Planta borbónica supuso el cese de su actividad. La Diputación desarrolló una amplia práctica administrativa para ejercer las funciones y las actividades que le eran inherentes, y su funcionamiento se sostuvo en un proceso más o menos regulado de creación y tramitación burocrática de los documentos; el cual encontró, con objeto de aumentar su eficiencia, su natural y necesario complemento en un elaborado programa de custodia y organización de los documentos producidos en un archivo, que se convirtió de este modo en 
un elemento clave de la vida interna de la Diputación y en el centro de la memoria de Aragón.

La creación de un archivo del reino permitió que los fondos generados por la Diputación aragonesa constituyeran una fuente informativa de primer orden tanto para los actos de gobierno, administración, servicios y hacienda en los que esta institución fue competente durante toda su existencia, como después de su desaparición para el conocimiento de la realidad económica y fiscal de Aragón por parte de la Corona durante el siglo XVIII. Asimismo, la existencia del archivo permitió que los documentos fueran utilizados como testimonio escrito del pasado, dentro de un ambicioso plan de elaboración de un discurso histórico oficial legitimador, junto con la codificación del derecho foral aragonés, del singular ordenamiento jurídico y político de Aragón; lo cual repercutió, a su vez, en el continuo interés demostrado por los diputados por la adecuada conservación de la documentación.

Pese a su importancia, la documentación conservada en el archivo de la Diputación del reino de Aragón ha llegado hasta nuestros días con sensibles lagunas. Porque en 1809 , el antiguo edificio donde se albergaba el archivo de la Diputación fue bombardeado y posteriormente incendiado durante el segundo sitio del ejército napoleónico a la ciudad de Zaragoza, lo que provocó la pérdida de una parte no pequeña de los documentos que contenía. La mayor parte de los documentos que se salvaron se hallan actualmente en el archivo histórico de la Diputación Provincial de Zaragoza, si bien también se encuentran restos dispersos por la geografía archivística española. Únicamente gracias a los inventarios coetáneos conservados se puede conocer con detalle el contenido real del archivo, datos que se completan con los legajos y piezas archivísticas rescatadas de la destrucción de 1809. En nuestro siglo, el ya lejano trabajo de don Eduardo Ibarra elaborado en 1909 es el instrumento específico que orienta someramente al investigador que desea adentrarse en cualquier aspecto relacionado con la Diputación del reino. Por otra parte, el inventario de los documentos de este archivo, elaborado a mediados del siglo XVIII por el archivero José de Yoldi, recientemente recuperado y editado, completa el conocimiento real que se tenía hasta la fecha de dicho depósito. ${ }^{1}$ Recientemen-

1 Diego Navarro Bonilla (2000a). 
te se ha elaborado una guía del archivo de la Diputación Provincial de Zaragoza, que custodia el fondo de la Diputación que formaba el antiguo archivo del reino de Aragón. No obstante, a pesar de que el fondo de la Diputación del reino constituye la documentación generada por la principal institución aragonesa junto con el Justicia de Aragón, lo que da idea de su capital importancia y de la riqueza de su contenido, se sigue insistiendo en su práctica desaparición, lo que repercute en un desconocimiento del fondo y en una minusvalorada posición dentro del panorama archivístico español. ${ }^{2}$

Este trabajo tiene por objetivo el conocimiento del contenido real del fondo documental generado y reunido por la Diputación del reino de Aragón, con el fin de proponer una organización adecuada mediante la aplicación del método de reconstrucción del orden original de los documentos, que explicaremos en el siguiente apartado. Este objetivo general se concreta, a su vez, de acuerdo con el contenido de ese método, en tres objetivos específicos: la comprensión de la naturaleza institucional de la Diputación del reino de Aragón, la determinación de las series documentales producidas por esta institución y la elaboración de un cuadro de clasificación del fondo. A ellos se incorpora, en atención al valor histórico del fondo, un cuarto objetivo específico: el análisis de los fines a los que sirvió el archivo y del uso coetáneo que se hizo de la documentación, intentando comprender por qué y cómo los diputados y los cronistas del reino instrumentalizaron la memoria escrita del reino al servicio, respectivamente, del gobierno y la administración y de la historia.

Nuestra investigación se sitúa en el campo de la Ciencia de la Información Documental y, en concreto, en el de una de sus disciplinas específicas: la Archivística. Dentro del método científico general, la Archivística comparte con otras disciplinas sociales y humanísticas una especialización denominada «método de aproximaciones sucesivas», que parte de la idea de que todo lo que podemos conseguir son soluciones aproximadas a los problemas planteados, no certezas de validez universal. Pero sin que de ello resulte la renuncia al planteamiento de hipótesis, la constatación y el contraste de conjeturas, la derivación de consecuencias lógicas, la determinación de dominios de aplicación y la posibilidad de formular nuevos pro-

2 Luis Miguel de la Cruz Herranz (2000), p. 15. 
blemas y preguntas para la investigación. Dicho método para el conocimiento de la parcela de la realidad de la que se ocupa la Archivística, cuya madurez científica comienza a alcanzar, guía a su vez una praxis de intervención en esa realidad que es su objeto, que ha demostrado sobradamente su operatividad.

En el caso concreto de la identificación, la organización y la conservación de los documentos generados, reunidos y recibidos por un ente físico o moral en el ejercicio de su actividad, esta praxis se conoce como "método de reconstrucción del orden original de los documentos», ya que se basa en el sistema de producción documental seguido por ese ente. Por consiguiente, nuestra investigación parte, como no podía ser de otro modo, de la convicción de que la aplicación de los principios rectores, las reglas y los criterios de intervención y las actividades, las habilidades y los recursos técnicos que componen este método de reconstrucción es un requisito indispensable tanto para establecer y comprender los procesos de producción y de custodia del fondo documental de la Diputación del reino de Aragón, como para proponer una organización adecuada de este fondo por operativa. Operatividad que se debe entender desde la perspectiva de la doble eficacia que poseen los resultados de la aplicación de este método para comprender plenamente el significado de cada documento, por reconstruir su contexto de creación, y para permitir una recuperación exhaustiva, específica y pertinente de todos los documentos.

El método de reconstrucción del orden original, por otra parte bien conocido, se desarrolla mediante tres actividades, cuyo ejercicio se basa en el respeto de los principios de procedencia y de orden natural. ${ }^{3}$ La primera actividad consiste en la comprensión de la naturaleza de la institución a partir del análisis de sus fines, sus órganos, sus funciones y su práctica administrativa, teniendo en cuenta tanto la evolución de estos elementos a lo largo del tiempo como las relaciones que se establecen entre ellos. La segunda actividad consiste en la identificación y la delimitación de las series documentales a partir del análisis de los modos de producción documental, los caracteres externos e internos de los tipos de documentos y las operaciones de conservación, descripción y organización archivística reali-

3 Michel Duchein (1977). Elio Lodolini (1993). Miguel Ángel Esteban Navarro (1995) y (1997). Mari Paz Martín Pozuelo (1996). 
zadas en su tiempo. Y la tercera actividad pretende plasmar la estructura jerárquica de las agrupaciones documentales delimitadas mediante esas operaciones en un cuadro de clasificación del fondo, el cual servirá al actual archivo custodio de la mayor parte de la documentación conservada de fundamento para diseñar un adecuado plan de acceso.

Asimismo, el presente estudio parte de una concepción del documento de archivo centrada en su naturaleza involuntaria y espontánea. Esta característica se halla ligada a la idea de que un fondo documental existe en función de una estructura organizativa previa, con unos fines, funciones y actividades delimitadas por parte de la institución productora, que se ha servido del acto documental como auxilio de su práctica administrativa y como vehículo para fundamentar jurídicamente su cotidianeidad operativa. Y todo ello, siguiendo las líneas maestras de una tramitación administrativa que, en principio, debe seguir los postulados de las prácticas burocráticas e institucionales del momento histórico concreto. Es decir, el documento administrativo emanado por una institución se impregna forzosamente de las características funcionales y estructurales de ésta, en cada una de sus etapas históricas. La documentación producida por la Diputación del reino de Aragón no es ninguna excepción a este postulado fundamental de la Archivística; por lo cual, de forma natural y como consecuencia directa, las transformaciones de la Diputación, inherentes por otra parte al normal devenir histórico de cualquier institución, tuvieron su repercusión inmediata en la génesis y la custodia de sus documentos. En consecuencia, al mismo tiempo, las conclusiones que se obtengan del análisis del archivo de la Diputación con esta perspectiva servirán de apoyo ineludible para la comprensión de la institución productora de la documentación custodiada en dicho archivo.

En definitiva, los avatares del archivo de la Diputación de Aragón no constituyen un apartado cerrado en sí mismo. Muy al contrario, el estudio de los modos de custodia, organización y utilización del testimonio escrito de la Diputación aragonesa es, desde el momento en que fueron objeto de una práctica deliberada, una labor ineludible para aplicar correctamente el método de reconstrucción del orden original y, por tanto, conocer el fondo generado y reunido por esta institución. Además, atendiendo al carácter fragmentario y desorganizado del fondo que ha llegado hasta nuestros días, ese estudio se hace aún más necesario si cabe, ya que su obje- 
to de análisis, el archivo, es la principal fuente para poder identificar las series documentales y establecer el proceso administrativo mediante el que se produjeron; de modo que el conocimiento del archivo trasciende el interés histórico que por sí mismo ya tiene.

Un trabajo de esta naturaleza no se puede nutrir únicamente de la teoría y el método de investigación archivísticos, sino que exige contar también con las aportaciones de otras disciplinas. Fundamentalmente, asumimos las directrices y orientaciones marcadas desde la nueva concepción de la Historia social de la cultura escrita y utilizamos algunos modos de análisis y resultados provenientes de la Historia de las instituciones y de la administración, como rama derivada de la Historia del derecho.

Como paso previo al desarrollo de la investigación, es preciso dar cuenta de las contribuciones científicas al conocimiento de la Diputación del reino y su universo documental. Se identifican tres ámbitos claramente vinculados. En primer lugar, los trabajos que analizan la Diputación desde un enfoque derivado de la historia institucional, al amparo de la historia del derecho y la historia medieval y moderna. En segundo lugar, aquellos estudios centrados en el análisis de la producción documental de la institución propiamente dicha, mucho menos abundantes y que requieren del concurso del ámbito anterior. Finalmente, se sitúan todos aquellos trabajos dedicados a la explotación de las fuentes documentales generadas por la Diputación del reino para cimentar estudios históricos de muy diversa naturaleza, pero sin detenerse en la propia génesis documental ni en sus procedimientos administrativos ni tampoco en los modos de organizar las escrituras como medio eficaz para el buen funcionamiento institucional.

Como punto de arranque debe citarse el ya clásico trabajo de José Ángel Sesma donde, desde una perspectiva económica y política, se estudia la actividad, organización y atribuciones de la institución desde los prolegómenos de su creación hasta comienzos del siglo XVI, tomando como eje vertebrador de la exposición la figura política de Fernando II de Aragón, quien habría de intervenir activamente en su organización definitiva a fines del siglo $\mathrm{XV} .{ }^{4}$ Es un punto de partida fundamental para aco-

4 José Ángel Sesma Muñoz (1977). 
meter un estudio de las funciones, órganos y prerrogativas de la Diputación del reino de Aragón, que son elementos esenciales para delimitar el ámbito de la producción documental de la institución. También Gregorio Colás y José Antonio Salas analizaron la jurisdicción de la Diputación en el seno de las instituciones aragonesas bajo la monarquía austríaca. ${ }^{5}$ Con posterioridad a estos dos trabajos, apareció en 1991 una monografía elaborada por José Ángel Sesma en colaboración con José Antonio Armillas, que retomaba el estudio de la institución aragonesa desde una concepción generalista. ${ }^{6}$ El apartado dedicado a la antigua Diputación del reino de Aragón supone una importante revisión de la historia de la institución abarcando toda su trayectoria histórica, lo que convierte esta obra en una importante contribución general para su conocimiento. En 1992, el profesor J. A. Armillas publicó en colaboración con Enrique Solano un artículo donde se volvía a repasar la andadura histórica de la institución aragonesa desde sus orígenes hasta detenerse con especial detalle en 1591 y la actitud tomada por la Diputación ante las «alteraciones de Aragón». 7 Dentro de estos trabajos de carácter general acerca de la Diputación del reino debe mencionarse el opúsculo de Ángel Canellas donde se sintetizan varios aspectos ilustrativos de la actividad desplegada por la institución, haciendo hincapié en uno de sus apartados sobre la tipología documental emanada de sus funciones. ${ }^{8} \mathrm{El}$ asunto de las instituciones aragonesas en los siglos XV y XVI, con especial atención a la Diputación y la corte del Justicia, ha sido abordado de nuevo por Luis González Antón en el congreso «La Corona de Aragón y el Mediterráneo». ${ }^{9}$ Del mismo autor se debe desta car el análisis del auge de la Diputación durante el siglo XV en el seno de la política de Alfonso $\mathrm{V}^{10}$ Recientemente, Porfirio Sanz Camañes ha analizado el papel de la Diputación del reino en el contexto de la monarquía hispánica para el período comprendido entre 1640-1680. ${ }^{11}$ Finalmente, ha de incluirse entre estas publicaciones generales sobre la Diputación aragonesa la reciente obra de José Antonio Armillas editada en una colección sobre temas aragoneses. ${ }^{12}$

5 Gregorio Colás Latorre y José Antonio Salas Auséns (1977).

6 José Ángel Sesma y José Antonio Armillas (1991).

7 J. A. Armillas y E. Solano (1992).

8 Ángel Canellas (1979).

9 Luis González Antón (1997).

10 L. González Antón (1999).

11 Porfirio Sanz Camañes (1997).

12 J. A. Armillas (2000). 
Se puede concluir que, hasta el momento, las aproximaciones más o menos extensas realizadas a la Diputación del reino se han desarrollado desde la historia. Sin embargo, no existen trabajos que investiguen la evolución de las funciones y estructuras de la institución y el reflejo de esta evolución en la producción y la salvaguarda de su documentación. El archivo también ha tenido menciones muy exiguas a la vez que fragmentarias, a veces en el seno de estudios más generales centrados en la estructura de la institución.

De ahí la novedad del enfoque propuesto y desarrollado en estas líneas: el análisis y la comprensión, desde la teoría archivística, de los procedimientos documentales llevados a cabo en el seno de la Diputación del reino como producto de su normal funcionamiento $y$, en concreto, de los modos de génesis de los documentos y de custodia en el archivo. Pero se trata de realizar una investigación que también tenga en cuenta las aportaciones de los estudios históricos, ya que las características funcionales y estructurales de la Diputación no permanecieron inmutables desde finales de la Edad Media hasta comienzos del siglo XVIII, como es propio de todo organismo histórico de tan dilatada existencia.

La investigación con fuentes de archivo se ha desarrollado mediante la consulta directa de una variada tipología documental procedente del antiguo archivo de la Diputación del reino, conservada en varios depósitos, de la que se da cuenta pormenorizada en el apartado final dedicado a las fuentes y a la bibliografía empleada. Los volúmenes de compilaciones forales han constituido un elemento básico a la hora de delimitar las competencias generales de la institución, así como su estructura orgánica y funcional. Junto a ellos, la documentación referida a la propia organización y regulación de la institución (ordinaciones, reglamentos internos, etc.) ha sido objeto de especial atención. De igual modo, se ha hecho hincapié en las series de gobierno de la institución (registros de actos comunes), así como en otras de naturaleza económica (registros de ápocas y salarios). De manera más concreta, la documentación referida exclusivamente al archivo del reino constituye una parte importante de las fuentes empleadas en el apartado centrado en los modos de organización de los documentos en el archivo. Así, se detallan aquellos inventarios que, junto con relaciones, memorias, índices y demás instrumentos de descripción, trazan la imagen física e informativa del archivo. Testimonios todos necesarios para reconstruir el contenido real del depósito, toda vez que su estructura se descom- 
puso tras el incendio de 1809 y los posteriores avatares sufridos. Finalmente, la investigación de archivo se ha desarrollado teniendo en cuenta numerosos y desperdigados testimonios referidos de manera directa a la utilización del archivo con fines eminentemente administrativos o bien de erudición histórica. En este sentido, los registros de entradas y salidas de escrituras del archivo, así como la correspondencia y las memorias de los cronistas aragoneses, nos han permitido establecer con mayor precisión los modos de consulta y acceso a la documentación del reino.

Con respecto a los registros de actos comunes de los diputados, la mayor parte de esta serie se custodia en la actual Diputación Provincial de Zaragoza. Sin embargo, existen seis volúmenes que pertenecieron a Pascual de Gayangos y que actualmente se pueden consultar en la Biblioteca Nacional de Madrid. ${ }^{13}$ Según Ricardo del Arco, también existe un volumen del registro de actos comunes de la Diputación, perteneciente al año 1555, en la biblioteca capitular de Zaragoza, así como otro conjunto de manuscritos emanados de la Diputación del reino. ${ }^{14}$ En el archivo de la Diputación Provincial de Zaragoza también se encuentra depositada una de las más importantes recuperaciones de documentos procedentes del archivo del reino y que se daban por perdidos. Fue la efectuada en 1966, cuando se adquirieron a una familia madrileña varios documentos procedentes de la «alacena» del cronista Zurita y nueve volúmenes de cartas responsivas que ocupaban los armarios 48 y 49 del archivo del reino de Aragón bajo la rúbrica «Rexistros de cartas originales». ${ }^{15}$

Para conocer las directrices y la organización de la Diputación del reino, ha resultado obligada la consulta de las disposiciones jurídicas aprobadas en Cortes acerca de la organización y atribuciones de la institución. De éstas, una de las fuentes más interesantes para este propósito se encuentra recogida en el repertorio de Fueros y Actos de Corte de Savall y Penén (1886). Se trata en concreto de las Ordinaciones para el régimen de la Diputación. ${ }^{16}$ A este reglamento de funcionamiento interno debe sumarse el

13 En concreto, son los manuscritos 17451 (1469-1470), 17452 (1483-1484), 17453 (1486-1487), 17454 (1510-1511 y 1513-1514) y 17455 (1579-1580).

14 Ricardo del Arco y Garay (1942), p. 282.

15 Ángel San Vicente Pino y James O. Crosby (1963) y (1968-1969).

16 Existen copias manuscritas de este reglamento en A.D.P.Z., ms. 657, así como en A.M.Z., ms. 15 (1513-1514). Publicadas por Savall y Penén (1866), vol. 2, pp. 320 y ss. 
siempre fructífero Ceremonial y breve relación de todos los cargos y cosas ordinarias de la Diputación del Reino de Aragón hecho en el año de mil seyscientos y once por Lorenzo Ibáñez de Aoiz. Como obra generada en el seno de la Diputación del reino, se debe subrayar su capital importancia y que de ella se conocen hasta la fecha tres manuscritos. ${ }^{17}$ En primer lugar se debe citar el volumen conservado en la Biblioteca General Universitaria de Zaragoza con la signatura ms. 199 y escrito en $1611 .{ }^{18}$ Por nuestra parte, en la Biblioteca Nacional de Madrid hemos comprobado hasta el momento la existencia de dos ejemplares manuscritos, copiado el uno el 2 de junio de $1613^{19}$ y el otro fechado en 1663, más extenso y completo que los anteriores. ${ }^{20}$ Dentro del programa emblemático global desarrollado por la Diputación del reino y sumado a la obra de Ibáñez de Aoiz, se encuentra el breve Ceremonial de los asientos de los consistorios de los Diputados, inquisidores, contadores y iudicantes del Reyno de Aragón, compuesto por el cronista Jerónimo Martel. ${ }^{21}$ En él se incide en el ámbito de la regulación de las formas sociales y emblemáticas en el seno del palacio de la Diputación, por lo que constituye un complemento para el análisis de la estructura organizativa de la institución.

Otra fuente de especial interés para el conocimiento de la documentación procedente del archivo del reino es el conjunto de Apuntaciones his-

17 De hecho, los diputados estipularon de forma clara que los ejemplares de esta obra pasasen al archivo del reino: Lezaun y Tornos, Apuntaciones históricas..., B.N.E., ms. 9824 , f. 68v: «A 28 de mayo [1612], atendido que Lorenzo Ibáñez de Aoyz, teniente de alcayde de la Diputación les había entregado un libro intitulado Ceremonial y breve relación de todos los cargos y cosas ordinarias de la Diputación [...] con esto que tome a su cargo sacar una copia de dicho libro de manera que estará la que entregará a los Señores Diputados para que se ponga en el archivo y allí esté custodiada, porque, si se perdiese, como es cosa contingente, el libro que ha de estar en el consistorio quede siempre guardado el original y no haya sido infructuoso el travajo tan grande y de tan grande importancia». Publicado en Navarro Bonilla (1997a), pp. 201-202.

18 De este ejemplar se realizó una edición facsímil con una utilísima introducción a cargo de José Antonio Armillas y José Ángel Sesma: Ceremonial y brebe [sic] relación de todos los cargos y cosas ordinarias de la Diputación del Reyno de Aragón, Zaragoza, Cortes de Aragón, 1989.

19 Lorenzo Ibáñez de Aoyz, Ceremonial i breve relación de todos los cargos y cosas ordinarias de la diputación del regno de Aragón hecho en el año MDCXI..., Madrid, B.N.E., ms. 987.

20 Ceremonial del Illustrissimo Consistorio del Reyno de Aragón copiado y sacado en limpio el año 1663..., Madrid, B.N.E., ms. 2922.

21 Diego Navarro Bonilla (ed.) (1999). 
tóricas de Tomás Fermín de Lezaun y Tornos (1747-1778), extractos de las noticias más relevantes contenidas en los registros de actos comunes de la Diputación. Dichas Apuntaciones se recogieron en cinco volúmenes, de los que falta actualmente el correspondiente al período de 1621 a 1665. Conocemos este manuscrito del hijo del archivero Lezaun gracias a dos copias: una que incluye tres volúmenes custodiados en la Biblioteca Nacional de Madrid y otra, en cuatro volúmenes, custodiada en microfilm en la biblioteca de las Cortes de Aragón.

El trabajo publicado en 1909-1910 por Eduardo Ibarra sigue siendo, como hemos indicado, un instrumento de referencia para conocer los restos documentales que se salvaron del incendio de 1809 y se ubicaron en la actual Diputación Provincial de Zaragoza. ${ }^{22}$ No obstante, la integración de tipos documentales notablemente diferenciados dentro de un mismo epígrafe, como es el caso de los documentos de "régimen financiero", induce en algunas ocasiones a errores de localización. ${ }^{23}$ Por ello, a pesar del valor indudable de este intento de sistematización de los fondos recuperados del año 1809, es indispensable contrastar estos datos con el catálogo manual existente en el actual A.D.P.Z. Por su parte, Máximo Pascual de Quinto, en su historia de la Real Maestranza zaragozana, utilizó varios registros de matrículas de insaculados procedentes del archivo del reino y conservados en el archivo de la Diputacion Provincial. ${ }^{24}$ El panorama de los archivos aragoneses trazado por Jiménez Catalán incluyó el archivo de la antigua Diputación del reino reproduciendo en buena medida los datos consignados por Ibarra. ${ }^{25}$

Ángel Canellas se ocupó de la transcripción de algunos de los documentos que formaron la llamada «alacena de Zurita», por conservarse allí

22 Eduardo Ibarra (1909-1910).

23 Esta circunstancia se muestra en el caso de los registros de ápocas de censales y los registros de ápocas de salarios, comisiones y consultas. El primer documento registra los pagos de intereses a los censalistas, y constituye un tipo documental ligado a la administración de la emisión y pago regular de los intereses de los censales cargados sobre las generalidades del reino. El segundo tipo documental consigna esencialmente los gastos que por orden de los diputados se hacían "para beneficio del Reino", además de aquellos gastos que quedaban regulados mediante consulta interpuesta ante la corte del Justicia de Aragón, según se recoge en el ordenamiento foral del reino.

24 Máximo Pascual de Quinto (1916), pp. 784 y ss.

25 Manuel Jiménez Catalán (1925b). 
el gran volumen documental que sirvió al historiador zaragozano para elaborar su ingente producción historiográfica. ${ }^{26}$ En realidad, los documentos de Zurita que se custodiaban en el archivo del reino de Aragón ocupaban nada menos que dos armarios, el 3 y el 4, bajo el rótulo "Papeles del secretario Zurita». Trabajos como los de Miguel de Manuel, ${ }^{27}$ Peter Rassow $^{28}$ y J. de Salas Bosch han permitido identificar un gran número de piezas documentales utilizadas por el cronista aragonés. ${ }^{29}$ También Canellas se ocupó de dar noticia de los documentos que se adquirieron por la Diputación Provincial de Zaragoza provenientes del archivo del reino. ${ }^{30}$ Asimismo, en la obra sobre los cronistas de Aragón de Cipriano Muñoz y Manzano, conde de la Viñaza, puede rastrearse un gran número de referencias a documentos referidos a Zurita conservados actualmente en la Real Academia de la Historia. ${ }^{31}$

Posteriormente, Castillo Genzor trazó una panorámica del contenido del archivo del reino de Aragón, en relación esencialmente con la documentación procedente de la corte del Justicia. ${ }^{32}$ Antonio Ubieto recogió los procesos procedentes de la Diputación, que actualmente se encuentran mezclados con los procesos inquisitoriales en el Archivo Histórico Provincial de Zaragoza. ${ }^{33}$ En relación con este archivo, con motivo de las Jornadas de Archivos Aragoneses del año 1981, Javier Cañada Sauras presentó una comunicación acerca de la documentación del Justicia conservada en el antiguo archivo de la Audiencia Territorial de Zaragoza, que en gran medida completa las noticias ofrecidas por Castillo Genzor, ${ }^{34}$ y en 1986 volvió a tocar el tema de la documentación judicial. ${ }^{35}$ Del mismo autor, es preciso destacar el trabajo acerca de las habilitaciones de infanzonía conservadas en el archivo de la Diputación Provincial de Zaragoza, procedentes del archivo histórico del reino de Aragón. ${ }^{36}$ Finalmente, Antonio Manuel

26 Ángel Canellas López (1959), pp. 231 y ss., (1969) y (1983).

27 Miguel de Manuel (1933).

28 Peter Rassow (1933).

29 J. de Salas Bosch (1944).

30 Ángel Canellas López (1968).

31 Conde de la Viñaza (1904), pp. 60-65.

32 Adolfo Castillo Genzor (1955).

33 Antonio Ubieto Arteta (1959).

34 Javier Cañada Sauras (1981).

35 Javier Cañada Sauras (1986).

36 Javier Cañada Sauras (1978b). 
Parrilla realizó el catálogo de los documentos del Justicia que procedían del archivo y de las escribanías del palacio de la Diputación, que actualmente pueden consultarse tanto en el archivo de la Diputación Provincial como en el Archivo Histórico Provincial de Zaragoza. ${ }^{37}$ A este trabajo debe sumarse el de Ana Ximénez de Embún, donde se incide en la documentación procedente de las escribanías del Justicia de Aragón que se custodia actualmente en este último archivo. ${ }^{38}$

De hecho, en el archivo de la Diputación Provincial se puede encontrar un importante número de procesos, sentencias, cartas y demandas, así como varios procesos de denunciación contra los lugartenientes de la corte del Justicia de Aragón, y también algunos libros del consejo del Justicia. Con respecto a los fondos de este tribunal, se ha subrayado que por acto de corte (1436) debían habilitarse dos archivos para custodiar tanto los fondos de la Diputación como los del Justicia y de la gobernación y hacienda regia. Esta circunstancia puede estar motivada por el hecho de que los procesos tramitados por esta corte se conservasen en las escribanías de dicha institución, ubicadas a su vez en las dependencias del palacio del reino.

Desde una perspectiva general, la documentación procedente de la Diputación del reino ha sido tratada en fecha más reciente por Domingo Buesa y Guillermo Redondo, ${ }^{39}$ así como por Ángel Canellas, aunque de forma limitada. ${ }^{40}$ También el profesor Enrique Solano repasa brevemente el contenido documental del antiguo archivo del reino, destacando el valor de algunos tipos documentales conservados para la investigación histórica. ${ }^{41}$

Los datos suministrados por el censo guía de archivos (http://www.mec.es) muestran una información similar a la aportada por la Diputación Provincial de Zaragoza (http://www.ebro.unizar.es), si bien los datos refereridos al fondo de la Diputación del reino de Aragón han sido recientemente reflejados en papel gracias al trabajo elaborado por la

\footnotetext{
37 Antonio Manuel Parilla Hernández (1991).

38 Ana Ximénez de Embún (1992).

39 Domingo Buesa y Guillermo Redondo Veintemillas (1979).

40 Ángel Canellas López (1981).

41 Enrique Solano Camón (1992).
} 
actual directora del archivo de la Diputación Provincial de Zaragoza, Blanca Ferrer, quien en colaboración con Alicia Sánchez Lecha ha dado a conocer los fondos que componen el archivo de la corporación provincial, donde se incluye el fondo procedente del archivo del reino. ${ }^{42}$

Los resultados alcanzados en esta investigación permitirán, en primer lugar, aumentar el conocimiento sobre las prácticas administrativas y archivísticas desarrolladas en Aragón durante la Edad Moderna. Además, las instituciones que custodian el fondo de la Diputación del reino de Aragón podrán controlar su documentación afianzando su gestión en el conocimiento explícito del sistema documental de la Diputación. Por su parte, archiveros y científicos de la Archivística tendrán la oportunidad de contrastar dichos resultados con los fundamentos y la metodología propuesta para la reconstrucción de fondos de archivo. Finalmente, los investigadores y usuarios de la información proporcionada por los documentos del antiguo archivo del reino de Aragón podrán completar su conocimiento del panorama documental desarrollado a lo largo de los siglos por la Diputación aragonesa. De igual modo, los investigadores centrados en el estudio de los modos de gestión, uso y conservación del escrito institucional en la Edad Moderna hispánica podrán complementar sus trabajos con alguna de las conclusiones referidas a los modos de producción y custodia desarrollados en el archivo del reino de Aragón.

Los resultados del trabajo de investigación sobre la producción y la custodia documental de la Diputación del reino de Aragón también se plantean en un próximo futuro como elementos básicos para acometer tareas de difusión de este fondo documental, que forma parte del archivo histórico de la Diputación Provincial de Zaragoza en la actualidad. En concreto, el mayor conocimiento del fondo del archivo del reino que resulte de nuestro estudio permitirá elaborar un proyecto coherente de descripción y digitalización de los documentos que incorpore la creación de un módulo de consulta de documentos digitalizados de acuerdo con criterios archivísticos, fundamental para su posterior difusión y recuperación vía web en una segunda etapa. Este proyecto de digitalización de toda la memoria documental del antiguo reino de Aragón parece tomar forma,

42 Blanca Ferrer Plou (1995) y Blanca Ferrer Plou y Alicia Sánchez Lecha (2000). 
según se desprende de las recientes noticias aparecidas en la prensa aragonesa. El área de cultura de la Diputación Provincial de Zaragoza se ha propuesto llevar a cabo la digitalización de todo el fondo de la Diputación del reino, si bien en varias fases. ${ }^{43} \mathrm{El}$ precedente más próximo lo constituye el proyecto de digitalización desarrollado sobre los fondos del archivo del reino de Valencia, con el resultado de tres volúmenes en CD-ROM con instrumentos de descripción, publicados por la Fundación Tavera. ${ }^{44}$

44 G. Almiñana y Carlos López Rodríguez (1997). 


\section{LA DIPUTACIÓN DEL REINO DE ARAGÓN}

\subsection{Fin y evolución histórica}

Como paso previo al análisis de la producción y custodia documental de una institución en el ejercicio de sus competencias y funciones, resulta imprescindible la caracterización de ésta, atendiendo tanto a la determinación de sus funciones, órganos y atribuciones específicas como al estudio de la evolución de estos elementos, de los que derivará todo el entramado administrativo de génesis y trámite documental. En suma, se trata de llevar a cabo las siguientes tareas para, en último término, identificar la estructura administrativa y funcional y con ello la naturaleza del organismo productor:

Análisis de la historia de la institución para identificar los límites del fondo y encuadrar la naturaleza de sus fines y la evolución de sus estructuras orgánica y funcional.

Identificación de cuantas leyes y normas determinen la estructura administrativa y sus funciones $y$ actividades.

Búsqueda y análisis de las normas de organización interna.

Búsqueda y análisis de manuales de procedimiento administrativo que fijan el proceso de toma de decisiones y determinan en última instancia la génesis documental. ${ }^{45}$

45 Miguel Ángel Esteban Navarro (1997). 
Para acometer esta tarea con respecto a la Diputación aragonesa, se cuenta con diversas aportaciones de los historiadores del derecho en general, y muy especialmente de los historiadores de las instituciones aragonesas, de las que ya dimos oportuna cuenta en la introducción. A partir de estos estudios, ensayaremos una definición de la Diputación aragonesa y un bosquejo de los principales hitos de su trayectoria histórica, con objeto de disponer de una adecuada base sobre la que sustentar nuestra investigación.

La Diputación del reino de Aragón nació a mediados del siglo XIV en el seno de un proceso que afectaría de manera desigual a los reinos de la monarquía hispánica, como continuación lógica de las sesiones ordinarias de las Cortes, para alcanzar su plenitud a lo largo de los siglos XV y XVI y comenzar la decadencia en el siglo XVII hasta su definitiva extinción en los albores del siglo XVIII. Por tanto, sería incauto pensar en una falta de evolución política y organizativa en tan extenso período de tiempo. Los vaivenes del reino en relación con la política exterior, sus oscilantes relaciones con el centro de la monarquía hispánica y las contradicciones internas a que se vio sometida la Diputación en función de la tensión originada por el particular ordenamiento jurídico foral aragonés frente al castellano, obligan a jalonar el análisis en varias etapas históricas. Sin embargo, no es nuestra pretensión una historia institucional ni tampoco estructurar de forma diacrónica el quehacer de una institución clave para el pasado aragonés.

El origen de las diputaciones, tanto en la corona castellana como en la aragonesa, aparece ligado indisolublemente a las Cortes de los diferentes estados componentes de la Monarquía y dentro del peculiar sistema parlamentario de cada territorio. ${ }^{46}$ Las Cortes medievales podían adoptar en sus sesiones diversos acuerdos de interés para la gobernación del reino, pero su función principal era votar y conceder subsidios al rey para que atendiera los gastos del Estado. ${ }^{47}$ Asimismo, las Cortes, como sistema parlamentario representativo de cada uno de los reinos, ejercieron una actividad legislativa, pero con desigual fuerza según fueran Cortes de la corona de Castilla o de la de Aragón. La representación, organización y atribuciones de las Cortes aragonesas han sido analizadas en su conjunto de

46 García de Valdeavellano (1986), pp. 476-477.

47 J. A. Escudero (1995), pp. 544-545. 
manera magistral por González Antón, mientras que el conocimiento de las Cortes durante la Edad Media y Moderna se debe esencialmente a los estudios de Esteban Sarasa, Leonardo Blanco y Enriqueta Clemente. ${ }^{48}$

A fin de velar por la correcta gestión de la ayuda pecuniaria ofrecida al monarca, y para vigilar el cumplimiento de los acuerdos globales nacidos en el seno de las Cortes, surgió un órgano, la Diputación, que actuaba desde el término de una sesión hasta el inicio de la siguiente, primero de modo ocasional y luego permanente. ${ }^{49}$ Tres fueron, por tanto, las características primigenias y generales de esta institución: finalidad específica, dependencia y permanencia. Rasgos que permiten definir las diputaciones de modo genérico como «órganos estamentales y permanentes que tienen como misión cumplimentar los acuerdos de las Cortes, especialmente en materia fiscal». ${ }^{50}$ Por su parte, Font Rius las caracterizó también globalmente como «organismos político administrativos surgidos hacia fines de la Edad Media en los distintos Reinos de la Corona de Aragón y también en Navarra, como una delegación o emanación de las respectivas Cortes, llegando a adquirir en ciertos casos un carácter representativo del país y de sus instituciones». ${ }^{51}$

No obstante, como apuntó Tomás y Valiente, las diputaciones de Cortes tuvieron desigual relevancia y peso político en los diversos reinos hispánicos, siendo mayores en los reinos de la corona aragonesa. De hecho, este autor subrayó el incremento en las competencias de estas instituciones en la corona de Aragón, y cómo, tras nacer con una mera atribución fiscal, evolucionó hasta convertirse en «un organismo rico y poderoso, $\mathrm{y}$ en él se fueron acumulando prerrogativas que acaso tiempo atrás gozaron los municipios pero que desde fines del siglo XV en adelante, se concentraron en ella, permitiéndole absorber la vida entera del reino y asumir su representación». 52

La Diputación castellana ha sido analizada en los últimos años por Juan Luis Castellano, ${ }^{53}$ que presenta una visión general, y por Margarita

48 L. González Antón (1978). E. Sarasa (1979). L. Blanco (1996). E. Clemente (1997).

49 J. A. Escudero (1995), p. 544.

50 J. Lalinde Abadía (1974).

51 Josep María Font Rius (1949).

52 F. Tomás y Valiente (1982), p. 46.

53 Juan Luis Castellano (1990). 
Cuartas, que identifica su núcleo administrativo y burocrático: los contadores-secretarios. Según Cuartas, los secretarios actuaron como fedatarios públicos encargados de levantar acta en las juntas de diputados y de llevar un control de ausencias, y fueron responsables de actividades administrativas como escribir los recados y despachos mandados por los diputados, tramitar los escritos llegados a la Diputacion y hacer peticiones y memoriales de los diputados a las diversas instancias del poder central. Fruto de estas actividades surgió una documentación que se conservó en el archivo de las "Cortes de los diputados». ${ }^{54}$ Más recientemente, la Diputación de las Cortes castellanas ha merecido la atención de José Luis Bermejo en un trabajo que analiza la evolución histórica de la institución. ${ }^{55}$

En el caso concreto de la corona de Aragón, la creación de las diputaciones fue simultánea en los reinos de Aragón y de Valencia y el principado de Cataluña, cuyo origen ha fechado Sesma en las Cortes de Monzón de $1362 .{ }^{56}$ La tradicional autonomía jurídica de la que gozaba cada uno de los territorios integrantes de la corona de Aragón tuvo en la creación de las tres diputaciones una de sus más genuinas expresiones. ${ }^{57}$ Esta circunstancia se extendería al campo de la custodia de los documentos emanados a su vez de cada una de las instituciones representativas del gobierno de dichos territorios, ya que cada diputación creó su propio archivo. No obstante, a pesar de la simultaneidad y concomitancias entre las diputaciones de la corona de Aragón, también sus diferencias constitutivas han sido elementos analizados recientemente. ${ }^{58}$

La Diputación del general de Cataluña ha recibido una especial atención por parte de los investigadores; el empuje definitivo ha provenido de

54 Margarita Cuartas Rivero (1991).

55 José Luis Bermejo Cabrero (1997).

56 J. Á. Sesma (1977), pp. 32-33.

57 Alejandro Abadía Irache (1993), pp. 32-37. Jesús Lalinde Abadía (1962).

58 Gregorio Colás Latorre (1998), p. 31: «Pero entre las tres diputaciones había diferencias. La aragonesa tenía ocho diputados. La catalana y valenciana seis cada una. Como en el resto de los cargos colegiados, el sistema utilizado para acceder a la condición de diputado era la insaculación [...] También las funciones o cometidos eran distintos. Las tres se ocupaban de gestionar la hacienda del reino, que tenía en las generalidades -impuesto sobre el comercio exterior- el recurso más importante, y de recaudar los servicios votados al monarca; pero, mientras la aragonesa y catalana tenían encomendada la defensa de los fueros y gozaban de la facultad de enviar cartas, representaciones y embajadas a la corte, la valenciana precisaba contar con los estamentos». 
la publicación de importantes series documentales generadas por la institución. A los trabajos clásicos de De la Torre y del Cerro o de Rubió y Cambronero ${ }^{59}$ deben sumarse los más recientes de Víctor Ferro, ${ }^{60}$ María Teresa Ferrer i Maillol, ${ }^{61}$ quien ha trazado una panorámica global de la institución, y Miquel Pérez Latre. ${ }^{62}$ Con posterioridad a estos trabajos, Capdeferro y Plá ha analizado la función de los asesores de dicha institución durante el siglo XVII, estudio necesario para consolidar el conocimiento de algunas series documentales generadas por la Diputación catalana. ${ }^{63}$ Por su parte, Sánchez de Movellán se ha ocupado de analizar una tipología documental tan necesaria para determinar las estructuras orgánicas y funcionales de la Diputación como son las ordinaciones constitucionales de 1432. ${ }^{64}$ Todos ellos han desarrollado con mayor o menor intensidad un análisis de la estructura y el funcionamiento de la institución, elementos esenciales para comprender los mecanismos administrativos y documentales desarrollados en su seno. En estos estudios existen diversas alusiones al archivo de la Diputación catalana, si bien todavía falta un trabajo exclusivo sobre el particular. ${ }^{65}$ No obstante, Sans i Travé ofrece una interesantísima contribución al conocimiento de la producción documental de la Diputación de la generalidad catalana, mostrando sus principales series. ${ }^{66}$ Es precisamente la monumental serie de Dietaris de la Diputació una de las que mayor atención recibe, fruto sin duda de una decidida política editorial de exhumación de fuentes documentales históricas esenciales para reconstruir el pasado catalán, ya que recoge numerosas noticias de muy diversa índole desde 1411 hasta la llegada de la Nueva Planta. ${ }^{67}$ En estos Dietaris se encuentra la memoria documentada de los actos cotidianos, anotados diariamente, por lo que constituyen un magnífico ejemplo de constancia administrativa institucional que permite disponer de una información excepcional para analizar los modos de producción y custodia documental de la citada institución.

\footnotetext{
59 A. de la Torre y del Cerro (1923). Ignacio Rubió y Cambronero (1950).

60 Víctor Ferro (1987) y (1997).

61 María Teresa Ferrer i Maillol (1991).

62 M. Pérez Latre (1993) y (1996).

63 Josep Capdeferro i Plá (1997).

64 Isabel Sánchez de Movellán Torent (1997).

65 Ignacio Rubió y Cambronero (1950), pp. 308-311.

66 J. M. Sans i Travé (1998), pp. 203-212.

67 J. M. Sans i Travé (dir.) (1994-1996).
} 
Con respecto a la Diputación del reino de Valencia, sucede algo parecido a la Diputación catalana. Existen varios trabajos de naturaleza institucional y otros sobre el propio archivo de la generalidad del reino valenciano. ${ }^{68}$ Se debe destacar que, al igual que sucede en el archivo del reino de Aragón, el archivo del reino de Valencia contaba con una separación de los fondos documentales producidos por instituciones diferentes, que se custodiaban en estancias separadas de un mismo edificio, como apunta Carlos López. ${ }^{69}$ Este dato ejemplifica una vez más la práctica separación de fondos siglos antes de la formulación científica del principio de procedencia en el XIX.

Centrándonos en la Diputación del reino de Aragón, su origen se encuentra, al igual que las diputaciones del resto de la corona y de otras instituciones que surgen en la misma época en distintos países europeos, en la necesidad de contar con un organismo ocupado de la gestión del monto pecuniario ofrecido al monarca por las Cortes. ${ }^{70}$ Llegados a este punto, las Cortes de Teruel de 1427 y las de Monzón en 1436 otorgan carta de naturaleza a la institución, que definitivamente se erige como un poder autónomo de las reuniones de Cortes. ${ }^{71}$ Poder que encontraría el motivo de su perduración temporal en la administración de un nuevo tributo, el impuesto de las generalidades, consistente en la recaudación aplicada a los conceptos industriales (fabricación), comerciales (tráfico de mercancías que entran o salen de las fronteras del reino) y asociativos (cofradías y gremios). ${ }^{72}$ Este nuevo gravamen se entendió como alternativa al tradicional sistema fiscal basado en la distribución por brazos y en el reparto por fuegos, considerados según Sesma arcaicos «en una sociedad cuyo desarrollo de las actividades urbanas y mercantiles permitía ya unos contrastes de ingresos y posibilidades muy marcados entre las diversas clases de la población». ${ }^{73}$

68 J. Camarena (1955). J. Martínez Aloy (1930). M. R. Muñoz Pomer (1987). Rafael Conde y Delgado de Molina (1994-1995). Guía del Archivo del Reino de Valencia (2000), pp. 39-42.

69 Carlos López Rodríguez (1996), p. 176, nota 1, y (1997).

70 L. González Antón (1978), p. 130.

71 Ibídem, p. 31: «El nacimiento de la Diputación aragonesa, [...] hay que buscarlo en las Cortes. Sus inicios son, simplemente, el constituir una prolongación de las reuniones de los brazos para resolver un asunto que, por su larga duración, excede el tiempo de funcionamiento de la asamblea. [...] La evolución que experimenta la Diputación [...] le hace ir independizando su actuación [...]».

72 Véanse al respecto los trabajos de Sesma (1976), (1979) y (1983).

73 Sesma y Armillas (1991), pp. 20-21. 
Este impuesto fue la base de la hacienda del reino de Aragón y del sostenimiento económico de la Diputación, que invirtió los beneficios económicos obtenidos en numerosos frentes. Entre los más notables se halla el programa institucional de conservación de los documentos del reino, junto con la organización y custodia del resultado de la política editorial patrocinada por la Diputación con las repetidas ediciones de fueros y crónicas de Aragón. La independencia que la gestión de este impuesto proporcionaba al reino ya la remarcó el abogado fiscal Juan Pérez de Nueros, quien en 1577 elaboró una obra de síntesis acerca de la administración de justicia en Aragón y otras cuestiones institucionales, entre las que sobresalía la caracterización política de este impuesto. ${ }^{74}$

Una vez consolidada la posición de la Diputación en el entramado del reino y convertida en el siglo XV en el intermediario obligado en la relación entre éste y la Monarquía, esta institución no fue ajena a la asunción de competencias tanto de gobierno como de naturaleza económica y hasta judicial. Así, tras una primera etapa en su evolución competencial marcada por la responsabilidad fiscal, desplegaría su acción a lo largo de su andadura histórica en cinco grandes áreas, según su principal estudioso: representación estamental permanente, para la que contaba con una estructura fija de ocho diputados (dos por cada brazo estamental); intervención en los asuntos internos y externos que afectaban al reino, como la defensa de fronteras, la imposición de treguas, la regulación de la carestía de alimentos, etc.; gestión de diversos asuntos fiscales, económicos, políticos y administrativos; actuación como delegación de las Cortes, entendida como prolongación de las reuniones de los brazos para solven-

74 Juan Pérez de Nueros [abogado fiscal del señor rey Felipe II], Sumaria noticia de algunas cosas del Reino de Aragón, [1577], B.N.E., ms. 1894, f. 14v: "Estas generalidades del Reyno, son cierto derecho que por acto de corte está ympuesto sobre las mercaderías que salen del Reyno y entran en él, el qual se rige y administra por ocho oficiales, que se dicen los diputados del Reyno, que cada un año salen por suertes, dos de cada brazo estado; y los dichos derechos sirven para utilidad del Reyno, para emplearlos y gastar las pensiones de los censales que están cargados sobre el Reyno, salarios de oficios y otras cosas en que se pueden y deben gastar conforme a lo que por fueros y actos de corte está ordenado; sin que el Rey ni sus oficiales se puedan intrometer en la administración, ni otra cosa alguna tocante a las generalidades. [...] y así, esta manera de generalidades es de grande importancia, y la mayor fuerça que ay en el Reyno para defender y conservar los fueros y libertades de aquél y para gastar todo lo que conviene para el beneficio público y universal del Reyno». 
tar asuntos no resueltos en las sesiones ordinarias por su larga duración; y, por último, vigilancia del cumplimiento de lo dispuesto en el ordenamiento jurídico aragonés. ${ }^{75}$

De acuerdo con estos rasgos, la Diputación del reino de Aragón ha sido definida por Sesma como aquel «organismo con representatividad estamental permanente, de carácter fiscal, político y administrativo, tanto en asuntos internos como externos al Reino, cuya autoridad emana de las Cortes y su actuación está basada en cumplir y hacer cumplir los fueros y libertades del Reino, sirviendo de nexo en las relaciones entre éste y el rey». ${ }^{76}$

De todas esas funciones, progresivamente adquiridas a lo largo de los años, se derivó una actividad administrativa que tuvo su lógico reflejo en los mecanismos de producción y de custodia documental, cuya organización revirtió evidentemente en beneficio de la gestión interna de la institución, pero también actuó como un elemento clave en las denominadas «estrategias de la memoria» desarrolladas por el poder. Mantener ordenadas y accesibles las escrituras del reino posibilitó el ejercicio adecuado de las funciones de la Diputación. En última instancia, el sustrato sobre el que se apoyaban decisiones y acciones lo constituía el conjunto de actividades de génesis, tramitación, organización y consulta de las escrituras y documentos custodiados en el archivo del reino de Aragón situado en el palacio de la Diputación. Recinto en el que también se custodiaban documentos generados por la Audiencia Real y por la corte del Justicia y, a partir del siglo XVIII, los de bailía y maestre racional, que, aun albergados en un mismo edificio, se hallaban en distintas estancias, de modo que sus fondos documentales se encontraban perfectamente delimitados y separados de los producidos por la Diputación del reino.

Es indudable que el reino de Aragón, desde mediados del siglo XV, conformaba una entidad sociopolítica regida por un ordenamiento jurídi-

75 Sesma (1977), p. 30.

76 Sesma (1977), p. 31. No obstante, el mismo autor precisa que «Aunque las manifestaciones de los componentes de la Institución a lo largo del siglo XV, inciden en hacerse representantes del reino en su conjunto, es decir, en afirmar que actúan "en nombre y voz de todo el regno", que sus decisiones las toman "por nos, si quiere por el dicho reyno y quatro braços de aquel”, el carácter estamental del organismo y la aplicación práctica de sus medidas, viene a demostrar que la Diputación es un organismo de presión de determinados grupos constitutivos de una minoría». 
co notoriamente diferente del vigente en Castilla, caracterizado por el hecho de que, como afirma Jesús Delgado, «Aragón no se rige como los otros reinos, sujetos sin más arbitrio del gobernante. Aquí hasta el rey se sujeta a las leyes [...] de modo que reinar es más difícil, pues han de guardarse las libertades del Reino [...] En Aragón, a diferencia de en Castilla, el rey no es absoluto: "a legibus solutus", superior a las leyes y desligado (solutus) de ellas». ${ }^{77}$ Quedaban de este modo definidas dos modalidades distintas de relación política en la España moderna: el decisionismo jurídico castellano y el normativismo historicista catalano-aragonés. ${ }^{78} \mathrm{La}$ existencia de instituciones privativas del reino (esencialmente las Cortes, su delegación representada por la Diputación como defensora permanente de los fueros y libertades del reino y, finalmente, la corte del Justicia) reforzaba además las diferencias, favoreciendo la toma de conciencia sobre la particularidad de Aragón frente al resto de España.

La existencia de esta realidad jurídica, junto con el hecho de que la Diputación se ocupara de asuntos de gobierno del reino, condujo a que esta institución se convirtiera, tras la llegada de la dinastía de los Austrias, en el adalid de una posición denominada «defensiva» del particular ordenamiento jurídico aragonés frente a una Monarquía deseosa de reducir homogéneamente al reino. ${ }^{79}$ Así, encabezó la resistencia del reino apelando a una reivindicación del derecho de naturaleza consuetudinaria y a la tradicional identidad de Aragón en el conjunto de los reinos peninsulares, que se manifestaba en la fórmula de equilibrio representada por el «pactismo». ${ }^{80} \mathrm{El}$ reino había tenido tensiones previas por estos motivos con Fernando II, por asuntos como la introducción del Santo Oficio en Aragón o la reforma (reparo) de la Diputación del reino llevada a cabo a fines del siglo XV. ${ }^{81}$

Sin embargo, los intentos de la Monarquía por limar de forma más o menos progresiva las competencias adquiridas por la Diputación del reino de Aragón no se hicieron efectivos hasta las Cortes de Tarazona de 1592,

\footnotetext{
77 Jesús Delgado Echeverría (1997), p. 101.

78 J. Lalinde Abadía (1966). Recogido por J. Gil Pujol (1991a), p. 306.

79 José Ángel Sesma y J. A. Armillas (1991), p. 47: «La defensa institucional del orden establecido".

80 Vid. Javier Gil Pujol (1978). Jesús Lalinde Abadía (1980).

81 José Ángel Sesma (1987b).
} 
epílogo de las «alteraciones de Aragón de 1591», ${ }^{82}$ para terminar finalmente con la propia disolución de la institución en 1708 con los Decretos de Nueva Planta. ${ }^{83}$

Hasta entonces, la defensa del ordenamiento foral aragonés y la necesidad de su respeto por el rey fueron argumentos continuamente esgrimidos por las instituciones aragonesas ante las absolutistas y uniformizadoras pretensiones desplegadas por el gobierno de la Monarquía. ${ }^{84}$ Frente a los intereses de la Monarquía y las posibles vulneraciones del estatus jurídico producidas en el seno del reino por cualquier persona, la Diputación esgrime con fuerza el recurso a las libertades del reino, simbolizadas y sistematizadas en el ordenamiento jurídico foral aragonés. ${ }^{85}$ Con tal motivo, son frecuentes las expresiones: "Y que así el Reyno devía salir a la defensa de ello, por precisa obligación de defender los fueros», ${ }^{86} \mathrm{o}$ "Los dipputados del reyno de Aragón, atendientes e considerantes que por fueros, actos de Cort e ordinaciones del dicho reyno pertenesca defender los fueros e libertades

82 Para el estudio de la revuelta aragonesa, es imprescindible la consulta como obra de referencia del trabajo de Jesús Gascón Pérez (1995). Las Cortes de Tarazona de 1592 no suponen, a juicio de Javier Gil Pujol, un punto de inflexión en las particulares relaciones entre rey y reino. Más bien hay que entenderlas como la intervención, a través del parlamento aragonés legítimamente constituido, del monarca en su intento de reordenar la situación política tras los graves sucesos de 1591: «Es precipitado, por lo tanto, afirmar — como se ha hecho tan a menudo- que los años 1591-1592 marcan el fatídico declive de la foralidad aragonesa y con ella el de las Cortes del Reino» (Gil Pujol, 1991a, p. 315). Vid. Enrique Solano Camón (1992), p. 377: «Los intentos reformadores de Fernando el Católico, unidos a las fricciones jurisdiccionales de la etapa carolina, así como la presión políticomilitar ejercida por Felipe II —propiciadora de las denominadas «alteraciones aragonesas», que afectarían la vida del Reino en la segunda mitad de la centuria, derivando finalmente en las reformas de la "constitución» aragonesa, acordadas en las cortes celebradas en Tarazona en junio de 1592 - no llegarían a extinguir la personalidad del viejo Reino, si bien quedaría ésta sustancialmente mermada».

83 Antonio Peiró Arroyo (1988).

84 Jesús Delgado Echeverría (1997), pp. 100-101: «Los extranjeros de la época se sorprenden de las trabas que a la monarquía absoluta oponen las libertades aragonesas».

85 José Ángel Sesma (1977), p. 31: «Vigilancia y cumplimiento de fueros y libertades del reino. De todos los puntos tratados hasta ahora, se deduce que la Diputación ciñe su actuación a lo establecido por los fueros privativos del reino y defiende los abusos que contra ellos se cometen, provengan de donde provengan. Precisamente, las manifestaciones de los propios diputados hacen referencia a ello, pues centran la finalidad de la institución en la "custodia y guarda de los fueros y libertades deste reyno"".

86 Lorenzo Ibáñez de Aoiz, Ceremonial y breve relación..., B.N.E., ms. 2992, f. 357v. 
del dicho reyno...». ${ }^{87}$ Como señala Sesma, los diputados «se consideran defensores del bienestar del Reino de los regnícolas, pues para ellos, "al officio nuestro incumbe quitar todos agravios y danyos del reyno de Aragón y de los regnícolas de aquél" [...] su objetivo final es el "bien e utilidat del dicho reyno e de la cosa pública et de los vezinos et habitantes en aquel"». ${ }^{88}$

Simultáneamente, entre los juristas y cronistas aragoneses de la Edad Moderna (especialmente Blancas en sus Comentarios de las cosas de Aragón) surge una reflexión mitificadora de las libertades del reino y de su preponderancia frente a cualquier otro poder ${ }^{89}$ De este modo, el pactismo terminó convirtiéndose en una filosofía política que con su apelación a las tradicionales libertades del reino intentaba defender una forma de gobierno para Aragón cuyo elemento definidor era el respeto del rey a las libertades y a su ordenamiento foral. ${ }^{90}$ El pactismo, asentado en la afirmación de la particularidad político-jurídica de Aragón dentro de la monarquía hispánica, hacía de las Cortes y del Justiciazgo los dos valladares del reino frente a unos monarcas de quienes se recelaban oscuras intenciones, alimentadas por su alejamiento físico y por la que parecía evidente falta de sensibilidad en la gobernación de Aragón». ${ }^{11}$

Sin embargo, no se debe interpretar el pactismo únicamente como una cultura del enfrentamiento, pese a su creciente ideologización a lo largo del siglo XVI, pues se trataba también del intento de mantener un entendimiento necesario o, más correctamente, una colaboración vigilante entre el monarca y el poder del reino a través del foro tradicional de decisiones que regulaban esta relación secular, las Cortes aragonesas. ${ }^{92}$

87 Registro de actos comunes de la Diputación del reino (1498), A.D.P.Z., ms. 86, f. 46r. Publica J. Á. Sesma (1977), p. 454.

88 J. Á. Sesma y J. A. Armillas (1991), p. 47.

89 Jerónimo de Blancas, Aragonensium rerum commentarii, Zaragoza, Laurentius Robles et Didacus Fratres, 1588. La obra fue traducida por Manuel Hernández, Zaragoza, Diputación Provincial, 1878; de esta versión hay ed. facs. a cargo de Guillermo Redondo Veintemillas y Esteban Sarasa Sánchez, Zaragoza, Cortes de Aragón, 1995.

90 M. Danvila y Collado (1881). Jesús Lalinde Abadía (1972-1973). J. Gil Pujol (1991a).

91 J. Gil Pujol (1991a), p. 306.

92 J. Gil Pujol (1991a), pp. 304-305: «El binomio rey-reino o rey-Cortes se solía entender, también para el caso aragonés, según una óptica liberal decimonónica que lo plantea ante todo en términos de enfrentamiento. La idea vigente, en cambio, era la de que 
Pero tampoco se debe olvidar que tras la defensa del pactismo se hallaba asimismo el intento de preservar inmutable un ordenamiento foral que era la base legal que afianzaba los privilegios de la elite rectora del reino, representada por el consistorio de los diputados. ${ }^{93}$

Todo lo anterior, unido a la preponderancia de Castilla en el proyecto de monarquía universal de los Austrias, favoreció que la Diputación tuviera como una de sus funciones más importantes la defensa de las particularidades del reino de Aragón. Esto le sirvió indudablemente para «asegurar su hegemonía en el interior y frenar cualquier intento de alteración proveniente del exterior, incluyendo en ello al rey. La Diputación, al recibir la encomienda de velar por la conservación de Fueros, Libertades y Privilegios, se convierte prácticamente en el símbolo del reino, del conjunto de aragoneses». ${ }^{94}$ De este modo, los aragoneses se encontrarán sujetos y a la vez amparados por esa reunión simultánea de poder político, fiscal y simbólico que consiguió la representación del reino. ${ }^{95}$

Desde la todavía precaria Diputación nacida a mediados del siglo XIV hasta la poderosa institución consolidada en la segunda mitad del XV y su final disolución, registrada en los albores del siglo XVIII, la Diputación aragonesa atraviesa una serie de avatares que corren paralelos a la propia historia del reino de Aragón. En la segunda mitad del siglo XV se asiste a la consolidación institucional definitiva, delimitando su estructura, sus atribuciones, su organización administrativa y su memoria escrita. Sin embargo, la reorganización aplicada por Fernando II, conocida como reparo del

uno y otro debían colaborar armónicamente, pues constituían los sujetos esenciales de la maquinaria de gobierno. [...] Es decir, el dualismo se resolvía, debía resolverse, en unidad de acción para el bien común bajo batuta real. [...] En Aragón, además, al igual que les sucedía a los otros territorios de su Corona, se dio la importante circunstancia adicional de la que sería definitiva partida del monarca del reino. Autoritarismo y absentismo iban a repercutir necesariamente en las relaciones del rey con los brazos y, por consiguiente, en la vida política aragonesa. A causa de ello, los brazos adquirieron paulatinamente un papel orientado ante todo a la defensa del ordenamiento tradicional autóctono ante las novedades, reales o supuestas, buscadas por la corona. Consiguientemente, todo lo relativo a las Cortes, empezando por la misma frecuencia de convocatorias, que disminuyó, se vio rodeado de la máxima expectación».

93 Leonardo Blanco Lalinde (1996), p. 27.

94 J. Á. Sesma y J. A. Armillas, en su introducción a la obra de Lorenzo Ibáñez de Aoiz, Ceremonial y breve relación..., p. 21.

95 J. A. Armillas y E. Solano (1992). 
general, constituye uno de los primeros ajustes institucionales de gran calado. Durante el siglo XVI, el peso específico de la función política lleva a la Diputación del reino a abanderar la defensa del ordenamiento jurídico aragonés, desarrollando una política reivindicativa frente a la monarquía, aunque trágicamente cercenada a consecuencia de la rebelión de 1591. A partir de este momento, la defensa empecinada de dicho ordenamiento se trastoca en un mayor acercamiento a la monarquía y en una notable labor de imagen, tendente, por una parte, a garantizar la adhesión sin fisuras del reino al monarca y, por otra, a lavar la imagen de la institución tras los acontecimientos de 1591. Sin embargo, los propios derroteros seguidos por la monarquía durante el siglo XVII arrastran inevitablemente a la propia Diputación, ofreciendo un panorama dominado por las prestaciones hechas por el reino de Aragón a la Monarquía y el progresivo debilitamiento de la Diputación del reino. ${ }^{96}$ En el último tercio del siglo XVII se asiste a un proceso de revitalización de la postura defensora del foralismo («reacción parlamentaria aragonesista [...] en el que se inició un movimiento fuerte de examen interno, constituyéndose una junta - La Junta Magna - con el fin de estudiar los procedimientos para reactivar la vida económica y sacar al país de su lenta agonía»), que tuvo como figura catalizadora a Juan José de Austria. ${ }^{97}$

El progresivo desgaste de las instituciones aragonesas que hundían sus raíces en la Edad Media discurrió paralelo a la transformación política que tendría su final consecuencia en el cambio dinástico en la Corona de la monarquía hispánica. Así, las repercusiones del conflicto que enfrentó al candidato borbónico y al Habsburgo tuvieron en el reino de Aragón una profunda incidencia. Supuso el triunfo de una voluntad reformista de la situación de los reinos hispánicos guiada por el espíritu de uniformidad y centralización absolutas de los territorios en los órdenes políticos, económicos y administrativos. En el plano institucional y jurídico, la consecuencia inmediata del ascenso al trono de Felipe V, IV de Aragón, fue la supresión efectiva de los fueros, privilegios, usos y costumbres políticos y administrativos de los reinos de la corona de Aragón, lo que venía a suponer a efectos prácticos la extinción de las instituciones que habían regido

96 Enrique Solano Camón (1987).

97 J. A. Armillas (2000), p. 77. 
el panorama político, administrativo y judicial aragonés durante más de trescientos cincuenta años.

El comienzo del proceso desintegrador se inicia en Aragón en 1705, con el alzamiento en armas de algunas zonas del reino contra Felipe de Anjou en favor de Carlos de Habsburgo. La batalla de Almansa (1707) se saldó con victoria borbónica, lo que permitió al futuro monarca la derogación del ordenamiento jurídico del reino de Aragón mediante pragmática dada en el Buen Retiro, moderada por Real Decreto de 29 de junio de 1707. ${ }^{98}$ No terminarían aquí los avatares sucesorios y sus repercusiones para el reino aragonés, pues la victoria militar del archiduque don Carlos de Habsburgo en Almenara y Zaragoza en 1711 propició que se restablecieran los fueros en dicho año. Sin embargo, la final victoria de Felipe de Anjou en 1713 acabó por imponer la voluntad centralizadora de la Monarquía borbónica.

La primera repercusión institucional del triunfo borbónico fue la efectiva desaparición, el 15 de julio de 1707, del Consejo de Aragón, máximo órgano consultivo del rey para solventar los asuntos relacionados con los reinos de la corona aragonesa. ${ }^{99}$ Simultáneamente, el virrey aragonés fue sustituido por el capitán general, que a su vez poseía el cargo de presidente de la Audiencia. Por su parte, el intendente de Zaragoza, con funciones relativas a la administración militar, amplió sus prerrogativas al ámbito económico y fiscal como funcionario de la Hacienda regia y encargado de la recogida de impuestos, rentas reales y conocimiento de los recursos económicos del territorio aragonés. El hecho de que su sede estuviera en Zaragoza propició que también el intendente fuese el regidor de la ciudad, con lo que se concentraban en una única persona el gobierno de la ciudad y las atribuciones económicas y militares al servicio del monarca en todo el reino.

Para el caso que nos ocupa, la consecuencia más relevante del advenimiento de la dinastía Borbón fue la supresión de la Diputación del reino de Aragón, cuyo funcionamiento cesaba a comienzos de 1708. Antonio Peiró data la final disolución del consistorio entre los días 11 de enero y 15 de febrero de 1708, si bien la abolición de los fueros de Aragón se había producido el 29 de junio de 1707. Así, el citado autor nos aclara cómo «el

98 Jesús Morales Arrizabalaga (1986).

99 Vid. Jon Arrieta Alberdi (1994), pp. 207-215. 
decreto de abolición de los fueros creó un nuevo modelo político de breve vigencia. El ordenamiento jurídico aragonés quedaba suprimido en su totalidad, pero algunas instituciones seguían existiendo. Así ocurría con la Diputación, que - como veremos- permaneció durante varios meses, representando la voluntad del Reino». ${ }^{100}$ Los diputados elegidos para este último y efímero ejercicio de la Diputación realizaron el 30 de agosto de 1707 lo que es considerada la última actividad de la Diputación del reino: la confección «del memorial de súplica por la abolición de los Decretos de Nueva Planta». ${ }^{101}$ Como acto visible del desmantelamiento de la institución que había regido el destino del reino de Aragón desde el siglo XV, por una orden de 25 de febrero de 1708 el marqués de Grimaldo, gobernador del Consejo de Castilla, obligaba a recoger las alhajas pertenecientes a la Diputación. ${ }^{102}$

Las funciones anteriormente desempeñadas por el consistorio aragonés fueron parcialmente asumidas por la recién creada Junta del Real Erario o Junta del Real Patrimonio, presidida por el propio comandante general que estaba al frente de la Audiencia Real, implantada en Zaragoza desde el 3 de abril de 1711. ${ }^{103}$ Esta junta estuvo supeditada al Consejo de Hacienda de la Audiencia y estaba compuesta por un presidente (el príncipe T'Serclaes de Tilly, comandante general del reino), dos eclesiásticos, dos nobles y dos ciudadanos, lo que significaba, como se puede observar, una simplificación no sólo de la composición de la antigua Diputación, sino también de sus funciones. ${ }^{104} \mathrm{~A}$ esta junta se incorporó el futuro intendente de Hacienda y fiscal general de Felipe V don Melchor de Macanaz,

\section{Antonio Peiró Arroyo (1988), pp. 14-16.}

101 Las circunstancias que rodearon a la extinción de la Diputación del reino, así como la composición del último consistorio (11 de junio de 1707), han sido descritas por Antonio Peiró Arroyo (1988), pp. 12-13. También en J. Á. Sesma y J. A. Armillas (1991), pp. 163-165.

102 Antonio Peiró Arroyo (1988), p. 20. Vid. con más detalle el inventario de las citadas alhajas, fechado en 1707 y actualmente conservado en el A.D.P.Z., leg. 755-5: «Alhajas que tenía el Consistorio de la Diputación al tiempo de su extinción en 1707 y destino de se les dio en 1708». Vid. además Ana Ximénez de Embún (1995).

103 Don Melchor de Macanaz (1879), p. 184: «Y es de advertir, que aunque venciesen al Rey a que formase la referida Junta, dudó muchos días el nombre que le había de dar. No quería que se llamase Diputación del Reino, ni Junta de la Diputación, porque éste era el nombre que los fueros le daban; Consejo de Hacienda tampoco, ni Junta de ella; y en fin, después de muchos días y de haber buscado nombres y más nombres, resolvió que se nombrase así: Sala, Junta o Tribunal del Real Erario».

104 Carmen Martín Gaite (1975), pp. 186-191. J. Á. Sesma y J. A. Armillas (1991), pp. 250-252. 
en un principio como simple "cobrador de rentas». ${ }^{105}$ Sin embargo, las tareas iniciales de reorganización fiscal del reino llevadas a cabo por la administración borbónica fueron diseñadas por Tomás Moreno Pacheco, cuyo relevo tomaría el citado Macanaz. ${ }^{106}$

\section{2. Órganos}

La aplicación de la metodología propuesta para el conocimiento de la producción documental de la Diputación del reino de Aragón y para la reconstrucción del orden original de los documentos obliga a sistematizar los componentes necesarios en todo sistema de producción y génesis documental en una institución. Estos componentes son los fines a los que obedece la existencia de la institución, que se precisan en funciones o atribuciones, para cuyo ejercicio la institución se dota de una estructura de órganos burocráticos de decisión y de gestión a través de los cuales obra y se manifiesta. Éstos originan una actividad administrativa, sujeta a unas normas, que se desarrolla mediante una serie de trámites plasmados finalmente en documentos. En consecuencia, una vez conocidos los fines y la historia de la Diputación aragonesa, se deben delimitar y analizar los órganos, las funciones y el procedimiento administrativo seguido, para culminar en la identificación de las series documentales mediante el análisis de las tipologías documentales generadas en el transcurso de su evolución histórica.

Como indica Baena del Alcázar, toda organización administrativa es susceptible de análisis desde una visión estática, referida a su estructura interna y centrada en los elementos actuantes, y otra dinámica, enfocada hacia las relaciones entre estos elementos orgánicos y las actuaciones que desarrollan, formalizadas en los llamados principios de organización.

Desde una perspectiva estática, el órgano es cada uno de los elementos de que se compone la totalidad de la organización: toda organización está

105 Carmen Martín Gaite (1975), p. 187.

106 Jesús Maiso y Rosa M.a Blasco (1984), p. 16: «El 27 de agosto de 1707 entraba en Zaragoza el superintendente general de las finanzas en Aragón, Thomás Moreno Pacheco. La superintendencia es la institución clave para la creación de nuevas imposiciones y para su control exclusivo y directo por parte de la corona. Moreno Pacheco introdujo el papel sellado, puso bajo su control las aduanas y el monopolio del tabaco —anteriormente administrados por la Diputación del Reino-, y se encargó del estanco de la sal». 
formada por una agrupación de órganos regidos según un orden. ${ }^{107}$ No obstante, resulta más preciso, y también más apropiado a nuestro objetivo, analizar el órgano como el conjunto de posibilidades de actuación de que es titular una o varias personas físicas. ${ }^{108}$ Por consiguiente, se puede definir un órgano político o administrativo como la unidad diferenciada del aparato decisorio o administrativo, respectivamente, de una institución, a la que se atribuyen un conjunto de funciones para su resolución o gestión. El órgano se configura, jurídicamente, por unas normas reguladoras, un conjunto ideal de atribuciones, unos medios naturales y financieros para su cumplimiento y un titular (unipersonal o colegiado), que es la persona cuya voluntad se imputa al órgano. Los titulares de los órganos de una institución y el personal a su servicio forman la burocracia de esa institución: el conjunto de empleados encuadrados en una jerarquía y repartidos por su territorio de actuación, donde las competencias de cada empleado, el nivel jerárquico que ocupa y el procedimiento que debe seguir para la gestión de los asuntos que le corresponden están delimitados y regulados.

La reflexión sobre las posibilidades de actuación de un órgano introduce la perspectiva dinámica, que se concreta en un doble análisis: por una parte, del principio o principios de organización que rigen la creación y el funcionamiento de la estructura orgánica de la institución; y, por otra parte, del contenido y el carácter de las funciones y las competencias que se atribuyen a los órganos, comprendidos en su contexto histórico de actuación.

La Diputación del reino de Aragón, como institución dotada de un importante núcleo administrativo y burocrático necesario para la consecución de los fines delimitados en la compilación foral aragonesa, permite su estudio en función de dos parámetros administrativos. Estudio que, de acuerdo con lo expuesto, se debe efectuar teniendo en cuenta el marco más general en el que se produce el desarrollo de la administración pública en el Antiguo Régimen, ligado a la aparición del Estado moderno, más en concreto durante los siglos XV a XVII, ya que sus rasgos se manifestarán, con carácter determinante, en la propia organización y funcionamiento de la Diputación. En este sentido, destacan los dos fenómenos siguientes.

107 Mariano Baena del Alcázar (1990), p. 72.

108 Luis Cosculluela Montaner (1995), pp. 166-173. Eduardo García de Enterría y T. R. Fernández (1990), pp. 527-528. 
En primer lugar, la afirmación del poder monárquico, y la consiguiente formación y continua ampliación de una administración propia de la Corona, que se produce durante esos siglos, no supuso ni la desaparición de unidades políticas menores con sus poderes feudales, como municipios y señoríos, ni el fin de los antiguos reinos o principados que componen el diverso y amplio espacio de las grandes monarquías, ya que, con frecuencia, conservaron sus ordenamientos jurídicos particulares y las instituciones que de ellos derivaban, como fue el caso de los territorios de la ya extinta corona de Aragón. Por el contrario, como sucede en el reino de Aragón, la Diputación, nacida como prolongación de las sesiones de Cortes con una atribución primigenia de naturaleza fiscal, no sólo mantuvo esta función, sino que las necesidades de afirmar el poder institucional aragonés frente a la Monarquía y de gestionar nuevas realidades surgidas del desarrollo económico, le llevaron a dotarse de otras funciones y, en consecuencia, a ampliar, consolidar y mantener una compleja estructura de órganos administrativos.

Y en segundo lugar, durante el Antiguo Régimen se asiste a la definitiva constitución de las organizaciones administrativas de acuerdo con el principio de jerarquía, por el cual una organización se vertebra en órganos subordinados entre sí que basan sus relaciones en la obediencia a los titulares de los órganos en función de normas reglamentarias. El principio de jerarquía supone la ordenación de los órganos en una gradación sucesiva de arriba abajo, que se traduce, por una parte, en una distribución de competencias en función de la posición de cada órgano en la estructura jerarquizada y, por otra parte, en la atribución de poderes de dirección de los órganos superiores sobre los inferiores dentro del marco de las relaciones funcionales. El principio de jerarquía se concreta en la existencia de tres potestades de los órganos superiores sobre los inferiores: potestad de dirección, que supone el poder de dictar órdenes concretas e instrucciones generales de obligado cumplimiento; potestad de vigilancia e inspección sobre el funcionamiento real de los servicios y el fiel cumplimiento de cuantas obligaciones corresponden a los órganos inferiores; y potestad disciplinaria para la imposición de sanciones a los funcionarios miembros de los órganos inferiores que incumplen sus obligaciones.

La idea de dependencia jerárquica late con fuerza en el seno de la Diputación del reino de Aragón, cuya organización administrativa está supeditada a los titulares efectivos de las atribuciones encomendadas: los 
diputados del reino, que, convertidos en los órganos superiores, proporcionan los criterios de actuación a los órganos inferiores, formados por el resto de oficios y cargos, generalmente profesionales del derecho, que ejecutan sus decisiones y suministran, a su vez, información sobre la realidad concreta a gestionar, contando para todo ello con el auxilio de personal subalterno de muy variada naturaleza.

$\mathrm{Al}$ abordar la nómina de funcionarios y componentes del consistorio aragonés, es preciso tener en cuenta que a fines del siglo XV se consolidó la siguiente división: uno, los oficios del reino, que constituían el grupo central y básico de la Diputación; dos, cargos administrativos elegidos y pagados por la Diputación del reino; y tres, una abultada nómina de cargos y oficiales subalternos que desarrollaban su actividad en el seno de la institución, vinculados de manera formal o eventual. Los oficios del reino, que forman la elite rectora de la institución y los que están al frente de los órganos de apoyo a su gestión cotidiana, son los siguientes: diputados, notarios de diputados, procuradores, abogados, inquisidores de procesos, notarios de inquisidores de procesos, inquisidores de cuentas y notarios de inquisidores de cuentas.

La diferencia básica entre oficios y oficiales o cargos de la Diputación residía en la forma de los nombramientos. Mientras que los oficios del reino se eligen por insaculación, procedimiento regulado foralmente, los cargos vinculados o dependientes de los diputados son elegidos por éstos nominalmente. La estructura de oficios toma su asiento definitivo en 1495 , cuando se determina que los diputados realicen la matrícula de insaculados o lista de todas las personas candidatas a ejercer un oficio del reino y pertenecientes a cada uno de los cuatro brazos con representación parlamentaria: es decir, por cada oficio existían candidatos de cada uno de los cuatro brazos. Posteriormente, la elección mediante insaculación determinaría el nombre elegido.

1. Órganos

1.1. Con función de gobierno

Diputados

1.2. Con función de justicia

Inquisidores de procesos (incoan los procesos de denunciación)

Judicantes (resuelven los procesos de denunciación)

Inquisidores de cuentas (contadores)

Justicia de las montañas 
1.3. Con función de administración

Notarios de los diputados

Extractos

Sustitutos

Notarios especiales

Archivero

Calendador de libros

Del registro de censales

Notario de mandamiento

Notario escribiente

Notarios de inquisidores

Secretario o escribano principal de la Diputación

1.4. Con función hacendística

Administrador del general

Arrendador del general

Inquisidores de cuentas

2. Personal al servicio de los órganos

2.1. Personal técnico administrativo

Abogados (extractos y extraordinarios)

Procuradores (extractos y extraordinarios)

Solicitador de procesos y negocios del reino

2.2. Personal técnico fiscal

Corredor del general

Collidores

Sobrecollidores

Guardas

Sobreguardas

Contadores

Comisarios de viedas de carnes y panes

Sobrejunteros

Lugartenientes de sobrejunteros

2.3. Personal de servicios

Abogado de pobres

Agentes del reino (uno en Roma y otro en Madrid)

Alcaide de la Cárcel de Manifestados

Alcaide de la Diputación

Apotecario

Armero del reino

Capellán 
Carpintero y mazonero del reino

Casero del puente del río Gállego

Cerero

Cerrajero

Confitero

Corredores (pregoneros)

Cronista

Cuchillero

Despensero de los diputados

Empedrador

Iluminador del reino

Impresor

Librero

Lugarteniente de alcaide

Maestro de obras

Médico de la Cárcel de Manifestados

Notario de las Cortes

Notario encargado de hacer las procuras

Obrero de villa

Pagador de la guarda del reino.

Pintor

Platero del reino

Portero de las causas de los pobres

Procurador de pobres

Repartidor de limosnas de los pobres manifestados

Sobrestante de las obras del reino

Solicitador de pobres

Tasadores de mercaderías

\section{Diputados}

En términos generales, los ocho diputados, dos por cada estamento (alta nobleza, caballeros e infanzones, clero y universidades), que componen el equipo de gobierno anual de la Diputación del reino son los responsables de la defensa y regulación del ordenamiento jurídico aragonés. Junto a la función de velar por el mantenimiento de la ley foral, la nómina de diputados se ocupa del bien del reino y de los intereses de toda índole que afectan a Aragón tanto dentro como fuera de sus fronteras. Se consideran la representación del reino, para lo cual desarrollan un importan- 
te programa de proyección institucional. En definitiva, el grupo de diputados constituye la elite rectora de la política y la hacienda del reino, con una autoridad indiscutible, que desarrolla su actividad en virtud de una serie de ámbitos funcionales delimitados por disposiciones forales.

Cinco son los sectores en que los diputados manifiestan y desarrollan todo su potencial: gobierno, administración, justicia, milicia y hacienda. Como cabeza institucional, los diputados determinan y establecen acuerdos ratificados documentalmente en las series de gobierno de la Diputación aragonesa. Toman resoluciones que afectan a las líneas maestras de la política y la diplomacia aragonesa. Resuelven conflictos de naturaleza política o actúan como intercesores entre afectados. Por último, todas las acciones de gobierno se debaten en consistorio y a los diputados concierne su ejecución y cumplimiento dictando las órdenes pertinentes.

Junto a la acción gubernativa, los diputados están obligados a canalizar sus esfuerzos en aras del bien común del reino y su defensa, tanto jurídica como física o militar. Por ello, el control hacendístico a través de la gestión de los ingresos y gastos recae en último término también sobre el consistorio de los diputados. En este sentido, como afirma Ibáñez de Aoiz, los diputados «son administradores, receptores y distribuidores de todos los derechos de las Generalidades del Reino». ${ }^{109}$ Para desempeñar la función de control de los recursos del reino, los diputados se apoyan en un grupo de órganos y funcionarios sobre los que recae el peso de la gestión hacendística, aunque todos están sujetos a la completa jurisdicción de los diputados. ${ }^{110}$ Los desórdenes

109 Lorenzo Ibáñez de Aoiz, Ceremonial..., B.U.Z., ms. 99.

110 Savall y Penén (1866), vol. 2, p. 329: «Item ordenamos que los dichos diputados tengan poder de compelir todas y cada una personas de qualquiere dignidad, preeminencia, estado o condición sean, a pagar a los dichos arrendadores los drechos del general, que juxta la capitulación y arrendación a él fecha son tenidos y obligados pagar. Item queremos que los dichos diputados tengan poder de hazer pagar todas y qualesquiere deudas y restas procedientes de las generalidades del dicho Reyno, inmediatamente por qualesquiere persona o personas \& universidades devidos o devidas \& qualesquiere quantidades por las dichas razones e qualquiere dellas tan solamente restantes a pagarse: oyr de palabra e sinse escriptura qualesquiere questiones, empachos, diferencias, que por la dicha razón se intentarán o farán e aquellas juxta su buen arbitrio e conciencias declarar e determinar \& aquello executar. Item queremos y ordenamos que los dichos diputados tengan poder y jurisdicción civil sobre todos y cada unos arrendadores, fianças y porcioneros del dicho general, cogedores \& sobrecogedores, guardas e otros administrador e administradores del dicho general e fianças de aquellos e sobre los arrendadores, fianças, herederos \& succesores dellos e de qualquiere dellos: \& sobre todas y qualesquiere personas e universidades que 
derivados de la gestión económica y que afectan directamente al impuesto de generalidades (generalmente fraudes de los mercaderes o impagos de los recaudadores directos del impuesto) se resuelven por medio de la vía judicial, que tiene a los diputados como máximo órgano competente con jurisdicción absoluta, aunque su participación no es necesaria. ${ }^{111}$ De hecho, el arrendador tiene capacidad junto con sus oficiales para perseguir a los infractores. ${ }^{12} \mathrm{Y}$ así, muchas veces el asunto ha sido resuelto por el arrendador antes de que pase definitivamente al consistorio. Sin embargo, es preciso recordar que los fraudes cometidos en aquellos territorios que tienen tabla de recaudación son actuados en primera instancia por los jueces ordinarios de la localidad, tal y como dispone el acto de corte aprobado en las Cortes de Zaragoza de 1519: "De juezes locales, conocientes sobre las Generalidades del Reyno». ${ }^{113}$ En este caso, la Diputación actuaría como tribunal de segunda instancia o apelación: "de las sentencias de los quales no se pueda haver recurso alguno [...] y en este caso que tan solamente se pueda haver recurso a los diputados del Reyno».

\section{Notarios de los diputados}

Divididos en extracto y sustituto, estos oficios forman la elite burocrática de la institución: actúan como fedatarios y colaboradores directos en las funciones registrales, documentales y jurídicas derivadas de las

farán o havrán fecho frau o denegación de paga, resistencia o empacho alguno a la colecta del dicho general; e de los dichos drechos o a los oficiales de aquel o aquellas; \& sobre las cosas dependientes, incidientes \& emergentes \& connexas a aquellos e aquellas; e que puedan tomar e hazer tomar e presos detener las personas que no pagarán, farán o havrán fecho frau o contra lo sobredicho delinquido havrán o delinquirán e aquellos civilmente punir; e que los officiales reales e qualesquiere otros, les den, e sean tenidos dar consejo, favor y ayuda, toda hora y quando requeridos serán»

111 Recuérdese a tal efecto que las ordinaciones de 1519 establecían la jurisdicción suprema de los diputados. Savall y Penén (1866), vol. 2, p. 333: "Que los diputados en las causas que conocer pueden, no haya apelación: Item estatuymos y ordenamos que en las causas que los dichos Diputados por fuero, actos de corte o por las presentes ordinaciones conocer pueden, ni en alguna dellas, no se pueda la execución empachar, por vía de apelación, evocación o inhibición, suplicación, firmas de contrafuero, de qualquiere natura sea, o en otra qualquiere manera, haver recurso al señor Rey, lugarteniente general (en caso que haver lo pueda por fuero), governador, regente el officio de la governación, iusticia de Aragón o a sus lugartenientes, ni a otro official alguno, assí ecclesiástico, como seglar, salvo drecho de retractión».

112 José Ángel Sesma (1977), p. 252.

113 Savall y Penén (1866), vol. 2, p. 330. 
actuaciones de los diputados. A ellos corresponde registrar por escrito las deliberaciones del consistorio. Al notario extracto se le adjudica la quinta llave del archivo del reino, con lo que se vincula la fedación con la custodia de la documentación administrativa y la memoria histórica del reino. Junto a esta llave, recibe los sellos con los que validar los documentos emanados de la jurisdicción de los diputados y los actos jurídicos escriturados. ${ }^{114} \mathrm{El}$ notario extracto se convierte también en oficio anual, sometido al procedimiento de insaculación, en 1467. A partir de ese momento se instituye la figura del notario sustituto, que pasa a ser de carácter vitalicio y que realiza en la práctica la mayoría de las tareas burocráticas del consistorio. Los sucesivos notarios sustitutos intentan paliar la necesidad que el consistorio tiene de recurrir a funcionarios especializados que canalicen su creciente actividad a medida que las competencias políticas se hacen más numerosas y complejas.

Según consta en las ordinaciones de la Diputación del año 1519, el notario extracto era el responsable directo de dar las ápocas de los censales cargados sobre el general, testificar los arrendamientos, las luiciones de los censales y testificar los pagos que por orden de los diputados realizase el administrador del general. Junto a estos documentos, se especifica la elaboración de tipologías tan precisas como los registros de "commisiones, cautelas, cartas missivas e otras escripturas que los señores diputados mandarán hazer. E otrosí sea el dicho notario tenido de hazer el quaderno de la insaculación de los officios del Reyno, e testificar el acto de la insaculación, e assentar dichos insaculados en las metrícolas, con el salario dicho tan solamente, y no más». ${ }^{115}$

\section{Procuradores}

Son los oficios encargados de llevar la representación jurídica de los diputados en cuantos negocios y causas impliquen al consistorio aragonés. A su vez, velan por los intereses de la Diputación en cuanto autoridad competente en los asuntos dispuestos por fuero. Como tales, pueden iniciar procedimientos y acudir allí donde los diputados no pueden asistir, y como representantes del reino tienen potestad para hablar en nombre de

114 José Ángel Sesma (1977), pp. 81 y ss.

115 Savall y Penén (1866), vol. 2, p. 337. 
los propios diputados. ${ }^{116}$ Estos procuradores causídicos del reino reciben la procura de los diputados tras la ceremonia de juramento: «Después de haver jurado los procuradores, los señores dipputados les hacen procura largamente, cuya forma se hallará en cada uno de los registros de los actos comunes de la Dipputación y el notario la saca en forma y los procuradores hacen fe della en el registro de los actos comunes de la Real Audiencia». ${ }^{117}$

\section{Abogados}

Dentro de la nómina de oficios de naturaleza jurídica, los abogados ocupan un lugar de especial relevancia. Son los encargados del asesoramiento técnico y jurídico en los pleitos suscitados entre el reino y otras instancias y particulares. Pero, sobre todo, son especialistas en derecho que proporcionan mediante informes técnicos los datos necesarios basados en el conocimiento jurídico para argumentar una actuación o contribuir al proceso de toma de decisiones por parte de los diputados ante cuestiones muchas veces espinosas, como cuando se cometen desafueros o se vulnera en diverso grado el ordenamiento jurídico aragonés.

Según las ordinaciones de 1519, a los abogados del reino se les exige "haverse en dicho officio y de aconsejar y advogar en las causas que les serán encomendadas por los diputados». ${ }^{118}$ Aparecen también como asesores en las consultas elevadas ante la corte del Justicia para poder gastar cantidades extraordinarias.

\section{Inquisidores de procesos}

La función de justicia desarrollada por la Diputación alcanza, por una parte, a los infractores y defraudadores del impuesto de generalidades. Por

116 En las Cortes de Calatayud de 1461 se faculta a los diputados para que los procuradores acusen civil y criminalmente a los infractores contra los guiajes expedidos por la Diputación, previa solicitud y también previo suministro de información a los propios diputados sobre el hecho punible. Vid. Savall y Penén (1866), vol. 1, p. 47; ibídem, pp. 130-132, Cortes de Zaragoza, 1528: «La qual denunciación no solamente por las partes interesadas, más aún por el procurador del Reyno pueda ser dada. El qual procurador sea astricto dar la dicha denunciación, y proseguir aquélla hasta sentencia definitiva y execución de aquélla inclusive, a expensas del Reyno, como de parte abaxo se contiene».

117 Lorenzo Ibáñez de Aoiz, Ceremonial..., B.U.Z., ms. 199, f. 71v-72r.

118 Savall y Penén (1866), vol. 2, p. 338. 
otra, el progresivo control de las actividades de los funcionarios dependientes de la corte del Justicia y del propio Justicia se canaliza en torno a una serie de actuaciones que velan por el correcto funcionamiento de dicho tribunal. Para ello, los diputados del reino cuentan con los resortes legales que permiten fiscalizar la actuación de los lugartenientes del Justicia y sus órganos subalternos. Pero también los funcionarios dependientes de las instituciones reales quedan sujetos a procesamiento por una actuación indebida. Ibáñez de Aoiz indica contra qué oficios, oficiales y órganos se puede incoar proceso denunciatorio por parte de los inquisidores de procesos:

Se intima y notifica a qualquiere persona, colegio, universidad del presente Reyno de qualquiere grado o condición sean, que pretendan ser agraviados o tengan queja del Señor Justicia de Aragón, o de sus lugartenientes, notarios, o bergueros de aquél, sobrejunteros, lugarteniente de aquellos, poteros del número de doce, o de qualesquiere otros porteros bergueros o de qualesquiere del officio de los alguaciles de su Magestad o de lugarteniente general o de los alguaciles del señor regente el officio de la general gobernación, [...] que comparezcan delante de los dichos señores inquisidores. ${ }^{119}$

En los procesos de denunciación, los inquisidores de procesos actúan como incoadores de todo el proceso, correspondiendo a los judicantes la resolución del proceso dictando sentencia, salvo en los casos prevenidos por fuero. Este tribunal interno de inquisidores de procesos, dependiente de los diputados aragoneses, está acompañado de un pequeño grupo de asistentes jurídicos en torno a los notarios de inquisidores, que actúan como fedatarios y secretarios de todas las deliberaciones conducentes a formalizar y concluir los procesos de denunciación.

\section{Judicantes}

También llamados jueces de la «diecisetena» por ser diecisiete los jueces, son los encargados de dictar sentencia en los procesos de denunciación contra la corte del Justicia. Una vez jurados los cargos ante los diputados, los inquisidores les entregan con acto testificado por el notario los procesos de denunciación por resolver. Los judicantes tienen un tiempo establecido para oír a las partes y dictaminar sentencia definitiva: hasta el día 20 del mes de julio. Como tribunal dentro del esquema organizativo de la

119 Lorenzo Ibáñez de Aoiz, Ceremonial..., B.U.Z., ms. 199, f. 41v y ss. 
Diputación del reino, los judicantes también apoyan sus decisiones en un reducido número de asistentes compuesto por dos letrados, un notario de judicantes y un portero. Una vez pronunciada sentencia, los judicantes, junto al notario y al portero, acuden a la casa del imputado para comunicarle el fallo definitivo.

Inquisidores de cuentas (contadores)

Además de supervisar la compleja gestión económica de la Diputación y del impuesto de generalidades, los inquisidores de cuentas tienen competencia sobre los siguientes asuntos que constituyen la misión fiscal y de control del ejercicio de los propios diputados:

a) Si los diputados han malversado fondos de las generalidades o han admitido sobornos para realizar insaculaciones fraudulentas.

b) Si los diputados han residido en Zaragoza y han asistido a las sesiones del consistorio, para lo cual el registro de asistencias y pólizas resulta ser un instrumento documental de gran valor.

c) Si los diputados han supervisado (residenciado) la función del archivero del reino.

d) Si las pólizas despachadas por los diputados contra el administrador han sido firmadas por los cinco diputados, tal y como previene el fuero, y si han mandado pagar más cantidades de las permitidas por fuero.

e) Los inquisidores de cuentas pueden ser parte en la luición de censales cargados sobre el general, aunque el fuero de 1564 otorga esta capacidad únicamente a los diputados. ${ }^{120}$

f) Hacen encautes, es decir, advertencias acerca de lo que se puede o no gastar en los próximos ejercicios económicos.

En suma, los inquisidores tienen la responsabilidad de velar por la correcta utilización de la hacienda del reino, examinando si se han empleado las rentas y censos en la paga ordinaria de los salarios de los oficios y oficiales del reino, los gastos de la administración de justicia, etc. En el supuesto de que los diputados, o el administrador y arrendador, se hayan

120 Savall y Penén (1866), vol. 2, p. 401. 
excedido en el gasto permitido, deben encautar (advertir) que se recobre lo sobregastado, pudiendo hacer ejecutar las penas estipuladas por fuero.

Los contadores, según se desprende de las ordinaciones de 1519, nombraban a un experto contable conocido como examinador de contos: "persona apta $\&$ sufficiente experta en natura de cuentas, para ver, reconocer y examinar \& amputar todas las cuentas de la Diputación, en poder de los dichos contadores daderas». Una vez recibidas las cuentas efectuadas por este examinador, los inquisidores de cuentas, en número de cuatro, examinan las partidas económicas para determinar si existen irregularidades en los pagos, en los ingresos y en los gastos. El voto de calidad, en caso de que dos contadores determinen lo contrario a los otros dos, se asigna al examinador de cuentas. ${ }^{121}$

Los inquisidores de cuentas se reúnen en una sala en la que colocan «una messa grande que de ordinario la forman de un tablero grande de los que sirven para los consejos y en una mesa grande de nogal de tixera que ay en las casas de la Diputación; ponen en esta mesa unos tapetes verdes y agora los tienen de damasco y la rodean de bancos escaños». ${ }^{122} \mathrm{El}$ primero de junio por la mañana, los contadores se juntan y nombran al perito contable anteriormente aludido, que actúa como quinto contador, cuyo juicio es determinante en caso de empate técnico en una decisión. El horario en que habitualmente se pasan las cuentas de la Diputación se establece de 9 a 11 por la mañana y de 3 a 5 por la tarde. Los porteros de este órgano de control hacendístico avisan a los diputados entrantes y salientes, a sus notarios y al administrador para que asistan a revisar las cuentas del ejercicio anterior. Es entonces cuando, una vez todos sentados de acuerdo al complejo ceremonial interno de la Diputación, los administradores de las generalidades del año anterior traen los libros de cuentas. El quinto contador toma el libro de cuentas del administrador para comprobar si se han asentado correctamente las entradas y salidas, contrastando su libro con las ápocas de los pagos efectuados por mandato de los diputados. Conforme se lee una partida y se comprueba con la ápoca, éstas son cosidas por un portero. ${ }^{123}$

121 Savall y Penén (1866), vol. 2, p. 335.

122 Lorenzo Ibáñez de Aoiz, Ceremonial..., B.U.Z., ms. 199, f. 59v.

123 Ibídem, f. 61v. 
Las sentencias de los inquisidores de cuentas tienen ejecución por vía privilegiada y no se pueden impedir ni por inhibición, firma casual, privilegiada ni por otro medio jurídico, tal y como lo dispone el fuero promulgado en las Cortes de Zaragoza de 1646. ${ }^{124}$

\section{Administrador del general}

Es el responsable de la gestión contable del impuesto de generalidades, aunque toda su actividad está directamente supervisada por los diputados y por órganos fiscalizadores como los inquisidores de cuentas. Generalmente, el cargo de administrador y arrendador coinciden en una misma persona. ${ }^{125}$ En términos generales, se ocupa, mediante las correspondientes órdenes de pago o cautelas, de recibir los ingresos y gestionar los gastos de la institución que, por orden de los diputados, se generen en cada ejercicio. Todas las operaciones derivadas de estas actuaciones quedan reflejadas en el libro de cuentas del general, distribuido en torno a tres conceptos: ingresos, gastos y resumen final aprobado por los diputados. El administrador se encarga de hacer efectivos los pagos que los diputados deciden, mediante orden de pago o cautela. Esta orden de pago debe estar firmada por cinco diputados para ser efectiva y es una tipología frecuentísima en los registros de actos comunes.

\section{Arrendador}

Aunque no forma parte de la nómina de oficios extractos mediante insaculación, es el eje sobre el que pivota toda la actividad hacendística ordinaria de la Diputación. Es el nexo entre la hacienda del reino y los diputados, como encargado de realizar la gestión de las entradas y salidas de mercancías y su conversión a libras para determinar un balance económico al final de cada ejercicio. En teoría es el responsable directo del cobro del impuesto de generalidades a lo largo de los puntos de la geografía aragonesa establecidos para la colecta. Los arrendadores son hombres de negocios que entienden el arriendo de las generalidades como una inversión más. Por ello son también los responsables de la contratación de

124 Savall y Penén (1866), vol. 2, p. 490.

125 Las competencias y actividades encomendadas al administador del general, en José Ángel Sesma (1977), p. 105. 
cuantos oficiales necesite para llevar a cabo la costosa labor de recolección del dinero entregado en cada punto aduanero. A tal efecto, cuenta con el servicio de collidores, sobrecollidores, guardas y sobreguardas.

\subsection{Funciones}

Los documentos que componen un fondo de archivo han sido generados, reunidos o recibidos de forma espontánea como resultado de la actividad que la entidad que los produce realiza durante el ejercicio de sus funciones, con objeto de cumplir una serie de objetivos. Para ello suele disponer de una estructura administrativa y de unas normas de actuación que regulan todo el proceso de génesis documental. Los órganos y las funciones conforman estos elementos imprescindibles en todo el proceso de génesis documental. Entendemos por función el tipo de acción que constituye una atribución encomendada a una institución para que realice y cumpla los fines para los que fue creada. Estas funciones originan un conjunto de actividades destinadas a realizar unos servicios necesarios para conseguir los fines. Finalmente, estas actividades se plasman en un conjunto de trámites necesarios para poner en marcha esa actividad, que se recogen en las series documentales.

La compleja actividad desplegada por la Diputación aragonesa a lo largo de su historia se vertebra, como hemos dicho, en el trabajo de los órganos de decisión, administrativos y judiciales que componen la estructura orgánica de la institución. Sin embargo, es la evolución de las funciones, las competencias y las atribuciones de la Diputación el patrón que determina su razón de ser. La actividad de unos órganos (oficios y cargos), en virtud de unas funciones, atribuciones y competencias, se reflejan en los procesos de creación, tramitación, organización, custodia y consulta de los documentos generados en el transcurso de dichas funciones.

Los principios de organización que rigen la visión dinámica de las instituciones y que afectan a la esfera de su actuación hacen referencia a los conceptos de competencia y coordinación. Se entiende la competencia como el "conjunto de posibilidades de actuación de un órgano». Y habría que diferenciar entre funciones (desarrolladas por la totalidad de la institución) y competencias (reservadas para cada uno de los órganos que componen 
dicha institución). ${ }^{126} \mathrm{La}$ coordinación de las competencias implica la existencia de un órgano con un poder suprainstitucional que delimita los conflictos de competencias existentes entre órganos. Lorenzo Ibáñez de Aoiz, buen conocedor de la estructura interna de la Diputación del reino y testigo de su organización administrativa, sintetiza el papel de la institución en un párrafo que aclara sus funciones y ámbitos generales de actuación:

Bastante poder como hoy tienen, el qual, generalmente, consiste en tres cosas: la primera que son autores y acusadores en los casos por los fueros y actos de Corte del presente Reyno expresados; la segunda que son administradores, receptores y distribuydores de todos los drechos de las Generalidades del Reyno, de la manera que los fueros y actos de Corte de él lo disponen. La tercera, que tienen jurisdicción en las cosas tocantes a las generalidades y en los demás casos en los fueros y actos de corte expresados. ${ }^{127}$

José Ángel Sesma, en la definición preliminar de la Diputación del reino de Aragón, apela a cinco puntos esenciales que resumen la naturaleza de la institución: representatividad estamental permanente, intervención en asuntos internos y externos que afectan al reino, carácter fiscal, político y administrativo, delegación o emanación de las Cortes y, finalmente, vigilancia y cumplimiento de fueros y libertades del reino. ${ }^{128}$

Estos cinco apartados, de carácter muy general, determinan, tras su análisis pormenorizado, el conjunto de las funciones específicas desarrolladas por la Diputación por mano de los propios diputados o de los oficios y cargos adscritos o supervisados por ellos.

La reflexión sobre los contenidos y la sistematización del ejercicio del poder por parte de las instituciones del Antiguo Régimen se concreta en una clasificación de las funciones desarrolladas por éstas. El análisis de Hespanha sobre las instituciones del Portugal del siglo XVII resume perfectamente las estructuras del ejercicio del poder y su plasmación general en un conjunto de funciones globales que articularán en un segundo término la maquinaria administrativa y el recurso a la escritura y a la organización documental como factores de eficacia burocrática:

126 Mariano Baena del Alcázar (1990), p. 73.

127 Lorenzo Ibáñez de Aoiz, Ceremonial..., B.N.E., ms. 2922, f. 4r.

128 José Ángel Sesma (1977), pp. 30-31. 
El registro escrito constituye un medio revolucionario - respecto a las técnicas de la oralidad- de almacenar la información. Archivos, catastros, mapas y plantas, descripciones corográficas, códigos, he aquí una enorme gama de materiales de apoyo a la decisión política que, ahora, están a disposición del monarca. En Portugal, como en los demás reinos de España, estas técnicas eran dominadas desde hacía mucho tiempo, pero en el siglo XVI se da un salto hacia adelante con la constitución de bases documentales con finalidades de gestión administrativa. ${ }^{129}$

Hespanha distingue «los grandes sectores funcionales de las actividades del poder» en los siglos XVI y XVII: justicia, estado, guerra, gracia, conciencia, hacienda y gobierno. ${ }^{130}$ División que coincide en términos generales con la propuesta por Pérez Bustamante, si bien bajo el término de servicios del Estado durante la Edad Moderna: justicia, administración financiera, administración militar, divididos de las funciones de gobierno y administración. ${ }^{131} \mathrm{Al}$ proyectar este análisis sobre las instituciones privativas del reino de Aragón, surge con fuerza la función de hacienda como una de las funciones básicas que determinan la naturaleza económica y fiscal de la Diputación aragonesa. Sin embargo, en el proceso de acumulación de competencias que culmina a mediados del siglo XV, la Diputación se convierte no sólo en administradora absoluta del impuesto de generalidades, sino que se transforma también en garante del ordenamiento jurídico, juez competente en delitos cometidos contra dicho impuesto, garantizadora de la paz interna, representante del reino, gestora de la hacienda de éste y rectora, en última instancia, de la política aragonesa.

Ignacio de Asso, conocedor del archivo del reino, donde se valió de fuentes documentales para completar su Historia de la Economía Política, realizó un acertado ensayo definitorio de la Diputación, caracterizando globalmente la institución:

El Consistorio, cuyo origen ignoramos, se componía de ocho diputados, que se sorteaban anualmente dos de cada brazo; y en el de las Universidades había siempre un ciudadano de Zaragoza. Eran unos procuradores autorizados de todo el reino para cuidar de la observancia de las leyes, a cuyo cargo estaban también los asuntos de policía, y en especial todo lo respectivo a la conservación y reparo de los puentes, caminos y otros edificios públicos, para lo

129 António M. Hespanha (1989), p. 228.

130 Ibídem, p. 220.

131 Rogelio Pérez Bustamante (1995), pp. 163-175. 
cual despachaban comisiones a los pueblos, y tomaban cuenta de los caudales invertidos en las obras públicas, hechas en su orden. Tenían asimismo encomendada la superintendencia general de las rentas de las Generalidades, de los tributos, que se establecían en Cortes para los servicios, que el Reino hacía a los Señores Reies, y de todo lo concerniente al comercio, importación y exportación de mercaderías, vedas y permisos de extraher los frutos del reino. ${ }^{132}$

Funciones, por tanto, relativas al gobierno político, pero también al económico, representado por la hacienda del reino, y a las esferas de la actividad de justicia en una parcela tan determinada como los delitos contra la administración del impuesto de generalidades, caracterizando así la tradicional asunción de diversas competencias (gubernativas, hacendísticas y judiciales) por una misma institución. ${ }^{133}$ Sin embargo, tampoco se debe olvidar la función denominada de «justicia distributiva», relacionada con la administración de la "gracia» institucional, referida a las concesiones y ayudas pecuniarias que los diputados del reino dieron a individuos concretos (beneficencia) o a núcleos de población con necesidades económicas puestas en conocimiento del consistorio aragonés por medio de los procesos de suplicación. Naturalmente, al igual que sucede con la administración central moderna, caracterizada por la definición de los procesos de escritura y documentación, la Diputación del reino de Aragón canalizará dichas funciones a través del registro de la escritura de los actos jurídicos en cuantas tipologías documentales definan la función institucional.

\subsubsection{Funciones de gobierno}

Los diputados del reino constituyen la cúspide de la estructura organizativa institucional. Ellos representan la más alta instancia en la Diputación. Su participación en todos los actos generados en el seno de ésta permite hablar del consistorio de los diputados como de su órgano de gobierno esencial. No obstante, su jurisdicción y competencias se amplían foralmente al mantener la representación global del reino, el derecho y la obli-

132 Ignacio Jordán de Asso (1798), en la edición de 1983, p. 19.

133 Con respecto a los consejos de la monarquía hispánica, Mariano Baena del Alcázar (1990), p. 86: «Para entender el sistema administrativo de la época, cuyo núcleo son los Consejos, hay que tener en cuenta que no existe una separación entre ejecución y justicia, entre lo que ahora llamaríamos asuntos administrativos y asuntos judiciales». 
gación de respetar el ordenamiento jurídico e intervenir en todos aquellos aspectos que afectan política o económicamente al reino. Pero también se reserva una pequeña parcela de atribuciones judiciales, al mantener la jurisdicción civil sobre los fraudes y actos delictivos cometidos contra la administración de las generalidades del reino. En suma, los diputados reúnen atribuciones de gobierno, pero también de justicia para los casos específicos regulados por fuero cuando se vulnere el sistema organizativo del impuesto de aduanas aragonés o esté comprometido el abastecimiento al propio reino de productos de primera necesidad.

La función gubernativa está orientada hacia dos direcciones: hacia el propio reino - interna - y hacia el resto de los territorios de la monarquía hispánica — externa—. Es evidente que la Diputación juega un papel decisivo en las desiguales relaciones entre la Monarquía y el reino de Aragón. La representación de éste en cuantas instancias fuese necesaria aviva el carácter representativo y estamental de la institución. Por otra parte, la gestión de los asuntos que afectan exclusivamente al reino obliga a los diputados a tomar parte activa en cuantas súplicas, desórdenes, conmemoraciones, etc., se produzcan por toda la geografía aragonesa. De todas las actividades y funciones emanadas de esa doble concepción de gobierno y representación (interna y externa) se derivan importantes acuerdos, órdenes, instrucciones, embajadas y cuantos actos jurídicos se documentasen a lo largo de los siglos.

Como consecuencia de la actividad rectora de la política del reino, de la propia organización interna de la institución y de la hacienda del reino, los diputados precisan la ayuda de los oficios administrativos. En términos diplomáticos, se podría hablar de una participación activa de los diputados en la actio de cuantos actos jurídicos se documentasen en el seno de la institución. Por su parte, la conscriptio o escrituración de dichos actos generados en virtud de las funciones y competencias correspondería a cuantos notarios, escribanos y personal administrativo de apoyo dependiese de los diputados.

El resultado directo de las actuaciones gubernativas desplegadas por los diputados se manifiesta en tipologías documentales concretas que determinan las series de gobierno generadas o recibidas por la institución en el desarrollo de sus competencias. 


\subsubsection{Funciones de administración}

Las competencias gubernativas, judiciales y hacendísticas atribuidas a la Diputación del reino obligan al establecimiento de pautas de funcionamiento interno que garanticen el éxito y la eficacia de su desarrollo. Toda institución delimita una parcela de naturaleza interna compuesta por aquellas actividades de control y gestión estrictamente administrativas, necesaria e imprescindible para argumentar y apoyar las actuaciones, decisiones y actos que determinan las funciones institucionales. A este respecto, la Diputación del reino de Aragón se dotó de un sistema administrativo interno que permitía consolidar la documentación generada y tramitada en el seno de las escribanías de la institución como un recurso de primer orden para garantizar el funcionamiento del engranaje institucional. ${ }^{134}$

A tal efecto, la elección de los notarios (extracto, sustituto y extraordinarios), así como el nombramiento del secretario y escribano principal de la Diputación, constituye la muestra del papel que los oficios y cargos de naturaleza administrativa y documental desempeñaron en el organigrama de la institución. No obstante, el normal funcionamiento de ésta también afecta a aquellas actividades necesarias y presentes en toda institución del Antiguo Régimen. El control de la asistencia de los propios diputados a las sesiones ordinarias, el pago de los salarios de todos los cargos dependientes de la Diputación, la gestión administrativa del sistema documental de la institución representado por las hojas de remisión de fondos al archivo y la extracción de registros de éste para su consulta, etc., constituyen actos de administración interna que garantizan la flexibilidad de la institución $y$, en último término, la eficacia de las funciones encomendadas. La función de administración interna de la Diputación del reino de Aragón afecta, por tanto, a cuestiones de administración económica interna y de control de sus oficios, así como al subsistema de génesis, organización, descripción y consulta documental.

134 Antonio Castillo (1998), pp. 371-372: «Conservar las escrituras se convierte en necesidad para un Estado cada vez más burocratizado. Guardados, los papeles responden a las exigencias diarias de la práctica política y administrativa; pero, además, marcan operaciones de preservación del poder y estrategias de la memoria. La utilidad cotidiana e inmediata de la conservación y ordenación de los papeles del Estado se comprueba por los problemas derivados del carácter itinerante. No disponer de los testimonios escritos en el momento oportuno generaba no pocas dilaciones y vicios en el funcionamiento de la maquinaria burocrática». 


\subsubsection{Funciones de hacienda}

Se tiende a identificar el nacimiento de la Diputación del reino de Aragón con el establecimiento del impuesto de generalidades, que derivaría con el tiempo en la completa gestión de la hacienda del reino por contraposición a la propia del monarca y a la gestionada por los municipios. ${ }^{135}$ Juan Pérez de Nueros, abogado fiscal de Felipe II, escribía hacia 1577, con relación al impuesto de aduanas aragonés, que

Estas generalidades del Reyno, son cierto derecho que por acto de corte está ympuesto sobre las mercaderías que salen del Reyno y entran en él, el qual se rige y administra por ocho oficiales, que se dicen los diputados del Reyno, que cada un año salen por suertes, dos de cada brazo o estado; y los dichos derechos sirven para utilidad del Reyno, para emplearlos y gastar las pensiones de los censales que están cargados sobre el Reyno, salarios de oficios y otras cosas en que se pueden y deben gastar conforme a lo que por fueros y actos de corte está ordenado; sin que el Rey ni sus oficiales se puedan intrometer en la administración, ni otra cosa alguna tocante a las generalidades; las quales comúnmente arriendan por tres años y en cada un año se pagan más de ochenta mil escudos, porque como an subido mucho las mercaderías, creçido en grande manera el valor de los derechos que se exigen según la estimación de las mercaderías; llebando de algunas el veinteno y de algunas el trinteno y de otras, más o menos, según que por acto de corte está ordenado. [...] y así, esta manera de generalidades es de grande importancia, y la mayor fuerça que ay en el Reyno para defender y conservar los fueros y libertades de aquél y para gastar todo lo que conviene para el beneficio público y universal del Reyno. ${ }^{136}$

135 Ignacio Jordán de Asso (1798), en la edición de 1983, pp. 247-248: «El derecho del General se exigía con tal rigor y sin excepción de personas, que en los principios lo pagaba el mismo Rei y familia real, según lo establecido en las Cortes de Teruel de 1427, hasta que en 1519 se declaró que las ropas y joyas de las personas reales fueran francas de derechos, quando vinieren personalmente a este Reino; pero que los pagasen en caso de transitar el dinero y alhajas a otra Provincia. En efecto, habiendo escrito el Rei a los Diputados en 1521 que restituyesen los 122 ducados de derechos por el dinero que el Tesorero de Indias había pasado por Aragón a Barcelona, declararon que no había lugar. Es verdad que en algunas ocasiones se tubo la atención de franquear los derechos de las cosas destinadas para uso de Su Majestad. [...] El derecho de nuestras Aduanas fue en su origen un 5 por 100 de todo lo que entraba y salía del Reino: a excepción de algunas mercaderías que pagaban el diez y continuó sobre este pie por muchos años, sino es una u otra ocasión en que las expensas extraordinarias precisaron a subir este derecho, que llamaban aumento del General. Así sucedió en 1400 en que fue preciso para satisfacer las muchas deudas del Reino, cargar 3 dineros más por espacio de 6 años sobre los 12 dineros por libra, que entonces se pagaban, pero en el de 1404 se subrogó este nuevo derecho en la contribución ordinaria, que llamaban Fogage».

136 Sumaria noticia de algunas cosas del Reino de Aragón. Autor el doctor Juan Pérez de Nueros, abogado fiscal del señor rey Felipe II, [1577], B.N.E., ms. 1894, f. 14v. 
De hecho, uno de los pilares básicos de la institución, junto con la defensa del ordenamiento jurídico foral aragonés, lo constituye la administración del sistema hacendístico del reino, basado en los ingresos y gastos ordinarios y extraordinarios. La gestión de los ingresos y los gastos que afectan directamente al territorio aragonés moviliza abundantes recursos, participantes y disposiciones legales, y tiene consecuencias de gran importancia en el plano documental. Estudiado con gran detalle el sistema hacendístico aragonés por José Ángel Sesma, tan sólo indicaremos a continuación algunas consideraciones necesarias para articular nuestro enfoque documental. ${ }^{137}$

El sistema fiscal encomendado a la incipiente Diputación de finales del siglo XIV no se basa en el tradicional recuento por fuegos de los anteriores procedimientos recaudatorios. El nuevo método perfilado en 1363, denominado generalidades, atiende a dos conceptos esenciales: la recaudación de una tasa aplicada a cuantos productos entren o salgan de las fronteras del reino, para lo cual se necesita dotar a una institución (Diputación del reino) de los resortes jurídicos y administrativos necesarios para su recaudación, gestión y óptimo aprovechamiento. En suma, como indica Sesma, "desde mediados del siglo XIV la idea de General está en íntima relación con otros dos conceptos: Diputación y Generalidades, constituyendo una unidad, en torno a la cual gira el mundo político-económico aragonés, que en el siglo XV se erige con la representatividad de Aragón y es considerado como "anima del regno" ». ${ }^{138}$ Para su gestión fue necesario definir el territorio sobre el que se aplicaría el impuesto de generalidades y la red de recaudadores mediante el establecimiento, a efectos fiscales y de recogida, de los montos pecuniarios dejados por el tránsito de mercancías de las sobrecollidas o demarcaciones que agrupaban las collidas o puntos de cobro del impuesto. El personal encargado de la recaudación estaba formado por los sobrecollidores, collidores y guardas, dependientes directamente del arrendador. Es precisamente el arrendador de las generalidades una de las piezas básicas en el sistema fiscal del reino. La gestión del impuesto podía realizarse bien directamente por parte de los diputados o por persona interpuesta representada por el arrendador: «la persona que

137 José Ángel Sesma (1977), pp. 104 y ss., y (1976).

138 José Ángel Sesma (1977), p. 102. 
toma el arriendo es un hombre de negocios, que acepta la empresa como una inversión y, por tanto, su meta es la de obtener los mayores beneficios. Por su parte, el reino se asegura por este sistema una cantidad fija, sin depender directamente del resultado del ejercicio, que le sirve para cubrir los gastos presupuestados». ${ }^{139} \mathrm{La}$ administración de este impuesto obliga a los administradores del general y a los diputados del reino a desarrollar una intensa actividad administrativa y contable, manifestada en varias series documentales.

En cuanto a los ingresos extraordinarios, éstos consisten en la emisión de censales o títulos de deuda pública sobre el impuesto de las generalidades y en el irregular impuesto de la sisa. La cuantía de estos ingresos estaba determinada por las Cortes. El censal o «empréstito sobre el reino y sus bienes, emitido a un determinado tipo de interés» fue uno de los medios más eficaces que la Diputación del reino tuvo para disponer rápidamente de liquidez económica y sufragar así el subsidio ofrecido al monarca, según los acuerdos determinados en las reuniones de Cortes. Todo individuo podía invertir en censales que, tras su compra, se convertían en nominales. El inversor recibía un título testificado por alguno de los notarios de la Diputación. En él se indicaba el nombre del propietario, la cantidad y el interés o pensión que reportaba. Estos censales o deuda pública se luían o absorbían por el propio reino tan pronto como dispusiese de las cantidades para aligerar así la carga fiscal de los títulos cargados sobre su hacienda. En todo el trámite administrativo desarrollado en torno a la gestión de la deuda pública se atiende a varios conceptos: la anotación de los propietarios de los censales, el cambio de la titularidad de dichos títulos o censales y el pago de las pensiones o intereses generados por los censales.

No obstante, dentro del apartado de la gestión de la hacienda del reino es preciso tomar conciencia sobre la gestión económica derivada de las actividades militares procedentes del gobierno de los diputados. El apoyo militar a las campañas de la Monarquía propició que en ocasiones el reino levantase a su costa contingentes de desigual número e importancia para contribuir al servicio de armas. De esta función de milicia derivada del gobierno de la Diputación quedan pocos restos documentales, siendo éstos de naturaleza económica y representados por las tipologías encarga-

139 José Ángel Sesma (1977), p. 115. 
das de anotar el pago a cada uno de los soldados integrantes de dichas compañías. Por ello se entiende que el gasto ocasionado por el equipamiento y la soldada revierte negativamente en la hacienda del reino, gestionada directamente por los diputados.

\subsubsection{Funciones de justicia}

La acumulación de competencias de naturaleza gubernativa, administrativa y judicial es una característica común a las instituciones del Antiguo Régimen. La progresiva asunción de poder por los diputados del reino acaba en el control administrativo, pero también judicial, de los asuntos relativos al impuesto de las generalidades. ${ }^{140} \mathrm{El}$ proceso culminado a mediados del siglo XV es subrayado por González Antón, quien destaca el gran poder acumulado por la Diputación aragonesa en materia no sólo fiscal y administrativa, sino también judicial: «Pero el asunto era más grave, porque se perfila ahora lo que se apuntaba ya en Cortes de Teruel: los diputados pueden juzgar y castigar con poder absoluto los pleitos derivados del cobro de generalidades, sin que quepa recurso no ya al Rey o al Gobernador, sino al propio Justicia de Aragón, y sin que valieran tampoco la firma de contrafuero o cualquier otra garantía foral». ${ }^{141}$ En términos generales, la total jurisdicción de los diputados se extiende a los delitos cometidos en perjuicio del impuesto de generalidades y su gestión. Las causas seguidas por fraudes, delitos por extracción de panes y carnes del reino, etc., no tienen apelación posible, siendo los diputados la más alta instancia judicial. Ignacio de Asso lo describe en los siguientes términos: «Por esta razón eran los Diputados Jueces privativos en los pleitos que se suscitaban sobre adeudo de derechos y fraudes; publicaban bandos y prohibiciones de sacar moneda, trigo, aceite y otros comestibles, y exercían parte de la jurisdicción criminal sobre los oficiales y empleados en las Aduanas, que delinquían». ${ }^{142}$ En este apartado, la vigilancia de los diputados para que estuviese garantizado el abastecimiento de los productos bási-

140 José Ángel Sesma (1977), p. 103: «A lo largo de la segunda mitad del siglo XV, que coincide con el momento de mayor apogeo de la Diputación, son numerosas las manifestaciones de los diputados tendentes a hacer patente su exclusivismo para tratar los asuntos del General, excluyendo cualquier otra jurisdicción y erigiéndose en jueces supremos [...]».

141 Luis González Antón (1999), p. 111.

142 Ignacio Jordán de Asso (1798), en la edición de 1983, p. 246. 
cos (carne y pan) a todo el reino constituyó otra función judicial, e incluso policial, para perseguir la salida fraudulenta de estos productos de las fronteras del reino en épocas de escasez. Los conflictos entablados por el asunto de las generalidades, así como los derivados del control de los procedimientos de insaculación de los oficios o la vigilancia de la actividad del Justiciazgo, determinan una suerte de justicia administrativa orientada a resolver las desviaciones del ordenamiento jurídico.

El asunto de la jurisdicción de los diputados queda jurídicamente delimitado en la compilación foral aragonesa, e indicado en los fueros, observancias y actos de corte oportunos. En 1519 se determina que en las causas que pueden conocer los diputados no haya posible apelación: «Item estatuymos y ordenamos que en las causas que los dichos Diputados por fuero, actos de corte o por las presentes ordinaciones conocer pueden, ni en alguna dellas, no se pueda la execución empachar, por vía de apelación, evocación o inhibición, suplicación, firmas de contrafuero, de qualquiere natura sea, o en otra qualquiere manera, haver recurso al señor Rey, lugarteniente general (en caso que haver lo pueda por fuero), governador, regente el officio de la governación, iusticia de Aragón o a sus lugartenientes, ni a otro official alguno, assí ecclesiástico, como seglar, salvo drecho de retractión». ${ }^{143}$

No obstante, la acción judicial de la Diputación se traslada, como se ha indicado arriba, también al control que la institución ejerció sobre la corte del Justicia de Aragón. A través de los inquisidores de procesos y los diecisiete judicantes, todos oficios del reino, se asiste a la limitación judicial de la actividad desarrollada por los lugartenientes del Justicia, vigilando sus extralimitaciones y excesos en el ejercicio de sus cargos.

Existe otro ámbito de la función judicial que afecta a la organización interna de la Diputación y sus oficios. Las continuas protestas por supuestas irregularidades en el proceso de insaculación, así como los trámites previos necesarios, derivan documentalmente en los procesos de insaculaciones y de habilitación de infanzonías respectivamente. Con ellos se trata de dar transparencia a todo el proceso de elección de los oficios del reino, garantizando las calidades forales requeridas (habilitaciones de infanzonía)

143 Savall y Penén (1866), vol. 2. 
y la subsanación de los abusos e irregularidades cometidas (procesos de insaculaciones).

Finalmente, la denominada por A. M. Hespanha «justicia distributiva» es otra función desplegada por la Diputación, representada por las ayudas y concesiones económicas que aprobasen los diputados para mejorar la red viaria, ayudas para sufragar impresiones, etc., estableciendo un vínculo entre los regnícolas y la propia Diputación como máxima instancia en el reino en lo que a gestión de la res publica aragonesa se refiere.

De las atribuciones judiciales desplegadas por la Diputación se derivan lógicamente acciones jurídicas plasmadas sobre documentos. Estas acciones dan lugar a un conjunto de tipologías documentales que forman las series de justicia del consistorio aragonés, sustentadas en los procesos, que tras el fuero de 1564 se permitió pudiesen hacer prueba y tuvieran la misma validez ante cualquier otro tribunal de justicia foral o real. ${ }^{144}$

144 Savall y Penén (1866), vol. 1, p. 402: «De las letras emanadas del Consistorio de los Diputados. Teniendo fin de revelar de costas a las partes que trataren pleytos delante los Diputados del Reyno, y que no sean obligados a sacar copias de los processos que ante ellos actitaren, para hazer fe dellos en otros consistorios y Tribunales. Su Magestad de voluntad de la Corte estatuece y ordena que las letras emanadas de los dichos procesos hagan tanta fe como si se exhibiesen los processos o copias dellos hasta que conste por el processo alguna cosa en contrario de lo contenido en ellas, estando el processo en ser, y no estando el processo en ser; y de las cosas tratadas verbalmente ante los Diputados, las tales letras no hagan fe». 



\section{PRODUCCIÓN Y GÉNESIS DOCUMENTAL}

\subsection{Procedimiento administrativo general}

La función administrativa inherente a toda institución con cierto grado de complejidad se desarrolla en torno a un importante número de actividades que sustentan las acciones cotidianas y garantizan el éxito en la consecución de los objetivos institucionales. La diversidad de dichas funciones determina la especialización burocrática y la dotación de un aparato administrativo eficaz y sustentado en los procesos de génesis, tramitación y custodia documental como características esenciales. A la dotación inicial necesaria e inherente a la creación de la Diputación del reino de Aragón se incorporó una plantilla creciente de funcionarios imprescindibles para sostener la gestión documental. Funcionarios que se encargaron de poner por escrito los actos jurídicos emanados del consistorio, ilustrando así la fase diplomática correspondiente a la conscriptio, derivada de la actio emanada de los diputados y su capacidad de gobierno y regimiento de la Diputación aragonesa.

Todo el proceso de génesis y custodia documental se muestra en una cadena sucesiva y complementaria de elementos y actividades interrelacionadas cuyo correcto desarrollo y gestión determina la eficacia de la práctica de la escritura, su utilización para el consistorio aragonés y finalmente su conservación como memoria permanente del reino. Por tanto, en todo el sistema cabe hablar de unos funcionarios actuantes, un lugar de producción documental, representado por las escribanías de la Diputación, y un conjunto de actividades de naturaleza administrativa y documental que concluyen con las tipologías tramitadas y puestas a disposición de los procedimientos de consulta documental. 


\subsubsection{Funcionarios actuantes}

Como se ha indicado en líneas precedentes, dentro de la estructura orgánica de la Diputación cabe señalar la diferencia entre oficios y oficiales o cargos adscritos a ella. Dentro de los oficios del reino con una función esencialmente administrativa y documental, cabe señalar a los fedatarios de la Diputación: el notario extracto y el notario sustituto, quienes se encuentran al frente de todo el sistema administrativo. Ellos son los encargados de validar jurídicamente los documentos generados por orden de los diputados y los oficios en el ejercicio de sus competencias. En teoría, cada uno de los notarios tenía asignada la elaboración cada año de las series documentales derivadas de las funciones de la Diputación. El notario extracto, ayudado por el sustituto, como primeros oficiales fedatarios de la institución, estaba obligado a escriturar y validar los registros de ápocas de censales, salarios, comisiones y consultas, así como los registros de cartas misivas y los registros de insaculados en las bolsas de oficios del reino. ${ }^{145}$

La característica de fedatario público al servicio de los diputados aparece constantemente regulada en la compilación foral. El notario extracto testifica las escrituras emanadas y recibidas por los diputados y se dispone que incluso "pueda hazer, testificar y recibir todos los actos y escrituras concernientes a la diputación ante los diputados, aunque sean contractos $\mathrm{y}$ otros instrumentos y escrituras que peculiarmente competa testificar $\mathrm{y}$ recibirlos a los notarios del número de la ciudad de Çaragoça; el qual notario extracto tenga obligación de continuarlos en el registro de la dicha Diputación y entregarlos sacados en pública forma a los Diputados del Reyno mediante acto público». ${ }^{146} \mathrm{Su}$ actuación está totalmente sujeta a la potestad de los diputados, a quienes acompaña en la escrituración de los actos jurídicos. Ante los diputados tiene obligación de presentar cuantos escritos sean necesarios para la toma de decisiones en los asuntos ventilados en el consistorio. ${ }^{147}$

145 Savall y Penén (1866), vol. 2, p. 337.

146 Savall y Penén (1866), vol. 2, pp. 366-367.

147 Savall y Penén (1866), vol. 1, p. 402: «Que el notario de Diputados y subsituto de aquel sean obligados a presentar qualesquiere letras e hazer otros actos siempre que por los Diputados serán requeridos. Porque acaesce algunas vezes ser extractos en notarios de Diputados hombres que por temor o otros respectos dubdan de hazer presentaciones de letras y otras provisiones que emanan del Consistorio de los dichos Diputados del presente 
Naturalmente, la complejidad y el aumento de la actividad burocrática obligó a los diputados a incrementar el número de oficios administrativos con el fin de dar cauce al elevado número de escrituras y actos jurídicos documentados. Junto a los dos notarios, los escribanos de la Diputación, también notarios, aunque de menor rango, estaban obligados a «fazer los quadernos de la extractión de los officios del Reyno, e registrar e assentar en registro todos los actos, comissiones, cautelas, e otras escripturas que se havrá de escrivir y assentar en registro. E sea tenido de escribir la copia, siquiere libro de cuentas, que en cada un año se da al administrador de las generalidades del dicho Reyno [...]». ${ }^{148}$ Por su parte, el otro escribano de la Diputación tenía a su cargo la escritura del registro de intimas de censales y la actualización del cabreo de censales con el fin de determinar los cambios de titularidad de los censales cargados sobre las generalidades.

Sin embargo, uno de los oficios más interesantes dentro de la nómina de órganos administrativos es el secretario de la Diputación. Se erige en el verdadero agente dinamizador del trámite administrativo generando tipologías concretas, recogiendo a su vez los documentos dispersos por cada una de las escribanías productoras y encargándose de la custodia y la tramitación de las peticiones de acceso al archivo del reino. El secretario de la Diputación es, a su vez, el escribano principal, como se indica en el fuero que instituye su cargo en 1518. Ibáñez de Aoiz especifica que «el offiçio de secretario de la Dipputación havía estado siempre unido con el offiçio de notario extracto de los señores diputados y tenía a su cargo el escrivir y registrar las cartas de los señores diputados hasta el año 1592 [cuando] se cometió al escrivano principal de la Diputación el officio de

Reyno de Aragón; lo qual sino fuesse proveydo como conviene podría redundar en detrimento de las libertades del presente Reyno y daño de los regnícolas de aquél. Por tanto, su Magestad proveyendo a lo sobredicho, de voluntad de la Corte y quatro braços de aquella estatuece y ordena que los tales notarios y los substitutos dellos sean obligados de hazer las dichas presentaciones e intimaciones y testificar actos públicos de aquellas a qualesquiere personas y Iuezes de qualquiere estado, grado, preheminencia y condición sean, siempre y quando que por los dichos diputados les será mandado, so pena de privación de officio de Notario, y de todos los otros officios del Rey, del Reyno y de Universidades, en los quales estuviere insaculado, y que quede inhábil para obtener aquellos y otros qualesquiere y que no pueda ser insaculado en dichos officios perpetuamente y que para hacer dichas presentaciones e intimaciones los dichos notarios sean guiados devidamente y según Fuero».

148 Savall y Penén (1866), vol. 2, p. 337. 
secretario de los señores dipputados y el escrivir y registrar las cartas y hacer todos los despachos de los señores dipputados». ${ }^{149}$ De hecho, en las Cortes de 1592 se determinan con gran precisión las atribuciones del cargo de secretario, haciendo hincapié en el concepto de secreto documental. A partir de ese momento, las cartas y despachos emanados de los diputados son atribución del secretario y escribano principal de la Diputación, cargo que, como veremos, engloba generalmente también el de archivero, quedando a su cargo «La custodia de los processos que el notario extracto huviere actitado o concluydo en su año; y que el dicho notario extracto le havrá entregado conforme a la obligación que iuxta los actos de corte de las presentes cortes tiene de havérselos de entregar». ${ }^{150}$

Los conceptos de patrimonialidad, secretismo e inaccesibilidad de la documentación generada por las instituciones del Antiguo Régimen cobran especial relieve en este caso, por cuanto el secretario y escribano principal del consistorio aragonés agrupó frecuentemente en su persona los cargos de alcaide, secretario, conservador de las armas existentes en la armería del reino y archivero de la Diputación, vinculando así en un único cargo todos los derivados del concepto de custodia, salvaguarda y protección. Es decir, el sistema administrativo y documental se encuentra perfectamente delimitado en el seno de la Diputación. Las funciones de gobierno, administración, hacienda y justicia desarrolladas por la institución en virtud de sus competencias particulares y recogidas en la compilación foral, incluyen un interesante número de componentes. Por una parte se encuentra el equipo de gobierno representado por los diputados, al que se debe sumar la nómina de oficios del reino o cargos adjuntos a los diputados y encargados de diversas parcelas de la gestión de la hacienda interna de la Diputación, así como el recto funcionamiento de los oficiales de la corte del Justicia. Por debajo del entramado de gobierno subyace el extenso equipo burocrático activo, representado por la nómina de notarios y secretarios de la Diputación como canalizadores de la producción documental. Posteriormente, la documentación tramitada y finalizada se remite al archivo del reino, donde se custodiará en condiciones adecuadas de accesibilidad, siempre restringida por la atenta vigilancia de los diputados.

149 Lorenzo Ibáñez de Aoiz, Ceremonial..., B.U.Z., ms. 199, f. 159v.

150 Savall y Penén (1866), vol. 2, pp. 366-367. 


\subsubsection{Actividades}

Dentro de la génesis, escrituración, preparación y tramitación de los documentos de la Diputación del reino, se pueden establecer las siguientes actividades:

a) Proceso de elaboración manual de los registros y las escrituras por parte de los funcionarios.

b) Conclusión y remisión de las series mediante hoja de remisión al secretario de la Diputación, quien depositará los documentos en el archivo.

Cuando finaliza cada ejercicio anual, el cambio del equipo de diputados tiene su reflejo en los procesos administrativos desarrollados durante dicho mandato. Cada año, los notarios y escribanos encargados de realizar los registros encomendados elaboran un listado, a modo de hoja de remisión, donde se indican las tipologías concluidas correspondientes a ese año para que se recojan definitivamente en el archivo. Esta hoja, junto con los registros, es enviada al secretario de la Diputación, quien acepta haberla recibido mediante ápoca o recibo. Esta hoja aporta valiosos datos sobre las tipologías que se tramitaban cada año, los notarios actuantes y, en definitiva, es el reflejo del mecanismo de control documental seguido por la Diputación, puesto que delimita los momentos de creación, conclusión, remisión y custodia documental definitiva en el archivo del reino.

Sin embargo, el incumplimiento del procedimiento de entrega y remisión propició que en las Cortes de Tarazona de 1592 se hiciese mención expresa a la necesidad que los notarios y escribanos de la Diputación tenían con respecto a la conclusión y remisión de las escrituras y registros elaborados en sus escribanías. El remedio impuesto hacía referencia a la necesidad de entregar una fianza por parte de cada notario al comienzo de su ejercicio, en previsión de posibles negligencias administrativas en la finalización y entrega de los registros. ${ }^{151}$

151 Savall y Penén (1866), vol. 2, pp. 366-367: «Por experiencia se ha visto que de no aver tenido cuenta ni cuydado los Notarios extractos de la Diputación sino sólo con llevar sus salarios y derechos, acabado el tiempo de sus oficios, no han entregado ni entregan al Escrivano principal de la Diputación los processos que ante los Diputados en el año que han sido Notarios extractos, se han hecho, actitado y concluydo. Y así se pierden sin que aya cuenta, ni razón de ellos. Lo qual resulta en mucho daño del Reyno y de las partes inte- 
La entrega de los registros y escrituras afectaba a cualquier órgano generador de documentos. A esta disciplina documental se hallaban sujetos también los notarios de los brazos que asistían a Cortes, habida cuenta de que los diputados eran también los depositarios de dichos registros o procesos de Cortes, custodiados en los armarios del archivo del reino. Así, las Cortes de Zaragoza de 1678 establecieron que toda la documentación generada por los cuatro brazos debía remitirse directamente por parte del secretario de cada brazo a los diputados, quienes se encargarían de depositarla en el archivo. ${ }^{152}$

c) Control administrativo de documentos y de asuntos pendientes.

La gestión realizada por el equipo de diputados salientes al finalizar su mandato quedaba vinculada a los diputados entrantes merced al registro de las actividades pendientes y, sobre todo, a la indicación de los asuntos, procesos, escrituras y registros que todavía estaban en trámite en las diferentes instancias de poder, bien fueran desde instituciones aragonesas (Justicia, concejo, etc.) o bien monárquicas (Real Audiencia, consejos, etc.). Es decir, junto a la remisión de los documentos mediante una hoja de entrega, también se realizaba un estadillo de las cuestiones pendientes. El órgano encargado de esta función era el solicitador del reino, quien, por medio de la denominada cédula de los negocios del reino, asentaba los procesos pendientes y también los asuntos todavía por tramitar. ${ }^{153} \mathrm{La}$ memoria de

ressadas. Por tanto, su Magestad de voluntad de la Corte estatuye y ordena que el dicho Notario extracto de la Diputación en cada un año al fin del, antes de cobrar la minuta del salario de su oficio, aya y sea tenido y obligado de entregar mediante acto público al dicho Escrivano principal de la Diputación todos los processos que en el dicho año ante los dichos Diputados se huvieren actitado y concluydo y esto mediante inventario legítimo del cual aya de constar y se ponga en el Registro de los actos comunes de la Diputación del dicho su año, para que aya quien esté obligado a dar cuenta y razón de ello».

152 Savall y Penén (1866), vol. 1, p. 515: «los secretarios de los quatro braços no devan dar copia al notario de las cortes de los registros, sino que los originales que huvieren testificado los hayan de entregar y entreguen a los diputados del Reyno y éstos devan ponerlos en el archivo que está dentro de la Sala Real de la Diputación para que allí estén guardados con seguridad; y que sólo el notario de las cortes pueda sacar los actos que se pidieren. Otrosí estatuye y ordena que todos los registros y processos de la corte general y qualesquiere copias de ellos que hayan estado y estén en poder de los notarios que han sido y es de las cortes se devan entregar y entreguen a los diputados, los quales hayan de ponerlos en el archivo de el Reyno, que está dentro de la Sala Real de la Diputación para que allí estén custodiados; y que sólo el notario de las cortes pueda sacar los actos que se pidieren».

153 Registro de actos comunes del año 1636, A.D.P.Z., ms. 424, f. 3v. 
los negocios que tenía pendientes el reino a comienzos del ejercicio del año 1633 puede servir como ejemplo característico de dicha actuación de control administrativo:

Ante sus señorías pareció Francisco Berbegal, notario causídico de la presente ciudad, agente y solicitador de los negocios del presente reyno, el qual presente yo Martín de Sisamón, notario extracto y testigos avaxo nombrados dixo que cumpliendo con la obligación de su officio dixo que entregava y entregó a dichos señores diputados una memoria de los pleytos y negocios que el dicho y presente reyno tiene y de presente penden y están a su cargo para que sus señorías tengan sciencia y sabiduría dellos, la qual dicha memoria supplicava y supplicó a sus señorías la mandasen inserir en el presente registro. ${ }^{154}$

d) Trabajos extraordinarios: como la calendación de los libros de cuentas o la elaboración de índices y tablas de contenidos al principio de cada registro.

e) Actuaciones administrativas en la sala del consistorio. Éstas hacen referencia esencialmente a la entrega de documentos en las horas en que los diputados despachan sus asuntos. Correos que llegan con cartas de otras regiones, individuos que solicitan la cabrevación de censales y aportan pruebas documentales de su posesión, aperción de pliegos, etc., constituyen parte de las tareas documentales que se ventilan en la mesa de los diputados.

\subsection{Identificación de series documentales}

El análisis de tipos documentales destinados a identificar las series documentales constituye una de las operaciones archivísticas de mayor calado en el esquema organizativo documental y es la base imprescindible para el desarrollo del método de reconstrucción del orden original de los documentos.

De hecho, uno de los pilares básicos sobre los que se asienta la organización de los documentos de archivo, y muy especialmente la clasificación documental, es el análisis de los tipos documentales producidos por

154 A.D.P.Z., ms. 407, f. 4r-5v. 
la institución. Este método de análisis documental se inspira en una serie de trabajos básicos para su realización: ${ }^{155}$

a) Análisis y fijación de caracteres externos.

b) Análisis y fijación de caracteres internos, para determinar:

- Unidad administrativa productora, que centraliza la gestión del documento y es responsable del trámite que debe seguir.

- Origen funcional: se indica la función de la que deriva el documento, la actividad concreta por la que se produce y el trámite del proceso generador, atendiendo a la legislación y normativa que regula su génesis

- Data crónica y tópica

- Tenor documental o modo de disponer la información según un canon diplomático.

- Asunto del que trata.

c) Denominación y definición del tipo documental.

d) Representación de las series en el cuadro de clasificación propuesto.

A pesar de los avatares sufridos por la documentación de la Diputación del reino de Aragón, hemos acudido a sus propias fuentes archivísticas para averiguar la naturaleza y las características de las series que constituyen la producción de la institución, cuyos datos hemos contrastado con la información suministrada por las fuentes jurídicas y normativas. Así, hemos encontrado que, junto a tipologías perfectamente descritas y presentes en todo el procedimiento administrativo de la Diputación, existen series documentales que apenas se han conservado hasta nuestros días e incluso otras de las que sólo sabemos de su existencia por medio de fuentes indirectas. Por tanto, por una parte, constatamos que las series conservadas con mayor o menor fortuna hasta hoy permiten, por su riqueza informativa, un análisis detallado a partir de los datos suministrados por la estructura y contenido de la propia tipología consultada; y por otra parte, tenemos constancia de que la Diputación generó y custodió tipologías de las que apenas han quedado rastro, de modo que para realizar un

155 Theodore R. Schellenberg (1961). Grupo de Archiveros Municipales de la Comunidad de Madrid (1997). Pilar Gay Molins (1995), pp. 11-12. 
análisis que incluya una definición, origen, tramitación y alcance de la serie ha sido imprescindible acudir a fuentes esencialmente indirectas y complementarias. En cualquier caso, el proceso de identificación de las series documentales, que concluye con la elaboración del cuadro de clasificación, se basa fundamentalmente, sin perjuicio del interés y exhaustividad de referencias históricas alternativas y complementarias, en el estudio empírico de las propias tipologías; en último término, se trata de validar la afirmación de que «los propios documentos y los instrumentos de descripción antiguos son la mejor fuente de información». ${ }^{156}$

Se presentan las series en orden alfabético, que se completa en el siguiente apartado con el orden sistemático propio del cuadro de clasificación.

\section{Alacena del cronista}

Más que una serie documental, este conjunto de documentos estuvo compuesto por la colección de cuantas informaciones y datos, manuscritos o impresos, fueron necesarios para el oficio de cronista del reino, desmembrando documentos de otros archivos, copiando muchos otros y entregando para su custodia en esta "alacena» los cuadernos originales de trabajo que los cronistas tenían obligación de entregar para formar los Anales de la Corona de Aragón. Por tanto, el material documental coleccionado era muy heterogéneo, incluyendo documentos originales traídos por Zurita de otras latitudes, copias de pergaminos y documentos medievales, extractos de Anales, ejemplares incompletos de éstos, etc. ${ }^{157}$

\section{Bastardelos de actos comunes}

Serie de gobierno. Disposiciones emanadas. Esta serie documental constituye el escrito preparatorio o minuta de los registros de actos comunes. En los bastardelos se anotan por menudo y sintéticamente los actos tratados para pasarlos al registro formal. Estos bastardelos son unos cuadernillos anotados por los notarios del reino. En defecto de los registros de actos comunes, surtían el mismo efecto jurídico. Actualmente existen muy pocos ejemplares de dicha serie, debido probablemente al conocimiento

156 Miguel Ángel Esteban Navarro (1997).

157 Sobre la alacena de Zurita, véanse J. de Salas Bosch (1944). Ángel Canellas López (1983), (1971) y (1984). 
que el último archivero de dichos fondos documentales, don Santiago Terreros, tenía de ellos. Este conocimiento habría propiciado que en la situación de asedio militar sufrida por Zaragoza se decidiese a centrar los esfuerzos de salvaguarda documental en las series más representativas de la institución y no en los bastardelos, escritos preparatorios de los solemnes actos comunes.

\section{Bastardelos de inquisidores de procesos}

Serie de justicia. Al igual que los bastardelos de los registros de actos comunes, los inquisidores de procesos realizaban un borrador documental donde anotaban por menudo los actos y diligencias necesarios para desarrollar los procesos de su competencia: los procesos de denunciación. Una vez finalizados, se remitían al archivo con el resto de las series documentales, como revela una orden de remisión fechada en julio de 1614:

Después de hecho lo sobredicho, los dichos día, mes, año y lugar, los dichos señores diputados, para fin y effecto de custodiar y guardar el processo y bastardelo de enquesta y denunciación hecho contra los señores doctores Francisco de Mirabete y Juan Francisco de Salazar, abrieron el archiu de dicha dipputación, en el qual presente yo, Joan de Morlanes los testigos infraescriptos pusieron un proceso intitulado los dipputados del presente reyno de Aragón contra los doctores micer Francisco de Miravete y Juan Francisco de Salazar y el bastardelo de dicho proceso y aquéllos a saber es dichos procesos y bastardelo en dicho archiu dexaron y pusieron y dicho archiu después de lo dicho cerraron. ${ }^{158}$

\section{Bulas y privilegios}

Serie de gobierno. Disposiciones recibidas. Estas tipologías documentales compuestas por las bulas de aprobación, confirmación, breves pontificios, privilegios, buletos, etc., suministraban la protección jurídica emanada de la cancillería pontificia y regia. Estos documentos hacen referencia a la protesta por el nombramientos de cargos, como el del conde de Mélito, lugarteniente del reino (1554), a concesiones a los señores temporales de las décimas de los musulmanes convertidos (1524), etc.

Constituyen en su conjunto la más preciada confirmación de los derechos y privilegios recibidos por el reino de Aragón y la institución que lo

158 Registro de actos comunes del año 1614, A.D.P.Z., ms. 334, f. 71 r. 
representa en sus relaciones con las más altas instituciones de la cristiandad y de la monarquía hispánica. Buena parte del arsenal de autoridad que ampara a la Diputación se deriva de estas tipologías documentales solemnes.

\section{Cabreos de los censales}

Serie de hacienda. Ingresos extraordinarios. Los censales emitidos sobre el General debían aprobarse en las Cortes. Una vez aprobada la cantidad de censales y el interés, se debía hacer pública la emisión y las condiciones para que cualquier persona pudiera invertir. El inversor acreditaba el número de censales invertidos, la fecha en que debía percibir los intereses anuales y la cantidad a percibir. Todo ello era anotado en los cabreos o registros de los censales, donde se hacía constar cada uno de los censales en vigor, las alteraciones por ventas, herencias, donaciones, etc. Indica Sesma que «el cabreo recoge cada uno de los censales en vigor, con las sucesivas alteraciones que experimenta, por ventas, herencias, etc.». ${ }^{159} \mathrm{De}$ este registro se hacían dos copias. ${ }^{160}$ Cada uno de los censales y sus circunstancias integraban las partidas del libro, que era ordenado por meses. Encabezaba el titular del censal, anotando la cantidad y la pensión o interés que se le debía abonar. A continuación, cualquier cambio se iba anotando por diferentes manos, conforme se iba produciendo.

Cuadernos de deliberaciones de la junta de sisas

Serie de hacienda. Sisa. Junto a los registros de ápocas del servicio de las sisas, la gestión de este impuesto especial se apoyaba en una serie de decisiones tomadas por un conjunto de individuos comisionados y elegidos para formar las denominadas juntas del servicio de sisas. Esta tipología constituía un registro donde se anotaban todas las actuaciones de las denominadas juntas para el servicio ofrecido al rey en concepto de sisas. Cada entrada se ordenaba cronológicamente indicando el día de la semana en que se había hecho la deliberación. Se iniciaban con la lista de los componentes de estas juntas, generalmente miembros de los cuatro brazos con asistencia a Cortes, diputados o no, y nombrados por el rey y las Cortes generales y cuatro brazos de ellas.

159 José Ángel Sesma (1977), p. 127.

160 Registro de actos comunes de 1507, A.D.P.Z., ms. 98, f. 78v. 
Cuadernos de las extracciones de los oficios

Serie de gobierno. Control del equipo de gobierno. Está muy relacionada con las matrículas de insaculados, puesto que el paso siguiente a la elección era la indicación también por escrito de los nombres de los elegidos para cada oficio, formando así los cuadernos de las extracciones de los oficios. Estos cuadernos estaban bajo la responsabilidad del secretario de la Diputación: «la extractión y juramento de los adbogados y procuradores del Reyno la continúan el notario extracto en el registro de los actos comunes y el secretario en el registro que haçe de las extractiones de oficios del Reyno». ${ }^{161}$

\section{Cuadernos del pagador de los tercios}

Serie de hacienda. Gastos extraordinarios. La contribución del reino al sostenimiento de un contingente armado capaz de integrarse en un ejército organizado por la monarquía hispánica incluía a un número oscilante de hombres con los que se intentaba contentar las necesidades militares cada vez más constantes y acuciantes. En este sentido, la Diputación fue la encargada de organizar tercios durante el siglo XVII. Como indican Solano Camón y Sanz Camañes, «tanto las arcas del reino aragonés como el erario de sus municipios habrían de verse abocados a proporcionar a la Corona, durante los siglos XVI y XVII, una serie de recursos — préstamos y donativos— con los que ésta pudiera contar ante situaciones en las que la urgencia del momento no hacía posible la reunión de cortes para su solicitud, o cuando el pago de lo comprometido en las mismas no salvaba las expectativas de la Corona». ${ }^{162} \mathrm{El}$ pago regular a los soldados integrantes era administrado por el llamado "pagador de los tercios». Junto a los libros de cuentas del administrador del general, estaban sujetos al control contable de los inquisidores de cuentas: «llaman al pagador de la gente de guerra para que dé cuenta y él la da con un libro que entrega cada año y como es cuenta ordinaria y de salarios tasados, leydas las partidas del cargo y descargo y la resta que le quedó del año de antes y que conforma con el libro de cuentas de aquel año».

En general, los registros del pagador de la gente de guerra incorporan diversas partidas económicas referidas a los ingresos efectuados por orden del arrendador de las generalidades. Junto a ellos, se consigna el pago de cada uno de los integrantes de la milicia en función de su rango y gradua-

161 Lorenzo Ibáñez de Aoiz, Ceremonial..., B.U.Z., ms. 199, f. 71v.

162 Enrique Solano Camón y Porfirio Sanz Camañes (1998), p. 239. 
ción. Las ápocas o recibos de pago son testificadas ante el notario extracto de la Diputación. Junto a los ingresos y ápocas de pago se escrituran las pólizas o pagos necesarios, ordinarios y extraordinarios, para el sostenimiento del contingente militar. También el pago de los correos con órdenes e informaciones de naturaleza castrense son anotados en dichos cuadernos como partidas incluidas en el apartado de gastos. Finalmente, el autor de los cuadernos solía realizar un estadillo de los soldados que faltaban por aportar a los municipios (universidades) del reino, con el fin de completar los cuadros de milicia. Así, al final de algunos de estos registros se encuentra un listado de localidades con dos columnas bien delimitadas: «les toca» y «faltan». Por ejemplo, en 1646, según el repartimiento efectuado por los diputados, en uno de estos registros constaba que Escatrón tenía que aportar dos soldados y eran dos los que faltaban; es decir, todavía no habían reclutado a nadie. Por contra, a Zaragoza le tocaba un total de 300 soldados y faltaban únicamente trece para completar dicho número. ${ }^{163}$

\section{Firmas}

Serie de gobierno. Disposiciones recibidas. La firma de derecho constituye una garantía jurídica emanada de la corte del Justicia. ${ }^{164}$ Gregorio Colás la define como «aquel recurso expedido por la corte del Justicia que obligaba a paralizar toda acción emprendida contra una persona, institución, territorio..., hasta que se demostraba que era conforme a fuero». ${ }^{165} \mathrm{El}$ instrumento de firma procedía de un proceso seguido en forma privilegiada según los fueros del reino, que, notificado a las dos partes, no podían proceder contra su contexto en manera alguna; se obligaba por este medio a que incluso las personas exentas acudiesen al tribunal secular a seguir su justicia. Y si en parte o en todas contravienen, son llamados fractores de firma y, como a tales, se procede contra ellos hasta ocupar las temporalidades a los prelados, comunidades y demás personas eclesiásticas. La firma consiste, por tanto, en un documento jurídico producido por el Justicia de Aragón que remite a terceros, en este caso a los diputados. Por consiguiente, su reunión en el fondo de la Diputación del reino de Aragón las convierte, atendiendo a sus asuntos, en una serie de gobierno, ya que con-

163 A.D.P.Z., ms. 452, f. 265 r.

164 Véase la obra de Ángel Bonet Navarro (1982), pp. 27-31.

165 Gregorio Colás Latorre (1998), p. 67. 
tienen una precisa delimitación de los derechos y privilegios de sus receptores, actuando como resguardo, por lo que pertenecen al grupo de tipologías documentales sustentadoras del poder de las cancillerías. En 1749 se contabilizaron hasta 229 firmas antiguas en los índices del archivo, aunque sólo habían llegado hasta entonces 24 completas.

\section{Fogajes}

Serie de administración. Registro y control de población. Constituye una tipología documental de sumo interés para la investigación demográfica del reino de Aragón. Establecidos como instrumentos necesarios para el control fiscal de la población, su elaboración corría a cargo de comisiones habilitadas a tal efecto, que recorrían todos los lugares del reino para determinar su número de habitantes. La conservación y custodia de estos registros quedaba bajo la supervisión directa de los diputados en el archivo del reino: «De las quales [investigaciones] se hagan actos, y se remitan a dichos obispos, para que se haga un cabreo de dicha investigación y fogueación; y aquél signado por el notario de las cortes, se guarde perpetuamente en el archivo del presente Reino; y conforme a dicho cabreo, tengan obligación dichos diputados de hazer el repartimiento que a cada universidad tocare [...]». ${ }^{166}$ En el archivo del reino se custodiaban los fogajes correspondientes a los años $1429,{ }^{167} 1459,1467,1489,{ }^{168} 1495,{ }^{169} 1512$ y $1637 .{ }^{170}$

166 Savall y Penén (1866), vol. 2, p. 477.

167 Jerónimo de Blancas, Sumario y Resumario de las Cortes celebradas en Aragón, Zaragoza, B.U.Z., ms. 97: «Cortes de Valderrobres de 1429». Un fragmento del fogaje aprobado en estas Cortes se halla publicado por J. Á. Sesma y E. Sarasa (1976). Vid. en general Isabel Falcón Pérez (1990), pp. 282-283.

168 Fogajes de Aragón, 1489-1491, A.D.P.Z., leg. 774. Vid. María Isabel Falcón Pérez (1987).

169 Fogaje del año 1495, A.D.P.Z., ms. 660. Publica Antonio Serrano Montalvo (1995). Vid. igualmente A.D.P.Z., mss. 82 y 84: Fogajes ordenados en las Cortes de Tarazona, 1495. Vid. además R.A.H., ms. 9/5194, que contiene la copia hecha por Manuel Abella del repartimiento de sisas que se halla en el archivo de la Diputación antigua de Aragón, intitulado Lo libro del conto de las sisas indutas del Reyno de Aragón, por tiempo de dos años, que empiezan en el de 1489 y acaba en el de 1491. En el colofón de esta copia, el autor dice: «Copia de la advertencia de los foages, almario 28, n. ${ }^{\circ} 2$. Libro del número de los fuegos de cada uno de los pueblos del Reyno, según la investigación general, fecha de ellos, por los investigadores nombrados por el Rey nuestro señor y la corte».

170 En A.D.P.Z., leg. 1444, se recoge un censo de población correspondiente al año 1647, pero no se encuentra el de 1637 aquí consignado. Tal vez se trate de un error en la transcripción de la fecha. Vid. Porfirio Sanz Camañes (1991). 
Índices y rúbricas del archivo

Serie de administración. Archivo. La ordenación de los documentos generados por la Diputación del reino constituye una función administrativa y documental que se desarrolla en torno al archivo como división operativa de toda la institución. La segunda fase del sistema documental, encarnado en los procedimientos de custodia y acceso, requiere de instrumentos descriptivos que faciliten la constancia de los documentos y el acceso a éstos como recurso informativo. Los diputados aragoneses, conscientes del valor de la organización de las escrituras y de su correcta descripción, fomentaron la realización de inventarios, índices y resúmenes para localizar los documentos del archivo del reino. Como se indica extensamente en el apartado correspondiente a los instrumentos de descripción documental, la descripción de los documentos del archivo corresponde a una voluntad surgida de la estrategia archivística desplegada por los diputados, donde los documentos se encuentran simultáneamente al servicio del gobierno, la administración y la historia del reino representada por la labor de los cronistas oficiales. ${ }^{171}$ Esta serie descriptiva se custodiaba en el armario número 1 del archivo.

\section{Libros de cuentas del general del reino}

Serie de hacienda. Generalidades. La constancia documental de la administración de la hacienda del reino se refleja en los libros de cuentas del general o libros negros (por el color de su cubierta), que registran el balance de cada ejercicio económico. Los libros de cuentas están íntimamente relacionados con el resto de registros de naturaleza hacendística y fiscal. Así, los libros de cuentas anotarían los gastos pagados por el administrador y ordenados por los diputados en los registros de actos comunes mediante las cautelas u órdenes de pago, mientras que los registros de ápocas de censales, comisiones y salarios anotarían el recibo o albarán de las cantidades recibidas por los interesados.

Como indica Sesma, la estructura documental de estos libros es muy uniforme. En primer lugar, el administrador anota los ingresos o receptas y seguidamente los gastos o datas, atendiendo a los siguientes conceptos:

171 Diego Navarro Bonilla (1999c). 
salarios, abono de pensiones y gastos extraordinarios. El libro se cierra con el resumen de cuentas con el saldo definitivo, a favor o en contra, y los encautes o advertencias hechas por los inquisidores de cuentas, entendidas como instrucciones económicas para el año siguiente. ${ }^{172}$ Los titulares de este oficio, cuyas funciones ya han sido delimitadas en el apartado que analiza su actividad, actúan como inspectores hacendísticos, encargados de velar por el correcto gasto de la hacienda del reino, controlando que se emplean los fondos públicos de la Diputación para afrontar los gastos estipulados por fuero. Porfirio Sanz analiza esta tipología documental y de nuevo insiste en sus características formales y de contenido. ${ }^{173} \mathrm{El}$ procedimiento de confección de los libros de cuentas del general del reino se detalla en las propias capitulaciones establecidas entre el administrador y los diputados. El primero tiene la obligación de garantizar la validez de todo el proceso al entregar a los diputados

\begin{abstract}
Buenos y leales cuentos e de continuar en sus originales las receptas de todos los drechos del general, e restituyr los albaranes e otras cosas necessarias a la clareza e verificación de los contos sin frau e art alguna e por escusar qualquiere manera de frau los arrendadores sean tenidos dar a los collidores de la tavla de Caragoça e de todas las otras tablas de Aragón, libros cosidos en cobiertas de pergamino las cartas de los quales sean calendadas de mano del notario del Reyno por letras extensas e no abreviadas primera, segunda tercera, e los cojedores sean constituydos con sagrament e omenaje sentencia de excomunicación de escrivir en los dichos libros enteramente sin frau todas las receptas e contos que tocarán a ellos e a cada uno dellos en la parte suya con los quales libros se hayan a dar conto a los diputados en qualesquiere de los casos susodichos e sean tenidos los arrendadores poner en los officios de sobre cojedores e guardas personas ydóneas y fieles. ${ }^{174}$
\end{abstract}

A finales de abril, poco antes de que el nuevo consistorio comience su mandato, el administrador presenta las cuentas del libro en el transcurso del denominado definimiento de cuentas, donde el testimonio documental juega un papel preponderante y la garantía del control se ejerce por la presencia de los inquisidores de cuentas o contadores, como oficios del reino responsables del control económico. De hecho, se trata de comprobar estas cuentas con el apoyo de cuantas tipologías documentales y regis-

172 José Ángel Sesma (1977), pp. 105, 149 y 169.

173 Vid. además P. Sanz Camañes (1992), pp. 479-490.

174 Registro de actos comunes del año 1526, A.D.P.Z., ms. 124, f. 49r-49v. 
tros se hallen en el archivo del reino, y concluir que los gastos efectuados se corresponden con una voluntad real y documentada de los diputados:

Y a mayor descargo de dichos administradores, les hizieron fe y ocular ostensión de un libro de pliego de forma mayor, con cubiertas de cuero negro, en el qual dixeron estavan continuadas las datas y receptas por ellos como administradores sobredichos hechas; el qual libro se intitula libro de conto de las pecunias pertenecientes al general del Reyno de Aragón encomendadas a nosotros, Gabriel Çaporta, Felippe Estevan mercaderes y ciudadanos de la ciudad de Caragoça. ${ }^{175}$

El proceso consiste en una comprobación y cotejo de todas las partidas contenidas en este libro con las partidas de los registros donde se anotan las órdenes de pago o cautelas por parte de los diputados. En suma, se trata de comprobar que a cada una de las entradas del libro de cuentas del general corresponde su orden de pago extendida por el consistorio de los diputados. Las partidas del libro de cuentas del general se comprueban y contrastan con las cautelas y órdenes de pago de los diputados anotadas en los registros de actos comunes (el acto que ordena el pagamiento) y con los registros de ápocas de pensiones de censales y salarios (recibo del interesado de que ha cobrado el dinero). En los libros de cuentas está anotado el pago real efectuado por el propio arrendador en cada ocasión. En el definimiento de cuentas de 1582 se especifica claramente el papel que otros registros tienen para gestionar el presupuesto de la Diputación.

El administrador debía presentarse ante el arrendador en la sala de San Jorge de la Diputación, «el qual provehe a los contadores de tinteros, salvaderas, tixeras, cuchillos, tinta, plumas y papel para pasar las quentas». Más tarde acudían los diputados entrantes y los salientes para comenzar a pasar las cuentas. En primer lugar era necesario traer los libros donde los administradores habían anotado las cuentas y pagos de su ejercicio. Entonces el escribano principal de la Diputación lee las partidas en voz alta y se comprueba que cada entrada coincide con las ápocas de gastos hechos por mandato de los diputados. A continuación, un portero va cosiendo las ápocas o recibos de estos gastos. Los contadores advierten entonces las partidas dudosas.

175 Registro de actos comunes del año 1566, A.D.P.Z., ms. 199, f. 5 v. 
En primer lugar, para justificar el desembolso por los salarios y cargos ordinarios de la Diputación, es preciso acudir a los registros de asistencias de los propios diputados, para descontar del salario total los días en que habían vacado:

Otrosí dizen que han visto y reconosçido el libro de las asistençias de los señores diputados próxime passados en el qual an allado y hallaron que el illustrísimo señor don Blasco de Alagón, a faltado un día y Joan de Arnedo tres días; adviértenlo para que los administradores cobren las dichas faltas de las ápocas de sus officios, para que en la cuenta que se dará en el mes de junio del año mil quinientos ochenta y tres se aga el dicho arrendador cargo dellas.

Otros registros, como los libros de cuentas de la gente de guerra, registros de actos comunes y libros de cuentas de ejercicios anteriores, apoyan todo el proceso de revisión de cuentas: «lo mismo se dize del arrendador que de los señores diputados. [...] Si para pasar estas quentas los contadores an menester los libros de cuentas viejos y qualesquiere registros cabreos, consultas y libros de la hacienda del Reyno, se les an de entregar los detenedores de ellos»: ${ }^{176}$

Otrosí dizen que los dichos señores contadores que han visto y reconocido el libro de la gente de guerra que el Reyno paga en persecución de bandoleros y que en él queda deviendo Miguel de la Foz, pagador para azer la paga de los meses de março, abril y mayo próxime pasados tres mil doçientas setenta y tres libras, dos sueldos y onze dineros jaqueses. Dixeron que para fin y efecto de sacar los libros y registros para el tribunal de los señores contadores que son los registros de los años mil seiscientos quarenta y dos, quarenta y tres, cinquenta y dos, cinquenta y tres, cinquenta y quatro, cinquenta y cinco, cinquenta y seis, cinquenta y siete, cinquenta y ocho y mil seyscientos cinquenta y nueve, mandaron se habriese el archivo y avierto aquél se mandaron sacar y sacaron los dichos registros y libros negros que quedaron por memoria en el libro que está en dicho archivo para escrivir lo que se saca dél, los quales dichos libros y registros, dichos señores diputados los dieron y entregaron a dichos señores contadores y se quedaron con ellos para fin y effecto de pasar y averiguar las quentas del presente año y hecho lo sobredicho, dichos señores diputados mandaron cerrar dicho archivo. ${ }^{177}$

Los inquisidores de cuentas informan y advierten mediante los encautes de ingresos que deben ser cobrados, de cuentas atrasadas y, en definitiva, su gestión agiliza todo el proceso de control hacendístico necesario, llevado a

176 Lorenzo Ibáñez de Aoiz, Ceremonial..., B.N.E., ms. 2922, f. 40r-45r.

177 Registro de actos comunes de 1662, A.D.P.Z., ms. 516, f. 9r. 
cabo por la Diputación. ${ }^{178}$ De hecho, estos contadores (o inquisidores de cuentas) constituyen la nómina de oficios directamente relacionados con el control de la hacienda y de la gestión económica de los diputados: «Conocen los Señores Inquisidores de Cuentas si algún diputado ha tomado dinero o dádiva de qualquiere especie por insacular en los oficios del Reyno». ${ }^{179}$

Una vez anotadas todas las partidas correspondientes a gastos e ingresos, comprobado su rigor y ejercido el control definitivo por los contadores en el proceso de definición de cuentas, el administrador hace entrega de los libros negros o de cuentas a los contadores y éstos a los diputados, quienes definitivamente ordenan remitirlos a su armario correspondiente en el archivo del reino. ${ }^{180}$

\section{Libro de expensas menudas}

Serie de hacienda. Gastos extraordinarios. Los pagos extraordinarios que los administradores deben efectuar, pero sin órdenes de pago expresas por los diputados, aunque el monto pecuniario sea pequeño, se recogen en los libros registros de expensas menudas (gastos de poca importancia), que

178 Registro de actos comunes de 1582, A.D.P.Z., ms. 245, f. 11r: «Otrosí diezen que por advertimiento de los dichos señores contadores se dize que Luys Ganareo, librero del Reyno, tiene doze juegos de la Corónica del rey Cathólico en su poder para los vender a utilidad del reyno y pidiendo razón a los señores dipputados passados, lo que han hecho en la cobrança y cuenta deste librero, han respondido y responden que le han mandado dar cuenta y por ella ha mostrado que los señores diputados le deven más de lo que valen dichos doze juegos de la dicha Corónica que se le encomendaron y que para ver la dicha su cuenta nombraron en contadores a Jerónimo López y Jerónimo Andrés y que el dicho Jerónimo López vio la cuenta y les hizo relación que las partidas que pone el dicho librero del reyno que fue dipputado el dicho Jerónimo López, las tiene por ciertas y quanto a las demás que no tiene memoria por no ser de su tiempo y vista, su respuesta la ha mandado llamar al dicho librero».

179 Del officio, poder y jurisdición de los Ilustrísimos Señores Diputados del Reyno de Aragón, B.N.E., ms. 8380, f. 263.

180 Registro de actos comunes de 1658, A.D.P.Z., ms. 503, f. 3r-3v: «Pareció don Francisco Sanz de Cortés, administrador y arrendador general de las generalidades del presente Reyno, el qual satisfaciendo a la obligación que tiene como administrador sobredicho, dio y entregó en poder de dichos señores contadores dos libros negros de las cuentas de las generalidades del dicho presente Reyno de los años próxime pasado de mil seyscientos cinquenta y ocho y del presente de mil seyscientos cinquenta y nueve, que como administrador tiene obligación de dar según el acto y la costumbre de dichas cuentas y los demás recados acostumbrados y que conforme a fuero y actos de corte tiene obligación de dar, librar y entregar los quales dichos señores contadores recivieron en su poder y otorgaron haver recibido». 
deben ser igualmente controlados por los inquisidores de cuentas en el momento de la definición de las cuentas: «Item que todas las póliças de las obras que se farán en las cosas de la Diputación e los otros gastos que los diputados farán de espensas menudas sean assentadas e registradas en un libro, que para esto se fará, porque por el dicho libro e por las dichas póliças los contadores vean al tiempo de las cuentas, los gastos que en dichas espensas menudas los diputados havrán fecho. El qual libro, passadas las dichas cuentas se ponga en los armarios de la instancia baxa». ${ }^{181}$

\section{Libros de intimas de censales}

Serie de hacienda. Ingresos extraordinarios. Estos registros se componían de las anotaciones acerca del cambio de la titularidad de los censales o deuda pública emitida por la Diputación sobre el impuesto de las generalidades. Estos cambios en la propiedad de un censal debían ir acompañados de los documentos que avalasen tal circunstancia, lo que era comprobado por los abogados del reino. En suma, constituyen un instrumento de control fiscal sobre la propiedad de los censales. Sin embargo, los intereses que deben abonarse en concepto derivado de la rentabilidad del censal se gestionan mediante otra serie documental: los registros de ápocas de censales. Sesma ilustra la necesidad de contar con instrumentos documentales necesarios para dicho control, al indicar lo siguiente:

El propietario de un censal podía disponer libremente de él, venderlo, donarlo como limosna, legarlo como herencia, etc. Siempre que cambiaba de titular, debía intimarse al administrador y al notario del registro, para que se procediera a realizar la correspondiente anotación. Todas estas operaciones, que eran preceptivas para que el nuevo propietario pudiera reclamar sus derechos debían hacerse ante notario, presentando las pruebas necesarias siendo los diputados los que comprueban la veracidad de los alegatos. ${ }^{182}$

\section{Libro inventario de los bienes de la Diputación ${ }^{183}$}

Serie de administración. Patrimonio. Es el registro ordenado de los bienes muebles existentes en el palacio de la Diputación, atendiendo a partidas relativas a las jocalias, muebles, libros, objetos de escritorio y cuantos

181 Savall y Penén (1866), vol. 2, p. 340.

182 José Ángel Sesma (1977), p. 129.

183 Inventario de los bienes de la Diputación, años 1593-1616, ms. 270 del A.D.P.Z. 
objetos inventariables se encontrasen físicamente en la sede del reino. También en este libro inventario se anotaba la gestión de los libros impresos por el reino. Las entradas y salidas de éstos desde la librería o «archivo alto» se hacían constar mediante partidas específicas controladas por los inquisidores de cuentas o contadores:

Uno de los contadores toma a su mano el libro del imbentario de los vienes del Reyno y con aquél sube a la librería con el libro del Reyno y el notario extracto y allí quentan los libros que están en ser y el que los tiene a su cargo da quenta de los vendidos y entrega la cantidad que a sacado y se le pasa su cuenta, páganle a sueldo por libro de lo que a sacado y también con el imbentario pasan la cuenta con el que tiene a su cargo las jocalias y cosas de la capilla de la Diputación y la sala de las armas y de los demás bienes que ay en la Dipputación y de la cassa del Reyno y de la Iglesia de San Juan de los Panetes $[\ldots]{ }^{184}$

\section{Libro de las tablas de villas}

Serie de hacienda. Generalidades. Es el registro que realizan los encargados de recopilar las cantidades de dinero recaudadas en concepto de entrada y salida de mercancías por las fronteras del reino. Este libro se compone de las anotaciones de las cantidades ingresadas que corresponden a cada uno de los albaranes extendidos como justificante de que un mercader ha satisfecho el pago por la mercancía introducida o extraída. El contraste entre estos albaranes, como documento fedatario de la recepción por parte del funcionario del general, y las partidas del libro de las tablas delata irregularidades en el cobro, solventadas mediante procesos civiles conducentes a resarcir la cantidad defraudada mediante la incautación y venta de los bienes del oficial responsable. La comprobación y lectura de dichos registros de administración del impuesto se percibe frecuentemente en la documentación de la Diputación. Como ejemplo, en agosto de 1630 los diputados solicitaron al tablajero y sobrecollidor de la villa de Sádaba la inspección de su registro «Por cosas que convienen a los servicios de este consistorio y beneficio de la justicia». Para ello, comisionaron a Marco Baltasar Zapata, portero de los diputados, para recoger el libro y llevarlo a Zaragoza, «a quien entregará vuestra merced dicho libro con acto para que se restituya quando convenga a su tiempo y importa

184 Lorenzo Ibáñez de Aoiz, Ceremonial..., B.U.Z., ms. 199, f. 63r. 
mucho que sin ninguna dilación se ponga en execución este orden del consistorio». ${ }^{185}$

\section{Matrículas de insaculados en los oficios del reino}

Serie de gobierno. Control del equipo de gobierno. Desde las Cortes de 1446 , los oficios que componen cada uno de los equipos de gobierno del consistorio aragonés son elegidos mediante un método mixto de selección e insaculación o elección por sorteo. La relación de los posibles candidatos para cada uno de los oficios se realiza mediante la escrituración de los nombres en un registro llamado libro de la matrícula, por parte de cuarenta y ocho personas comisionadas por las Cortes para proponer a los candidatos que serán extractos.

La matrícula de los insaculados para el sorteo de los oficios del reino eran unos libros en folio que guardaba el notario de las Cortes, donde se anotaban los candidatos que previamente habían probado documentalmente su calidad respectiva, según perteneciesen a uno de los cuatro brazos. ${ }^{186}$ Posteriormente, el notario de los diputados hace los teruelos o redolinos donde se apuntan los nombres de los candidatos. ${ }^{187}$ Éstos son extraí-

185 Registro de cartas, años 1629-1635, A.D.P.Z., ms. 394, f. 58v.

186 Savall y Penén (1866), vol. 2, p. 382: «Para remediar el abuso que ha havido y hay en la diputación, en el modo de insecular en los oficios della a los cavalleros y hijosdalgo [...] que al tiempo de haverse de hazer la tal insaculación, a los diputados del Reyno les haya de constar por decisoria o privilegio, acto de sentencia o firma casual, titular o possessoria, proveyda por lo menos con seys testigos, que concluyan de diversos actos possessorios distintos de padres y agüelos, como aquellos son cavalleros o hijosdalgo. Y assí mesmo, los tales que se hayan de insecular en dichas bolsas, traygan provança del Iusticia y iurados de la universidad en donde tuvieren su domicilio, por la qual conste, como es hijodalgo de naturaleza, de la qual provança se haya de hazer fe en el registro de la Diputación $[\ldots] »$.

187 Savall y Penén (1866), vol. 2, p. 318: «\& que con semblant metrícula de la sobredicha, cerrada \& sillada, sea librada por el dicho notario de la cort a Iayme Sánchez, notario de los diputados [...] e sean tenidos por virtud del dicho juramento de tomar a sus manos las claves del archiu \& de las caxas do están las bolsas de los teruelos de los dichos officios recondidas e abrir el dicho archiu y las dichas caxas e abrir e reconocer las dichas bolsas, y fazer los redolinos de los que son nombrados a los dichos officios en las dichas metrículas y poner cada uno en su bolsa juxta las dichas metrículas y servando aquellas, y después de puestos los teruelos en ellas, según dicho es, cerrarlas y sellarlas y tornarlas a las dichas caxas $[. .$.$] con esos candidatos y luego los diputados hacen los teruelos; los meten$ en las cajas y las cierran». 
dos al azar de una bolsa: es decir, se sigue el procedimiento de insaculación para determinar los encargados de los diversos oficios del reino para cada ejercicio anual.

\section{Procesos de consultas}

Serie de hacienda. Gastos extraordinarios. A pesar de que los diputados tienen asignada una cantidad para poder sufragar gastos extraordinarios englobados en la ambigua denominación «beneficio y utilidad del Reino», sucedía que en ocasiones era necesario gastar cantidades no establecidas por fuero. Como medio eficaz para abreviar todo el procedimiento y no esperar hasta las próximas Cortes, se estableció la necesidad de consultar a la corte del Justicia antes de destinar cantidades extraordinarias para gastos imprevistos. Con el proceso de consulta, los diputados elevaban una petición a dicho tribunal para conseguir el permiso y destinar la cantidad necesitada para los más variados fines. Entre ellos, sufragar las impresiones a costa del reino, efectuar arreglos en el edificio de la Diputación, engalanar la sala de San Jorge, etc. Con los procesos de consulta, el Justiciazgo ejercía cierto control sobre una parte de los recursos económicos del reino administrados por la Diputación.

Este proceso de consulta consistía en la exposición por parte de los diputados de los motivos que tenían para llevar a cabo los gastos que surgían y poder afrontarlos con las rentas del reino. Toda la serie de procesos se guardaba en el armario 66 del archivo del reino. Los procesos de consulta deben ser cotejados con la serie de ápocas de salarios, comisiones y consultas, donde los diputados indicaban la necesidad de consultar con la corte del Justicia un asunto determinado. En estos registros se anotaban las cantidades pagadas mediante ápoca o recibo, correspondientes a cada proceso de consulta. Estos procesos se tramitaban en las escribanías de la corte del Justicia y eran los escribanos de dicha corte quienes debían remitirlos a los abogados, procuradores, etc.:

A causa de que las consultas y todos los procesos que a instancia de los señores diputados del Reyno penden en la Corte del Señor Justicia de Aragón, van por la escrivanía de Martín Juan de Lanuza, que tiene la letra D, y ofrécese entre año muchas vezes llevar estos procesos a casa de advogados y procuradores, por el travajo que en esto se ofrece a los escrivanos de la escrivanía, los señores diputados pusieron por cargo del arrendamiento se diesen a Martín Juan de Lanuza en cada un año doze escudos y diez sueldos y que con esto 
estubiese obligado de hazer llevar a sus escrivanos los procesos, siempre que fuese menester a las casas de los advogados y procuradores y adonde conviniesse. ${ }^{188}$

\section{Procesos de denunciación}

Serie de justicia. En el proceso de adquisición de una mayor representatividad política desarrollado por la Diputación, se asiste a un hecho de gran trascendencia en la vida administrativa y judicial de la relación entre las instituciones aragonesas. Desde 1436, el edificio de la Diputación alberga la sede de su consistorio, la corte del Justicia, las escribanías del zalmedina y, desde 1518, el tribunal de la Real Audiencia. Sin embargo, la tradicional independencia de la corte del Justicia, cuya actuación estaba únicamente vigilada por la potestad regia, se verá mermada al introducir los diputados del reino un procedimiento de vigilancia y control de la actividad procesal del Justicia de Aragón y sus lugartenientes. Por medio de dos oficios del reino, los inquisidores de procesos y los judicantes, se dota a todo el procedimiento de una articulación orgánica y funcional, cuyo resultado se verá trasladado documentalmente a los procesos generados en virtud de esta atribución: los procesos de denunciación (o procesos de «enquesta»).

Como indican Bonet, Sarasa y Redondo, «conseguirían crear el tribunal de los XVII judicantes, con el cual se alteraba el sistema procesal para exigir responsabilidades al Justicia de modo sustancial, dado que en lo anterior el tribunal competente eran las Cortes con el Rey [...] Su actuación se produciría a partir del momento en que recibieran el proceso preparado por los inquisidores elegidos al efecto. Las sentencias emitidas, previo asesoramiento, por este tribunal no tenían apelación ni podía legalmente impedirse su ejecución». ${ }^{189}$ En suma, se trata de articular un procedimiento que limite la autonomía del alto magistrado aragonés y sus lugartenientes. En 1467 se regula la actividad de unos inquisidores y unos judicantes encargados de desarrollar todo el procedimiento. Funcionarios que, recordémoslo, son oficios del reino, elegidos por el procedimiento de insaculación y, por tanto, sujetos a la disciplina interna dirigida por la Diputación y cuyos resultados documentales (procesos y actas de los inquisido-

188 Lorenzo Ibáñez de Aoiz, Ceremonial..., B.N.E., ms. 2922, f. 149v.

189 Ángel Bonet, Esteban Sarasa y Guillermo Redondo (1985), p. 21. 
res) quedarán en poder de los diputados en el archivo del reino y no del Justicia. Por tanto, no se puede hablar de documentación emanada de la corte del Justicia, ya que son oficios del reino los instructores y los resolutores, quedando estas tipologías bajo la jurisdicción de la Diputación y nunca del Justicia, aunque sean procesos que se instruyen contra sus oficiales.

Los inquisidores de procesos eran los encargados de recoger las quejas que particulares u órganos colegiados tenían contra cualquier miembro de la corte del Justicia, incluido él mismo. ${ }^{190} \mathrm{El}$ fuero de 1528 advertía sobre la necesidad de que todo aquel que iniciase un proceso de denunciación contra los oficiales debía mantenerlo hasta el final, procediendo contra el denunciante en caso de que la denunciación se hubiese presentado sin fundamento jurídico sólido. ${ }^{191}$ Además, en caso de que se abandonase, los diputados debían continuarlo hasta esclarecer las responsabilidades de los inculpados, según se desprendía del fuero de 1626. ${ }^{192}$

190 Lorenzo Ibáñez de Aoiz, Ceremonial..., B.U.Z., ms. 199, f. 39v: «Puédese dar denunciación contra los nombrados en el pregón, a saber es contra el señor Justicia de Aragón y los señores lugartenientes, notario y bergueros del señor Justicia de Aragón, conforme al fuero título Forus inquisitionis officii Justitie Aragonum, [...] y asimismo se puede dar denunciación contra los alguaciles, porteros y vergueros de la audiencia real».

191 Savall y Penén (1866), vol. 1, p. 156: «Item porque la facilidad de denunciar injusta $\&$ indebidamente $\&$ sin causa atemoriza a los Iuezes, por donde no se administra la Iusticia tan liberamente como devría. Porende, estatuymos y ordenamos que si el denunciante acusara o denunciara frívola, injusta o calumniosamente, que si el tal denunciante sucumbirá la causa, o el dicho denunciado será absuelto de las cosas contenidas en la denunciación, sea condemnado en los daños y expensas dobladas. Excepto si el denunciante fuere el procurador del Reyno, haviendo tenido justa causa de acusar; para las quales, al tiempo que diere la denunciación sea tenido \& obligado dar ante los inquisidores en el processo de la dicha denunciación caución fidejussoria, idónea y suficiente. Las quales expensas y daños hayan de ser executados en los bienes del denunciante, e sus fianças y de cada uno dellos privilegiadamente, según que ya por fuero en las expensas de las dichas denunciaciones está dispuesto y ordenado».

192 Savall y Penén (1866), vol. 1, p. 446: «Que los Diputados no se puedan apartar de las denunciaciones. Otrosí su Magestad, y en su Real nombre el Excelentísimo Conde de Monterrey, de voluntad de la Corte y quatro Braços de aquella, estatuye y ordena, que de la manera que los diputados del Reyno tienen obligación de seguir las denunciaciones de los lugartenientes de la Corte del Iusticia de Aragón, en caso que el que las diere se apartare dellas, que de la misma manera, tengan obligación los diputados de seguir las denunciaciones dadas por ellos o sus antecessores, y no se puedan apartar de las ya dadas, assí por sus predecessores como por ellos, antes bien hayan de seguir aquellas a expensas y costas del Reyno, sin que sea necessario consulta de la Corte del Iusticia de Aragón, ni consentimiento del advogado fiscal, siendo bastante póliza o cédula firmada por cinco Diputados, o de la mayor parte de los que asistieren en el tribunal el día que se firmare. Pero, que se entienda en las tres mil o cinco mil libras, que sin consentimiento del advogado fiscal pueden gastar». 
Estos inquisidores actuaban como incoadores del proceso de denunciación y los diputados actúan en el procedimiento judicial como parte implicada, al considerar que se ha vulnerado el ordenamiento jurídico por parte de un oficial del Justicia, a quien se denuncia por parte de particulares, instituciones, etc. ${ }^{193}$

Los inquisidores se reunían en la sala de San Jorge y tenían la jurisdicción para tramitar todo el procedimiento, admitir testigos y pruebas documentales, etc.; en suma, instruir la causa: «y en casso se den denunciaciones dentro del tiempo arriva referido, el proceso de aquellas se actita ante los inquisidores en la forma que dispone el fuero título Forus Inquisicionis officii Justitie Aragonum, fol. 76». ${ }^{194}$ En esta fase de instrucción sólo se admiten testimonios que tengan que ver directamente con el asunto denunciado y, además, sólo se admiten cuatro testigos. ${ }^{195}$ En términos generales, la fase de instrucción comprende una presentación del caso, la

193 A.G.S., Secretaría y Superintendencia de Hacienda, leg. 539: «Y para obligarles al más puntual cumplimiento de su obligación, se concedía poder y facultad en los mismos fueros a qualquier persona, colegio o universidad de este Reyno (excepto del Real Fisco) que pretendiese hallarse agraviada por alguno de los lugarthenientes, notarios y bergueros del Justicia de Aragón de dar ante las diez y siete personas legas, que a este fin devían sortearse annualmente el día primero de abril de la bolsa llamada de ynquisidores de procesos, las que en el término de quarenta días con dictamen de los adbogados, que en caso necesario podían eligir, devían determinar y sentenciar dichas causas de denunciaciones y si resultase que el Justicia de Aragón o sus lugarthenientes huviesen delinquido, con dolo, o soborno, que en tal caso se le devía ymponer la pena de privación de qualquier oficio que tuviere o pudiere tener así del Rey de su lugartheniente, como de qualquiera ciudad, villa o lugar de este Reyno los daños doblados y los daños de la parte lesa; y si resultase que el denunciador huviere procedido con calumnia, y fuere absuelto el denunciado, devía condenarse a aquel en todas las costas que se huvieren costado; sin que la parte denunciante pudiera separarse, convenirse, ni renunciar la denunciación si de algún modo constase en el proceso del delito que se imputava; porque en este caso, tenía obligación de seguir la causa el procurador del Reyno».

194 Lorenzo Ibáñez de Aoiz, Ceremonial..., B.U.Z., ms. 199, f. 40v.

195 Savall y Penén (1866), vol. 1, pp. 480-481: «De los días en que se dan las denunciaciones y forma de proceder en ellas: Por quanto por fuero está dispuesto que las denunciaciones se hayan de dar a los lugartenientes de la Cort del Iusticia de Aragón y otros oficiales sugetos a la enquesta de los iudicantes, dentro de los primeros diez días del mes de abril [...] Otrosí, para que con más facilidad y menos gasto se hagan los procesos de denunciaciones, su Magestad de voluntad de la Corte y quatro Braços della estatuye y ordena que de aquí adelante no se admitan en dichos procesos de denunciaciones artículos, sino los que directamente pertenecen a la causa, cuyo conocimiento sea de los inquisidores de los dichos processos, pronunciado verbalmente dicho incidente y que sobre los artículos de abonatorio o calificación del denunciado no se puedan recibir sino quatro testigos y no más». 
aportación del testimonio directamente por el interesado o su procurador, así como la solicitud elevada a los inquisidores de procesos para que se ocupen del caso. A continuación se cita a los testigos para que también aporten su testimonio y finalmente se procede a su recepción.

Sin embargo, la sentencia final del proceso compete a los judicantes, que en número de diecisiete componen el tribunal de resolución judicial. De hecho, una vez incoado el proceso, toda la documentación es remitida al tribunal de los diecisiete judicantes para que dicten sentencia definitiva e inapelable: "y los inquisidores entregan el proceso o procesos que ante ellos se an actitado a los judicantes, con ápoca, exceptado que si la denunciación es contra el señor Justicia de Aragón el conocimiento no es de los judicantes, sino que se aguarda a las primeras cortes, en las quales su Magestad y los quatro braços an de conocer de su causa». ${ }^{196}$

En todo el procedimiento, podía suceder que los notarios sustitutos del notario principal del proceso de encuesta no entregasen al notario principal los procesos, y las partes quedaban sin saber dónde estaban éstos. En 1646 se manda que el notario sustituto se obligue a entregar al principal los procesos una vez concluidos. Además, el notario principal de una escribanía debe, antes de incorporarse a su ejercicio, recibir un inventario de todos los procesos que esa escribanía está siguiendo, como medio eficaz de control documental y administrativo de los procesos y negocios en curso. ${ }^{197}$

196 Lorenzo Ibáñez de Aoiz, Ceremonial..., B.U.Z., ms. 199, f. 40v.

197 Savall y Penén (1866), Fueros, observancias..., vol. 1, p. 489: «De los processos de la enquesta. Por quanto los notarios substitutos del principal de la Enquesta y otros que actitan processos della con comisarios, muchas vezes no los entregan a dicho escrivano principal y las partes no tienen noticia dónde están, de que se sigue mucho daño. Por tanto, su Magestad, de voluntad de la Corte y quatro Braços della, estatuye y ordena, que sólo por el escrivano y notario principal nombrado por su Magestad o sus substitutos, puedan actitarse los processos de la enquesta; y dichos substitutos y el otro dellos, concluidos dichos processos o siempre que dicho notario principal se los pidiere, los hayan de entregar y de los que actitaren fuera de la ciudad de Zaragoça, tenga obligación de entregar ápoca, para que conste de los processos que han entrado en poder de aquél y dellos, tenga obligación de dar quenta. Otrosí, su Magestad, de voluntad de la Corte y quatro braços della, estatuye y ordena que el escrivano y notario principal de dicha escrivanía nombrado por su Magestad, luego que huviere jurado dicho oficio, antes de exercer aquél, tenga obligación de recibir por inventario los processos que en dicha escrivanía huviere, para que constando de los que han entrado en su poder, dé cuenta dellos a las partes y para que conste de dicho inventario y de los processos que havrá recibido de los notarios que los havrán actitado, el iuez de enquesta tenga obligación de tener un libro donde dichos inventarios y ápocas se escrivan y asienten, el qual successivamente esté en poder del iuez proveído». 
Son, por tanto, los diecisiete judicantes los que resuelven el proceso de denunciación, manteniendo la siguiente tramitación administrativa: una vez entregada la documentación de instrucción con ápoca de recibo, los judicantes se despiden de los inquisidores, se sientan en la sala real y comienzan a ejercer sus oficios. Los judicantes tienen de tiempo para oír a las partes hasta el día 20 de julio de cada año. Aunque no son letrados, disponen de un importante asesoramiento jurídico y administrativo, representado por dos letrados y asesores y el notario de judicantes. ${ }^{198}$ Una vez dictada sentencia condenatoria o absolutoria, el portero y notario de dichos judicantes intiman o informan al acusado del resultado. Sin embargo, el fuero de Monzón de 1585 «De la execución de costas de sentencia dada por los diez y siete iudicantes» venía a paliar la práctica perniciosa de algunos judicantes, que una vez dictada sentencia se desentendían del cobro de las costas del proceso y de la ejecución directa de la sentencia, con la consiguiente cobranza pecuniaria. A tal efecto, se ordenaba que «qualquiere de los dichos diez y siete iudicantes que se hallaren en la ciudad de Çaragoça requerido por la parte, sea obligado mandar executar y vender los bienes del condemnado, y de sus fianças, en dichos daños y costas, sumariamente sin guardar solemnidad alguna, so pena de perder el tal iudicante la metad del salario de su oficio». ${ }^{199}$

Finalmente, el proceso actuado y definitivamente tramitado lo remiten los notarios sustitutos del notario responsable a éste. ${ }^{200}$ Posteriormente es enviado al archivo del reino, donde se custodiará con el resto de procesos de denunciación en los armarios 72, 73, 80, 81, 87 y 88: «Hecho esto, los

198 Los inquisidores contratan en julio de 1636 a juristas para que les aconsejen en los procesos de denunciación: Registro de actos comunes del año 1636, A.D.P.Z., ms. 424, f. 46v-47v: «Inquisidores extractos y nombrados conforme a fuero para hazer y fulminar los procesos de denunciaciones del Justicia de Aragón, sus lugartenientes y demás oficiales y personas que conforme a fuero pueden ser inquiridas para este presente año mil seyscientos treynta y seys, a los illustrísimos señores diputados del presente Reyno de Aragón, salud y augmento de estado. Hacemos saber a vuestras señorías illustrísimas de que en las causas de denunciaciones que han pendido en este nuestro tribunal por haverse en ellas offrecido muchas y arduas dificultades, las quales sin consejo y parezer de personas peritas y pláticas en fuero y derecho no podían aquellas declarar, para ello hicimos electión de los doctores Juan Francisco Romeu y Jusephe Porter, para que nos aconsejassen lo que devíamos de hacer y procediese justicia en dichas causas. Los quales, con orden y mandamiento nuestro, han asistido en el dicho nuestro tribunal a saber [...]».

199 Savall y Penén (1866), vol. 1, p. 418.

200 Savall y Penén (1866), vol. 1, p. 489. 
dichos judicantes entregan el proceso a los señores diputados, los quales lo ponen en el archiu mediante acto que testifica su notario extracto».201

Procesos (civiles) de fraudes, ejecuciones y ocupaciones

Serie de justicia. Las acciones delictivas realizadas contra el sistema de recolección del impuesto de las generalidades eran competencia de los diputados. Generalmente era el arrendador quien resolvía el conflicto, ocasionado tanto por comerciantes que no declaraban las mercancías como por encargados de la colecta directa que se demoraban en la entrega de las cantidades recaudadas. Sin embargo, cuando el arrendador se veía incapaz para restablecer la situación, la Diputación ejercía toda su autoridad y jurisdicción. Daños, robos, ocupaciones ilegales y contrabando de las mercancías sujetas al pago del impuesto se tipificaban como delitos y fraudes que atentaban directamente sobre la principal fuente de ingresos de la hacienda aragonesa y, por tanto, responsabilidad absoluta de los diputados. Los procesos por fraudes contra las generalidades se dividían entre pleitos civiles o seguidos por la vía ordinaria y procesos ejecutivos sobre ocupación de personas y bienes para resarcir la justicia ejecutiva de los diputados en materia de generalidades. ${ }^{202}$

Las ordinaciones de 1519 lo establecían así. De hecho, se otorgaba poder y jurisdicción civil sobre todos los arrendadores, cogedores y funcionarios subalternos que participaran en el sistema fiscal «e succesores dellos e de qualquiere dellos e sobre todas e qualesquiere personas e universidades que farán o havrán hecho frau o denegación de paga, resistencia o empacho alguno a la collecta del dicho general et de los dichos drechos». 203

Por lo general, los delitos contra el impuesto de generalidades se iniciaban con una denuncia del arrendador o alguno de sus colaboradores. Se citaba al acusado para que presentase su defensa dentro de un plazo de 15

201 Lorenzo Ibáñez de Aoiz, Ceremonial..., B.U.Z., ms. 199, f. 57v.

202 Gregorio Colás y José Antonio Salas (1977), p. 21: «los encargados de vigilar el cumplimiento de la normativa que regía el comercio, el pago de las tasas aduaneras, las viedas y demás funciones de la Diputación se conocían con el nombre de "guardas". Las infracciones se denominaban "fraus" y las penas solían consistir en la confiscación de los productos cogidos en "frao" y una pena pecuniaria".

203 Savall y Penén (1866), vol. 2, pp. 320 y ss. 
a 20 días. Tras este período, era juzgado como contumaz y se dictaba sentencia únicamente con las pruebas de la acusación. En caso de que el acusado presente pruebas a su favor, los diputados juzgan el caso y dictan sentencia. Ésta suele consistir en el pago de las cantidades estipuladas mediante un acuerdo entre el defraudador y el arrendador. En caso de que el primero no cumpla con la sentencia, los diputados ponen en marcha sus órganos subalternos (porteros fundamentalmente) y proceden a embargar los bienes para su venta y la satisfacción de los gastos.

Caso diferente es el que implica a los propios recolectores de las cantidades derivadas del impuesto. Collidores, sobrecollidores y guardas son acusados de fraude contra el general en caso de que cometan los siguientes delitos: la no anotación en el libro de la tabla de los albaranes cobrados, la no liquidación total de la cuenta o el acuerdo establecido con mercaderes fraudulentos y contrabandistas "para permitir el paso sin abonar el derecho». ${ }^{204}$

Los fueros de 1687 establecen el modo de proceder en las causas por mazarrón o contrabando de mercancías, para las que se debe «hazer processo sumario en escrito con los términos que al Consistorio de los Diputados pareciere señalar, assí a la parte del delator, como a la del delatado, y comunicando las probanças de la una parte a la otra, pero sin poner en el processo, ni comunicar los nombres, ni sobrenombres de los delatores, ni testigos, reservándose para sí los diputados dichos nombres». ${ }^{205}$ Estos procesos constan de una actuación de naturaleza denunciatoria, seguida de las pruebas testificales y documentales y del testimonio de las partes implicadas y testigos. Una vez reunida la información necesaria que conforma el proceso, los diputados proceden a dictar sentencia, generalmente de naturaleza ejecutiva y pecuniaria, de tal modo que se pasase a la vía ejecutiva de las cantidades defraudadas por medio de los porteros de los diputados, que se encargaban de ocupar los bienes del denunciado hasta resarcir el fraude. Con respecto a esta sentencia, los fueros estipulan muy claramente que «las sentencias de los señores diputados en las causas de la Generalidad, tiene execución privilegiada y no ay recurso de ellas».

204 José Ángel Sesma (1977), p. 255.

205 Savall y Penén (1866), vol. 1, pp. 535 y ss. 


\section{Procesos de habilitación de infanzonía}

Serie de justicia. La jurisdicción de los diputados en todo lo referido al nombramiento y elección de los oficios del reino incluía una serie de actuaciones jurídicas previas de garantía. Entre ellas figuraba la comprobación y autenticación de que los candidatos a ser insaculados gozaban de la categoría necesaria (nobles, infanzones, prelados) como integrantes de cada uno de los brazos, aunque este poder también lo podían ejercer la Real Audiencia y la corte del Justicia: «Está tan ceñido el poder y jurisdición de los Señores Diputados a lo expressado en los Fueros y Actos de Corte, que tocándoles el insacular en los oficios de la Diputación y conocer si los insaculados tienen o no las calidades según los Actos de Corte [...] por no averse dado a los Señores Diputados privativamente este conocimiento, lo tienen también la Real Audiencia y Corte». ${ }^{206}$

Los procesos de habilitación de infanzonía tienen por objeto probar esta calidad ante los diputados para que posteriormente el interesado pueda ser insaculado en los oficios del reino, cuyo proceso de nombramiento (elaboración de matrículas de insaculados, ceremonia de extracción en la sala real, etc.) es controlado totalmente por los diputados. ${ }^{207}$ Esta serie documental está directamente relacionada con los procesos de insaculación donde los interesados expresaban su disconformidad con el resultado de la insaculación o elección de los oficios del reino, formando ambos procesos el control del procedimiento de elección de nuevos cargos. El interés de esta serie estriba en que incluía copia del proceso de infanzonía (insertado en el proceso de habilitación) actuado ante la Audiencia Real. Pero procesos de infanzonía (tramitados ante la Audiencia) y procesos de habilitación de infanzonía (tramitados ante los diputados del reino) son tipologías diferentes. ${ }^{208}$

206 B.N.E., ms. 8380, f. 263. Incluye el impreso titulado Del oficio, poder y jurisdición de los ilustrísimos señores diputados del Reyno de Aragón.

207 Vid. el análisis de un proceso de infanzonía seguido ante los diputados del reino en Alberto Montaner y Diego Navarro (1995).

208 Javier Cañada Sauras (1978a) y (1978b). Benito Vicente de Cuéllar (1988), p. 29: «Al principio, el órgano jurisdiccional competente para entender de los procesos de infanzonía era el Rey, personificación del poder del Estado, o la persona en quien él delegase. Posteriormente, esta función se atribuyó a los máximos órganos jurisdiccionales del Reino, la Audiencia Real y la Corte del Justicia. Finalmente, fue competencia de la Real Audiencia». 
Estos procesos se reducían a justificar formalmente los individuos del reino de Aragón de quienes no constaba (o se ponía en duda) que se hallaban con las calidades prevenidas por fuero para insacularse en las bolsas de diputados y demás oficios del reino, a fin de que se pudiesen incluir en ellas. Ocupaban los armarios 50 y 55 y se había elaborado un modo de recuperación de dichos procesos. La clave para su identificación se especifica en las «Instrucciones para buscar papeles del nobiliario de Aragón del Archivo de la Diputación»: "Quando dice en el registro de varias infanzonías y privilegios del archivo de la Diputación, se mirará en su Archivo, en el legajo con este título y el del Almario 55, que dice: procesos de havilitaciones; quando diga en el proceso de havilitaciones, se mirará en el año respectivo que cite en qualquiera de los 3 almarios 47, 50 y 55». ${ }^{209}$

El proceso constaba de varias partes. En primer lugar, los diputados reunidos en consistorio recibían al procurador del interesado, quien les debía mostrar que su promocionado tenía las calidades nobiliarias previstas por fuero. Para ello exhibía generalmente una firma casual de infanzonía y otros documentos que atestiguasen mediante testimonios fehacientes dicha calidad. En el proceso, como se ha indicado, se incluía la salva de infanzonía proveída por la corte del Justicia.

\section{Procesos de insaculación}

Serie de justicia. Como hemos dicho con relación a los procesos de habilitación de infanzonía, los diputados velaban por la legalidad de todo el procedimiento de insaculación. Previo al proceso, los diputados obligaban a probar las calidades nobiliarias de los posibles candidatos a participar en la insaculación para los oficios del reino. No obstante, una vez celebrada la insaculación, sus resultados no siempre eran del agrado y satisfacción de todos los interesados, apelando generalmente a la falta de calidad nobiliaria del insaculado. Solamente podían habilitarse para sortear los oficios de diputados, y otros que constituían la voz del reino, aquellas personas que se hallaban con las calidades prevenidas por fuero; sobre si las tenían para entrar en bolsa o si les faltaban a algunos de los que ya se hallaban insaculados se suscitaban estas dudas y pleitos, que se seguían y substanciaban en

209 Instrucciones para buscar papeles del nobiliario de Aragón del archivo de la Diputación, A.D.P.Z., leg. 755-23. 
el tribunal de las diputaciones mediante procesos formales. Por ello se abría una segunda vía de control, a posteriori, que intentaba hacer justicia sobre las irregularidades que a juicio de los interesados se habían cometido en la extracción, dando lugar a los procesos por insaculación.

\section{Procesos de sumarias informaciones}

Serie de justicia. Constituyen un recurso de información necesaria al servicio de los diputados para perseguir los fraudes y delitos cometidos en contra de las generalidades del reino. Constaban de las relaciones que los comisarios nombrados por los diputados enviaban a éstos informando de personas, acciones y situaciones constitutivas de delito. Sin embargo, también son realizados en el ejercicio de la acumulación de datos e informaciones recopiladas para dar prueba de una situación, privilegio, delito o cualquier otra circunstancia que de una manera u otra afectase a los intereses de los diputados del reino. A pesar de que son escasos los testimonios originales conservados hasta nuestros días, la serie de procesos de sumarias informaciones ocupaba completamente el armario n. ${ }^{\circ} 71$ del archivo del reino. $^{210}$

\section{Procesos de suplicaciones}

Serie de justicia. Dentro de la denominada justicia distributiva, los diputados del reino atendían las solicitudes, generalmente pecuniarias, que particulares, concejos y otras instituciones elevaban ante dicho consistorio. Como indican Colás y Salas, "otra de las misiones de la Diputación era la ayuda monetaria a las universidades cuando, por las causas que fueran, sus necesidades eran particularmente graves». ${ }^{211}$ Con el asesoramiento jurídico de los abogados del reino, los diputados recibían peticiones de natura-

210 En R.A.H., ms. 9/548, f. 25-59, se encuentra copia auténtica del proceso de sumaria información sobre la limpieza de sangre de Margarita Malo, mujer del cronista Blancas. Este proceso no es sino la probanza de la limpieza de linaje para ser admitida en la cofradía de Santa María la Mayor de Zaragoza. En él desfilan testigos que aportan su testimonio para declarar la cristiandad de la solicitante. Por ello, más que proceso en sentido estricto constituye un a modo de expediente de limpieza de sangre. Sin embargo, habida cuenta de las materias indicadas en el armario 71 , los procesos de sumarias informaciones se tramitaban ante muy diversas causas como tipo documental necesario para recopilar información y dictar una sentencia.

211 Gregorio Colás y José Antonio Salas (1977), p. 20. 
leza generalmente económica. Arreglos de puentes y redes viarias, ayudas para la impresión de obras jurídicas o históricas, eran algunas de las materias incluidas en dichos procesos.

Una vez recibida la súplica, que incoaba el proceso, los diputados consultaban con sus abogados y después con la corte del Justicia para determinar el permiso o su denegación para acceder a la extensión de dicha ayuda económica.

Procesos de vedas de panes y carnes

Serie de justicia. Una de las funciones de los diputados consiste en asegurar el abastecimiento de los productos básicos a todos los regnícolas. Desde 1585 se había prohibido la extracción de carne o pan a otros lugares fuera del reino sin permiso expreso de los diputados. Los infractores de esta medida eran acusados ante los diputados, quienes tramitaban los procesos por vedas de panes y carnes. ${ }^{212}$ En primer lugar, los diputados hacían saber mediante pregones la prohibición. Luego nombraban comisarios para velar por su cumplimiento y ocupar las mercancías de todo aquel que hubiese contravenido la norma dictada por ellos: «la importación y exportación de cereales dependían de los permisos de los diputados. De la junta o "consistorio" de éstos salían las órdenes de prohibir la saca de panes en los años de malas cosechas. Por todo el Reino hacían pregones vedando la exportación de trigo, ordio y todo tipo de cereales. Estos pregones recibían el nombre de «viedas» y tenían vigencia hasta que no eran expresamente revocados mediante otra disposición». ${ }^{213}$

\section{Registros de actos comunes}

Serie de gobierno. Disposiciones emanadas. La escrituración de los actos jurídicos efectuados en presencia del equipo de gobierno de la Diputación y su personal de apoyo administrativo se refleja en las actas del consistorio aragonés, representadas por los registros de actos comunes. La sistematización de esta tipología documental se debe entender en un proceso más amplio que afecta por igual a cuantas instituciones, concejos, cofradías, etc. decidan poner por escrito y en un orden determinado todos

212 Savall y Penén (1866), vol. 1, p. 416.

213 Gregorio Colás y José Antonio Salas (1977), p. 21. 
los acuerdos tomados en el ejercicio de las competencias asignadas. Antonio Castillo indica con respecto a los libros de actas que se trata de uno de los más conseguidos ejemplos de las "prácticas del escribir administrativo»:

La ejecución de este tipo de libros y su modo de producción son el reflejo de una actividad de escritura organizada en términos racionales. Normalmente se articula como una secuencia cronológica de los asientos correspondientes a los distintos acuerdos, visualmente diferenciables por el uso de signos que marcan el comienzo de cada párrafo, un mayor espacio interlineal entre el final de un acuerdo y el comienzo de otro, y, fundamentalmente, la anotación en el margen derecho del asunto tratado. ${ }^{214}$

En efecto, los registros de actos comunes de la Diputación del reino de Aragón son la serie documental que permite hilvanar cronológicamente la actuación de la institución en los ámbitos de su competencia. En estos registros se escrituraban las providencias, resoluciones, cancelaciones de censales, arrendamientos de las generalidades, instrucciones, embajadas, cartas, etc., conformando un libro registro fedatario de los actos generados por los diputados y que constituía, en última instancia, la seguridad de los derechos del reino. Los acuerdos reflejados en estos registros se tomaban por los diputados reunidos en consistorio. La eficacia jurídica de dichos actos dependía de la presencia del notario extracto o sustituto de la Diputación para garantizar la autenticidad jurídica del acto escriturado. Cada año, los registros de actos comunes copiados de los bastardelos de los notarios en las escribanías de la Diputación se entregaban al secretario y éste los depositaba en el archivo del reino mediante una relación de entrega:

[26 de junio de 1600]

Sea a todos manifiesto que yo, Pedro López, infançón, domiciliado en la ciudad de Çaragoça, escrivano principal de la Dipputación del presente Reyno de Aragón y secretario de aquella en el dicho nombre, de mi cierta sciencia otorgo haver recevido de Domingo Azeylla, notario extracto de la Dipputación que ha sido en el año próxime pasado de 1599 y de Miguel Arcentín, y Antonio Latassa, notarios sustitutos de dicha dipputación y de dicho Domingo Azaylla, notario extracto sobredicho y por manos del dicho Miguel Arcentín, los registros, procesos, escripturas y actos infraescriptos y siguientes, a saber: el registro de los actos comunes de dicha dipputación $[\ldots] .^{215}$

214 Antonio Castillo (1997), p. 218.

215 Registro de actos comunes de 1599, A.D.P.Z., ms. 286, f. 289 r. 
Por otra parte, la inserción de documentos originales entre sus folios como apoyo documental a los actos documentados en el registro convierte a éste en una especie de "libro-archivo" donde se adjuntan escrituras relacionadas con los asuntos tratados. ${ }^{216}$ Junto a estas características, se debe mencionar la inclusión casi generalizada de un índice o «tabla de las materias más destacadas tratadas en el registro", que supone el triunfo de los procedimientos de indización y resumen como medio de acceso rápido y eficaz a la información documentada en cada registro. No obstante, este acceso alfabético consistía en una lista en la que se mezclaban indistintamente las tipologías documentales (ápocas, procuras, etc.) con las acciones (aperciones, comisiones, ejecuciones, etc.).

\section{Registros de ápocas de pensiones de censales}

Serie de hacienda. Ingresos extraordinarios. Dentro de los ingresos extraordinarios percibidos por el reino y gestionados por la Diputación se encuentra la emisión de los censales o deuda pública a un interés variable. En un censal hay que distinguir entre los conceptos de propiedad y de rentabilidad emanada de dicho censal. Las variaciones de propiedad se anotan en los cabreos de censales. No obstante, las cantidades pagadas por los intereses emanados de dichos censales se anotan en los registros de ápocas (recibos) de pensiones de censales. En definitiva, en estos registros se anotaban las cantidades recibidas por los inversores, mediante albarán o recibo, en los que otorgaban haber cobrado el interés estipulado, mientras que en los libros de cuentas del general aparecían las mismas cantidades extendidas por el administrador en virtud de las cautelas u órdenes de pago extendidas por los diputados y recogidas en los registros de actos comunes.

En un primer momento, las ápocas o recibos de las pensiones de los censales, los pagos en concepto de salarios y las comisiones y consultas quedaron registrados en un mismo tipo documental que agrupaba todas estas partidas. Sin embargo, a partir de 1602 se distinguen dos registros: los de ápocas de censales, por una parte, y los de ápocas de salarios, comisiones y consultas, por otra. Todo el control de los gastos relativos a estos conceptos queda bajo la supervisión de los inquisidores de cuentas auxiliados por su personal administrativo y fedatario: 
Todo esto comprehende la jurisdición de los Señores Inquisidores de cuentas, examinando si se han empleado los censos y tributos del Reyno, que son los drechos de la Generalidad, en la paga de los salarios de los oficios de la Diputación y de la administración de la justicia y otros cargos y de las pensiones y luición de censales, dentro de las facultades dadas por los fueros y actos de corte y según ellas y no de otra manera y en caso de aver excedido los señores diputados o el administrador o arrendador de la Generalidad de las dichas facultades, encautan que se recobre lo que se huviere pagado contra tenor de los Fueros y Actos de Corte, en algunos casos hazen executar las penas en que se les ha dado conocimiento, poder y autoridad. ${ }^{217}$

\section{Registros de ápocas de salarios, comisiones y consultas}

Serie de hacienda. Generalidades. Mediante estos registros, fundamentales para la correcta marcha económica del presupuesto de la Diputación, el secretario tenía constancia, mediante las ápocas o recibos, de las cantidades gastadas en todos los salarios de los cargos ordinarios y extraordinarios de los diputados, del dinero invertido en numerosos asuntos debatidos ante la corte del Justicia mediante la preceptiva consulta y de las diferentes comisiones encomendadas a personas para realizar acciones de muy diverso signo por mandato de los diputados. Como la mayoría de los registros contables de la Diputación, cada entrada del registro hacía referencia a la cantidad de dinero abonada regularmente en cada ejercicio. Se hacía constar el cargo, el nombre del interesado y la cantidad abonada. Por otra parte, los gastos sufragados mediante consulta interpuesta solían ir acompañados de la propia consulta elevada ante la corte del Justicia, que debía aceptar y autorizar dicho desembolso extraordinario.

\section{Registros de ápocas del servicio de la sisa}

Serie de hacienda. Sisa. Libro registro donde se anotaban los actos derivados de la gestión del impuesto de la sisa. ${ }^{218}$ Consistía en «una disminu-

217 B.N.E., ms. 8380, f. 263. Incluye el impreso titulado Del oficio, poder y jurisdición de los ilustrísimos señores diputados del Reyno de Aragón. Vid. además Savall y Penén (1866), vol. 1, p. 519: «De los inquisidores de cuentas».

218 Registro de actos comunes de 1496, A.D.P.Z., ms. 85, f. 49r-49v, 20 de mayo de 1497: «Por quanto en el conto por vos dado en el mes de abril más cerqua pasado que es el segundo anyo de la present arrendación havemos tachado a Jayme Malo, notario de la cort por los albaranes de las sissas y otros actos tres mil sueldos jaqueses, los quales por la brevedat del tiempo no pudimos assí haver información de los treballos por él sustenidos, assí en los albaranes como en el libro de la investigación de las dichas sissas, como en los actos de los ministros de la gente de armas, cautelas e ápocas de los capitanes». 
ción o merma en el peso o medida de determinados productos de consumo, principalmente pan, carne, vino, pescado, etc., cuyo importe entregaban los vendedores al Fisco». ${ }^{219} \mathrm{El}$ importe de lo obtenido por este procedimiento iba a parar a la concesión de la ayuda económica al monarca, cuyo monto total iba generalmente destinado al sufragio de las campañas militares. El encargado de realizar la recogida es el collidor, que entrega las cantidades recaudadas al recaudador general del reino. Sin embargo, como indica Sesma,

Aun cuando el cobro de las sisas no supone un ingreso para el General, la Diputación, como organismo estable que representa al reino, con jurisdicción en la totalidad del territorio aragonés y con organización y experiencia en asuntos de administración y cobro de impuestos, es la encargada de velar por una justa y eficaz recaudación de las sisas. Su actuación va dirigida a aplicar y hacer observar los actos de las Cortes, solventando las diferencias entre los interesados y procurando que todos abonen lo que están obligados. Se constituye en juez de los problemas suscitados entre los oficios de las universidades y los contribuyentes y entre los distintos lugares que tienen diferencias de cualquier tipo. ${ }^{220}$

\section{Registros de cartas (misivas y responsivas)}

Serie de gobierno. Comunicación. La acción de gobierno requiere de instrumentos que permitan tender una relación estrecha y eficaz entre la sede institucional y el resto de administraciones y administrados. ${ }^{221}$ En definitiva, se trata, al igual que en el resto de los Estados modernos, de disponer de la información y los instrumentos para su gestión y aprovechamiento necesarios para ejercer las funciones tanto en el interior como en el exterior de los territorios y vencer así la distancia física. ${ }^{222}$ Estas relaciones, así como la disposición de información de hechos ocurridos fuera de las estrechas fronteras zaragozanas, se rigen por tipologías documentales que permiten, a un mismo tiempo, disponer de información inmediata y

219 José Ángel Sesma (1977), p. 139.

220 José Ángel Sesma (1977), p. 145.

221 José L. Gotor (1988). Francisco M. Gimeno Blay (1999), p. 194: «los diversos empleos de la cultura escrita contribuyeron de manera decisiva a la conformación del complejo tejido organizativo del nuevo estado, proporcionándole la posibilidad de gobernar desde la ausencia y transmitir las órdenes a tierras lejanas». María Águeda Moreno Moreno (2000).

222 Manuel Fernández Álvarez (1989), p. 689. Fernand Braudel (1987), vol. 1, pp. 474 y especialmente 484-486: «Las cartas: un caso especial». 
frecuente y mantener los necesarios lazos institucionales entre diversas instancias de poder. La correspondencia emanada y recibida por la Diputación del reino en el ejercicio de sus competencias constituye uno de los principales apoyos documentales a la tarea de gobierno y al conocimiento de la realidad interna y externa del reino aragonés.

Los registros de cartas misivas y responsivas incluyen indistintamente las copias de las enviadas por los diputados y las originales recibidas por éstos. Sobre estos registros y su contenido, los trabajos de San Vicente y Crosby ilustran la importancia de las cartas de la Diputación. ${ }^{223}$ Éstas permiten conocer y seguir con detalle los muy variados asuntos tramitados por los diputados, quienes reciben información de sus agentes desplazados a Madrid y Roma, de otras instituciones, concejos, ministros de la Monarquía, etc., apoyando la tarea de gobierno y reuniendo en poder de los diputados un acervo informativo y documental de gran valor en su momento para el despacho de los asuntos y de importancia capital para la construcción histórica hoy en día.

\section{Registros de Cortes}

Serie de gobierno. Disposiciones recibidas. Los registros de las sesiones de Cortes del reino de Aragón constituyen una de las muestras documentales más sólidas para argumentar la conservación de la memoria histórica aragonesa. La transcripción de los parlamentos entre los brazos registra las deliberaciones entre la representación del reino y el monarca. ${ }^{224}$ La importancia de esta tipología motivó que desde el comienzo de la andadura histórica del archivo del reino quedase estipulado que fueran los diputados quienes custodiasen los registros de Cortes en el archivo del reino. Esteban Sarasa, uno de los mejores conocedores de esta tipología documental, describe sus características formales:

Las «actas de los procesos de Cortes» han llegado hasta nuestros días en códices en papel tamaño mayor, que son el resultado del traslado oficial de las anotaciones hechas en el momento por los notarios y escribanos destinados a recoger puntualmente los pormenores de las asambleas. Del original se solían

223 Ángel San Vicente Pino y J. O. Crosby (1963) y (1968-1969).

224 Ver en general Esteban Sarasa y Ángel Sesma (1976). F. Udina Martorell (1982). Esteban Sarasa (1988) y (1989). Con respecto a los procesos de Cortes del reinado de Fernando II e Isabel la Católica, ver Ricardo del Arco y Garay (1954). 
hacer tres copias: una para el archivo de la Corona, desde el siglo XIV; otra para el Archivo del Reino y una tercera para la corte del Justicia de Aragón, o después, para los diputados de la Diputación General; de ahí que en muchos casos se hayan conservado hasta dos manuscritos de un proceso, con escasas variantes, y, en ocasiones, hasta tres. Todo ello sin contar con la documentación derivada de las actuaciones en Cortes que tiene una mayor dispersión y diversidad. ${ }^{225}$

Por su parte, Hernández Calleja ha analizado los procesos de Cortes desde un punto de vista documental, indicando que

El proceso de cortes se podría definir como la unidad documental que reúne el conjunto de actuaciones que se producen en la Corte durante su celebración. Es un registro de las sesiones en el que se insertan literalmente los documentos a los que se hace alusión. La puesta por escrito de lo que acontecía era un formalismo más de los que la caracterizan como institución. Las discusiones de los brazos, de los tractadors, de las diversas comisiones..., se plasmaban en documentos que luego se leían donde procedía. El rey también solía comunicarse por escrito por medio del protonotario. En líneas generales, se puede decir que en el proceso de cortes se registran, cronológicamente insertados, los siguientes tipos de documentos: los que aportan las partes: rey-brazos; los que aportan eventuales intervinientes: personajes externos a la corte como por ejemplo embajadores extranjeros; los que emanan de la corte como institución: órdenes a los diputados del General, cautelas, etc. Conviene recordar que toda esta documentación que aparece registrada en el proceso existía físicamente en forma de documentos originales o en borrador. En resumen, el proceso es el acta diaria de lo que ocurre, que incluye la documentación que se produce, expide y recibe. No quiere ello decir que haya quedado plasmado todo lo que en realidad ocurría pero, aun así, es la fuente más completa, precisa y directa para el conocimiento de la institución. 226

Los registros de actos comunes de los diputados del reino son ricos en suministrar datos sobre la conclusión de las sesiones de Cortes, la puesta por escrito del notario de Cortes y la entrega de un ejemplar destinado al archivo del reino. Algo que también el volumen foral recoge frecuentemente. En el registro de las Cortes celebradas en Alcañiz y Zaragoza bajo la regencia de la reina doña María en 1441 y 1442, se hacía una alusión explícita a esta circunstancia: "Acto, que dentro de seys meses el notario de la Cort haya de entregar a los diputados copias auténticas de los processos de las Cortes». En términos generales, se ordenaba que, una vez

225 Esteban Sarasa (1989), p. 335.

226 Ana Hernández Calleja (1991), p. 62. 
concluidas las Cortes, su notario debía hacer una copia corregida y firmada de todas las deliberaciones y acuerdos. Esta copia del registro debía ser facilitada a los diputados del reino mediante carta pública de entrega: «La qual copia los ditos Diputados en sí hayan a recebir e meter aquella en el archiu del dito Regno por conservación de la indemnidad del Regno sobredito mediant carta pública». ${ }^{227}$ La elaboración de varias copias del mismo acto jurídico (la reunión de Cortes) tenía una clara intención de preservación documental, dentro de un no menos explícito ejemplo de estrategia de la memoria desarrollado en el reino: asegurar la existencia de una copia en caso de que la del Justicia se quemase o perdiese: «A fin que si los ditos registro o registros fincantes e estantes en poder del Iusticia se cremarán o en qualquiere manera se perderán, la dita copia de los ditos registro o registros en el archiu del dito regno puesta e conservada haya tanta fe como el processo por el dito notario actitado». ${ }^{228}$

Registros de pólizas y asistencias

Serie de hacienda. Generalidades. El control de la asistencia de los diputados se llevaba en estos libros. Consistía en un registro de las asistencias de los diputados y demás oficios del reino cada día laborable al palacio de la Diputación para despachar los asuntos que eran de su cometido. El absentismo de los oficios del reino llevaba aparejada la pérdida del salario de cada día que se hubiese faltado sin motivo. Al final de cada ejercicio, estos registros eran minuciosamente revisados para determinar qué sueldos debían entregarse íntegros y cuáles no. En este procedimiento de control de la hacienda tomaba parte fundamental el inquisidor de cuentas: "Conocen también si han residido o no los Señores Diputados en el Consistorio para quitarles del salario la pena que tienen por los días que faltan y cargarla al administrador o arrendador de la Generalidad». ${ }^{229}$

De estos libros se deducían, por tanto, las jornadas en que los diputados habían asistido a sus oficios para contabilizarlas y pagarles en función de su asistencia. En ellos, el secretario y notario de los diputados daba fe de que asistían diariamente a los consistorios y juntas que eran de su obliga-

227 Savall y Penén (1866), vol. 2, p. 297.

228 Ibídem.

229 Del officio, poder y jurisdición de los Ilustrísimos Señores Diputados del Reyno de Aragón, B.N.E., ms. 8380, f. 263. 
ción. Y también constaban los libramientos o pólizas que se despachaban para los pagos menores que de las rentas del reino debían hacerse con arreglo a lo dispuesto por fueros y actos de corte. De esta serie se derivan por tanto consecuencias económicas directas, puesto que tanto el control de las asistencias como las pólizas para pagar cantidades menores conllevan un desembolso económico en concepto de satisfacción de un pago.

Con respecto a las pólizas, era competencia de los inquisidores de cuentas saber «si las pólizas despachadas por los Señores Diputados contra el administrador o arrendador de la Generalidad están firmadas de cinco Señores Diputados en su caso y de ocho en el suyo [...] y si han mandado pagar los Señores Diputados alguna cantidad más de las permitidas por los Fueros y Actos de Corte». ${ }^{230}$ Las pólizas constituían por tanto órdenes de pago sometidas al control fiscal de los inquisidores de cuentas.

\subsection{Propuesta de cuadro de clasificación del fondo}

La clasificación archivística constituye la fase crucial de la organización de los documentos. La primacía de la clasificación sobre cualquier otra actividad organizativa ha sido reiteradamente destacada por la teoría archivística. Para Cruz Mundet, clasificar «consiste en agrupar jerárquicamente los documentos de un fondo mediante agregados o clases, desde los más amplios a los más específicos, de acuerdo con los principios de procedencia y orden original». ${ }^{231}$ La materialización evidente de la clasificación se concreta en la construcción del cuadro de clasificación como instrumento que permite la identificación de los documentos atendiendo a las funciones y órganos de la institución productora de aquéllos. Como indica el profesor Esteban Navarro, «la materia de los cuadros de clasificación de fondos de archivo está compuesta por un conjunto de términos que representan órganos administrativos o acciones propias de una entidad física o moral, cuya estructura reproduce, respectivamente, la estructura orgánica de la entidad concreta que ha generado el fondo o las acciones que han motivado la producción de los documentos». ${ }^{232}$ Finalmente, para

230 Ídem.

231 José Ramón Cruz Mundet (2001).

232 Miguel Ángel Esteban Navarro (1997). 
Martín Pozuelo el cuadro de clasificación de fondos de archivo se convierte «en la pieza fundamental de la doctrina archivística y el punto de partida de su propia praxis: en consecuencia, no es solamente instrumento fundamental del archivero sino, al mismo tiempo, instrumento de conocimiento general». ${ }^{233}$ Como síntesis de todos estos conceptos, y a fin de clarificar lo que se entiende por cuadro de clasificación, Michel Roberge ofrece una definición de éste: «estructura jerárquica y lógica que refleja las funciones y las actividades de una organización, funciones que generan la creación o recepción de documentos». ${ }^{234}$

La propuesta de clasificación de documentos emanados de la Diputación del reino de Aragón debe atender a los elementos, estructura, fundamentos y metodología que conforman la construcción del cuadro de clasificación archivística. Por ello, el fundamento que preside el cuadro de clasificación debe ser la reconstrucción del orden original, basado en el sistema de producción documental y formado por tres principios científicos: el principio de procedencia, el principio de respeto de la estructura archivística y el principio de respeto del orden natural.

En cuanto a su construcción y eficacia operativa, el cuadro de clasificación debe atender a una serie de reglas, como la coincidencia del cuadro con una identificación precisa del fondo, la estructuración de las clases de acuerdo con el modo de producción documental, la naturalidad de las divisiones, la exhaustividad de las clases, la aplicabilidad de las clases y la flexibilidad estructural. De la aplicación de estas reglas se derivan los principios de gestión enunciados bajo los conceptos de delimitación, objetividad y consistencia. El primero de ellos hace referencia a la necesidad de que el cuadro de clasificación mantenga perfectamente definidos los límites funcionales y temporales de todos los documentos que componen el fondo de archivo. La delimitación se deriva de la identificación de las tipologías documentales a partir del estudio de la historia y estructura de la institución y también del reflejo de todos sus órganos o acciones a lo largo del tiempo con un criterio de exhaustividad. La objetividad del cuadro de clasificación se basa en la inclusión de las clases documentales justas y precisas, es decir, aquellas estrictamente nece-

233 Mari Paz Martín-Pozuelo (1996), pp. 140-141.

234 Michel Roberge (1990), p. 14. 
sarias para clasificar el fondo de acuerdo con el modo de producción de los documentos. Y por tanto, se deben evitar las excesivas subdivisiones y también las clases a las que no se pueda atribuir ningún documento. Por último, la consistencia del cuadro está cimentada en la capacidad que éste tiene de adscribir segura y precisamente todo documento a una clase, eliminando la posibilidad de pertenencia a otra. Por ello es necesario establecer los vínculos de los documentos atendiendo al modo de ser producidos, de acuerdo con los órganos administrativos generados o con las acciones que los han propiciado y el trámite administrativo seguido para su elaboración.

En cuanto a las posibles tipologías de cuadros de clasificación de fondos documentales de archivo, se dividen en orgánicos, funcionales o mixtos. Por lo general, el cuadro funcional otorga mayor precisión y estabilidad que el orgánico, sujeto a las variaciones estructurales de toda institución. Constituye un sistema objetivo, por cuanto refleja la estructura organizativa de la institución productora. La preferencia por el sistema de clasificación funcional se basa en que aporta mayor precisión y estabilidad que la clasificación orgánica, sometida ésta a los vaivenes y cambios en la estructura administrativa sufridos a lo largo de la historia de la institución. Así, las variaciones en las dependencias administrativas y en las acciones de una institución no impiden garantizar la continuidad de las series. De hecho, las funciones desarrolladas por una institución pueden variar de magnitud a lo largo de la historia institucional, pero generalmente permanece su esencia y naturaleza, ya que constituyen el fundamento último que otorga razón de existir a la institución estudiada. ${ }^{235}$

Con respecto a la clasificación de los documentos generados por la Diputación del reino de Aragón, existen varias propuestas con desigual alcance, derivadas generalmente del ya lejano trabajo de Ibarra (1909). El censo guía de archivos españoles y la página web de la Diputación Provincial de Zaragoza ilustran varios cuadros de clasificación. Los intentos clasificatorios de Ángel Canellas ${ }^{236}$ han sido continuados por Blanca

235 Miguel Ángel Esteban Navarro (1997). José Ramón Cruz Mundet (2001) indica que «la clasificación funcional se sustenta en la naturaleza de los documentos, de acuerdo con la cual define las series. Asimismo, es objetiva como lo es el criterio empleado, por cuanto las actividades, las funciones y las acciones, derivan de los fines inherentes a la entidad [...]».

236 Ángel Canellas López (1979), pp. 9-11, y (1981), pp. 96-97. 
Ferrer, quien en un informe publicado en 1995 y en la reciente guía del archivo de la Diputación Provincial de Zaragoza reproduce una propuesta clasificatoria basada en los trabajos anteriormente citados. ${ }^{237}$

Frente a estas propuestas, no basadas en el análisis directo de las series documentales generadas y reunidas por la propia Diputación en el archivo del reino, consideramos más apropiado seguir el método de reconstrucción de cuadros de clasificación de fondos de archivo que hemos sintetizado. Los principios de este método, aplicados a la Diputación del reino de Aragón, propician un cuadro de clasificación de los documentos generados en virtud de las funciones y competencias forales de dicha institución desde mediados del siglo XV hasta comienzos del XVIII. Para la confección de ese cuadro de clasificación funcional se han seguido los siguientes criterios:

1. El cuadro se divide en un primer nivel en tantas clases como funciones desempeñó la Diputación del reino de Aragón, que corresponde con las secciones. Estas clases hacen referencia a las funciones habitualmente comunes a las instituciones del Antiguo Régimen: funciones derivadas de la toma de decisiones y de gobierno, de la administración de sus asuntos, de la gestión de los recursos económicos y de la aplicación de las competencias judiciales. Estas funciones son propias de muchas instituciones de la Edad Moderna, en las que la simultaneidad de competencias de gobierno, administración, hacienda y justicia era una característica común. Por consiguiente, el conjunto de funciones desplegadas por la Diputación aragonesa se puede articular en torno a cuatro apartados: gobierno, administración interna, hacienda y justicia. No obstante, ello no impide que, debido a la complejidad institucional adquirida por la Diputación a lo largo de los años, las series documentales estudiadas recojan actividades vinculadas con lo que en la actualidad denominamos con el término servicios, tales como el comercio del reino, la salud pública, las obras públicas, la beneficencia, las manifestaciones artísticas, etc.

2. Los niveles inferiores articulan funciones más específicas y se establecen tantos niveles como sean necesarios, aunque limitando el número de subdivisiones para evitar la creación de agrupaciones documentales muy artificiosas que compliquen en exceso el cuadro de clasificación.

237 Blanca Ferrer Plou (1995) y Blanca Ferrer Plou y Alicia Sánchez Lecha (2000), pp. 44-59. 
3. El último nivel de la división está reservado a los trámites que se corresponden con las series y subseries que se fijan mediante el análisis de los tipos documentales. ${ }^{238}$

4. Quedaría un conjunto documental especial compuesto por todos aquellos documentos originales y copias que conformaron a lo largo de los años la denominada "alacena de Zurita", o armarios donde se custodiaban materiales documentales de muy diversa procedencia y naturaleza, que constituían más bien una colección. Únicamente la serie de los cuadernos originales compuestos por los cronistas, y que eran los manuscritos que quedaban en poder de los diputados, constituiría la tipología documental generada en el ejercicio de las competencias de los cronistas como cargos dependientes del gobierno de los diputados.

1. Gobierno.

1.1. Comunicación.

Registros de cartas misivas y responsivas.

1.2. Disposiciones emanadas.

Bastardelos de actos comunes.

Registros de actos comunes.

1.3. Disposiciones recibidas.

Bulas y privilegios.

Firmas.

Registros de Cortes.

1.4. Control del equipo de gobierno.

Matrículas de insaculados en los oficios del reino.

Cuadernos de las extracciones de los oficios.

2. Justicia.

Bastardelos de inquisidores de procesos.

Procesos de denunciación.

Procesos por fraudes.

Procesos de habilitación de infanzonía.

Procesos de insaculaciones.

Procesos de sumarias informaciones.

Procesos de suplicaciones.

Procesos de «viedas» de panes y carnes.

238 Miguel Ángel Esteban Navarro (1997). 
3. Administración.

3.1. Archivo.

Índices y rúbricas del archivo.

Registro de entrada y salida de documentos. ${ }^{239}$

3.2. Patrimonio.

Libro inventario de los bienes de la Diputación.

3.3. Registro y control de población.

Fogajes.

4. Hacienda del reino.

4.1. Generalidades.

Libros de cuentas del general.

Libros de las tablas de las villas.

Registros de ápocas de salarios, comisiones y consultas.

Registros de pólizas y asistencias.

4.2. Ingresos extraordinarios.

Cabreos de censales.

Libros de intimas de censales.

Registros de ápocas de pensiones de censales.

4.3. Sisa.

Cuadernos de deliberaciones de la junta de sisas.

Registros de ápocas de la sisa.

4.4. Gastos extraordinarios.

Cuadernos del pagador de los tercios.

Libros de expensas menudas.

Procesos de consultas.

239 A.D.P.Z., ms. 338: Registro de entrada y salida de documentos del archivo de la Diputación del reino (1615-1710). 



\section{EL ARCHIVO DE LA DIPUTACIÓN DEL REINO DE ARAGÓN}

Para el conocimiento del carácter y la evolución histórica del archivo de la Diputación del reino de Aragón, se cuenta con diferentes textos, que se pueden agrupar en cuatro conjuntos. El primer grupo de textos está formado por disposiciones jurídicas de rango legal superior: fueros, observancias y actos de corte, que otorgan carta de existencia al archivo y regulan su funcionamiento, ya que la organización y el mantenimiento del archivo y del sistema documental de la Diputación aparecieron con regularidad como asuntos a debatir en las sesiones de las Cortes de Aragón a partir del siglo XV. El segundo conjunto se compone de textos de carácter administrativo generados por la Diputación: en su mayoría se trata de los registros de actos comunes, los cuales ofrecen regularmente noticias sobre la organización de las escrituras y la composición del archivo, entendido éste como pieza indispensable en el entramado burocrático de la institución aragonesa. Y el tercer grupo de textos está formado por descripciones arquitectónicas coetáneas o estudios histórico-artísticos posteriores que intentan reconstruir el edificio tras su destrucción en 1809. Y por último, se dispone de las informaciones que proporcionan una descripción global.

Las informaciones que proporcionan una descripción global del archivo generalmente indican su localización, la disposición de sus cajones, el mobiliario que componía la sala y la fecha de su creación o los archiveros que lo sirvieron en una época determinada. Estas descripciones extensas del archivo del reino son documentos específicos o bien se insertan como piezas documentales en el seno de tipologías más complejas, como expedientes, consultas o memoriales de archiveros que realizan un repaso his- 
tórico al depósito en que han servido o pretenden servir. De carácter más fragmentario y disperso son las noticias sobre el contenido general y la disposición del archivo vertidas por los cronistas aragoneses como asiduos investigadores de éste y por los eruditos aragoneses del siglo XVIII, que se ocuparon de él en algunas de sus obras más celebradas.

\subsection{Creación del archivo del reino (siglo XV)}

A pesar de la nebulosa informativa en la que se desarrolla la primitiva organización de la incipiente Diputación del reino a comienzos del siglo $\mathrm{XV}$, es innegable que la acumulación de competencias sustentadas en una jurisdicción regulada foralmente constituyó un proceso del que se desprendió una consecuencia lógica: la complejidad y especialización de las tareas burocráticas necesarias para sostener el aparato funcional de la institución. Escrituras y registros son así entendidos como consecuencia natural derivada de la función y la estructura de la Diputación y un medio técnico indispensable para el ejercicio del gobierno.

Los diputados aragoneses pronto fueron conscientes de ambos hechos. Así, ya data de las Cortes de Teruel de 1427 el primer intento de reglamentar la génesis y la custodia de los documentos producidos por la Diputación, mediante la orden de fundar un archivo para su conservación y organización, junto con los documentos procedentes de la corte del Justicia y los de la gobernación del reino, dotando, de este modo, de realidad jurídica al depósito que se habilitase para este fin en Zaragoza. ${ }^{240}$ Sin embargo, las Cortes de 1427 debieron de constituir un ensayo fallido de institucionalizar el archivo del reino, ya que las Cortes celebradas en Monzón en 1436 adoptaron de nuevo un acuerdo de índole similar, que regulaba de manera efectiva y definitiva la creación de un depósito que recogiese la memoria escrita del reino de Aragón. ${ }^{241}$

240 Jerónimo de Blancas, Sumario y Resumario de las Cortes celebradas en Aragón, B.U.Z., ms. 97, f. 125v-126r. Recogido en parte por Santiago Salord (1956), pp. 251-252: «Mandáronse cobrar las escrituras tocantes al Reyno, las Juras de los Reyes, las Congregaciones del reyno sobre la sucesión, el processo de Caspe y que se pongan en el Archiu. Dióse poder que se hiziesse la Diputación.

241 Savall y Penén (1866), vol. 2, pp. 215-216. Abad, Buesa y Lamana (1977), pp. 76 y 89 (nota 5). 
Pese a ello, todavía debieron de transcurrir algunos años hasta que el archivo comenzase a estar operativo, pues existen noticias de que en agosto de 1450 aún se estaban construyendo los armarios destinados a guardar los documentos dentro del recién construido palacio de la Diputación del reino en Zaragoza, como habían acordado las Cortes. ${ }^{242}$ De hecho, el acondicionamiento del mobiliario destinado a guardar documentos, libros y registros fue una tarea que afectó paralelamente a todas las instancias administrativas del palacio. En abril de 1476 se extendía carta de pago en concepto del mobiliario destinado a la escribanía de la Diputación: «Por quanto se es fecho pora la escribanía de la dipputación el tavlell, caxones e tavlas pora las escripturas». ${ }^{243}$

El intento de las Cortes de 1427 de formar el archivo del reino de Aragón es, pese a su fracaso, sumamente interesante, por dos razones. En primer lugar, porque la regulación, ubicación y dotación formal del archivo constituyó una de las medidas más patentes del proceso de consolidación de la posición institucional de la Diputación en el panorama político aragonés. Como indica J. Á. Sesma, «Uno de los argumentos que de manera más rotunda sirven de prueba para asegurar la permanencia y la continua pujanza en la vida activa del reino, de la Institución, es el establecimiento de un lugar propio donde celebrar sus reuniones y conservar adecuadamente sus archivos». ${ }^{244}$ Porque a fin de cuentas, como señala Antonio Castillo para la Alcalá renacentista, «el archivo se nos presenta como la clave de la burocracia política y administrativa. En el arca o en los armarios reside el poder de la memoria escrita». ${ }^{245}$

Y, en segundo lugar, las Cortes de Teruel de 1427 y las de Monzón-Alcañiz de 1436 marcaron un hito en la historia de la archivística aragonesa, por cuanto, aunque se acordó reunir en un mismo edificio la documentación procedente de las diferentes instituciones que regían el destino del reino —el monarca a través de la gobernación del reino, las Cortes a través de la Diputación y la corte del Justicia-, se contemplaba la división de sus fondos («archius», según la terminología de la época) impidiendo su mezcla. Esto constituye otro ejemplo de evidencia práctica del respeto a la procedencia de los fondos documentales siglos antes de su formulación científica

\footnotetext{
242 Santiago Salord Comella (1956).

243 Registro de actos comunes de 1475, A.D.P.Z., ms. 63.

244 J. A. Sesma (1977), pp. 42-43.

245 Antonio Castillo (1997), p. 255.
} 
[Cortes de 1427]

Mandáronse cobrar las escrituras tocantes al Reyno, las Juras de los Reyes, las Congregaciones del reyno sobre la sucesión, el processo de Caspe y que se pongan en el Archiu. Dióse poder que se hiziesse la Diputación: Dióseles poder que pudiessen hazer una casa dentro Çaragoça en el más alto lugar que les paresciesse de buelta de regola donde huviesse casas distinctas assí mesmo de buelta de regola con sus almarios para tener los processos y registros de la Corte del Justicia de Aragón, de la Governación y de la Diputazión del Reyno, y que se hiziesen copias de buena letra y en pargamino los registros de las Cortes del Reyno y aquellos signados y sellados en pendiente por el notario de la Corte en el dicho Archivo meter y cobrar todos esos registros y procesos de la Corte del dicho Justicia, los que eran de los Justicias passados donde quiera que se hallassen y hazellos poner con devido orden y con inventario en el Archiu. ${ }^{246}$

\section{[Cortes de 1436]}

Acto que se hagan archius, donde se hayan de poner los processos y registros de la Corte del Justicia de Aragón, y de la Governación, y Diputación; y nominacion del Notario, que ha de tener la llave y custodia de dichos archius: el qual no pueda dar traslado, sino con mandamiento, o del señor Rey, o del Rigent el Officio de la Governacion, o del Iusticia de Aragon: y que del archiu de los Actos de la Diputacion, tengan las llaves los Diputados, y del salario del Notario. Assi matex puedan expender, \& fazer expender, en fazer una casa dentro en la Ciudad de Çaragoça en el mas habil lugar que visto les será, de buelta de rejola, en do haya casas distintas, axi matex de buelta de rejola con sus armarios, para tener los processos, actos \& registros de la Cort del Iusticia de Aragon, \& de la Governacion dél, \& de la Diputacion, \& encara fazer copia de bella letra, \& en pergamino, los registros de las Cortes del Regno, \& aquellos sellados, \& signados en pendient, por el Notario de la Cort, en el dito archivo meter, \& cobrar todos los processos, \& registros de la Cort del dito Iusticia, y los que son de los Iusticias passados, do quiere que sian: \& fazer qualesquiere constreylas; \& compulsas, que necessarias seran cerca lo sobredito, \& meter \& fazer meter aquellos en devido siamento, \& con inventario en el dito archivo: De los quales archivos tienga la clau un escrivano, ó Notario apto, honesto, é de buena fama. El qual los Diputados que agora se crean, ó los qui por tiempo serán, eslian agora, \& quando vacará el officio del dito Notario. El qual no pueda dar traslat alguno, sino por mandamiento del Señor Rey, ó del Regente el officio de la Governacion, ó del Iusticia de Aragón. Pero del archivo de los Actos de la Diputación, tiengan \& devan tener las claves los Diputados del Regno. El qual escrivano haya de salario cada un año cincientos sueldos Iaqueses. Los quales se le paguen de las generalidades del Regno por el Administrador de aquellas sin otra cautela. ${ }^{247}$

246 Jerónimo de Blancas, Sumario y Resumario de las Cortes celebradas en Aragón, B.U.Z., ms. 97, f. 125v-126r. Recogido en parte por Santiago Salord (1956), pp. 251-252, n. 12.

247 Savall y Penén (1886), vol. 2, pp. 215-216. 
A partir de entonces, la corte del Justicia, como alto magistrado garante y defensor del ordenamiento jurídico y procesal aragonés frente a la justicia ordinaria, cimentó su actividad administrativa en el archivo de los procesos del señor Justicia, ubicado en la planta baja del palacio de la Diputación. Por su parte, los registros reales referidos en exclusiva al reino aragonés, generados por las oficinas del regente de la general gobernación, representante del rey en Aragón y encargado de aglutinar las tareas de gobierno y de justicia en ausencia del virrey, también fueron $-\mathrm{O}$, al menos, deberían haber sido- depositados en dicho palacio, según volvió a disponer un acto de las Cortes de Calatayud de 1461, el cual instituyó, además, la figura del archivero en un notario aragonés residente en Zaragoza. $^{248}$

Esta medida de concentración documental consistente en la existencia conjunta de varios depósitos en una misma sede institucional pero con independencia y separación de fondos, se repitió en posteriores disposiciones forales y fue una constante de la historia del archivo del reino, como se desprende de numerosos testimonios. Así, por ejemplo, fue corroborada en mayo de 1686 en los siguientes términos: "Los illustrísimos señores diputados an pasado a hazer fabricar como en efecto se an fabricado en las cassas de la diputación tres archibos: uno para los processos de la Audiencia, otro para los de la escribanía de la General Gobernación y otro para los de la Corte del Justicia de Aragón». ${ }^{249}$ En definitiva, la creación del archivo del reino se acopla perfectamente al principio de procedencia de los fondos de archivo que se formularía siglos después, ya que la producción documental de la Diputación se custodia en un archivo específico, sin mezcla posible con el resto de archivos del palacio del reino, aunque su gestión esté supervisada por la Diputación como institución titular. Es decir, se habilitan archivos diferentes para instituciones diferentes, aunque compartan el mismo espacio físico representado por el edificio de la Diputación o las denominadas «casas del Reino en Zaragoza».

248 El origen del archivo del rey en el reino de Aragón y su ubicación conjunta con el archivo de la Diputación han sido estudiados por Rafael Conde y Delgado de Molina $(1994 a)$ y $(1998 a)$; no obstante, todavía es un hecho por dilucidar si los registros reales fueron efectivamente depositados en el archivo del reino. Esto exige realizar una investigación sobre la gobernación general de Aragón, la Audiencia de Aragón y los modos de producción documental, similar a la realizada para la Diputación del reino.

249 Registro de actos comunes del año 1685, A.D.P.Z., ms. 584, f. 153. 
Con las disposiciones de 1427 y 1436, las Cortes de Aragón adoptaron una medida similar a la tomada por otras instituciones coetáneas o posteriores en toda Europa. De hecho, a partir del siglo XV los depósitos documentales cambian su naturaleza itinerante y dispersa por la concentración o agrupación física, que no orgánica, de todas las escrituras generadas por una institución o un conjunto de ellas en depósitos generales situados en un mismo edificio, con el fin de facilitar el acceso a una documentación cada vez de mayor volumen. Si tomamos como eje de referencia el palacio de la Diputación del reino, la solemnidad de la sede institucional aragonesa descansa también sobre la base de la agrupación de la memoria documentada de los asuntos referidos al reino aragonés. Por tanto, no resulta casual que en el magno palacio se encuentren los archivos de las instituciones regnícolas y monárquicas que «entienden y gestionan» asuntos relativos al reino, concentradas en la caput regni.

\subsection{Ubicación y descripción del archivo (siglos XVI-XVII)}

La habilitación física de un espacio destinado a la ubicación de los cada vez más numerosos "papeles» del reino corrió paralela a la construcción del propio edificio de las instituciones aragonesas, conocido desde mediados del siglo XV como las "casas del reino». En nuestros días, sin vestigios arquitectónicos del palacio, la traza del edificio se observa únicamente a través de las famosísimas vistas coetáneas de Anton Van Wyngaerde y Juan Bautista del Mazo y Velázquez. Una obra de excepcional valor para formarnos una idea de la situación y la riqueza del palacio a fines del siglo XVII es la descripción de la sala real del palacio de la Diputación compuesta por Diego Dormer tomando como base las inscripciones de los retratos reales elaborados por el cronista Blancas. ${ }^{250}$ A fines del siglo XVIII y comienzos del XIX, el palacio sigue siendo objeto de atención con menciones puntuales a su destrucción en la obra escrita por Faustino Casama-

250 Innscripciones latinas a los retratos de los Reyes de Sobrarbe, Condes antiguos, y Reyes de Aragón, puestos en la Sala Real de la Diputación de la ciuad de Zaragoça... traducidas en vulgar... por Don Martín Carrillo, Abad de la Real Casa de Montearagón, con la descripción de la Sala, y otras noticias... por el Doctor Diego Iosef Dormer, Zaragoza, Herederos de Diego Dormer, 1680. 
yor. ${ }^{251}$ También las guías y gacetas que poblaron el ámbito tipográfico del siglo XIX ofrecieron diversas noticias con desigual grado de alcance en torno al archivo del reino. ${ }^{252}$ Con el inicio del siglo XX aparecen los primeros trabajos dedicados al estudio artístico y arquitectónico del palacio. El texto de Ximénez de Embún reproduce en gran medida lo sabido desde Dormer. ${ }^{253}$ La obra de Abizanda y Broto trata de ofrecer, aunque de forma dispersa, algunas noticias sobre las características arquitectónicas de la construcción. ${ }^{254} \mathrm{El}$ análisis artístico del palacio ha sido continuado por Ángel San Vicente Pino, ${ }^{255}$ Carmen Gómez Urdáñez ${ }^{256}$ y María del Carmen Lacarra, quien estudió las características mudéjares de la construcción. ${ }^{257}$ En la misma línea se sitúan los trabajos de Guillermo Redondo, quien aporta un mayor conocimiento sobre las características arquitectónicas de la sala del archivo a través de la publicación del documento de inspección y tasación de los trabajos efectuados en dicha dependencia en 1694. ${ }^{258}$ Finalmente, un trabajo algo más reciente abordó el estudio del edificio desde una perspectiva arqueológica. $\mathrm{Al}$ interés de este nuevo enfoque debe sumarse la importante puesta al día de las fuentes descriptivas del palacio, con especial atención a los escasos restos arquitectónicos salvados

251 El diario de Faustino Casamayor se compone de un total de 37 volúmenes manuscritos, actualmente custodiados en la Biblioteca Universitaria de Zaragoza. En ellos se da cuenta diaria de los principales sucesos acaecidos en Zaragoza entre 1787 y 1833.

252 Guía de Zaragoza (1860), p. 57: «Archivo del Reino: este curioso e interesante archivo se hallaba establecido en el antiguo palacio de la Diputación fundado en 1437 por Don Alfonso V, y después Audiencia, cuyo suntuoso edificio fue devorado por las llamas en la guerra de la Independencia, desapareciendo así en un momento la infinidad de obgetos [sic] preciosos que contenía y entre los que descollaban la galería completa de Reyes y Justicias de Aragón, y multitud de manuscritos y documentos célebres, testimonio vivo de nuestras brillantes glorias y de los heróicos hechos de la antigua monarquía aragonesa. En tan voraz incendio sólo pudieron salvarse algunos papeles, que para su custodia se entregaron al entonces interventor de ejército Don Narciso Meneses y que deberán existir en el archivo de la misma intervención de esta ciudad».

253 Tomás Ximénez de Embún (1901), pp. 30-32.

254 Manuel Abizanda y Broto (1917).

255 Ángel San Vicente Pino (1981) y (1991). En estas obras se da cuenta de un gran número de documentos procedentes del archivo de protocolos notariales de Zaragoza y del archivo de la Diputación Provincial de Zaragoza referidos a diversos y muy notables aspectos artísticos del palacio.

256 Carmen Gómez Urdáñez (1987), vol. 1, pp. 110-134 y vol. 2, pp. 156 y 367, y (1993), p. 110.

257 María del Carmen Lacarra Ducay (1981).

258 Guillermo Redondo Veintemillas (1981a), (1981b) y (1981c). 
tras el incendio de 1809 y conservados actualmente en el Museo Provincial de Zaragoza. ${ }^{259}$

El aspecto externo del palacio del reino, reflejado en un pequeño grupo de vistas y representaciones pictóricas, nos permite conocer muy parcialmente cómo era la sede de la Diputación. ${ }^{260}$ Con respecto a su interior, la documentación generada por el propio consistorio desde el siglo XV es fundamental para intentar reconstruir virtualmente el edificio y sus dependencias. ${ }^{261} \mathrm{El}$ edificio dio la bienvenida a cuantos viajeros y personalidades atravesaban la ciudad desde su entrada por la fachada del río Ebro. Y numerosas fueron las expresiones de alabanza vertidas sobre el palacio de la institución aragonesa por visitantes de toda naturaleza. ${ }^{262}$ Indudablemente, también los autores patrios glosaron las excelencias de la construcción ${ }^{263}$ hasta llegar a los albores del siglo XIX, fecha en que, como consecuencia del segundo sitio puesto por las tropas napoleónicas, el edificio fue bombardeado y finalmente destruido. ${ }^{264}$

Como ocurriera con la rica decoración cerámica del palacio real de Valencia durante el reinado de Alfonso $\mathrm{V},{ }^{265}$ en el interior de las "casas del Reino en Zaragoza» se asiste a todo un microcosmos simbólico donde se mezclan colores, calidades de los materiales empleados en la construcción y decoración, elementos de ostentación conducentes en última instancia a proyectar la imagen propagandística en el más solemne foro de decisión de

259 A. Álvarez Gracia y J. F. Casabona Sebastián (1989).

260 Guillermo Fatás y Gonzalo M. Borrás Gualis (1974). L. F. Arregui (1952). Luis Boya Saura (1952). Manuel Lorente Junquera (1960).

261 Faustino Casamayor, Años políticos e históricos de las cosas particulares ocurridas en Zaragoza: 1782-1833, B.U.Z., mss. 106-142. Ángel San Vicente Pino (ed.) (1991) y Ángel San Vicente Pino (1991). Manuel Abizanda y Broto (1917).

262 La serie "Testimonios literarios de una ciudad bimilenaria» ha sido reunida por Juan Domínguez Lasierra y publicada en la revista Turia desde el número 31 (marzo 1995) hasta el 39 (1998). En el número 38 (1996) se recogen las opiniones de diversos viajeros galos que visitaron Zaragoza en el siglo XVII. Vid. además A. Ponz (1988), pp. 73 y ss. Es reprod. facs. de la ed. de Madrid, Viuda de Ibarra, 1788-1794. J. M. Quadrado (1886), pp. 404-405.

263 Fray Diego Murillo (1616). Jerónimo de Blancas (1680). Existe edición facsímil a cargo de Guillermo Redondo Veintemillas y Carmen Morte García, Zaragoza, Cortes de Aragón, 1996.

264 Fray José de la Huerta, Descripción de Zaragoza, [Zaragoza, 18 de mayo de 1806], B.N.E., ms. 2721, f. 45r. Reproducida en Navarro Bonilla (1997), pp. 186-187.

265 Víctor M. Algarra Pardo (1996). 
la institución aragonesa dentro del palacio: la sala real o salón del patrón San Jorge. La adecuada conservación y limpieza de los elementos ornamentales del magno salón fueron tareas que los diputados no descuidaron. Con este fin, el día 11 de mayo de 1601 los diputados «nombraron a Pedro Sánchez de Ezpeleta, pintor y vecino de Zaragoza, con 8 libras jaquesas anuales para que a sus costas tubiese limpios y bien conservados los rótulos, blasones y quadros de la Sala Real de San Jorje».266

Indudablemente, el arte al servicio de la proyección institucional simbólica permite, en el seno de la Diputación del reino de Aragón, como indica Guillermo Redondo, el «estudio de espacios y de decoraciones para intimidar y reforzar el orden jerárquico y la autoridad». ${ }^{267}$

La solemnidad y magnificencia de la construcción y su cuidada decoración constituyen indudablemente el mejor ejemplo de los citados mecanismos de coacción suave frente a los atentos invitados y visitantes ocasionales de la sede institucional del reino. Incluso las soluciones arquitectónicas empleadas inciden en la caracterización del edificio como una construcción de gran categoría. ${ }^{268}$ De hecho, si consideramos que «los monumentos son documentos en piedra», y que los grandes edificios civiles sedes de las instituciones en la Edad Moderna proyectan una imagen de poder singular, el palacio de la Diputación del reino de Aragón se integra perfectamente entre los ejemplos arquitectónicos más sobresalientes. ${ }^{269}$

En conjunto, el edificio de la Diputación, y muy especialmente su salón real, presidido por la imagen del patrón San Jorge, obra de Ancheta,

266 Tomás Fermín de Lezaun, Apuntaciones Históricas..., B.N.E., ms. 9824, f. 14v.

267 En relación con las manifestaciones iconográficas y su simbolismo desarrolladas en el interior del palacio de la Diputación del reino, véase Guillermo Redondo Veintemillas (1981a), (1981b) y $(1981 c)$.

268 El famoso mirador de la Diputación, en el segundo piso, es un elemento sobre el que Carmen Gómez Urdáñez (1987), vol. 2, p. 111, escribe: «Sin duda la Diputación hubo de suponer un hito en la construcción y un modelo para las obras posteriores, pero cabe preguntarse si la fórmula excelente del mirador fue hallada con motivo del planteamiento de un edificio excepcional, si fue concebida como signo de categoría [...] ¡jes el mirador un elemento utilizado en origen como expresión de magnificencia?».

269 J. L. Rodríguez de Diego (1998b), p. 538. Vid. además J. L. Biget, I. C. Herve y J. Thebert, «Expressions iconographiques et monumentales du povoir d'état en France et en Espagne a la fin du moyen âge», en Culture et ideologie dans la genèse de l'état moderne, Roma, 1985, pp. 245-279. Para el caso de Zaragoza, Gonzalo M. Borrás Gualis (1995), pp. 363-378. 
constituyen otro de los elementos básicos del programa emblemático anteriormente aludido. ${ }^{270} \mathrm{La}$ rica decoración iconográfica, heráldica y mobiliaria de las estancias recordaba constantemente al espectador que aquel edificio y aquellas dependencias eran el espacio físico donde se reunía el poder del reino y donde tenían lugar los acuerdos tomados en virtud de las competencias institucionales de la Diputación y fijados por escrito. ${ }^{271}$ No es casual, por tanto, que también la memoria escrita del reino, custodiada en su archivo, se encuentre en la más suntuosa estancia del edificio.

Habida cuenta de que el edificio albergaba instituciones del monarca como la Audiencia Real, cabe también preguntarse si la decoración y las manifestaciones emblemáticas no están delimitando espacios dentro del propio edificio: separar en definitiva el ámbito físico de actuación de las instituciones privativas del reino de las que no lo eran. Además, el relieve escultórico con las míticas armas del reino, ubicado en una de las fachadas del palacio y situado a la vista de los ciudadanos y visitantes de Zaragoza, indicaba bien a las claras que aquel edificio era la sede de la institución representativa del conjunto del reino. ${ }^{272}$

A continuación, el espacio emblemático representado por la sala de San Jorge permite incluir algunos detalles que trasladan el pensamiento político y jurídico del reino al plano iconográfico. En primer lugar, uno de los elementos definitorios del salón de la Diputación estaba constituido por la serie de retratos de los reyes que fueron y eran en aquel momento de Aragón. ${ }^{273}$ Son de sobra conocidos los trabajos que analizan esta galería pictórica. Su carga simbólica, contenido e intencionalidad política tendente a subrayar la fidelidad del reino al monarca resulta también evidente. ${ }^{274} \mathrm{La}$

270 La consideración simbólica del patrón del reino y su proyección por los «representantes» de éste, los diputados, es analizada por Guillermo Redondo Veintemillas (1999), pp. 68-70.

271 La preocupación por mantener limpio y acondicionado el interior de la sala de San Jorge se documenta en el nombramiento del pintor Sánchez de Ezpeleta, como se ha visto anteriormente.

272 Estas bellas representaciones heráldicas han sido incansablemente reproducidas. Tan sólo indicamos el preciosismo de los recientes trabajos de Alberto Montaner Frutos (1995), p. 143, y la obra de Guillermo Redondo y Guillermo Fatás (1995), pp. 88-89, donde aparecen a todo color.

273 Jerónimo de Blancas (1680).

274 Aurora Egido (1979), p. 182: «La gloria de la monarquía española quedaba expresada en la disposición simbólica de las pinturas del Salón Grande del Buen Retiro y la de 
incorporación de la galería de retratos de los reyes a la decoración del salón del reino pretendía atraer la benevolencia de la Monarquía, puesto que el retrato se convertía en "vehículo de glorificación dinástica en toda Europa durante el siglo XVI». ${ }^{275}$ Sin embargo, la descripción del salón hecha por Dormer en la explicación histórica de las inscripciones de los retratos incide en los elementos básicos y distintivos del reino, su antigüedad histórico-jurídica y su representación simbólica.

Durante la última década del siglo XVII se realizaron importantes obras en el archivo, cuya constancia documental arroja también un interesante conocimiento de la sala donde se ubicaba. En 1680 ya se había intentado un traslado de todo el archivo por querer edificar una capilla bajo la advocación de la patrona del reino. Sin embargo, los inconvenientes provocados por este traslado y el más que probable daño que las escrituras pudieran sufrir, hizo que esta capilla quedase en un mero proyecto. Así, el abogado fiscal del rey presentaba un juicioso memorial en el cual se instaba a abandonar la idea y dedicar, eso sí, la cantidad presupuestada en beneficio del monarca. Finalmente, se optó por mantener el archivo en el mismo lugar en que había estado desde su creación, hacía aproximadamente doscientos años, si bien tras efectuar diversas reformas. Para su conocimiento es fundamental consultar el contrato de obras en el archivo del reino de Aragón, fechado en 1694 y publicado por el profesor Guillermo Redondo Veintemillas. ${ }^{276}$ A este expediente precedió el nombramiento de peritos y la elaboración de su informe acerca del estado del archivo en septiembre de 1693. ${ }^{277}$ En este proceso de finales del siglo XVII para adecentar la sala del archivo, se indicaban también las condiciones de iluminación del apo-

Aragón se singularizaba en la Sala de la Diputación sobre la que escribe Uztarroz. El retrato, es clara expresión de la singularidad exaltada por el Renacimiento y, a medida que el tiempo pasa, se impone como género dominante».

275 Carmen Morte, en la introducción de la edición de las Inscripciones latinas, p. 27.

276 G. Redondo Veintemillas (1981b).

277 Registro de actos comunes del año 1693, A.D.P.Z., ms. 601, f. 59r: «Sus señorías dixeron que atendido y considerado que la bóbeda del archibo de los papeles del consistorio está amenazando totalmente ruina por estar avierta toda ella por muchas partes y cargar sobre ella unos pilares que sustentan porción de suelo de la armería que es todo el buque de dicho archibo y cargar como carga el peso de las armas de dicha armería en y sobre dicho suelo, que por tanto confiando las illustrísimas de la buena pericia de Miguel de San Clemente y Gaspar Serrano, maestros albañiles vecinos Cesarauguste, les nombraban y nombraron en peritos y vissores para ver y reconocer dicho peligro». 
sento. Es más, los diputados consideraron en septiembre de 1693 que abrir una ventana para mayor iluminación del archivo implicaba dejar dos o tres días el hueco hasta que fuera ocupado por una ventana definitiva. El tiempo que estuviese la apertura provisional debía ser vigilado el archivo con mayor celo por parte de un "hombre de la casa», como lo era el portero Blas Asensio Monterde. Todas las piezas documentales que componen el expediente completo no escatiman detalles sobre la sala del archivo, y en especial la rica decoración de la estancia.

Sobre los contenedores de la documentación, también tenemos diversas noticias, una incluso coetánea de la construcción y habilitación de la sala destinada para archivo mientras se construía el resto del edificio. Así, según testimonio recogido por Santiago Salord, «En agosto de 1450 las paredes de la habitación destinada a archivo estaban desnudas, a falta de los armarios, que se estaban haciendo. Este contratiempo ocasionó, entre otras cosas, que las cajas que contenían los sacos con los nombres de las personas valederas para los cargos de diputados e inquisidor del Justicia no pudieran ser custodiadas en el archivo, como estaba determinado, debiendo ser guardadas en la cambra del cantón, cerrada bajo llave». ${ }^{278} \mathrm{El}$ hecho de que desde el primer momento de su construcción la sala destinada a archivo se amueblase con armarios y no con otro tipo de muebles receptores de documentación no es algo casual. La sustitución de los cofres y arquillas de todo tipo por armarios, receptáculos documentales más efectivos, es una práctica introducida con éxito ya en el siglo XIII en Francia. ${ }^{279}$

Los armarios donde se iban a colocar a lo largo de los años los registros emanados de la Diputación del reino de Aragón y sus oficios mostraban su contenido a través de una cartela o relación de lo contenido en cada uno de ellos. En realidad, se trataba de un fragmento de pergamino pegado en la cara interior de la puerta del armario, de tal manera que al abrirlo se conociese su contenido real. Según se indicaba en la Ydea de la disposición del Archivo del Reino, fechada en el siglo XVII, «En el reverso de la puerta de

278 Santiago Salord Comella (1956).

279 Paul Delsalle (1998), pp. 102-103: «L'armoire pour les archives est attestée dès le Moyen Âge occidental, mais uniquement dans les très grandes institutions. Dès le XIII ${ }^{\mathrm{e}}$ siècle on parle des armoires du roi pour désigner le mobilier qui protège les chartes des rois de France, à la Sainte-Chapelle». 
cada alacena, ha de haver un pergamino y en él escrito la memoria de lo que allí se contiene, para que fácilmente se pueda hallar lo que se busca». ${ }^{280}$

El archivo del reino llegó a tener un total de 110 armarios, de los cuales 88 estaban numerados con indicación de su contenido. Estos armarios contenedores de la documentación del reino causaban admiración, y así se recoge en cuantos memoriales y relaciones "por mayor y por menudo" se efectuaron del archivo, especialmente durante el siglo XVIII: «este Archibo se halla situado en el Centro de la Audiencia al pie de la sumptuosa Sala de San Jorxe, y sus papeles se hallan mui custodidos y cerrados en unos caxones primorosamente adornados». 281

Además de los armarios, en la sala del archivo se encontraban otros muebles auxiliares y objetos como los inventariados en $1598 .^{282}$ En cuanto a la sala del archivo, ocupaba una de las mejores estancias del palacio de la Diputación del reino, una vez superado el magno salón de San Jorge. La magnificencia de su construcción y el asombro causado por el contenido documental son asuntos continuamente indicados por archiveros y responsables de la custodia y organización documental a través de interesantes memoriales y relaciones generales.

José de Yoldi, responsable de la confección del inventario del archivo, elaboró una relación general en la que indicaba lo siguiente: «Tiene una

280 R.A.H., ms. 9/671, f. 31r-32r.

281 Memorial del archivero Martín Maza de Lizana (1745), A.D.P.Z., leg. 755-3, publicado en Navarro Bonilla (1996), p. 213. Ver apéndice documental, n. 10.

282 Inventario de los bienes de la Diputación, años 1593-1616, A.D.P.Z., ms. 270, f. 14r-14v: «QVARTO: De las cosas que hay en el Archivo del Reyno que está dentro de la Sala Real, que están a cargo de los Señores Diputados. Primo muchos Privilegios, Processos y otras varias y diversas escripturas, las quales por no haver inventario dellas no se ponen aquí en particular. Item una bacina de plata adonde se ponen los redolinos quando se haze la extraction de los officios del Reyno la qual tiene de peso. Item un vaso de plata dorado, si quiere urnia para dar agua el día de la extractión de los officios del Reyno, que tiene de peso ciento y treynta y seis onças, la qual está en una caxa cubierta de cuero negro. Item un libro escrito de mano intitulado Matrícula general de todos los inseculados en los officios de la Diputación del Reyno de Aragón, hecha Año M.D.LXXXXIIII. Item este libro de inventario pareció a los Señores Diputados que le hizieron, que esté recóndito en dicho Archiu, adonde los señores Diputados que sucederán manden continuar y escrivir lo que aquí adelante compraran del dinero del Reyno. Item tres arcas de madera adonde están recónditos todos los Redolinos de las personas que pueden sortear en los officios del Reyno, cuyas llaves están en poder de los Señores Diputados y del notario extracto. Y las llaves del arca donde están los redolinos de los contadores y inquisidores las tienen y guardan los inquisidores y su notario. Esto está todo en el archiu en 20 de Junio de 1598». 
sola puerta con tres cerraduras. Es de bronze con diferentes adornos del mismo metal por fuera, y barras de yerro que la aseguran por dentro; su tamaño es de diez palmos de alto y seis de ancho. Es una sala prolongada de 54 pies de largo y 18 de ancho con una ventana y rexa que toma su luz de la parte del norte sobre el río Ebro y otra en lo más elevado a la parte opuesta. Está fabricada con primorosa arquitectura en su bóveda, lunetos y cornisa; doradas tarxetas y distribuydas las armas de la Corona de Aragón; pintado lo demás con follage de buena mano». ${ }^{283}$ Finalmente, como testimonio de gran valor para trazar el panorama físico general de la sala del archivo del reino de Aragón, uno de sus últimos responsables, Felipe Fernández de Arias, se expresaba en términos similares:

Este archivo está a los pies de la Magnífica Sala de San Jorge: su puerta es de bronce con dos llaves y entrados en él, se reconoció ser una sala /bastantel grande /y regnal embovedada, con cornisa, pintura, filetes y adornos de talla dorados y dos escudos de Armas de Aragón y primitivas de Sobrarve: Ay una bidriera con rez de ilo de yerro y reja grande alta que toma luz de la parte de la ciudad y otra reja grande /abalconadal al piso con vista al río con bidriera /del todo inútill. Esta sala de archivo forma tres frentes: en el uno ay 24 cajones /bien afianzados a la parezl unidos, de madera, rotulados y 6 sin rotular; en el otro, 27 cajones rotulados o numerados y 8 sin rotular y en el otro, 29 rotulados o numerados y 16 sin rotular [[ni numerar]], que al todo componen 110 cajones [[unidos]] de los quales los 88 numerados [[y]] /o \rotulados están pintados y con filetes dorados y los 22 restantes sin filetes y algunos maltratados. ${ }^{284}$

\subsection{El archivo de la Diputación del reino de Aragón en el siglo XVIII}

Desde el punto de vista artístico, para el edificio de la antigua Diputación del reino de Aragón y Real Audiencia durante el siglo XVIII es necesario indicar la existencia de una información gráfica de excepcional interés. Ésta es la suministrada por el «Plano con secciones del edificio de la Audiencia, antes casas del Reino", fechado en 1756, donde es posible reconstruir la estructura interna del edificio y que, junto a las representaciones de Wyngaerde, Velázquez y Del Mazo, etc., anteriormente aludidas, ofrecen una aproximación a la imagen del edificio destruido

283 A.G.S., Secretaría y Superintendencia de Hacienda, leg. 539.

284 A.D.P.Z., leg. 755-11. 
definitivamente en $1809 .{ }^{285}$ Se da por cierto que el último acto oficial del consistorio de la Diputación del reino de Aragón antes de su total extinción, según se desprendía de los Decretos de Nueva Planta, fue la elaboración de un memorial en el que se suplicaba la abolición de estos mismos decretos, que venían a significar la práctica disolución de la foralidad aragonesa. ${ }^{286}$ A partir de entonces, el reino se vería inmerso en un profundo proceso de transformación de sus instituciones y organización política conducente a la unificación e integración con el resto de los territorios gobernados por la Monarquía borbónica. A efectos prácticos, es muy probable que la disolución de la Diputación tuviera lugar entre los días 11 y 15 de febrero de 1708, antes de proceder a la recogida de las alhajas y otros bienes que habían pertenecido a ella. ${ }^{287} \mathrm{El}$ segundo paso fue la creación de la Junta del Real Erario el 3 de abril de 1711, que en lo sucesivo se encargaría del cobro y administración de las rentas de Aragón hasta 1715, fecha en que se disolvió definitivamente esta Junta. 288

Desde el mismo momento en que la Monarquía asume directamente las competencias económicas y fiscales del reino, el recurso a la documentación generada por las antiguas instituciones "regnícolas» se va a convertir en una constante administrativa. En realidad no se trataba, por parte de la administración borbónica, tanto de conservar la memoria del reino de Aragón a través de la documentación procedente de sus instituciones fundamentales como de asegurarse un medio eficaz y una fuente de información de referencia para justificar y defender los derechos de la Monarquía en materia tributaria. El respaldo que la información documentada proporcionaba era imprescindible para llevar a cabo sus propósitos reformistas, que ineludiblemente pasaban por una reorganización del territorio con una finalidad esencialmente fiscal. De hecho, una de las preocupaciones iniciales de toda la reforma administrativa era controlar el aparato financiero del reino, y para ello la documentación

285 Servicio Histórico Militar, Sección mapas y planos, A-23-1, n. ${ }^{\circ}$ 2. Reproducido por Blanca Ferrer y Alicia Sánchez (2000), p. 17.

286 Antonio Peiró (1988), pp. 20-23. Vid. en general Jesús Morales Arrizabalaga (1986).

287 Vid. "Alhajas que tenía la Diputación en el momento de su extinción 1707», A.D.P.Z., leg. 755-5. Citado por Ana Ximénez de Embún González (1995), p. 227, nota 2.

288 Melchor de Macanaz (1879), p. 184. 
constituía el acervo informativo que permitía asentar las bases de la reorganización fiscal en Aragón. ${ }^{289}$ Éste era el ámbito en que la documentación podía jugar un papel dinámico en el procedimiento administrativo y fiscal. ${ }^{290}$

Se observa por tanto la valoración del archivo como instrumento no sólo al servicio de las instituciones aragonesas que lo crearon, sino también de la Monarquía borbónica y de los particulares, en especial del estamento nobiliar, puesto que series concretas como los registros de Cortes garantizaban los derechos de pertenencia a un estamento que gozaba de una serie de prerrogativas y exenciones fiscales. La eliminación o el descuido de la memoria escrita impedía reconocer y asegurar los derechos documentados. ${ }^{291}$

Testigos de excepción y ministros activos en el diseño teórico y posterior implantación de las estructuras administrativas de Felipe $V$ en Aragón fueron Tomás Moreno Pacheco, ${ }^{292}$ superintendente de Hacienda desde 1707 hasta 1711, y posteriormente Melchor de Macanaz, que desempeñaría los cargos de intendente de Hacienda y fiscal general de Felipe V. De su testimonio rescatamos la dificultad encontrada para acceder al antiguo archivo de la Diputación del reino con el fin de llevar a cabo sus investigaciones $^{293}$ acerca de la historia económica y las particularidades fiscales

289 Jesús Maiso González y Rosa María Blasco Martínez (1984), p. 16: «Esta medida apareció como un requisito imprescindible para que la Corona tuviese las manos libres para aumentar los impuestos y controlarlos directamente, al suprimir el organismo autónomo de gobierno y las finanzas, como había sido la Diputación del Reino».

290 Melchor de Macanaz (1879).

291 A.H.P.Z., Real Acuerdo, caja 18, leg. 2/5. Como se recoge en este informe de 1771, en el archivo del reino de Aragón «hay papeles de la mayor importancia a la Corona y a los vasallos de Vuestra Majestad en este Reyno, pues para justificar las familias sus respectivas noblezas y antigüedades, se valen de dichos papeles mediante certificaciones por los actos positibos y específicos que en aquellas se encuentran de haber asistido sus antepasados a las cortes».

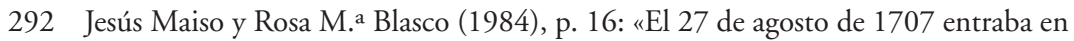
Zaragoza el superintendente general de las finanzas en Aragón, Thomás Moreno Pacheco. La superintendencia es la institución clave para la creación de nuevas imposiciones y para su control exclusivo y directo por parte de la corona. Moreno Pacheco introdujo el papel sellado, puso bajo su control las aduanas y el monopolio del tabaco — anteriormente administrados por la Diputación del Reino- y se encargó del estanco de la sal».

293 María Dolores Palú Berna (1986). 
del extinto reino de Aragón. ${ }^{294}$ El aumento del número de descripciones de carácter general hechas sobre el archivo del reino durante ese siglo es prueba también del interés que suscitaba su conservación. Archiveros y miembros de la administración se preocuparon por mostrar documentalmente su situación y magnitud.

Se cuenta con el testimonio de los memoriales de los archiveros Maza de Lizana (1745), Yoldi (1749), Lezaun (1754) y Fernández de Arias (1788). Los cuatro permiten conformar una idea cabal de la situación del archivo de la antigua Diputación del reino, ahora administrado por el nuevo gobierno.

La avanzada edad de Martín Maza de Lizana propició su relevo a mediados del siglo XVIII. A tal efecto, se elaboró en 1745 el expediente en el que se solicitaba que fuera sustituido por su hijo. En el memorial inserto se realizó una síntesis histórica del archivo del reino y de su contenido. Sin embargo, el resultado fue negativo para la pretensión de Maza y Villalba, su hijo, que fue sustituido en el cargo por don Pedro Lezaun. ${ }^{295}$

El 6 de diciembre de 1749, José de Yoldi (responsable del archivo de la antigua bailía y maestre racional de Aragón desde 1729 hasta su muerte en 1762) recibía la orden de que iniciase los trabajos de organización del archivo del reino de Aragón, que se materializaron en 1750 en su Yndice de los libros y papeles del Archibo general del Reyno de Aragón. ${ }^{296}$ Esta obra es en realidad un inventario y en algunas ocasiones catálogo de todos los documentos custodiados en el antiguo archivo del reino. ${ }^{297}$ Constituye

294 Melchor de Macanaz (1879), p. 201: «Hiciéronse dueños de los archivos del reino, impidiéndome el registrarlos y reconocer en ellos los intereses de la real hacienda y los que el reino repartía y cobraba de los vasallos, ni otro algún derecho, de modo que me vi precisado a estar día y noche examinando sus fueros, actos de las cortes y autores aragoneses que habían escrito sobre las rentas, para ver de dar algún paso en el reglamento de tales rentas".

295 Este expediente se analiza en Navarro Bonilla (1996).

296 A.G.S., Secretaría y Superintendencia de Hacienda, leg. 539: «En cumplimiento de la orden del Rey que con fecha de oy dirijo a Vuestra Merced sobre el reglamento de el Archivo de ese Reyno se dedicará mui particularmente a evacuar este assumpto avisando lo que necesitare para concluirlo con la mayor brebedad y formalidad. Y conforme vaya Vuestra Merced haciendo el índice, remitirá copia cada semana de lo que adelantare en él. Dios guarde muchos años».

297 El contenido íntegro de los 88 armarios, publicado por Diego Navarro Bonilla (2000a). 
una extensa pieza documental, de gran valor para conocer el contenido real del archivo. Por la fecha de su confección, se puede decir que es el último y más completo de los instrumentos de descripción hechos sobre el fondo de la Diputación. Uno de los primeros trabajos remitidos a Madrid el día 16 de diciembre de 1749 fue una relación "por mayor» o memoria general del contenido y situación del archivo del reino, básico para hacernos una idea de dicho depósito.

A estos testimonios se debe sumar el informe que el secretario del Real Acuerdo elaboró en 1771 sobre los diversos archivos custodiados en el palacio de la Diputación, así como las noticias sobre diversos archivos aragoneses adjuntas a la obra de Francisco Carrasco sobre los cuatro procesos forales de Aragón, fechada probablemente hacia 1776 y entre las que se hallaban referencias a los archivos de la antigua Diputación y bailía y maestre racional. ${ }^{298}$ Por las mismas fechas, Fernando José de Velasco elaboró un inventario general a modo de borrador de uso personal sobre las escrituras que halló en el archivo del reino con motivo de la comisión regia otorgada para elaborar una historia eclesiástica general. ${ }^{299}$

La relación de don Pedro Lezaun fechada en 1754 constituye otro instrumento descriptivo de la situación general del archivo, donde se detallan noticias sobre su fundación, andadura histórica, documentos custodiados y demás asuntos relacionados con él. ${ }^{300}$ Siguiendo con los memoriales y relaciones sobre el archivo elaboradas por los propios archiveros, el penúltimo archivero responsable de la documentación del reino, don Felipe Fernández de Arias, también escribió un a modo de borrador de la situación del archivo en 1788, que completa los datos conocidos sobre el depósito. ${ }^{301}$ En aquella ocasión, el antiguo archivo del reino fue inspeccionado por don Diego Navarro, contador principal del reino de Aragón, y por don Antonio Ximénez Navarro, intendente general del mismo ejército.

Asimismo, son de gran interés las numerosas noticias sobre el archivo del reino recogidas por los historiadores y eruditos aragoneses en el trans-

298 Este manuscrito se encuentra en la biblioteca de las Cortes de Aragón, con la signatura ms. L. 52.

299 B.N.E., ms. 1264.

300 A.D.P.Z., leg. 755-4. Vid. apéndice documental, n. ${ }^{\circ} 13$.

301 A.D.P.Z., leg. 755-11. Publicado en Navarro Bonilla (1996). Vid. apéndice documental, n. ${ }^{\circ} 18$. 
curso de sus investigaciones en librerías y archivos de Aragón. Tomás Fermín de Lezaun y Tornos (hijo del archivero Pedro Lezaun), el padre escolapio Joaquín Traggia, Ignacio Jordán de Asso, etc., accedieron en mayor o menor medida al contenido del archivo del reino y dejaron constancia de su situación y, en algunas ocasiones, detalle de su contenido. ${ }^{302}$ A pesar de que el edificio de la antigua Diputación pasó a albergar la sede de la Real Audiencia, el archivo del reino se mantuvo en su sala original sin sufrir especiales cambios.

Además de las relaciones generales que del archivo pudieron hacerse hasta el siglo XVIII, y que brindan numerosos datos sobre la organización concreta de las escrituras del reino, los expedientes de obras en el archivo proporcionan una imagen aproximada de lo que debió de constituir la sala del archivo, la disposición de su mobiliario, decoración y cuantos elementos se ubicasen en dicha habitación. Desde un punto de vista arquitectónico y de mantenimiento del edificio, el palacio de la Diputación del reino requería importantes reformas y obras para mantener su habitabilidad. En cuanto a los trabajos y remodelaciones realizadas en el archivo, tenemos noticia a través de las órdenes de pago libradas por los diputados a maestros albañiles en concepto de obras de restauración y decoración, y a través de los expedientes efectuados con motivo de las diversas rehabilitaciones del archivo, tendentes a solucionar el eterno problema de la techumbre y el suelo de dicha habitación. La sala del archivo del reino, como el resto de las dependencias del palacio de la Diputación, se vio sometida al deterioro ocasionado por el paso del tiempo. Además, el archivo descansaba sobre la iglesia de San Juan del Puente y en algún momento, como en 1713, se temió un desplome sobre su nave, ya que el mal estado de las bóvedas de la iglesia hacía que corrieran el riesgo de no poder soportar el peso de la estancia del archivo y hundir esta parte. ${ }^{303}$ Los numerosos expe-

302 Antonio Peiró (1998), pp. 89-93. En este trabajo se ofrece una lista de los eruditos del siglo XVIII y los archivos a los que accedieron.

303 A.H.P.Z., Real Acuerdo, caja 18, leg. 1: «la capilla del señor San Juan, contigua a las cassas de esta Audiencia amenaza ruina por estar sus bóvedas muy quebradas y las paredes maestras expuestas a caer en tierra; y que el archivo en donde están custodiados los papeles del Reyno puede también peligrar por estar sobre dicha capilla; y asimismo todos los texados de dichas se hallan muy mal tratados de calidad que quando llueve se introduce el agua y penetra por diferentes puestos de ellas». Para remedio de la situación, se contrataron los servicios de José de Estorgia, maestro de obras de Zaragoza, quien "visuró» las bóvedas de la iglesia corroborando su estado ruinoso y asegurando que «dichas quiebras 
dientes de obras acaban por hacer referencia casi en exclusiva a la urgente necesidad de mantener el tejado libre de goteras y otros desperfectos que amenazaban algunas zonas de la construcción. A pesar de ello, todavía las dependencias más sobresalientes seguían recibiendo la admiración y sirviendo para actos solemnes como la toma de posesión del presidente de la Real Audiencia del año 1784 o la de $1807 . .^{304}$

Pero durante el siglo XVIII no sólo continuó la atención y el cuidado del archivo del reino, sino que se retomó el proceso de reunión de las escrituras referidas a Aragón en el palacio de la Diputación, iniciado en el siglo $\mathrm{XV}$, como se aprecia en un texto del marqués de la Fresneda fechado en diciembre de 1749, donde se da noticia de la existencia de dos archivos localizados en las antiguas casas del reino. Estos depósitos no eran otros sino el de la Diputación y el de la bailía y maestre racional, archivo este último que había tenido durante la etapa foral el carácter de itinerante, puesto que había sido custodiado por los diferentes bailes y maestres racionales hasta que, a comienzos del siglo XVIII, se decidió su definitiva ubicación en el mismo palacio. En aquel informe se indicaban su situación actual y los responsables de su gestión. ${ }^{305}$

Sin embargo, el informe más extenso firmado por el secretario del Real Acuerdo en 1771 revela hasta qué punto el edificio albergó no sólo el archivo del reino, sino también el de la bailía y maestre racional, el de la cancillería real, el del registro real, el de la corte del Justicia y, posteriormente, el de la Audiencia de los Austrias y seguidamente el de la Audiencia borbónica, así como el archivo de la corte del zalmedina de la ciudad. ${ }^{306}$ Se com-

de paredes suben hasta los rafes de los tejados quebrantando las paredes que corresponden al archivo donde se guardan los papeles del Reino, que está encima de las vóbedas de dicha capilla». Sobre los expedientes de obras que se hicieron en el archivo del Reino durante el siglo XVII, véase Guillermo Redondo Veintemillas (1981b).

304 Faustino Casamayor, Años políticos..., B.U.Z., ms. 124, f. 148v.

305 A.G.S., Secretaría y Superintendencia de Hacienda, leg. 539: «El marqués de la Fresneda: Dize que en Aragón hay dos archivos generales: uno de libros, cabreos de rentas, papeles de quentas, fueros, autos de cortes, y otras noticias, que está a cargo de Don Pedro de Lezaun; y otro llamado de Vaylía que contiene las escripturas, derechos de los Reyes, su patrimonio y pertenencia a la Real Hacienda que dirige Don Joseph de Yoldi. Con cuyo motivo duda si la comisión dada a éste para arreglar el Archivo general se circunscrive sólo al suyo: y haciendo presente lo mucho que hay que hazer en ambos, es de parecer que Yoldi y Lezaun, trabagen respectivamente en sus archivos señalándoles alguna gratificación. Al final Todo Yoldi».

306 A.H.P.Z., Real Acuerdo, caja 18, leg. 2/5. Se analiza con más atención en el apartado dedicado a las descripciones generales del archivo. 
pletaba así el rico panorama archivístico que tuvo como marco arquitectónico la sede de las instituciones más representativas en el reino de Aragón durante el Antiguo Régimen. Es decir, la agrupación de los documentos emanados de las instituciones con competencias totales o parciales sobre asuntos aragoneses se cumplía solemnemente al habilitar los depósitos documentales, auténtico núcleo de la memoria escrita aragonesa.

\subsection{Avatares, incendio y dispersión del archivo del reino}

Durante los años de 1808 y 1809 se producen los dos sitios de Zaragoza por el ejército napoleónico, en los cuales el recrudecimiento de los combates culminó en enero de 1809 con el feroz e intenso ataque artillero que asoló la ciudad durante los últimos días de dicho mes. ${ }^{307}$ Finalmente, los artilleros franceses alcanzaron de lleno el palacio y comenzó así el incendio de todas sus dependencias. El hecho de que en su construcción se hubiese empleado gran cantidad de madera favoreció que en poco tiempo el palacio se consumiese pasto de las llamas. ${ }^{308}$

307 La destrucción de los elementos culturales y artísticos de un pueblo en un conflicto bélico es una constante histórica. Véase el reciente ejemplo de las totales devastaciones de las bibliotecas y archivos de la ciudad de Sarajevo, ejemplos cercanos en el tiempo de una práctica milenaria desde Alejandría. Vid. en general María Luisa Conde Villaverde y Rosana de Andrés Díaz (1996). Javier Tusell (1986). Francisco Gimeno Blay (1995).

308 Faustino Casamayor, Años políticos..., B.U.Z., ms. 125, f. 17v: [Zaragoza, 27 de enero de 1809] "Día 27: Este día nos vimos ia muy amenazados con el fuego tan furioso como seguido de nuestros enemigos [f. $17 \mathrm{r}$ ] no cesando un instante de caer bombas y granadas y balas rasas con mucho daño a los edificios y antes a las 8 de la mañana nos acometieron ponto [sic] de los puntos desde la Puerta Quemada a la del Portillo con tan terrible empeño que fue preciso tocar la generala a cuio sonido acudieron los paisanos y aunque se hizo la defensa más vigorosa pasaron la Huerva y se introdujeron en la Huerta de Santa Engracia al mismo tiempo que los de San Iosef se metieron en el molino de la ciudad en número de 40 que todos fueron muertos [...] lo que se repitió con maior fuerza a la una del día volviéndose a tocar la generala trabajándose otra reñidísima acción en todas las puertas que duró hasta la noche, en cuio día sucedió la desgracia lamentable del incendio de la Real Audiencia pérdida que jamás podrá ser resarcida quemándose sus dos archivos y con ello lo más precioso de los privilegios aragoneses; [...] [Zaragoza, 28 de enero de 1809] Día 28: Fue el fuego más horroroso que puede imaginarse excediendo a los días anteriores, caiendo muchas en las casas de la Parroquia de San Pablo por las que nos tiraban de la batería de la Bernardona [...] [f. 18r] El incendio de la Audiencia fue tan voraz que consumió toda ella y la magnífica sala de San Jorge con las escribanías y la maior parte de sus papeles, por todas cuias razones será entre unos de los más melancólicos de esta desastrosa guerra». 
Daudevard de Ferussac, oficial francés participante directo en el asedio de la capital aragonesa durante 1809, recopiló en un libro diario de su estancia en Zaragoza unos apuntes sobre la historia aragonesa y la cotidianeidad de su regimiento durante las jornadas de combate. ${ }^{309}$ Su narración de los acontecimientos, en los que participó activamente, surge como una fuente complementaria a las ya conocidas. En su narración sobre la contienda en Zaragoza subraya no sólo la magnificencia de la sede institucional del antiguo reino, sino también la importancia de diferentes bibliotecas y archivos de la ciudad a través de las notas que fue recogiendo durante las incursiones y saqueos a los que se vio sometida la ciudad. En un momento de la narración dedica varias líneas a glosar la excelencia del palacio de la antigua Diputación del reino. ${ }^{310}$

Otro oficial del ejército atacante consignó de forma lacónica la destrucción del edificio como consecuencia del bombardeo ininterrumpido: «En esta misma noche del 26 al 27 de enero [1809], nuestro bombardeo

309 J. Daudevard de Ferussac (1908). Este oficial francés llegó a ser jefe de estado mayor y subgobernador. Subrayamos como curiosidad su afición por rodearse de libros, probablemente obtenidos de los saqueos llevados a cabo por su ejército en Zaragoza, interés que revela cierto gusto bibliográfico no exento de ciertas reflexiones acerca del papel de las contiendas bélicas y su resultado en la pérdida del patrimonio documental del país atacado: Diario histórico..., pp. 1-2: «Cartas escritas durante el segundo sitio de esta ciudad, detallando su posición, historia, primer sitio y sitio actual. Campamento ante Zaragoza, a 23 diciembre 1808. Llegué el día 21, en la mejor ocasión: se batían. Ya te contaré, mi querido Félix, esta jornada así como las sucesivas, pero fiel a mi promesa de ponerte al corriente de cuanto concierne a Zaragoza, quiero primero, darte cuenta de las investigaciones que estoy haciendo sobre su historia y describirte su situación; cosas realmente necesarias para que aprecies bien la defensa que se dispone a realizar esta ciudad y la importancia de la empresa. Estoy admirablemente colocado para mis trabajos: Mi vivac está cerca del convento de los Capuchinos, donde he encontrado una hermosa biblioteca, un poco desordenada ciertamente por nuestros soldados, pero que contiene todos los autores antiguos y nacionales que pueden facilitarme los datos que busco. Te reirías de verme en el vivac, junto a dos docenas de mis soldados, rodeado en mi rinconcito, de multitud de volúmenes grandes y pequeños, los pies cerca del fuego, la espalda apoyada sobre un tronco de olivo, ojeando, compulsando, escribiendo entre el ruido de la fusilería y del cañón, y dejando con frecuencia la pluma para tomar la espada».

310 Ibídem, p. 55: «Pasemos ahora a los principales edificios de Zaragoza. La Diputación es uno de los más grandes; fue comenzada por Alonso $V$ en el año 1437 y acabada en 1450 (1: Crónica de Leonardo de Argensola; lib. I de sus Anales, cap. 64, nota del autor). Es el sitio donde se reunieron los Estados (Cortes) del reino. Había una sala superior donde estaban los retratos de los reyes de Sobrarbe, pequeño Estado del Norte de Aragón que tuvo sus reyes independientes. En el fondo de este salón hay un San Jorge de tamaño natural, en alabastro, obra de un escultor de mérito llamado Ancheta; aún se ven algunos retratos de los reyes de Aragón; pero este hermoso edificio ha sido quemado casi por completo». 
fue tan desastroso para la ciudad, [que] nuestras bombas causaron el incendio en varios lugares; la Chancillería del Palacio de Justicia fue reducida a cenizas». ${ }^{311}$ Siguiendo en la misma línea, Hernández de Morejón, con un lenguaje exaltado por la violencia bélica que había recaído sobre la ciudad, también se hizo eco del incendio del palacio incluyendo una brevísima mención, aunque no por ello carente de interés para nuestro propósito, a los archivos allí ubicados. ${ }^{312}$

A pesar de la destrucción, algunos restos del palacio se pusieron a salvo como testimonio de su magnificencia. ${ }^{313}$ Así, en noviembre de 1813 Felipe Sanclemente, administrador general de las aduanas de Aragón, informaba de "que en uno de los patios o lunas de la Casa de la Diputación antigua del Reyno de Aragón hay una columna esquisita y primorosamente labrada que podría servir para el referido Arbol que deberá colocarse en el moderno simulacro de la Cruz del Coso que VSI va a construir; el que sin duda alguna llamará la atención de los naturales y extranjeros». 314

El resultado del ataque se cifró no sólo en la derrota de la ciudad asediada en el plano militar, sino también en la pérdida de algunas de las señas de identidad fundamentales para comprender el pasado aragonés. ${ }^{315}$ La destrucción del palacio de la antigua Diputación del reino de Aragón

311 Louis François Lejeune (1840).

312 Sebastián Hernández de Morejón (1809), p. 29: «[El día 26 de enero] El enemigo continuaba abriendo minas y volando alternativamente las casas y calles de la ciudad. Mal satisfecho con el diluvio incesante de bombas y granadas, cuyo número pasaba ya de veinte mil, como si este extremo de ferocidad, desconocido entre los más bárbaros, no fuese bastante a saciar su rabia, echó mano de camisas embreadas y otros mixtos diabólicos, para añadir a las ruinas los incendios; Este expediente infernal, tan digno del regenerador de Europa, y del supremo protector de la felicidad de España, produxo en breve tiempo el efecto que se deseaba: entre la densidad del humo se traslucían las llamas que subían hasta las nubes: la campana anunciaba simultáneamente fuego, bomba y ataque: el magnifico edificio de la Audiencia, tan apreciable por su antigüedad y sus archivos, quedó reducido a cenizas. La Casa de Monje con su famosa librería, tuvo una suerte igual, y así alternativamente otras muchas».

313 Archivo del Palacio Real de Madrid, legajo 10955/4. A este respecto, el intendente de Aragón escribía en 1815: «Las Casas llamadas de la Diputación, en que existió la Audiencia y están quemadas por el estrago de una bomba sin que haya más que las paredes externas".

314 A.M.Z., caja 7829, olim 77-9.

315 José María Martínez Ferrer (1986), p. 50. 
privó a la ciudad de la sede de estas instituciones y, como consecuencia añadida, la documentación custodiada en los archivos del reino, de la bailía y maestre racional y de la Real Audiencia, con los fondos del Justicia, el registro y la cancillería, sufrieron un irreversible proceso de dispersión y pérdida, aunque por fortuna no total. El gran historiador de los archivos europeos Adolf Brenneke indicaba sucintamente la pérdida del archivo del reino en los siguientes términos: "Un altro archivio dell'Aragona, che si trovava a Saragozza (dal XV secolo), fu distrutto durante il periodo francese». ${ }^{316}$

La decisión militar de eliminar las sedes institucionales del pasado aragonés respondía a la voluntad de atacar los cimientos históricos de la colectividad asediada. Todo ello se podría insertar en una calculada operación de destrucción de la memoria, en este caso escrita, conducente a la destrucción de archivos, registros y de cualquier testimonio cultural del pueblo atacado, para eliminar la constancia jurídica que proporciona el documento. Así, es preciso subrayar el carácter de constancia documental y probatoria de derechos y privilegios que tenía el archivo del reino, cuya garantía jurídica corría el riesgo de perderse con el incendio. Además, la memoria histórica del reino recogida en los registros amenazaba con eliminarse para siempre. Por ello, el último archivero, Santiago Terreros, a buen seguro intentó organizar el traslado de las más de mil unidades documentales custodiadas en el archivo a otra sede más segura que el palacio de la Real Audiencia, lo cual, en parte, consiguió. ${ }^{317}$

Es, por tanto, imprescindible analizar la secuencia de actos que, inmediatamente después del incendio del palacio, afectaron directamente a las series documentales del archivo de la Diputación del reino. Porque, a pesar de que todo el conjunto documental no corrió la misma suerte que el espacio físico que lo albergó durante más de trescientos cincuenta años, no fue menos azarosa la dispersión y lamentable peregrinaje de la mayor parte de los fondos documentales allí custodiados. ${ }^{318}$ De hecho, en la actuali-

316 A. Brenneke (1968), p. 232.

317 J. Moneva y Puyol (1900): «cuias catástrofes no dieron lugar a acudir a apagar el incendio que prendió vorazmente, frustró todas las esperanzas de cortarlos pues, y aunque se procuró sacar algunos papeles por el actual archivero que entonces lo era D. Santiago Terreros, fueron muy pocos y aun estos tan mal custodiados que casi todos se perdieron o inutilizaron, cuia lamentable pérdida era llorada perpetuamente por la ninguna esperanza de su recobro".

318 A este respecto, véase Ángel Canellas (1968). 
dad, y a pesar de que la gran mayoría de los fondos salvados se encuentran en el archivo de la Diputación Provincial de Zaragoza, existen fondos disgregados en la Biblioteca Nacional de Madrid, la biblioteca de la Real Academia de la Historia, la Biblioteca General Universitaria de Zaragoza, el archivo y biblioteca de la Seo de Zaragoza y el archivo diocesano de la misma ciudad. ${ }^{319}$ Últimamente, durante los años 60 se consiguió recuperar varios registros de cartas procedentes de la Diputación, que se encontraban en manos de particulares.

En las interesantísimas copias de los oficios relativos al paradero del archivo del reino, se nos ilustran algunos puntos que permanecían difusos. Parece ser que, en efecto, en una situación desesperada de sitio militar y con la ciudad a punto del colapso, se procuró resguardar la documentación arrojándola desde las ventanas del palacio de la Real Audiencia a la plaza de la Seo: «los papeles de ambas instituciones fueron arrojados a la calle en medio de la esplosión de las bombas del enemigo, diseminados y recogidos por toda clase de personas que parece acudieron a irlos llevando a donde el riesgo permitiese a cada uno». ${ }^{320}$ Posiblemente, la proximidad de varios edificios capaces en la plaza de la Seo y sus aledaños, donde se encuentran la catedral y el palacio arzobispal, permitió la acogida provisional en sus dependencias de los restos salvados del incendio, y tal vez por esa razón todavía se encuentran en sus archivos piezas documentales extraviadas del archivo de la Diputación del reino de Aragón.

El intendente interino, y archivero desde marzo de 1815, Ramón de Les trasladó gran parte de los fondos documentales del antiguo archivo del reino de Aragón salvados de la destrucción en 1809 a su propio domicilio. ${ }^{321}$ Todas las circunstancias de la puesta a buen recaudo de los docu-

319 Ángel Canellas López (1981), p. 95: «Los restos del archivo histórico de la Diputación del Reino». Blanca Ferrer Plou (1995).

320 Copia del oficio remitido por Ramón de Les, intendente interino a 26 de noviembre de 1823. A.H.P.Z., Real Acuerdo, caja 18, leg. 12.

321 Ibídem. "Ya desde la muerte de su antecesor y haver quedado evacuada su casa, no tube otro arbitrio que llevarlos a la de mi alojamiento en la calle de las Vírgenes, reduciéndome con estrechez e incomodidad de mi familia y habiéndome mudado posteriormente a la que habito, tube que transportarlos conmigo y conserbarlos del mismo modo; hasta que en junio de 1820, la llamada Diputación Provincial reclamó el archivo como una de sus atribuciones y se me mandó entregarlo a su secretario; el qual vi que hizo conducir todo a la casa llamada del Reyno, porque así lo dispondría aquella corporación». 
mentos las hemos estudiado en un trabajo anterior. ${ }^{322}$ En suma, los fondos de la antigua Diputación del reino de Aragón, salvados azarosamente durante el incendio del palacio, habían sido trasladados a la sede de la intendencia de Aragón, el caserón de la aduana. Y hacia 1829 era urgente trasladarlos, habida cuenta de la necesidad de disponer de las salas del edificio de la aduana del reino. En 1837, como indican Ferrer y Sánchez Lecha, el encargado del archivo antiguo era Gregorio Montañés. ${ }^{323} \mathrm{Y}$ en 1862 se registra la petición cursada por el Estado Mayor del Ejército para elaborar un trabajo de investigación sobre el desarrollo de la guerra de la Independencia. ${ }^{324} \mathrm{El}$ esfuerzo por la recuperación del antiguo archivo del reino de Aragón sufrió una importante revitalización en la década de los años 60 del siglo XIX. Como indica Carmen Pescador del Hoyo, se asiste al (finalmente abortado) proyecto de creación de un Archivo General de Aragón, uno de cuyos fondos lo constituiría la producción documental de la antigua Diputación del reino. ${ }^{325} \mathrm{El}$ parcial e incompleto conocimiento de los documentos procedentes del antiguo archivo del reino de Aragón se ve compensado por el trabajo del archivero de la Diputación Provincial don Pascual Galbe y Sánchez Plazuelos y por don Eduardo Ibarra, que dio a conocer el contenido de las series documentales rescatadas del incendio de 1809. ${ }^{326}$ Actualmente, la corriente revitalizadora del patrimonio docu-

322 Diego Navarro Bonilla (1999a).

323 Blanca Ferrer y Alicia Sánchez (2000), p. 37.

324 A.D.P.Z., Libro de actas de la D.P.Z., n.o 30, años 1861 a 1863, f. 365: "[Sesión del 30 de octubre de 1862:] «Últimamente y leída la Real Orden espedida por el ministerio de la Guerra, trasladada el 28 de agosto último por el de la gobernación del reino a este gobierno de provincia y remitida a informe de esta corporación con el espediente de su referencia por el señor gobernador, en cuya real disposición se recomienda el facilitar al cuerpo de Estado Mayor del Ejército los datos que existan en los gobiernos de provincia y que puedan servir para la redacción de la historia de la guerra de la independencia encargada al mismo cuerpo; la Diputación acordó devolver el espediente de que se trata al señor gobernador, manifestándole que, puesto que en la parte de archivo donde se custodian los códices que han podido hallarse de la Diputación de este antiguo reino, hay según del espediente resulta, seis volúmenes referentes a la mencionada guerra; esta corporación no halla inconveniente alguno en facilitar al cuerpo de estado mayor de esta plaza, pero a condición de que las anotaciones y apuntes que de ellos se tomen sean hechas en la oficina que ocupa la secretaría en esta diputación; Secretario Pablo Sancho y Lezcano».

325 Vid. con más detalle el desarrollo de anteriores proyectos en María del Carmen Pescador del Hoyo (1981). A.G.A., Sección Educación y Ciencia, cajas 6962-6963 olim leg. 8176, doc. 87. En caja 6963, doc. 8176-87.

326 Eduardo Ibarra (1909-1910). 
mental aragonés, su correcta organización y puesta a disposición de la investigación parece agruparse en torno a algunas actuaciones y proyectos. Con respecto al fondo de la antigua Diputación del reino de Aragón, el área de cultura de la actual gestora de dichos documentos, la Diputación Provincial, anunciaba la puesta en marcha de un ambicioso proyecto de digitalización de las principales series que componen el fondo documental. ${ }^{327}$ Justo es, por tanto, que la memoria histórica del reino de Aragón reciba un tratamiento adecuado y una consideración al mismo nivel que la riqueza histórica y patrimonial de los documentos que formaron el registro documental del reino aragonés custodiado en el antiguo y solemne archivo del reino.

327 Heraldo de Aragón, 7 de diciembre de 2000. 



\section{EL ARCHIVERO Y LOS RESPONSABLES DE LA MEMORIA ESCRITA}

\subsection{Figura y funciones del archivero}

Paralelamente a la formación del archivo y establecimiento de sus funciones en el seno de la Diputación del reino, surge la figura del responsable de la custodia de las escrituras. Ya en las primeras disposiciones forales se indica claramente la existencia de un archivero único para tres fondos documentales: Diputación, corte del Justicia y gobernación del reino, al que se conoce como archivero del rey, de la gobernación y del Justicia de Aragón. La caracterización del archivero como guardián de la memoria escrita se refleja también en las disposiciones que obligan a que sea regnícola y que fije su residencia física en Zaragoza. Si Ayala debía fijar su residencia en Simancas, los archiveros del reino están vinculados directamente con la capital de Aragón.

Esta situación se mantiene a lo largo de la evolución de la Diputación, institución encargada del nombramiento, pago y supervisión de la actividad de archivero por medio de los inquisidores de cuentas: «Conocen asimismo [los contadores] si los Señores Diputados han residenciado o no cada año al archivero del Reyno sobre el cumplimiento de su oficio». ${ }^{328}$ Esta actividad estaba regulada en 1678 con un horario que abarcaba «todos los días jurídicos dos horas, una por la mañana, y otra por la tarde;

328 B.N.E., ms. 8380, f. 263. 
en el Verano de las nueve a las diez, y de las tres a las quatro; y en el Invierno de las diez a las onze, y de las dos a las tres». ${ }^{329}$

En cuanto a los gastos originados por su quehacer cotidiano, éstos debían sufragarse con fondos de las generalidades y se harían efectivos tras la conformidad de los vigilantes de llevar un orden para hacer frente a los gastos generales de la Diputación: los inquisidores de cuentas, es decir, los agentes fiscales de la hacienda interna y de gestión de la propia institución. 330

A tenor de la información que suministran los registros de la Diputación, el archivero del reino siguió actuando durante toda la etapa foral como custodio, y no tanto como organizador de las escrituras. La supervisión y el mantenimiento de las tareas de organización archivística eran realizados esencialmente por los secretarios de la Diputación. Incluso, en numerosas ocasiones las actividades de descripción y organización documental fueron llevadas a cabo por especialistas externos a la propia organización burocrática de la Diputación. Estas funciones rara vez fueron llevadas a cabo por el archivero, quien actuaba esencialmente como mero custodio de los documentos y fedatario de su contenido a través de la extensión de certificaciones de la más variada naturaleza.

Se vislumbra claramente una separación de funciones en el procedimiento administrativo que conduce a una especialización burocrática. La generación de los actos jurídicos documentados competía a las escribanías de la Diputación regidas por los notarios de plantilla. ${ }^{331}$ A continuación, un funcionario intermedio encarnado en la más o menos constante figura

329 Savall y Penén (1866), vol. 1, pp. 515-516.

330 Ibídem, p. 547: «Otrosí, que lo que se ofreciere gastar en la disposición, y compostura de dicho Archivo, y en poner por inventario los Processos de todas las Escrivanías, y restituirlos, se pague a expensas de el Reyno: Y que los Inquisidores de Cuentas devan pidirlas a los Diputados cada año de si han cumplido con la obligación que se les pone de haver de residenciar a dicho Archivero".

331 José Ángel Sesma (1977), pp. 91-92: «Dos son las funciones que se encomiendan a los notarios: la realización material del apartado burocrático de la Institución, y la actuación profesional, levantando acta y testificando los actos de los diputados y demás oficiales. Para la realización de ambos menesteres, la plantilla de notarios presenta dos categorías: los llamados notarios escribientes [...] y otro grupo de notarios [...] a los que se denomina de mandamiento [...]. Un tercer grupo ligado a la Institución, está formado por los notarios que desempeñan una misión concreta y regular en la Diputación, por la que per- 
del secretario de los diputados se encargaba de recoger los registros de las escribanías, remitirlos al archivo y sacar cuantos registros fueran necesarios por parte de los oficios del reino para fundamentar sus decisiones. Y finalmente, el archivero del reino, cuando no era el propio secretario, se limitaba a custodiar la documentación, sin participar activamente en la organización de las escrituras, en la elaboración de índices u otros instrumentos de descripción, al menos hasta que fue superada la etapa foral de las instituciones aragonesas.

No obstante, ya en la primera mitad del siglo XVII se asiste a la unión en una persona de los cargos de secretario y archivero del reino, dotando así de contenido la concentración de una mayor relevancia en la gestión documental por parte del secretario de la Diputación. Esta tendencia a involucrar al archivero en la gestión directa del archivo culminó con la administración borbónica, cuando los propios archiveros realizaban tareas de descripción y organización documental. La característica de custodio de la documentación se asocia claramente a la vinculación existente entre los cargos de archivero y secretario, pero también a la unión en una sola persona de estos cargos y el de alcaide del edificio. Así, en un principio las cuatro llaves de la puerta del archivo estaban en poder únicamente de los diputados, aunque con posterioridad habrá otra llave en poder del propio archivero. ${ }^{332}$

\subsection{Nómina de archiveros}

A continuación se traza una breve panorámica de los archiveros del reino de Aragón por orden cronológico. Junto a su nombre se indican las fechas extremas en las que se ha podido documentar su presencia, y datos sobre algún hecho protagonizado por ellos. Generalmente, los registros de actos comunes recogen el nombramiento del archivero, los pagos o aumentos de su salario, actos propios de su oficio y el reconocimiento de

ciben un sueldo, pero sin pertenecer a la plantilla de oficiales de la misma. Así, tenemos al notario archivero, instituido en las Cortes de 1436; es desempeñado por Juan Aznar Guallart y su función consiste en conservar el Archivo de los procesos, registros y demás escritos de las cortes del regente de la Gobernación y del Justicia, que se encuentran en las Casas de la Diputación».

332 Savall y Penén (1866), vol. 2, pp. 215-216. 
su capacidad para nombrar sucesor. Respecto a este último hecho, a veces se permitía por acto de corte que el archivero que llevara muchos años en el cargo determinara su heredero, pero siempre en una persona que fuera a satisfacción de los propios diputados. Se trataba de una práctica habitual en los oficios de la Diputación del reino de Aragón en el siglo XVII. Así, en el transcurso de los años nos encontramos con vínculos familiares más o menos estrechos entre quienes accedieron al control y custodia de los documentos del archivo.

\subsubsection{Los archiveros bajo la administración austríaca}

Juan de Salavert (1469-1473?)

Juan de Salavert inicia la lista de archiveros del reino de Aragón. Este notario, ciudadano de Zaragoza, es nombrado en los registros de actos comunes como responsable del archivo de los procesos y registros del regente «el Oficio de la Gobernación y del Justicia de Aragón».333

Juan Aznar Guallart (1475-1492, 1500-1513)

$\mathrm{Al}$ igual que su antecesor, se trata de un notario habitante en Zaragoza, que firma en los documentos oficiales como «detenedor del archiu de los processos, registros e otras escripturas de las Cortes, del Rigent el officio de la Governación et Iusticia de Aragón", quien recibe 500 sueldos anuales por su salario. ${ }^{334}$ En 1492, el cargo de archivero es suprimido por problemas económicos. ${ }^{335}$

Francisco Villanova (1497)

A 13 de noviembre de 1497 recibió 200 sueldos como archivero del reino por haber hecho copia de las ordinaciones del Reino. ${ }^{336}$

333 Registro de actos comunes del año 1469, B.N.E., ms. 17451, f. 73r. Registro de actos comunes del año 1470, A.D.P.Z., ms. 56, f. 116v. Registro de actos comunes del año 1472, A.D.P.Z., ms. 58, f. 82r. Registro de actos comunes del año 1473, A.D.P.Z., ms. 61, f. $128 \mathrm{v}$.

334 Registro de actos comunes del año 1486, B.N.E., ms. 17453, f. 51v-52r. Registro de actos comunes del año 1483, B.N.E., ms. 17452. A.D.P.Z., ms. 77, f 37v-38r. Registro de actos comunes del año 1475, A.D.P.Z., ms. 63, f. $61 \mathrm{r}$.

335 J. Á. Sesma (1977), pp. 92-93.

336 Registro de actos comunes del año 1497, A.D.P.Z., ms. 86, f. 25v. 
Juan Prat (1514-1544)

En 1525, el notario Juan Prat desarrolla un importante grupo de actividades burocráticas como «notario del archiu donde están los processos de la corte del Justicia de Aragón y como notario de los siete consejeros [...] y como numerador de las cartas de los libros de los administradores del general». En 1530 firma como notario de las causas criminales del reino, y en 1534 como «archivero del archiu de los processos y registros de la audiencia real del regno de Aragón». ${ }^{337}$

\section{Pedro López (1545-1559)}

Inicia una de las sagas más importantes dentro de los cargos administrativos de la Diputación del reino. Pedro López posee a mediados del siglo XVI los cargos de escribano principal y archivero de los procesos del Justicia y de la gobernación del reino. En 1549 firma como notario de los contadores electos. Tras su muerte le sucedió como escribano su hijo Miguel López, en "que el dicho su padre le recabó dicho officio de escribano principal y aunque es verdad que el assentar en los cabreos los censales que el reyno haze es de mucha confianza, empero es la muy mayor ser alcayde de la Dipputación y con este fin se le tiene assignado salario sobre las generalidades el qual es officio de tanta confianza, que no se puede fiar ni encomendar sino a persona tal como lo es dicho señor Miguel López». ${ }^{338}$ Los diputados nombraron a Miguel López en 1575 custodio de los libros impresos por la Diputación.

Jerónimo Andrés (1565-1592)

En las Cortes celebradas en Monzón el año de 1564 se recoge en los registros de actos la aprobación del aumento de salario de Jerónimo Andrés. ${ }^{339}$ Junto con el apellido López, los Andrés permanecen al frente del archivo hasta la primera mitad del siglo XVII. Jerónimo Andrés sigue disfrutando en 1565 del cargo de «archivero que soy del arquivio de los processos de la Corte del Justicia de Aragón y gobernación de este Reyno». ${ }^{340}$ En septiembre de 1568, Jerónimo Andrés recibió la orden de

337 Registro de actos comunes del año 1510, B.N.E., ms. 17454, f. 41v-42r.

338 Registro de actos comunes del año 1576, A.D.P.Z., ms. 231, f. 43v-46r.

339 Savall y Penén (1866), vol. 2, p. 586.

340 Registro de ápocas del año 1565, A.D.P.Z., ms. 197, f. 5v. 
copiar unas escrituras sobre la Inquisición. ${ }^{341}$ Sin embargo, en 1576 los registros de actos comunes establecen que el escribano principal Miguel López pueda «nombrar un lugarteniente suyo, con voluntad de vuestras señorías como lo es el muy magnífico Hierónymo Andrés, en quien concurren todas las calidades que se pueden dessear, según la experiencia lo ha mostrado, y podría este consistorio descansar en conciencia y justicia, pues se hiziesse por el orden devido». ${ }^{342}$ En las Cortes de Monzón de 1585, Felipe II concedió a Jerónimo Andrés la sucesión de su oficio de archivero en quien determinase, habida cuenta de la gran confianza ganada en el seno de la Diputación, pues hacía «más de treynta y tres años que sirve dicho cargo y officio y en el Consistorio de la Diputación, con toda satisfación, cuydado y diligencia». ${ }^{343}$ El 21 de marzo de 1592 se documenta el reconocimiento y nombramiento como sucesor de Jerónimo Andrés, muerto en 1590, de su hijo Lupercio en el cargo de archivero del reino. ${ }^{344}$ Sin embargo, al no ser notario todavía, queda de forma interina el notario Bartolomé Malo y a continuación Juan Escartín. ${ }^{345}$

341 Registro de actos comunes del año 1568, A.D.P.Z., ms. 205, f. 47r: «Me mandaron a mi dicho Jerónimo Andrés, su notario, que sacasse y sacar hiziesse todas las copias que necesarias fuessen de la executoria y provisión real de su magestad sobre las cosas de la Inquisición, la qual corporalmente está en poder suyo y en el archiu de la Diputación que fue dado en Madrid a diez y siete de julio próxime pasado del año presente; y entregar las dichas copias al excelentísimo señor don Hernando de Aragón, arçobispo de Çaragoça y lugarteniente general por su magestad en este Reyno».

342 Registro de actos comunes del año 1576, A.D.P.Z., ms. 231, f. 43v-46r.

343 Savall y Penén (1866), vol. 1, p. 420.

344 Lorenzo Ibáñez de Aoiz, Ceremonial..., B.U.Z., ms. 199. B.N.E., mss. 2922 y 987: «Gerónimo Andrés por su último testamento que fue dado y librado, cerrado y sellado en Çaragoça a 17 de octubre del año 1590 y por su muerte a 21 de diciembre del mismo año abierto y publicado mediante actos testificados por Hierónimo de Blancas notario Público del número de la ciudad de Çaragoça dispusso de su officio de archivero en Lupercio Andrés, su hijo y en 22 de Março de 1592 admitieron los Señores Diputados esta disposición y por no tener Lupercio Andrés la autoridad de notario nombraron hasta que él lo fuesse a Bartolomé Malo y después en 30 días del mes de Mayo de 1597 los Señores Diputados que entonces heran admitieron al Lupercio Andrés al exercicio de su officio y le entregaron las llaves del Archiu».

345 En agosto de 1552, Bartolomé desempeña diversas tareas administrativas en el seno de la Diputación. Entre ellas, la entrega en Monzón de diversos documentos a los diputados asistentes a cortes en Monzón. A.D.P.Z., ms. 689, f. 32v: «Luego que reçebimos la carta de vuestras señorías y mercedes con Bartholomé Malo, hizimos mirar en el archiu las bullas que por dicha causa piden, y assí habemos dado al dicho Bartholomé Malo dos bullas originales plúmbeas confirmatorias de los capitoles de la inquisición y principado de 
Juan Escartín (1593-?)

Notario del número de la ciudad de Zaragoza. Nombrado provisionalmente sustituto de Lupercio Andrés, cobra las cincuenta libras de su salario de archivero: «Por tanto, teniendo grande satisfación de la bondad y habilidad de Joan de Escartín, notario público de la ciudad de Caragoça y escrivano de mandamiento del Rey nuestro señor, le nombramos por administrador del officio de archivero de los procesos de la corte del Justicia de Aragón y governación de este reyno, y esto durante tan solamente el tiempo que el dicho Lupercio Andrés no llegare a tener autoridad de notario». ${ }^{346}$

\section{Lupercio Andrés (1597-1599, 1602-1612, 1620-1627)}

En 1598 Lupercio Andrés es conocido directamente como «archivero de la Diputación de este Reino». Tras un paréntesis de ocupación del cargo por Pedro López de Quinto entre 1599 y 1601, vuelve Lupercio Andrés en 1602 como archivero del reino y del Justicia. ${ }^{347}$ Como se observa en los registros de actos comunes y de ápocas de salarios, Lupercio Andrés ejerció el cargo de archivero de forma intermitente, hasta que en 1627 se documenta el pago de cincuenta libras por su salario de «archivero del Archivo adonde están los processos de la corte del Señor Justicia de Aragón y de la Governación». Como había ocurrido con su padre Jerónimo, las Cortes de 1626 dieron facultad a Lupercio Andrés para disponer de su oficio. $^{348}$ Sin embargo, ningún hijo suyo lo heredó y desconocemos en quién dispuso su cargo y si llegó a hacerlo.

Cathaluña, y una observancia del Papa Adriano, haunque aquella fue hecha ante de su pontificado siendo inquisidor general, los capitoles que se piden del año de diez y nuebe tocantes a la inquisición, no se han hallado en el registro de cortes del año de 19; es verdad que se a hallado en un registro de los actos comunes del reyno una copia signada que el dicho Bartholomé Malo estava de partida, no los puede llebar; probeheremos en que se saquen y los embiaremos con el primero que se ofreciere; a vuestras señorías y mercedes suplicamos que dichas bullas estén muy guardadas de tal manera que vistas por las personas que las han de ver, se buelvan a embiar a buen recaudo para que las bolvamos al archiu».

346 Registro de actos comunes del año 1591, A.D.P.Z., ms. 261, f. 52r-53v.

347 Registro de ápocas, comisiones y consultas año de 1612, A.D.P.Z., ms. 324, f. 7v. Registro de ápocas, comisiones y consultas año de 1606, A.D.P.Z., ms. 308, f. 32v.

348 Savall y Penén (1866), vol. 2, p. 386: «concede facultad al dicho Lupercio Andrés, para que por testamento, ó en otra qualquiere manera, y por otro genero de contracto en vida, ó en muerte, pueda disponer del dicho su oficio de Archivero en uno de sus hijos, el que mas quisiere, como sea persona á satisfacion, y contento de los Diputados del Reyno». 


\section{Pedro López de Quinto (1599-1627)}

En 1585 se dio facultad al escribano principal y archivero Miguel López para que dispusiese de sus oficios. Miguel López había desempeñado el cargo de escribano durante más de cuarenta años. ${ }^{349} \mathrm{Y}$ por testamento nombró a su hijo Pedro. En 1599 se nombra a éste como encargado para que saque del «archiu de la Dipputación y presente Reyno unas escrituras» que están a su cargo como archivero y escribano principal del consistorio. ${ }^{350} \mathrm{Su}$ intensa gestión dentro de la Diputación se verá ensombrecida por un descuido, al dejar abiertas las puertas del archivo del Justicia. De hecho, en mayo de 1615 le suspendieron de salario y oficio por dicha negligencia. ${ }^{351}$ Pedro López de Quinto aparece registrado en el libro de la cofradía de San Pedro Mártir de Zaragoza como cofrade y familiar del Santo Oficio en el período comprendido entre 1616 y $1635 .{ }^{352}$ Fue precisamente su adscripción a la Inquisición la que en octubre del año 1623 provocó un incidente a propósito de la consulta de la matrícula de los insaculados en los oficios del reino. En aquella ocasión, los inquisidores solicitaron del secretario de la Diputación y familiar del Santo Oficio la consulta externa de la matrícula de insaculados correspondiente al año 1536. Se tuvo que debatir en el seno de la Diputación tan atípica petición, por cuanto estaba prohibido (teóricamente) sacar documentos del archivo del reino fuera del palacio. Finalmente se permitió la consulta en las propias salas de la escribanía de la Diputación. ${ }^{353}$

No obstante, en las Cortes de 1626 se daba facultad a Pedro López de Quinto para que dispusiese de su oficio de secretario, alcaide y escribano «para que por testamento o por qualquiere otro género de contracto en vida o en muerte, pueda disponer de los dichos sus oficios de alcayde, secretario y escrivano principal de la Diputación, respectivamente en

349 En 1569 el nombre de Miguel López de Quinto aparece en la matrícula de insaculados para los oficios del reino como escribano de la Diputación: M. Pascual de Quinto (1916), p. 828. Savall y Penén (1866), vol. 1, p. 420. Los diputados nombraron en 1575 al escribano principal de la Diputación Miguel López para la guardia y custodia de todos los libros impresos por la Diputación.

350 Registro de actos comunes de 1599, A.D.P.Z., ms. 286, f. 114r-115v.

351 Registro de actos comunes del año 1614, A.D.P.Z., ms. 334, f. 260v-263r.

352 José Enrique Pasamar Lázaro (1997), p. 68.

353 Lorenzo Ibáñez de Aoiz, Ceremonial..., B.N.E., ms. 2922, f. 234v-236r. 
quien bien visto le fuere, pues la tal nominación y disposición sea en persona o personas beneméritas a satisfacción y contento de los diputados que son y por tiempo serán del presente Reyno». ${ }^{354}$

En dicha disposición ya se indicaba que Pedro López pertenecía a una familia asentada en los órganos administrativos de la institución aragonesa: «Por quanto Pedro López de Quinto ha muchos años que sirve los oficios de alcayde, secretario y escrivano principal de la Diputación deste Reyno, con mucha satisfacción de los diputados dél, a más de que también por muchos años respectivamente los tuvieron y sirvieron sus padre y agüelo». 355

En mayo de 1634 renunció a su cargo de escribano principal de la Diputación y fue sustituido inmediatamente por Martín Lamberto Íniguez. ${ }^{356}$

Jerónimo de Naya (1628?-1645)

Como consta en el Ceremonial de Ibáñez de Aoiz, "Pedro López de Quinto dispuso de sus officios en Pedro López su hijo, el qual concierto los dio a Martín Lamberto Yñiguez, ciudadano de esta ciudad y jurado en cap y çalmedina de ella y por su muerte en 20 de mayo del año 1640 hallándose diputado de este Reyno, Gerónymo de Naya, coadjutor ordinario del officio de maestre Racional, por su Magestad ministro del Santo Officio y ciudadano de esta ciudad, los señores diputados sus compañeros le hicieron merced de dichos oficios como consta por el Registro de actos comunes de la Diputación.».357

Notario sustituto, secretario, escribano y archivero del reino, Jerónimo de Naya constituye una de las piezas esenciales en el proceso administrativo y documental de la institución en los años centrales del siglo XVII. Como notario sustituto de la Diputación, aparece en 1621 subiendo al archivo con los diputados «sus señorías, presente yo, Herónimo de Naya, notario substituto de la Diputación y testigos infraescriptos, deliberaron subir al archiu de dicho Reyno y dél bolver los registros de actos comunes

354 Savall y Penén (1866), vol. 2, p. 386.

355 Ídem.

356 Registro de actos comunes del año 1634, A.D.P.Z., ms. 407, f. 250r-251v.

357 Lorenzo Ibáñez de Aoiz, Ceremonial..., B.N.E., ms. 2922, f. 114r-115r. 
infraescriptos». ${ }^{358}$ En noviembre de 1640 es el responsable de la librería y armería del reino y, como tal, entrega a 15 de noviembre «veynte y cinco cuerpos de libros intitulados de Leonardos y veynte y cinco volumenes de otros libros intitulados de San Juan de la Peña» al cronista Juan Francisco Andrés de Uztarroz. ${ }^{359}$ En mayo de 1645 simultanea los cargos con el de diputado y alcaide, alcanzando así la cúspide en el cursus honorum de la institución. ${ }^{360}$ De hecho, la vinculación de Naya al concepto de guardián y custodio aparece documentada en mayo de 1645, cuando solicita poder vivir en la propia casa de la Diputación. ${ }^{361}$ En 1654 Naya sigue siendo el conservador de la armería del reino. ${ }^{362}$ Todavía en 1661 se documenta la labor de Naya, esta vez como secretario de la Diputación, entregando unos registros a los diputados. ${ }^{363}$ Finalmente, como persona altamente experimentada en todos los procesos administrativos y documentales desarrollados en el seno de la Diputación durante más de 30 años, escribió en abril de 1664 un memorial altamente interesante. De hecho, en él venía a denunciar a varios notarios que no habían cumplido con el fuero referido a la entrega y remisión de registros finalizados al secretario para remitirlos al archivo del reino. ${ }^{364}$

358 Registro de actos comunes del año 1621, A.D.P.Z., ms. 361, f. 73r-73v.

359 Registro de actos comunes del año 1640, A.D.P.Z., ms. 434, f. 92r.

360 Registro de actos comunes del año 1644, A.D.P.Z., ms. 449, f. 164v: «Dicho señor Diputado Gerónimo de Naya, dixo y allegó es secretario del Reyno y escribano principal y archivero y que es notario real y que como a tal secretario le pertenecen las cabrebaciones de los censales que dicho reyno haze [y no] al notario extracto lo qual consta y pareze por los actos del presente Reyno y mediante sentencia dada en el año mil quinientos noventa y ocho inserta en el registro de actos comunes de la diputación de dicho año [...] le toca a él y no al notario".

361 Ídem: «El dicho señor Gerónimo de Naya, dixo y allegó que su señoría es alcaide de las cassas de la diputación y que si quisiese estar y vivir en ellas o su teniente, ha de tener en aquellas habitación suficiente y que lo impide Juan de Gracia, que vive en ellas, teniendo ocupado lo mejor, y a más dello, los señores diputados del año pasado le hizieron gracia y merced de darle la futura sucesión de vivir en dichas casas de la diputación para su muger y hijos y tambíen de retocar y limpiar los quadros de la diputación como parece por acto testificado a veinte y siete del mes de febero [sic] del año mil seiscientos quarenta y quatro; lo qual (salva parescer) los dichos señores diputados no lo podían hazer y mucho menos sin razones si algunas tenía, porque lo sobredicho hazer no se debía; lo qual no hizieron. Por lo qual, suplicó a sus señorías revocaran dicha futura sucesión».

362 Registro de actos comunes del año 1654, A.D.P.Z., ms. 483, f. 362v.

363 Registro de actos comunes del año 1660, A.D.P.Z., ms. 506, f. 497v.

364 Registro de actos comunes del año 1663, A.D.P.Z., ms. 517, f. 573r. 


\section{Melchor Martínez Novella (1651-1666?)}

El sustituto de Jerónimo de Naya en la regencia del archivo del reino fue notario real, nombrado archivero en junio de 1651 por los diputados, de quien «recibe las llaves del archiu de los papeles de la corte del Señor Justicia de Aragón». ${ }^{365}$ En febrero de 1656 se le pagan las cincuenta libras jaquesas por su oficio de «archibero que soy del archibo de los processos de la Corte de Señor Justicia de Aragón y de la general Governación del dicho Reyno». 366

Juan Miguel Pérez de Hesco (1670-?)

Aparece documentado como secretario y archivero de la Diputación en mayo de $1670 .{ }^{367}$

Francisco Valero Alcaine (1671-1693)

Este infanzón domiciliado en Zaragoza ejerció el cargo de archivero de la Diputación del reino desde 1671, siendo sustituido por su hijo Pedro Valero en noviembre de $1693 .{ }^{368}$

\section{Pedro Valero Alcaine (1693-1705)}

Hijo de Francisco Valero, es el último archivero de la Diputación del reino antes de su extinción. En noviembre de 1699 aparece citado en una capitulación de la Diputación con Lorenzo Calvo para la organización del

365 Registro de actos comunes del año 1651, A.D.P.Z., ms. 471, f. 32v.

366 Registro de ápocas, comisiones y consultas año de 1655, A.D.P.Z., ms. 487.

367 Registro de actos comunes del año 1669, A.D.P.Z., ms. 533, f. 339: «pareció Juan Miguel Pérez de Hesco, secretario y archivero della, el qual dixo y confessó que el muy illustre señor don Francisco Sanz de Cortes, marqués de Villaverde, arrendador y administrador de las generalidades, ha puesto en el archivo mil y [en blanco] cuerpos de libros de los anales de Çurita de los tomos quarto y sexto y que aquéllos están archivados».

368 Registro de actos comunes del año 1693, A.D.P.Z., ms. 601, f. 112v-113r: «Eadem die Cesarauguste en consistorio y estando juntos en forma pública los illustrísimos señores [...] diputados: atendido a los muchos años que ha servido el ya difunto Francisco Alcayne a este illustre Reyno en el oficio de archibero de los papeles de este illustrísimo Reyno y que aquél, por los fueros y actos de corte de 1686 se le hizo gracia para disponer del dicho su oficio. Por tanto, confiando de la legalidad, suficiencia y cristiandad de Pedro Balero Alcayne, hijo de dicho Francisco Alcayne pasaron a hazer e hizieron sus señorías gracia y merced del dicho oficio al dicho Pedro Balero Alcayne y le nombraron en archibero de dichos papeles y le adjudicaron todos los salarios, honores y emolumentos». 
archivo del Justicia, aunque finalmente el archivero tuvo que hacerse cargo de estas tareas. ${ }^{369}$

\subsubsection{Los archiveros bajo la administración borbónica}

A lo largo del siglo XVIII continuaron los nombramientos de archiveros y oficiales responsables del fondo documental de la Diputación del reino de Aragón, que permaneció en la misma sede; de modo que las series procedentes de la actividad desarrollada por esta institución quedaron teóricamente a salvo del posible descuido administrativo propiciado por su abolición con la Nueva Planta borbónica. Este hecho se debe enmarcar en la intensa revitalización de la organización archivística propiciada por dos fenómenos comunes a toda la Monarquía. Por una parte, la necesidad de disponer de forma organizada de la documentación para su uso con una finalidad fiscal y administrativa. Y por otra parte, el afán de organizar las escrituras para dar satisfacción a la creciente investigación erudita que acudía a los archivos en busca de información para sus trabajos. ${ }^{370}$ El primer archivero en esta nueva etapa fue don Martín Maza de Lizana, quien había desempeñado el cargo de secretario interino de la Junta del Real Erario, desde donde accedió al de responsable de la custodia de la documentación procedente de la Diputación del reino durante el período comprendido entre 1718 y 1748, fecha de su fallecimiento. Siguió a este archivero en el cargo don Pedro Felipe de Lezaun, ya que la solicitud entregada por el hijo de Martín Maza de Lizana, don Martín Maza y Villalba, había sido desestimada. ${ }^{371}$ Es preciso indicar que el hijo de don Pedro Felipe de Lezaun desarrolló gran parte de su gran investigación documental en el archivo que regentaba su padre. De hecho, Tomás Fermín de Lezaun elaboró un gran número de obras, compendios, resúmenes y extractos a partir de la rica

369 A.C.A., Manuscrito misceláneo n. 220, f. 161: «Assí mesmo, avemos visto que por no haver dado cumplimiento Don Lorenzo Calbo a la capitulación que otorgó sobre la composición de los procesos de la Real Audiencia y de la Corte, han determinado los señores diputados de el consistorio passado el removerlo, capitulando de nuebo con el archivero del Reyno, Pedro Valero Arcayne, que continúe en la composición de los procesos de ambas tribunales en conformidad de los pactos que contiene la capitulación que parece en el registro de los actos comunes del año pasado $[\ldots]$ ».

370 Informe de Santiago Agustín Riol al marqués de Grimaldo sobre los papeles de la Monarquía (30 de agosto de 1726), B.N.E., ms. 9995.

371 Diego Navarro Bonilla (1996). 
información custodiada en el archivo de la antigua Diputación del reino. ${ }^{372}$ Junto a Lezaun desarrolló su actividad el archivero José de Yoldi, responsable del más extenso inventario del archivo del reino durante el siglo XVIII. Más adelante se hallaría al frente del depósito Felipe Fernández de Arias, ${ }^{373}$ a quien habría de seguir Manuel Antonio de Terreros ${ }^{374}$ hasta llegar al último archivero, probablemente su hijo don Santiago Terreros, tal y como se desprende de la Guía de Borau de Latrás. ${ }^{375}$ Este funcionario fue uno de los artífices del traslado de los fondos documentales albergados en el archivo del reino tras la destrucción del palacio de la Diputación en 1809, encargándose de coordinar las tareas de salvaguardia de los documentos. ${ }^{376}$

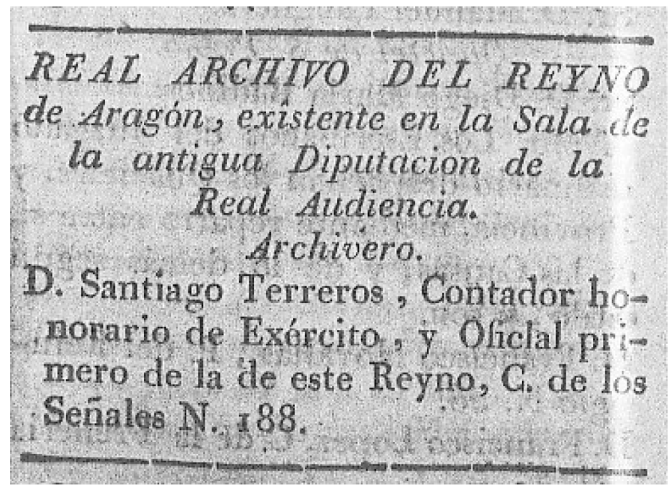

Miguel Borau de Latrás, Guía de Zaragoza..., Zaragoza, Imp. de Miedes, 1806.

\subsection{Cronistas y archiveros o la regencia del archivo como culminación del cursus honorum}

La vinculación del cargo de cronista o relator oficial con el universo del testimonio escrito es un hecho que en Castilla cobra especial fuerza

372 Miguel Gómez Uriel (1884-1886), s.v. Lezaun. Sobre los datos genealógicos de los Lezaun, véase el trabajo de Miguel Ángel Castán y Alegre (1998).

373 A.D.P.Z., leg. 755-11, publicado en Navarro Bonilla (1997).

374 Certificación dada por don Manuel Antonio de Terreros, archivero de la antigua Diputación, a 2 de agosto de 1798. A.H.P.H., Casa Bardají, leg. 27-1-5.

375 Miguel Borau de Latrás (1806).

376 Diego Navarro Bonilla (1999a). 
durante los siglos XIV y siguientes. Como indica Elisa Ruiz, la narración oficial de los hechos comienza a ser asignada a un representante de los denominados «letrados al servicio del Rey». ${ }^{377}$ A fin de cuentas, comienza a vislumbrarse una evidencia que tomará especial relieve durante el siglo XVI: la construcción historiográfica oficial descansa sobre el testimonio escrito. Lograr el efecto pretendido con la historia oficial descansa sobre el orden y la composición de las escrituras. Es decir, mantener organizados y accesibles los incipientes y ya voluminosos depósitos documentales proporciona garantías de operatividad no sólo para el normal funcionamiento cotidiano de la maquinaria burocrática y administrativa, sino también para elaborar las denominadas «operaciones de preservación del poder y estrategias de la memoria». ${ }^{378}$ Se trata, en definitiva, de fundamentar la historia de una colectividad mediante el recurso activo a la documentación oficial.

Para el caso aragonés, Jerónimo Zurita inaugura la nómina de cronistas oficiales y paradigmático será su caso a la hora de reivindicar la consulta directa de los documentos para construir la historia. Su método es continuamente elogiado, por cuanto desciende hasta el documento original para argumentar su investigación, dando lugar a un estilo centrado en el testimonio escrito. Un estilo que en la segunda mitad del siglo XVII no se dudó en criticar veladamente, al calificarse su redacción de anticuada y poco ágil desde la perspectiva del historiador de 1684: «como no es razón entre personas que professan letras el ceñirse a razones generales, el estilo de Zurita fue bueno para ahora 150 años, pero oy pide ser más lacónico y cortesano, porque assí le acostumbran todos los modernos». ${ }^{379}$

En este sentido, fruto de la consideración y valor concedidos al testimonio escrito en el que se vieron inmersos los cronistas aragoneses y gracias al cual desarrollaron su obra, fue el deseo manifestado por alguno de ellos de culminar su vinculación con la documentación con un cargo de responsabilidad que proyectase su quehacer cotidiano sobre la adecuada organización y conservación de las escrituras. La proximidad de los his-

377 Elisa Ruiz (1999).

378 Antonio Castillo (1998).

379 Carta del conde de la Alcudia al cronista Diego Dormer el día 6 de diciembre de 1684. R.A.H., ms. 9/548, f. 443. 
toriógrafos aragoneses, reputados organizadores y asiduos lectores de las antiguas escrituras del reino, al archivo de la Diputación pasaba primeramente por su familiaridad con la organización y disposición de las series custodiadas en sus ochenta y ocho armarios y el desarrollo de buena parte de su trabajo en un aposento, como hemos visto, muy próximo a este depósito documental. Pero también esta relación y la frecuencia de las consultas posibilitó la adquisición de una experiencia archivística, que no se dudó en aportar como mérito profesional a la hora de solicitar puestos más próximos a los responsables archiveros y regentes de las escrituras administrativas. De este modo, el archivo del reino de Aragón se convirtió para los cronistas en aula de aprendizaje e instrucción en el método y orden de las escrituras emanadas de una institución en el ejercicio de sus funciones.

Como indica Fernando Bouza, «en el siglo XVII, poco a poco, el archivo se fue convirtiendo en el símbolo del paso a la posteridad también para los autores, una especie de última meta de los hombres de letras que habían vivido por la escritura, de la que el archivo es su consumación, a veces en grado mayor que la biblioteca», 380 si bien es cierto que en épocas anteriores también se dieron casos de archiveros con vocación de historiadores $^{381}$ (la simbiosis fructífera entre la organización de las escrituras y la elaboración de crónicas e historias ya fue característica de don Pere Miquel Carbonell, archivero real en Barcelona desde 1476). ${ }^{382}$ El proceso ahora seguido fue distinto: de la crónica al archivo.

Junto a esta predilección archivística, casos hubo en que el método y la organización bibliográfica también fueron ámbito de dedicación del cronista, como Andrés de Uztarroz, quien elaboró un curioso Diseño de la insigne y copiosa biblioteca de Francisco Filhol, presbítero, impreso en $1644 .^{383}$ Pero mucho más intensa fue su actividad de consulta y entendimiento de la organización de los testimonios escritos custodiados en el archivo. A tal efecto, el insigne cronista obtuvo permiso de los diputados

380 F. Bouza (1998), p. 46.

381 Peter Russell (1996), pp. 67-83.

382 Agustí Alcoberro (1993).

383 Publicada por Ricardo del Arco y Garay, La erudición española en el siglo XVII y el cronista Andrés de Uztarroz, Madrid, Instituto «Jerónimo Zurita», 1950, vol. 1, pp. 337-338. 
para organizar el archivo del reino, como consta en el memorial impreso del cronista Dormer: «El doctor don Juan Francisco Andrés, cronista oficial desde 1647 a 1653 ordenó el Archivo del Reyno, y compuso varias obras, viviendo sólos quatro años en el oficio, por quitarle la vida el continuo afán en inquirir y juntar noticias y es sin duda que con su tesón y porfía, huviera vencido el olvido de tanto tiempo, ayudado del favor y medios y de 300 libras que tuvo de salario por fuero particular de 1646». ${ }_{384}$

La documentación conservada en la Real Academia de la Historia ilustra con más detalle el ensayo del doctor Andrés de Uztarroz por organizar las escrituras del archivo del reino. En un memorial fechado en 26 de octubre de aquel año 1646, el secretario del brazo de universidades certificaba que las Cortes lo habían nombrado cronista del reino, pero también para «componer los papeles del archibo, poniéndolos en orden con el inventario, claridad y noticia que conbiene y se le den cien libras jaquesas de salario en cada un año de las generalidades del Reyno». ${ }^{385}$ Con mayor solemnidad, el permiso de Uztarroz para organizar la memoria escrita custodiada en el archivo del reino se formalizó efectivamente en las disposiciones forales de 1646, en las que se indica cómo «Su Magestad de voluntad de la Corte y quatro braços della, nombra al dotor Iuan Francisco Andrés, por coronista deste Reino, para que desde luego trabaje continuando las Historias dél, con obligación que haya de componer los papeles del archivo del Reino, con asistencia de uno o más diputados, poniéndolos en orden, haziendo una rúbrica de todos ellos, para que se tenga noticia de los papeles de dicho Reino y se hallen con mayor facilidad». 386

Otro caso similar al de Uztarroz es el del arcediano Dormer, que aspira a culminar una intensa trayectoria profesional de hombre de letras y papeles en un archivo (en este caso el del Consejo de Aragón). Su tarea como historiador es rica en matices e informaciones que presentan al arcediano como dotado de gran ingenio, erudición y viveza intelectual. Sus continuas visitas a archivos y librerías son registradas en un enorme volumen documental todavía inédito. Sin embargo, queremos en estas líneas subrayar especialmente la conexión entre su tarea historiográfica y la visi-

384 B.N.E., ms. 8380, f. 283.

385 R.A.H., ms. 9/548, f. 316.

386 Savall y Penén (1866), vol. 2, p. 399: «Del coronista del Reino». 
ta a los archivos de su tiempo que se descubre en la abundante documentación generada por Dormer como consecuencia de las difíciles relaciones con el equipo de gobierno de la Diputación; lo cual posibilitó también el conocimiento de algunos datos de sumo interés sobre el archivo del reino, como depósito próximo y principal al que acudir en busca de noticias para continuar el edificio historiográfico encargado por los propios diputados.

En 1681 escribía Dormer a los diputados «Que su oficio de coronista se halla formado en este Reyno por las Cortes generales del año 1547 y que para cumplir con la obligación de él, a más de las noticias particulares de los registros de la Diputación, que tiene resumidos, es preciso por la dilatación de la Monarquía, el inquirir las de los archivos principales de Simancas y Barcelona y los de la Cancellería del Consejo Supremo de Aragón, adonde paran todos los papeles de estado, paz y guerra, tocantes a los reynados». 387

Quejábase el arcediano de las ventajas disfrutadas por otros cronistas antecesores, a lo que los diputados contestaban que la costumbre había sido facilitar el trabajo del cronista "porque el Reyno siempre ha estilado el franquear a sus coronistas quantos papeles le han pedido». La precipitada salida de la tan admirada fortaleza de Simancas por orden expresa de los diputados, una vez que hubieron considerado la imposibilidad de una prolongada ayuda económica en 1681, fue uno de los detonantes de su descontento. Todo el proceso de quejas elevadas ante los diputados por parte de Dormer se originó en las dificultades que a juicio del arcediano se interpusieron y que consecuentemente influyeron en el resultado final de sus crónicas. Pero difícilmente podían los diputados aragoneses aceptar las pretensiones del canónigo Dormer, que se atrevió incluso a cuestionar la validez y cantidad de los registros y escrituras conservados en el depósito del reino. Argumentar la necesidad de organizar y dotar económicamente un viaje por la geografía archivística en busca de informaciones basándose en la falta de materiales en la propia sede del reino fue considerado una ofensa a la institución, a su memoria y, por extensión, a la propia personificación del archivo del reino.

387 Memorial de Dormer a los diputados solicitando ayudas pecuniarias para sus viajes a los archivos españoles. R.A.H., Colección Salazar, ms. 9/548, f. 436r. 
El famoso memorial enviado por Dormer a los diputados, por el que renunciaba voluntariamente a su cargo de cronista, fue oportunamente contestado por los diputados en agosto de 1703. La réplica razonada elaborada por los diputados para contrarrestar el menosprecio vertido sobre el archivo constituía una clara e inequívoca toma de conciencia documental colectiva sobre el valor de la memoria escrita del reino conservada en el archivo:

"Attendido assí mismo que no ay noticias para la continuación de los Anales en el Archibo, \&c»

\section{Respuesta}

No se contenta el arzediano con tener quexosos a los diputados, sino que también quiere que lo esté el Archibo del Reyno, diciendo que no ay en él noticias para la continuación de los Anales; y pareze que no puede ser assí, sino que antes bien recobrando los papeles que son suyos, ha de haver noticias cavales de todo el Reynado del señor Emperador Carlos Quinto; y es claro argumento de esto el tomo de Anales que imprimió el arzediano, pues en él no se ve otra cosa que los registros del Archibo del Reyno vaciados enteramente. Y la rebelión de los servicios echos a Su Majestad estaba repetidamente impresa en diferentes libros y en el cargo de censos que el Reyno paga por los servicios hechos, que los fueros y actos pregonan, con que fue obra de poco trabajo el juntarlos y volverlos a publicar. [...]. ${ }^{388}$

Si finalizar en el archivo es considerado como el punto culminante de una vida consagrada a la exhumación documental, a la organización, revisión, copia y consulta del documento de archivo, no es menor la estima y el valor asociado a la simbología del poder que los diputados proyectaron sobre el archivo del reino. A lo largo de estas líneas hemos comprobado los testimonios que subrayan la necesidad de mantener organizadas las escrituras como memoria de la colectividad garante de la esencia política y jurídica de la colectividad aragonesa. Atacar o menospreciar el archivo es una ofensa dirigida contra todo el consistorio aragonés, en el mismo momento en que la evocación del pasado necesariamente transita por el recurso a la documentación como instrumento de constancia.

Finalmente, y como resultado del honor que significaba culminar el cursus honorum de un hombre de erudición en un archivo, Diego José Dormer elaboró un interesante memorial en el que venía a solicitar una

388 R.A.H., Colección Nasarre, ms. 11/7946, f. 32. Zaragoza, 30 de agosto de 1703. 
plaza de archivero en el Consejo de Aragón. Su experiencia en el manejo continuado de las escrituras del archivo del reino, la pericia paleográfica, además de la reputación de su cargo como cronista del reino aragonés, fueron argumentos que el cronista esgrimió para conseguir la plaza de archivero. Incluso ponía su destreza en la gestión documental en su lista de méritos para proponer mejoras, apelar al principio de procedencia documental y, sobre todo, argumentar y convencer de que la plaza no supondría un gravamen a las arcas del monarca. ${ }^{389}$

389 Publicado en Navarro Bonilla (1999c). 



\section{LA ORGANIZACIÓN DE LOS DOCUMENTOS}

\section{1. ¿Por qué se organizan los documentos?}

La generación de documentos por parte de los órganos administrativos de una institución en virtud de sus funciones y sus competencias, de acuerdo con un procedimiento administrativo más o menos normalizado, es un acto necesario para que esa institución tramite sus asuntos, adopte sus decisiones, defienda sus acuerdos y deje constancia de sus acciones. Se trata de una actividad espontánea de las instituciones durante el cumplimiento de los fines que les son propios, que tiene como resultados la creación de un fondo documental de carácter único, involuntario, orgánico y seriado. Sin embargo, la utilidad para la gestión administrativa y el valor de testimonio de dicho acervo de documentos dependen del programa de control que se implante. Es decir, el conjunto de operaciones destinadas a la organización de los documentos que componen el fondo de archivo resulta imprescindible para dotar al archivo de la eficacia operativa que se le requiere.

La literatura archivística define con precisión las actividades que conforman un sistema de organización documental. En ellas se han de diferenciar aquéllas de naturaleza intelectual y física. Todas ellas conducen a un objetivo común que se centra en la elaboración de instrumentos documentales que facilitan el acceso al ingente cúmulo informativo contenido en libros y registros. En definitiva, se trata de procesar datos para informar y hacer accesibles las series documentales. Este proceso se concreta en la construcción de medios documentales de acceso a la información en función de un nivel descriptivo más o menos exhaustivo. 
La descripción de la documentación de archivo ha sido una constante histórica y paralela a la misma formación y consolidación de los archivos del Antiguo Régimen. ${ }^{390}$ Consejos, municipios, cofradías, parroquias, casas nobiliarias, ${ }^{391}$ desarrollaron mecanismos más o menos eficaces para describir su producción documental, con el propósito de dejar constancia del patrimonio escrito, pero también con una orientación eminentemente práctica: conocer la ubicación de los documentos y acceder a su contenido a través de un extracto. Por ello, surgen instrumentos de registro escrito de las escrituras según diferentes niveles de detalle, más o menos completos en sí mismos, como inventarios, índices y luceros de todo tipo, que se erigen en instrumentos básicos en cualquier sistema de organización documental y que invaden todo el espectro posible de instituciones de esa época. La reciente publicación de Jaime Riera sobre los memoriales e inventarios originales del archivo real de Barcelona incide en la necesidad de considerar esta tipología documental como una de las más interesantes para analizar las tareas de descripción de los fondos de un archivo. ${ }^{392}$ Esta tendencia alcanza su culminación durante el siglo XVIII, período en el que se asiste a todo un proceso generalizado de descripción de las antiguas escrituras que reposaban en archivos y bibliotecas, de definitiva consideración del testimonio escrito como fuente de primer orden para la erudición historiográfica y de aprecio material de determinados soportes de escritura. En España, los trabajos archivísticos de Cristóbal Rodríguez, Juan Antonio Fernández o Rafael de Floranes constituyen una muestra, ilustre sin duda, de una dinámica que lleva a conocer el contenido de multitud de archivos municipales, parroquiales, generales, etc., con una intención de servicio documental a la organización fiscal y administrativa y también a la creciente investigación histórica. ${ }^{393}$ Por ello, el archiconocido

390 F. de B. Aguinagalde Olaizola (1988). Paul Delsalle (1998), pp. 163-177. Otros trabajos repasan la evaluación histórica de la descripción documental en los archivos municipales: Mariano García Ruipérez (1999) y Mariano García Ruipérez y Carmen Fernández Hidalgo (1999).

391 Hay numerosos ejemplos de cómo los archivos nobiliarios mantuvieron la memoria de sus fondos a través de la creación de instrumentos de descripción documental. Merece destacarse el trabajo de María José Casaus Ballester (1997), donde se identifican 6 índices y 47 inventarios o relaciones de documentos fechados entre 1716 y 1875 con que cuenta el archivo ducal de Híjar. Véase también A. Sánchez González (1990).

392 Jaime Riera (1999).

393 Cristóbal Rodríguez (1992-1993), «Forma i Modo de componer i coordinar qualesquier archivos públicos, generales y particulares (1730)». 
informe de Riol sobre la situación y evolución de los archivos de la monarquía hispánica vino a confirmar a mediados del siglo XVIII la práctica archivística española reforzando aún más si cabe el papel del archivo y su íntima relación con el ejercicio del poder. ${ }^{394}$

En definitiva, se describe para controlar la documentación que se posee y para garantizar un acceso rápido a ella con el fin de afianzar el valor o, mejor dicho, los valores que se derivan de la memoria escrita. ${ }^{395}$

Centrándonos en el caso de la Diputación del reino de Aragón, su archivo fue objeto de las más variadas tareas descriptivas a lo largo de su dilatada existencia, ya que constituye una pieza esencial en el damero administrativo y organizativo global de la Diputación. Al archivo van a parar escrituras tramitadas, en él se organizan y de él se extraen y resumen las informaciones documentadas contenidas en las series archivísticas. Por tanto, el esquema documental general se vislumbra con notable precisión, al desarrollarse operaciones de génesis documental, remisión y extracción, control y organización de la documentación y consulta de ésta. El período culminante de su organización fue el siglo XVII, cuando la necesidad de revisar la historia aragonesa y de justificar las nuevas tendencias políticas en relación con la Monarquía tras la rebelión de 1591 obligan a la exhumación de numerosas fuentes documentales. El resultado de esta masiva consulta documental, aparte de la lógica derivada de las normales y cotidianas tareas administrativas, es una imperiosa necesidad de tener organizados los documentos con el fin de controlar su contenido y su disposición y acceder fácilmente a su ubicación.

No obstante, la clasificación, ordenación y descripción de los documentos del archivo no se paralizaron a finales del siglo XVII. De hecho, en 1699 se tiene noticia colateral de una descripción del archivo encargada a Diego Villagrana y otros, "para poner en buen orden los papeles del archivo». ${ }^{396}$ A pesar de que el registro de actos comunes no se encuentra entre los fondos de la actual Diputación Provincial, se puede comprender que

394 Informe de Santiago Agustín Riol al marqués de Grimaldo sobre los papeles de la Monarquía (30 de agosto de 1726), B.N.E., ms. 9995.

395 Antonio Castillo (1997), pp. 251-263.

396 La noticia se encuentra en el índice y resumen del contenido de los registros de actos comunes, A.D.P.Z., ms. 622. 
las tareas de organización y descripción archivística se mantuvieron casi hasta el final del período foral institucional, lo que demuestra el valor y la utilidad del testimonio escrito. Tareas que continuaron también a lo largo del siglo XVIII, momento en que se crearon algunos de los más importantes instrumentos de descripción.

Naturalmente, el sistema organizativo general desarrollado en el archivo del reino responde a la necesidad que el poder tiene de recurrir a la memoria escrita y al testimonio documental para ejercer sus actividades cotidianas. Las escrituras organizadas se constituyen así en instrumento al servicio del poder, bien para ejercer sus competencias de gobierno, bien para favorecer la gestión administrativa interna de la institución o bien para fundamentar derechos y privilegios. Las manifestaciones más preclaras de este proceso de instrumentalización del testimonio escrito por parte de los diputados aragoneses se analizan en el capítulo centrado en el análisis de la relación entre el ejercicio del poder y la organización de su propia génesis documental. Por contra, en este capítulo nos ocuparemos de las formas técnicas en que «el orden y arreglo de las escrituras» se concretó en el archivo del reino, dando lugar a un continuado método descriptivo y organizativo cuyos resultados se mostrarían en numerosos «índices, inventarios, luceros, relaciones, memoriales» y cuantas tipologías mostrasen la realidad del archivo, su evolución, contenido y funcionamiento.

La conciencia documental adquirida por los sucesivos equipos de gobierno de la Diputación del reino fructificó en una notable actividad organizativa documental. Ésta se encuentra perfectamente delimitada en una serie de actuaciones archivísticas desarrolladas para tener un control operativo de la producción documental custodiada en el archivo, así como un conjunto de instrumentos descriptivos para facilitar un más eficaz acceso a la información documentada. En este sentido, fueron numerosos los inventarios de las series del archivo, así como los índices o extractos de las noticias más sobresalientes contenidas en los registros de actos comunes de la Diputación, verdadero libro registro de la actividad cotidiana del consistorio aragonés.

De hecho, el asentamiento de esta conciencia propició la puesta en práctica de diferentes estrategias de preservación de la memoria escrita, pilar básico de la identidad del reino, así como de su administración, su gobierno y su historiografía. Disipar el olvido mediante la escritura orga- 
nizada y acceder a ella mediante operaciones documentales de resumen y condensación informativa constituyeron buena parte de estas maniobras documentales.

\subsection{Instrumentos de descripción documental}

En numerosas ocasiones, la evolución histórica del archivo del reino y su contenido han sido aspectos indicados por escrito en documentos relacionados más o menos directamente con la intención de dar a conocer el depósito documental. Describir el archivo permite conocerlo, extraer las informaciones esenciales contenidas en los voluminosos y extensos registros facilita por medio del resumen informativo una operatividad documental más inmediata. El acceso a la información que registros, procesos y escrituras diversas proporcionan a través del archivo, se efectúa a través de instrumentos descriptivos concretos, ilustrando así una notable actividad archivística y documental en el seno de la Diputación del reino durante la Edad Moderna. Estos instrumentos se elaboran siguiendo unos parámetros bien definidos de exhaustividad y nivel descriptivo.

Así, se cuenta con descripciones generales del estado del archivo y de las series que lo integran, a modo de guías generales, incluidas en los memoriales, ideas y relaciones de los archiveros y cronistas del reino en su condición de usuarios habituales del archivo y en algunas ocasiones «componedores» especializados de sus escrituras y cajones. En este mismo nivel, nos suministran información complementaria sobre el archivo documentos tales como instrucciones sobre el modo de consultar algunas tipologías documentales, expedientes de obras y consultas elevadas a la corte del Justicia sobre la necesidad de destinar diversas cantidades a las tareas de preservación y limpieza documental. En un segundo nivel descriptivo se hallan los inventarios de series documentales concretas, que constituyen una pieza fundamental en la organización de las escrituras del reino, donde se suele indicar el contenido mediante un numerus currens, un extracto de la tipología documental y el año al que corresponde. Junto a ellos, los diputados, conscientes del valor que ofrece para la gestión administrativa la correcta conservación y acceso a los actos jurídicos documentados, encargan la confección de índices y extractos de las noticias recogidas en los registros de actos comunes de la Diputación. Estos índices 
representan el más acabado medio de acceso a esta auténtica memoria diaria de la actividad del consistorio aragonés. Y todo ello a través del análisis documental de la información que contienen, cuyo producto se sintetiza en forma de palabras clave ordenadas alfabéticamente y de resúmenes de su contenido.

Finalmente, la documentación referida al archivo y su contenido subyace en otras tipologías inmersas en el proceso administrativo, como las hojas de remisión de series tramitadas enviadas al archivo, registros de entrada y salida de escrituras, consultas de la documentación en el propio archivo y fuera de él, así como las certificaciones expedidas por el archivero. De todos estos instrumentos descriptivos del archivo como espacio físico perfectamente delimitado dentro de las salas y habitaciones del palacio de la Diputación y de su contenido se hará oportuna referencia a continuación. La consecuencia documental de todo este esforzado proceso se concreta en la habilitación de todo un armario del archivo del reino para custodiar el importante número de instrumentos de descripción, y que dará lugar a una serie identificada bajo el título del armario número 1: índices y rúbricas. ${ }^{397}$

\subsubsection{Inventarios generales de series documentales}

Los inventarios y listados generales de las series documentales existentes en el archivo de la Diputación del reino de Aragón anotan de manera más precisa que las relaciones globales del archivo los números de los cajones que componen la sala del archivo y, a continuación, la relación de su contenido. Constituyen a su vez una serie completa descriptiva del fondo de la Diputación, ocupando el armario número 1 de los 88 que componían la sala del archivo bajo el rótulo índices y rúbricas. Se cuenta con los siguientes:

1. Registro de documentos existentes en el archivo de la Diputación del reino de Aragón. Documentación de los siglos XV a XVII.

2. Índice de documentos del archivo del reino. Siglos XV-XVII.

3. Registro de documentos existentes en el archivo de la Diputación del reino de Aragón. 1300-1600.

397 Diego Navarro Bonilla (2000a). 
4. Rúbrica de los registros, libros y papeles que hay en el archivo del reino de Aragón, empezada en 1660.

5. Tomás Fermín de Lezaun, «Noticia del índice y rúbricas del Archivo de la Diputación del Reyno».

6. José de Yoldi, «Índice de las escrituras del archivo del Reino de Aragón (1749-1750)».

7. F. José de Velasco, «Ymbentario de diferentes papeles y escrituras que se hallan en el archivo deste reino de Aragón copiado del libro cabreo u bezerro de dicho archivo desde el día 12 hasta el 17 de nobiembre del año de 1750».

Registro de documentos existentes en el archivo de la Diputación del reino de Aragón. Documentación de los siglos XV a XVII ${ }^{398}$

Por las indicaciones que se contienen en la cubierta de este inventario general — «Francisco Muñoz y Miguel, Almario 1, número 8»—, efectivamente formaba parte del armario primero, destinado a «índices y rúbricas». Constituye un registro de 212 folios con letra del siglo XVII. En el folio 1 se lee: «Se ha de atender lo primero al título del almario en que están, que son almario [...] que se intitula "Proceso de súplicas de la A y las siguientes letras"; almario 78, procesos de información y recepción de testigos de la A y sus siguientes; almario 79, procesos de viedas y civiles fraudes, execuciones y ocupaciones; almario 80 , procesos criminales de treguas y soluciones decisas».

Este manuscrito da noticia de tipos documentales de naturaleza procesal contenidos en los armarios del archivo del reino y generados en función de las competencias de la Diputación. Éstos se refieren a:

a) Procesos por insaculación: como tipología derivada de la actividad procesal en función de las competencias forales de la Diputación, los procesos son relativamente abundantes en el fondo de la Diputación. Para dirimir cualquier diferencia surgida en torno al concepto de insaculación y resolver las posibles alegaciones que un particular plantease por considerar injusto el resultado del procedimiento, se tramitaba el proceso insaculatorio. Este inventario de procesos sigue varios criterios de ordenación y presentación de la

398 A.D.P.Z., ms. 59. 
información. El primer criterio es la alusión explícita del tipo documental; el segundo, el número de ligamen; el tercero, el orden alfabético por inicial del nombre del incoador del proceso e indicación del año del proceso.

b) Procesos de súplicas, también ordenado alfabéticamente por inicial y año del proceso.

c) Procesos de denunciaciones, con idéntica ordenación.

d) Procesos de sumarias informaciones y recepción de testigos.

e) Procesos de vedas de panes y carnes, procesos civiles, procesos por fraudes y por ejecuciones y ocupaciones.

f) Procesos criminales, procesos de treguas y procesos de soluciones de sisas, cabrevaciones de censales, consultas y copias de procesos de la corte del Justicia de Aragón y zalmedina.

Índice de documentos del archivo del reino. Siglos XV-XVII ${ }^{399}$

No es un índice como tal, sino el fragmento de un inventario donde sólo se indican los procesos de infanzonías. Es posible que formase parte de un inventario mayor con todas las series. El inventario aparece ordenado por tipología documental (proceso de infanzonía), ligamen, años y escribanías. Escrito en el siglo XVIII, consta sólo de 6 folios.

Registro de documentos existentes en el archivo de la Diputación del reino de Aragón. 1300-1600400

Se trata de otro extenso inventario donde se localizan esencialmente las tipologías de naturaleza económica. Constituye un instrumento descriptivo con indicación del numerus currens dentro de cada tipología, un extracto, la cantidad del censal y el año. Al comienzo de cada tipología se destacan los centenarios, lo que induce a pensar en una utilidad de consulta cronológica; sin embargo, no se indica su localización dentro del archivo ni existe remisión al número de armario.

Entre las tipologías documentales que enumera el inventario se encuentran: censales, sentencias de censales, revendiciones de censales, vendicio-

399 A.D.P.Z., leg. 754-14.

400 A.D.P.Z., ms. 5. 
nes de censales, reconocimientos y cesiones de censales, luiciones de censales, cesiones de censales, donaciones de censales, consignaciones de censales en favor de otras personas, capitulaciones matrimoniales y firmas de dotes, testamentos, intimas y recuestas, sindicados, sustituciones (de personas que trabajan para los diputados o a quienes se ha otorgado un poder para cosas puntuales), loaciones de reyes (en Aragón, la confirmación o aprobación de una cosa), privilegios, procuras, definimiento de cuentas y reducciones de censales. También se indican otras tipologías mediante un encabezamiento pero sin indicación de contenido: libros de la administración del general, libros de encautes, libros de fogajes, registros de cartas misivas, registros de actos comunes, libros de asistencias de los diputados y bastardelos, libros de ápocas, provisiones y consultas, papeles del secretario Zurita, ápocas. Esta circunstancia permite conjeturar que dicho registro se elaboró con la intención de recoger únicamente la documentación económica y no el resto de tipologías custodiadas en el archivo.

Rúbrica de los registros, libros y papeles que hay en el archivo del reino de Aragón, empezada en $1660^{401}$

La pieza documental constituye posiblemente el mejor instrumento descriptivo del archivo anterior al inventario de José de Yoldi (17491750). ${ }^{402}$ En él se localiza la mayor parte de las tipologías documentales con indicación expresa de su ubicación en los armarios del archivo. ${ }^{403}$ Ricardo del Arco informa erróneamente que este inventario lo elaboró Vicencio Juan de Lastanosa, basándose en las indicaciones que se encuentran en los preliminares de su Tratado de la Moneda Jaquesa. Sin embargo,

401 A.D.P.Z., leg. 654-1.

402 Ricardo del Arco (1934), p. 288: «Hállase este manuscrito en el Archivo de la Diputación Provincial de Zaragoza, legajo 654, número 1. Es un volumen encuadernado en pergamino, con el escudo de armas del Reino estampado en oro en las dos tapas. Según en esta rúbrica se dice, se empezó a redactar en septiembre del año 1660; consta de 152 folios, no todos escritos, pues al fin de cada una de las secciones en que se divide quedaron hojas en blanco. Es de interés para conocer los fondos que tuvo el Archivo y poder puntualizar los registros y otros documentos perdidos. La letra es clara y el manuscrito se conserva en buen estado. Consta que Lastanosa formó este índice por el elogio que el citado Vidania le dedicó en su carta». Latassa dice que fue trabajo de utilidad, prolijo e inteligente. Cf. Gómez Uriel (1884-1886), vol. 2, p. 116.

403 Antonio Peiró (1998), p. 90. 
la autoría de Lastanosa no queda despejada en el propio documento. De hecho, fue Blas Asensio Monterde quien ofreció los resultados de dicho trabajo a los diputados del reino, como se indica en la dedicatoria del propio inventario. Otro dato que confirma la autoría de este trabajo es el suministrado por otro «indizador» del archivo del reino, don José de Yoldi, autor del inventario del año 1749. Al abrir el armario número 1 del archivo, encontró el conjunto de rúbricas, índices e inventarios del archivo. Entre ellas, indicaba, se encontraba la «Rúbrica antigua de los papeles de este archivo, hecha por Gabriel Blas Asencio Monterde». ${ }^{404}$

Tanto es así que el 26 de abril de 1694 se documenta el nombramiento de «asistente» del citado Monterde para componer los «papeles del archivo» en la persona de Salvador de Castro. ${ }^{405} \mathrm{El}$ ingente volumen de datos e informaciones documentales anotadas en dicho inventario fueron el resultado de unas tareas dilatadas en el tiempo. Junto al acto formal de nombramiento de ayudante en las tareas de organización documental, se anotaron detalladamente las actividades y pasos necesarios para conseguir dicho objetivo. Por una parte, se hacía hincapié en la necesidad de mantener un registro de salidas de escrituras del archivo con indicación sucinta del documento extraído «expressando en él qué papel sale, de qué tela, almario y ligarça para que a tiempo de restituirse al archibo lo pueda con facilidad colocar en su mismo lugar». Un aspecto de capital importancia en todo el procedimiento admi-

404 A.D.P.Z., leg. 654-1: «Rúbrica de los registros, libros, processos y papeles que ai en el Archibo de el Reino de Aragón, de los títulos que tienen y de qué años son y en qué almarios están los de cada calidad, por sus números y centenarios. Anla mandado haçer los illustrísimos señores los diputados de el dicho Reyno, [lista de diputados] A Grabiel Blas Asensio Monterde, que la ofreze con temor a la censura de muchos, si bien con esperanças de lograr su trabajo con el amparo y apoyo que espera de los Illustrísimos señores diputados y si ése mereciese, ofreçe el continuar en otros yndizes de lo que contienen dichos registros y papeles. Enpezóse a hazer esta rúbrica en el primero de el mes de septiembre de el año 1660».

405 Registro de actos comunes del año 1693, A.D.P.Z., ms. 601, f. 178r-178v: «Nominación de asistente para los papeles del archivo en favor de Antonio Salvador de Castro, en ayudante de Monterde. Attendido que para la conserbación y buena dirección de los papeles del archibo del consistorio se necesita de sujeto que asista con la puntualidad que es menester siempre que se hubiere de subir a sacar algún registro, libro negro, o qualquier otro papel. Y tener Blas Asensio Monterte con este encargo todos los temas que respetan a interesse del consistorio, por esta causa menos tiempo para manejar los papeles del archibo con el orden y claridad que desea el consistorio para evitar el dispendio grande de intereses que ha ocasionado el notar la providencia combiniente. Por tanto, sus señorías nombraron para aiudante de Blas Asensio Monterde a Antonio Salbador de Castro, para que se instruiya y ciude del archibo de la diputación, executando las advertencias siguientes». 
nistrativo era la obligación de que el ayudante obligase a los notarios de la Diputación a que remitiesen los registros y documentos concluidos al archivo con el fin de que no se perdiesen en las escribanías. Y cada registro debía incorporar al principio de sus hojas un índice de su contenido, así como todas las hojas foliadas. En definitiva, se insistía en el proceso de remisión de fondos desde las oficinas/escribanías productoras al archivo, para «que el dicho aiudante los ponga por su orden en la matrícula y ligarça de sus telas y en los almarios a cada especie correspondientes». ${ }^{406}$

Así, como veremos más adelante, simultáneamente a los trabajos de Monterde que se concretaron en el inventario de todas las series del archivo de la Diputación, se ejecutaron las tareas de descripción y resumen documental por parte de Audina y Benedid, que darían como fruto el índice-rúbrica de las cosas y sucesos más dignos de memoria contenidos en los registros de actos comunes.

Tomás Fermín de Lezaun, «Noticia del índice y rúbricas del Archivo de la Diputación del Reyno»

Según Latassa, el hijo del archivero de la antigua Diputación del reino Pedro Lezaun elaboró buena parte de su producción escrita tomando como fuentes de referencia los documentos custodiados en dicho archivo. Fruto de su actividad investigadora es un número de obras documentales sobre los instrumentos descriptivos del archivo, así como una interesante colección de resúmenes de los registros de actos comunes titulada Apuntaciones históricas. ${ }^{407}$ Este manuscrito no lo he localizado a pesar de las noticias de su elaboración.

José de Yoldi, "Índice de las escrituras del archivo del Reino de Aragón (1749-1750)» 408

Durante el siglo XVIII, la nueva administración borbónica, deseosa de aumentar sus recursos económicos para llevar a cabo su política reformista,

406 Registro de actos comunes del año 1693, A.D.P.Z., ms. 601, f. 178r-178v.

407 Estas apuntaciones históricas se hallan custodiadas en la Biblioteca Nacional de Madrid, mss. 9823, 9824 y 9825. Por su parte, en la biblioteca de las Cortes de Aragón se conserva una copia en microfilm del resto de estas apuntaciones.

408 A.G.S., Secretaría y Superintendencia de Hacienda, leg. 539. Diego Navarro Bonilla $(2000 a)$. 
pretende aumentar la carga fiscal de los territorios de la corona de Aragón; para ello necesita recurrir al testimonio escrito, con objeto de averiguar el carácter y la cuantía de las rentas gestionadas en el caso del reino de Aragón por la Diputación. Por consiguiente, la desaparición de las instituciones forales no llevó aparejado el olvido o la destrucción del archivo del reino donde se guardaba la constancia documental de esas rentas. Muy al contrario, el desvelo e interés mostrado por el archivo del reino fue una constante que tuvo su más acabado resultado a mediados del siglo XVIII, con la elaboración del ya citado índice de José de Yoldi. Se trata del más completo y riguroso inventario del archivo del reino, llegando incluso en algunos casos al nivel de catálogo documental por su exhaustividad descriptiva.

Será a partir de diciembre de 1749 cuando se inicien definitivamente los trámites necesarios para que el responsable del archivo de la bailía y maestre racional, don José de Yoldi, pase a elaborar el inventario de sus fondos, aunque auxiliado por Lezaun. En la orden que se comunica a Yoldi, se le indica que debe arreglar el archivo del reino de Aragón y mantener informado al intendente de Aragón acerca de todo lo que necesite para cumplir esta misión. Además, se le advierte que, cada semana, debe remitir un «índice» de todo lo que vaya revisando. El conjunto de estos índices, descriptivos de todo el contenido de los armarios del antiguo archivo de Aragón, constituyen el inventario completo de sus fondos. ${ }^{409}$

El día 9 de diciembre de 1749, el intendente de Aragón, el marqués de la Fresneda, aconsejaba al marqués de la Ensenada, nombrado en 1743 secretario de Hacienda, Guerra, Marina, Indias y Estado, que cada archivero, Yoldi y Lezaun, de forma independiente, se encargase de la reorganización de cada uno de sus dos archivos, porque «se mantiene en el maior avandono, mui especialmente el de Vaylía o Maestre Racional». ${ }^{410} \mathrm{La}$ orden de reconocer y ordenar la documentación de este segundo archivo fue recibida por Yoldi, quien, en carta fechada ese mismo día 9 de diciembre, se comprometía a cumplir "con el mayor celo y aplicación». ${ }^{411}$ Sin embargo, la idea inicial de que cada archivero atendiese por separado el archivo de su responsabilidad será modificada por mandato regio, cuando

409 Vid. el apéndice documental de Diego Navarro Bonilla (2000a).

410 Ibídem, apéndice documental, doc. n. ${ }^{\circ} 2$

411 Ibídem, apéndice documental, doc. n. ${ }^{\circ} 4$. 
el marqués de la Fresneda informe acerca del nombramiento de Yoldi para arreglar los dos archivos: no sólo el que ya tenía encomendado, el de bailía y maestre racional, sino también el del reino de Aragón (conferido inicialmente a Lezaun). ${ }^{412}$

El método de trabajo para elaborar este inventario consistía en abrir cada uno de los 88 armarios que compusieron el archivo del reino y anotar minuciosamente su contenido. Al abrir las puertas de cada armario, es muy probable que Yoldi encontrase pegadas a ellas una hoja de contenido en cada armario. Conforme examina el contenido de cada armario, anota con precisión los documentos allí albergados. Si se trata de documentos sueltos, los identifica perfectamente a través de un completo resumen. Cuando se trata de ligarzas, también examina su contenido y desciende a un nivel descriptivo catalográfico. Por contra, cuando se trata de series documentales, se limita a ofrecer los datos de inventario: número de armario, tipología y año del volumen.

Con respecto a los instrumentos de descripción que se hallaban a mano en el primer armario del archivo, Yoldi encuentra que existían los siguientes, agrupados bajo el término «índices y rúbricas»:

Almario $10^{\circ}$

Yndices y Rúbricas

En este almario se hallarán diez libros rubricados con los números del margen que contienen lo siguiente:

1. ${ }^{\circ}$ Epílogo y minuta de los registros de actos comunes hechos desde el año de 1470 hasta el de 1603 en el qual se hallarán juntamente los nombres de los diputados que tubo este reyno desde dicho año hasta el de 1628. Es un libro grande con cubierta de tabla. ${ }^{413}$

2. ${ }^{\circ}$ Borrador del sobredicho libro con cubiertas de pergamino y dos quaernos que aluden a lo mismo. ${ }^{414}$

412 Ibídem, apéndice documental, doc. n. ${ }^{\circ} 1$.

413 El extracto de las noticias más importantes de los registros comunes fechados entre 1470 y 1603 se encuentra en dos piezas documentales: un primer borrador del «índice» (R.A.H., ms. 9/671) y el índice original final (A.D.P.Z., ms. 290). En la propia Real Academia se encuentra un «Resumen de los registros de actos comunes de Aragón, desde 1520 a 1539 ", R.A.H., ms. 9/672.

414 R.A.H., mss. 9/671 y 9/672. 
3. ${ }^{\circ}$ Yndice sumario de las cosas y sucesos más dignos de memoria archibados en los registros de actos comunes desde el año de 1600 hasta el año de 1700. Concluido en 1703.415

4. ${ }^{\circ}$ Forma de cómo se han de celebrar las Cortes en el Reyno de Aragón compuesta por Gerónimo Martel, coronista del reyno. 416

5. ${ }^{\circ}$ Libro del mismo título y forma compuesto por Gerónimo Blancas, coronista del reyno: contiene al fin una adicción a dicho libro, hecha por Juan Mathías Esteban, lugartheniente de maestre racional de Aragón. ${ }^{417}$

6. ${ }^{\circ}$ Ordinaciones hechas en cortes por don Juan de Aragón, administrador perpetuo del Arzobispado de Zaragoza, pertenecientes al oficio de los diputados; hallaránse en dos libros con cubiertas: los dos están juntos y rubricados con dicho número $6 .^{\circ}$

7. ${ }^{\circ}$ Cabreo de censales, vendiciones, luiciones, cesiones, sentencias, consignaciones, substituciones, testamentos, difiniciones, reduciones de censales y cabreos, hechos en los centenarios $1300=1400=$ y 1500.418

8. ${ }^{\circ}$ Yndice de los procesos que deben hallarse en el Archibo como son los de ynseculados, de súplicas, de denunciaciones, de informaciones, de recepciones de testigos, de viedas, de panes y carnes, de causas civiles y criminales, de fraudes y cosas del general [?] y soluciones de sisas, cabrebaciones de censales, consultas, copias de procesos de la corte del Justicia de Aragón y Zalmedina de la ciudad de Zaragoza. ${ }^{419}$

9. ${ }^{\circ}$ Ordinaciones de la Diputación signadas por Juan Prat, ${ }^{420}$ notario del número de la ciudad de Zaragoza en los años $1519=1520$ y $1521 .^{421}$

415 A.D.P.Z., ms. 622. Dedicado a los diputados por Francisco de Audina y Benedid, ayudado por el doctor José Baltasar Arañón y Lumbier.

416 En la Biblioteca Nacional de Madrid se conserva un libro titulado Forma de celebrar Cortes en Aragón, B.N.E., ms. 453. Por el momento nos es difícil asegurar que se trate de la misma obra conservada original en el archivo de la Diputación del reino de Aragón. Indicamos la conocida edición de Martel de la Forma de celebrar Cortes en Aragón escrita por.. Chronista del Reyno. Dedicada a los ilustrísimos señores Diputados del Reyno, Zaragoza, 1641. Existe ed. facs. a cargo de Guillermo Redondo y Esteban Sarasa, Zaragoza, Cortes de Aragón, 1984.

417 Juan Matías Esteban y Eraso, Adiciones al libro de Jerónimo de Blancas intitulado "Modo de proceder en Cortes de Aragón", 1611, B.N.E., ms. 453.

418 Podría tratarse del inventario de luiciones de censales (1300-1586), A.D.P.Z., leg. 681-3. ${ }^{\circ}$

419 Podría tratarse de las rúbricas o inventarios de procesos existentes en el archivo. S. XVII A.D.P.Z., leg. 752-10.

420 Es muy probable que se trate del mismo Juan Prat, «notario del archiu donde están los processos de la corte del Justicia de Aragón y como notario de los siete consejeros [...] y como numerador de las cartas de los libros de los administradores del general», que a 8 de junio de 1525 recibió quinientos sueldos por su oficio de archivero.

421 A.D.P.Z., ms. 657. También existe copia en el A.M.Z., ms. 15. Estas ordinaciones para el régimen de la Diputación fueron publicadas por Savall y Penén (1866), vol. 2, pp. 320 y ss. 
10. ${ }^{\circ}$ Rúbrica antigua de los papeles de este archivo, hecha por Gabriel Blas Asencio Monterde. ${ }^{422}$

11. ${ }^{\circ}$ Libro de deliberaciones hechas por los diputados del año de 1619.

Zaragoza, 23 de diciembre de 1749.

Que muchos de los papeles que se hallan en este archivo se avían rubricado de tiempo de su establecimiento con el número del almario y el que correspondía a su colocación. Y assí, considerando que de variar los respectivos números podía resultar alguna confusión, ha parecido reglarlo y expresarlos en este yndice, siguiendo el cálculo de sus números, sin atender particularmente a lo correlativo de las fechas y de los asumptos, porque esto por el yndice de cada almario se descubre a primera vista, y variar los números impidiría tal vez hallarse el papel que se busque con la prontitud y claridad que se desea.

Fernando José de Velasco, «Ymbentario de diferentes papeles y escrituras que se hallan en el archivo deste reino de Aragón copiado del libro cabreo u bezerro de dicho archivo desde el día 12 hasta el 17 de nobiembre del año de $1750 »^{423}$

En diciembre de 1750, varios meses después de que José de Yoldi finalizase el inventario del archivo del reino de Aragón, solicitó el fiscal de la Audiencia don Fernando José de Velasco acceder a dicho fondo. ${ }^{424}$ Velasco buscaba datos para completar su historia eclesiástica y había paralizado su consecución hasta obtener permiso oficial. A tal efecto, el archivero José de Yoldi escribió al marqués de la Ensenada informándole de la petición: "Y haviéndome avisado el intendente que don Fernando de Belasco, ministro de la sala del crimen de esta Audiencia se hallava con comisión de Su Majestad para recoger de todos los archivos de este reino las noticias conducentes a la Historia Eclesiástica que se está escriviendo y que a este fin le serían mui útiles las que yo adquirí en el reconocimiento que hice de aquel archivo, he suspendido executarlo hasta tener orden de Vuestra Excelencia especialmente de lo tocante a las bullas por subsistir con la formalidad correspondiente el inventario que VE me mandó hacer».

422 Rúbrica de los reguistros, libros, processos y papeles que ai en el Archibo del Reino de Aragón. De los títulos que tienen y de qué años son y en qué almarios están los de cada calidad, por sus números y centenarios [...] Enpezóse a hazer esta rúbrica en el primero del mes de septiembre de el año 1660. A.D.P.Z., ms. 654-1.

423 B.N.E., ms. 1264.

424 A.G.S., Secretaría y Superintendencia de Hacienda, ms. 539. 
Finalmente, como consecuencia de la respuesta positiva y tras franquearle el acceso al archivo del reino, Fernando José de Velasco elaboró un a modo de borrador particular de todos aquellos documentos interesantes para su investigación. Sin embargo, sus notas constituyen un inventario general de todo el archivo, aunque, insistimos, con carácter de borrador personal. De esta pieza documental da escueta información un trabajo sobre fuentes documentales relativas a Aragón custodiadas en la Biblioteca Nacional y en la Real Academia de la Historia. ${ }^{425}$ El hecho de que este artículo no incluya la signatura de los ítemes descritos, unido a la circunstancia de que el catálogo general de manuscritos de la citada Biblioteca Nacional confunda el archivo del reino con el de la corona de Aragón en Barcelona, propician la consiguiente dificultad en encontrar este somero inventario.

Consiste este manuscrito en 66 folios que registran los trabajos de copia de escrituras llevadas a cabo por este oficial a finales de 1750. F. José de Velasco estuvo comisionado bajo la orden de don José de Carvajal para inspeccionar los archivos de Aragón. Como resultado, esta pieza documental describe el contenido de los armarios del archivo dividiendo la descripción en legajos, aunque, como indica su autor, es copia del cabreo o registro de las escrituras del archivo del reino.

Junto a esta descripción general existe a continuación una «minuta de los papeles y documentos de alguna consideración que hasta oy [en blanco] de diziembre del corriente año de 1750 he podido descubrir en el Archivo del Reyno de Aragón». En esta selección documental aparecen bulas, breves papales, correspondencia con el nuncio, cartas reales sobre los ministros de la sede apostólica y su jurisdicción, procesos de manifestación, el proceso de la sucesión del reino tras la muerte de Martín I, testamentos reales, copias de documentos pertenecientes a Zurita, etc.

También se incluyen copias de cartas del rey Felipe III a los diputados de Aragón en los años 1607, 1609 y 1611. A continuación, el autor se detuvo en una serie de gran importancia para analizar la andadura histórica de la Diputación del reino: los registros de cartas misivas y responsivas, comenzando en el "primero tomo de los 25 enquadernados que se encuentran en el Archivo, de cartas de Su Majestad, sus ministros, universidades y particulares, que escrivían a los diputados de el Reyno sobre

425 Sergio Castillo (1994). 
varios asumptos». Este primer registro comenzaba en el año 1480 hasta el de 1605: «está rotulado desde el año 1480 hasta el de 1605 y con efecto abraza todos estos años pero se entiende que desde el de 480 hasta 500 sólo hay quatro cartas; en 1500, 59 y las restantes (que son muchas) en la centuria de 600, pasando a otros tomos». ${ }^{426} \mathrm{El}$ segundo tomo de cartas enviadas a la Diputación comprende desde 1606 hasta 1610 y de nuevo selecciona un grupo que considera de interés. Finalmente, el manuscrito se cierra con una breve descripción del contenido del registro de cartas misivas del año 1592, con copia de tres cartas.

En conjunto, este manuscrito descriptivo y sesgado del contenido del archivo muestra signos de constituir unos apuntes de trabajo de campo o las anotaciones necesarias en la inspección «a pie de archivo». De hecho, el lomo del manuscrito indica claramente esta naturaleza: "VELASCO | Noticias | sacadas | DEL | Archivo | del | Reyno | de |Arogón [sic]».

\subsubsection{Inventarios de series específicas}

Los inventarios que se indican a continuación mantienen en general una disposición textual muy similar. Dividida la hoja en columnas, la información se dispone de manera sintética para facilitar la lectura y localización documental.

Inventario de definiciones de censales y de luiciones ${ }^{427}$

En el archivo de la Diputación Provincial de Zaragoza, este manuscrito falta incomprensiblemente, a pesar de estar consignado en las fichas descriptivas

Inventario de revendiciones de censos de los siglos XV y XVI existentes en el archivo de la antigua Diputación del reino ${ }^{428}$

Los datos del inventario se disponen en cuatro columnas correspondientes a los siguientes conceptos: número correlativo, revendiciones (extracto del contenido), cantidad, año.

426 B.N.E., ms. 1264, f. 34r.

427 A.D.P.Z., leg. 626-21.

428 A.D.P.Z., leg. 582-13. La descripción de este inventario aparece en las fichas de la actual Diputación Provincial de Zaragoza como inventario de «renunciaciones» de censales, sin duda error de transcripción al entender la abreviatura Revenon. (revendición) por renunciación. 
Inventario de sentencias de censales de los años 1400 a $1470^{429}$

Ordenado por número de ligámenes y, a continuación, numerus currens, sentencias (extracto), cantidad, año.

Inventario de procesos de súplicas del siglo $\mathrm{XVI}^{430}$

Ordenados alfabéticamente, sin indicación de cajón, sólo año.

Rúbricas o inventarios de procesos existentes en el archivo del reino. S. XVII ${ }^{431}$

Se detallan procesos de sumarias informaciones y se encabeza por el número de armario "Almario primero de informaciones y amisiones de recepciones de testigos». «Almario de cabrebaciones, consultas, copias de procesos de la Corte del Justicia de Aragón, criminales [texto barrado] treguas y soluciones de sisas». También se incluyen procesos de vedas de panes y carnes.

Inventario de luiciones de censales 1300-1586 432

Letra del siglo XVI. Fechas extremas, 1300-1586.

Inventario de escrituras de censales ${ }^{433}$

Letra del siglo XVI. Fechas extremas, 1391-1586. En este inventario, la información se dispone en cuatro columnas correspondientes al número correlativo, censales, pensión (interés dejado por dichos censales) y año.

Inventario de vendiciones y sentencias de censales ${ }^{434}$

Letra del siglo XVI. Fechas extremas, 1398-1573.

Rúbrica de sindicados, privilegios, etc., que había en el archivo histórico de la Diputación del reino ${ }^{435}$

Fragmento de inventario donde se indican las capitulaciones matrimoniales que existían en el archivo de la Diputación del reino. Los ele-

429 A.D.P.Z., leg. 582-14.

430 A.D.P.Z., leg. 582-15.

431 A.D.P.Z., leg. 752-10.

432 A.D.P.Z., leg. 681-4.

433 A.D.P.Z., leg. 681-3.

434 A.D.P.Z., leg. 681-5.

435 A.D.P.Z., leg. 750-28, 29 у 30. 
mentos de información se disponen en cinco columnas para cada capitulación: letra, número, capitoles, cantidad y año. A continuación, y con similar disposición, se indican las sentencias de censales, ordenados por ligámenes con cuatro columnas para cada sentencia: número, sentencia, pensión y año. Sigue con testamentos de los siglos XIV, XV y XVI, tutelas y curadurías, intimas y recuestas, sentencias de censales del siglo XV.

\subsection{3. Índices y resúmenes de los registros de actos comunes}

Como complemento de los inventarios destinados a la localización de las series documentales en el archivo existe, sobre todo desde el siglo XVII, un conjunto de instrumentos documentales de extracción de contenido de una serie particular: los registros de actos comunes que testimonian la actividad cotidiana del consistorio de la Diputación. El elevado número y el abultado volumen informativo de estos registros hizo necesario recurrir a tareas de resumen de contenido, que fueron encomendadas a personas peritas en el manejo de la documentación y su síntesis informativa. Se conseguía de este modo, a través de índices y resúmenes, facilitar el acceso y la localización de las noticias más interesantes contenidas en esta serie. Se cuenta con los siguientes:

Índice de los registros de diputados en 1603; disposición del archivo de Aragón ${ }^{436}$

Con esta signatura existe en la Real Academia de la Historia lo que parece constituir un borrador del índice por asuntos de los registros de actos comunes que finalizaría Juan Matías Esteban en 1603. En realidad, su desigual factura y contenido permite conjeturar que se trata de un registro donde se anotaron los registros existentes en el archivo del reino, la extracción de noticias de interés, borradores, etc. Este ejemplar incompleto de la Academia se encabeza con la dedicatoria del autor a los diputados del reino.

De Juan Matías Esteban y Eraso nos dice Latassa que nació en Zaragoza en 1564 y que accedió a diferentes puestos dentro de la administración del reino, ocupando el cargo de secretario del reino de Aragón y teniente de maestre racional. En 1593 desempeñó el oficio de diputado

436 R.A.H., ms. 9/671. 
y falleció en 1628. ${ }^{437}$ Conocedor por tanto de las estructuras administrativas de la Diputación, pudo elaborar uno de los índices resumen de los registros de actos comunes del archivo del reino. Asimismo, fruto de su conocimiento del archivo, y derivados del trabajo de resumen documental de dichos registros, fueron sus Linajes de Nobles e Infanzones del Reino de Aragón [...] averiguados e recogidos por tiempo de 50 años que trabajó en esto, reconociendo los registros de la Diputación, Corte del Justicia de Aragón, Baylía General, Oficios de Maestre Racional, Escrituras, Crónicas, Cortes y otros instrumentos públicos. ${ }^{438}$

Durante el año 1600 se recibió una real orden de Felipe III relativa al gasto para poner en orden las escrituras y papeles del archivo del reino. ${ }^{439}$ En un primer momento, este índice había sido encargado a mosén Diego de Espés el 7 de julio de $1600 .{ }^{440}$ La fama de Espés como

437 Miguel Gómez Uriel (1884-1886), vol. 1, p. 450.

438 Una copia de esta obra, en B.N.E., mss. 11427 y 11428: Linages de nobles, ynfanzones de Aragón | y sus descendencias. | Escritos por Juan Mathias Esteban, theniente de | Maestre Racional de aquel Reyno. | Observados y aberiguados y recogidos por tiempo | de cinquenta años que travajó en esto. | Reconociendo los rexistros de la Diputación | Corte de el Justicia de Aragón, Baylía General, | oficios de Maestre Racional, escripturas, | corónicas y otros instrumentos públicos. | Parte Primera | Comprehende las letras siguientes ABCDEFGHY Y lo añadido a lo que él recojió, está en- | tre dos cruces en la forma siguiente + + | Copiado por el cuidado y dilijencia de don Francisco Zazo y Rosillo | Coronista y Rey de Armas de su Magestad | Año de 1730 [colofón:] Es copia del original que hiçe sacar en la real bibliotheca de Su Majestad. Madrid y febrero 17 de 1730, al Francisco Zazo y Rosillo. Fin de la primera parte.

439 R.A.H., ms. 9/548, f. 85: «Haviendo visto el traslado que havéys embiado, con una carta de XIX del passado, de la consulta que los diputados desse Reyno quieren interponer en la corte del Justicia de Aragón para el gasto que se ha de hazer en poner en orden las escrituras y papeles de su archivo y para la rúbrica de los registros y actos comunes y índice de las obras de Çurita, es mi voluntad darles licencia para ello y así poder dar vos en mi nombre el consentimiento que se acostumbra. Dattum en Madrid, a XIX de abril, 1600. Yo el Rey. Villanueva, secretario. Al advogado fiscal de Aragón».

440 Registro de actos comunes del año 1600, A.D.P.Z., ms. 287, f. 72r: «Dicta et eadem die, mense et loco, estando congregados los dichos señores dipputados en el ministerio precedente, nombrados todos en conformidad etc. Satisfechos de las partes confianza, erudición, y las demás que en el maestro Mossén Diego de Espés, prasbítero domiçiliado en la çiudad de Caragoça, concurren, le nombraron diputaron y ligieron para que pueda reconoçer y reconozca el archivo del presente reyno con las personas que se le señalaren y todas las escripturas de aquél, cabrevándolas y haziendo rúbrica dellas con mucha puntualidad, cuydado y satisfaçión, el qual conacimiento [sic] de [?] dicho cargo, aceptó y juró inspectore de haberse bien y lealmente en satisfaçión de su cargo y guardar secreto. Ex quibus, etc.» 
archivero le llevó a desempeñar algunas tareas de organización documental hasta parar en el archivo del reino, como indica Ricardo del Arco: «Manejó con detención los fondos documentales de entrambos templos concatedralicios, por virtud del cargo que en éstos ostentó; y además el archivo de la mitra arzobispal, y el del Reino, merced a la buena acogida de su discípulo, el famoso cronista Gerónimo de Blancas, de quien heredó su copiosa librería». ${ }^{441}$ Pero tras su fallecimiento antes de ver culminado el trabajo de descripción documental, Matías y Esteban se hizo cargo del proyecto. Por la ápoca o recibo del pago por la elaboración del índice nos consta que fue Juan Matías Esteban quien el 31 de mayo de 1603 otorgaba haber recibido de «los señores diputados del presente reyno y por manos del señor don Martín Pérez de Pomar, uno dellos dozientas libras jaquesas, por los trabajos que he sustenido en acabar el índice de los registros de los actos comunes de la dipputación, que principió el maestro Diego de Espés, ya diffunto, los quales se me pagan en virtud de una consulta de la corte del Justicia de Aragón». ${ }^{442}$

El sistema de localización de los actos jurídicos documentados, especificado por Esteban y Eraso, será el mismo que se siga en índices posteriores. En primer lugar se indica el resumen del contenido y a la derecha se colocan tres columnas numéricas que indican: la primera, el número de registro total dentro de la serie; la segunda, el número de folio dentro del registro concreto; y la tercera, el número de acto jurídico dentro del mismo registro. En resumen, quedaba de esta sencilla manera dispuesto el orden de acceso secuencial a la información de tales series. ${ }^{443}$ En definitiva, se

441 Ricardo del Arco (1918).

442 Registro de ápocas de salarios, comisiones y consultas año de 1602, A.D.P.Z., ms. 297, f. 62r.

443 R.A.H., ms. 9/671: «Siendo Vuestras señorías los protectores deste Reino, por sus officios es forçoso que cada día tengan negocios muy graves que tratar y como para la deliberación dél los sea muy importante el tener noticia de los que se an ofrecido a los señores diputados predecesores de vuestras señorías y de sus resoluciones, pues siempre se an hecho con tanto acuerdo y consexo como a todos es notorio, de ninguna parte se podrá esto sacar sino de los registros de actos comunes que tienen en su archivo, por estar en ellos los negocios y succesos que en el consistorio de Vuestras Señorías an tratado; y como la escritura dello sea muy larga y de muchos años, era mucha la dificultad que avía en hallar lo que en ellos se buscava, y assí para facilitarla, vuestras señorías mandaron al mossen Diego Espés que sacasse un índice de todos estos registros, el qual aviéndolo comenzado, no pudo pro- 
ordena alfabéticamente por asuntos, con indicación del año y del folio del registro original del que se toma el extracto.

\section{Índice de los registros de actos comunes 1475 a $1601^{444}$}

Este índice es con toda seguridad el comenzado por Diego de Espés y acabado por Juan Matías Esteban y Eraso. Sólo es índice, y no incluye extracto, como hizo Lezaun en sus Apuntaciones históricas. Esta pieza documental se complementa con el índice terminado en 1703 por Audina y Benedid, dando lugar entonces a dos índices generales: el correspondiente a los años 1475-1601 y el Índice sumario de las cosas y sucesos más dignos de memoria archivados en los registros de actos comunes desde el año 1600 hasta el 1700, concluido por el de 1703. Lo dedica a los señores diputados Francisco de Audina y Benedid, quien se valió para realizar éste del doctor Joseph Baltasar Arañón y Lumbier. ${ }^{445}$

La fortuna del índice anterior (1475-1601) propició que se continuase todo el trabajo de descripción de los registros de actos comunes como una de las series fundamentales de la producción escrita de los

seguirlo por su muerte y pareciendo a vuestras señorías que por ella no parasse su contento, me lo mandaron proseguir y assí lo he hecho con mucha voluntad de acertar a servir a vuestras señorías. Este Reino quedó muy obligado a reconocer toda la vida el beneficio grande que vuestras señorías le han hecho en mandar hazer este índice, pues con él los señores diputados que de oy adelante lo fueren, tendrán entera claridad y luz y io quedo muy obligado a servir a vuestras señorías la merced y confianza que de mi an hecho a quien nuestro señor guarde como quede. En Caragoça y março a 13 del año mil seyscientos y tres. Besa las manos de vuestras señorías, Juan Mathías Estevan. Los números que están señalados en las márgenes deste índice corresponden a los años del registro donde aquello está escrito y al número y folio y título de aquél; y entiéndesse desta manera que los de la

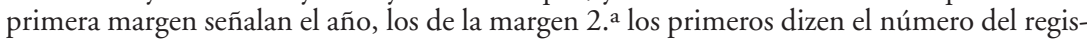
tro; los segundos el folio de aquél y los terçeros el título de aquel registro como si se quisiesse saber: Arciprestado de la Val de Onsella de la Iglesia de Jaca, en donde se ha de hallar, verán que está en el año 1473 y en el número 5 que es el $5 .^{\circ}$ registro en el folio 151 y en el título 83 de aquel registro. Al fin de cada letra de las deste índice se an dexado algunas oxas blancas para que se pueda continuar en ellas lo que se asentare en los registros de actos comunes desde el año 1601 en adelante, pues hasta este tiempo está en él continuado».

444 A.D.P.Z., ms. 290 y R.A.H., ms. 9/671, y el de los años 1601-1700: A.D.P.Z., ms. 622.

445 A.D.P.Z., ms. 622. En las Bibliotecas de Latassa se localiza esta obra, y de su autor indica que fue "ciudadano de Zaragoza y perito en el registro de archivos, escribió en 1703 índice de las cosas y sucesos más dignos de memoria archivados en los Regitros de actos comunes de la Diputación del Reino de Aragón». 
diputados del reino. En agosto de 1620 se subrayó la necesidad de seguir con el índice de los registros siguientes. De hecho, los diputados nombraron a Juan Luis de Sora, condiputado, para comenzar las tareas de reconocimiento del archivo y finalmente la elaboración de un índice similar al terminado en 1603 , que sirviera para la utilidad primero de las leyes y después para el normal funcionamiento administrativo. ${ }^{446} \mathrm{El}$ resultado final sería el índice iniciado por Juan Luis de Sora y finalizado por Audina y Benedid en 1703:

Atendido que en 1603 se hizo un índice y general rubricario de todos los registros de actos comunes y otros, y de todos los documentos, instrumentos, escrituras, privilegios reales, cartas, papeles y otros de consideración, cuia obra había sido en extremo útil para todo, y atendido que después de la fecha de dichos ýndices y colocación de papeles que se hizo se havían aumentado muchos registros y papeles y no estavan en ýndice, nombraron al condiputado Sora para hacer un nuevo índice y colocar conforme a él todos los registros y papeles del archivo, asistiendo el condiputado López de Heredia. ${ }^{447}$

Los avatares administrativos previos a la elaboración de este índice se documentan a lo largo de 1693 y 1694. En primer lugar, el consistorio de la Diputación tuvo que interponer una consulta a la corte del Justicia para poder disponer de dinero suficiente con el fin de sufragar el gasto de su confección. ${ }^{448} \mathrm{La}$ consulta se resolvió favorablemente y se pagó a Monterde, que entregó la carta de pago a Juan de Audina, que reconoció (median-

446 Registro de actos comunes de 1620, A.D.P.Z., ms. 356, f. 55v-57r. Vid. apéndice documental, n. ${ }^{\circ} 2$.

447 Tomás Fermín de Lezaun y Tornos, Apuntaciones históricas..., B.N.E., ms. 9824, f. 100r. Cf. Registro de actos comunes del año 1620, A.D.P.Z., ms. 356, f. 55v-57v.

448 Registro de actos comunes del año 1693, A.D.P.Z., ms. 601, antes de folio 27: «Dizen que a vuestra señoría illustrísima le consta y es notorio como los dichos illustrísimos señores diputados sus principales, juntos con el illustrísimo señor don Bruno García de la Porta, su condiputado, en cumplimiento de su officio y obligación de attender a la caussa pública del Reyno, allándose el archibo de la Diputación muy necessitado de poner en orden los registros, procesos y escrituras que en él deven estar custodiados para remediar el grabe daño y perjuicio que de su desorden y confussión puede seguirse, el día quatro de mayo del presente año 1693 consultaron con la corte del illustrísimo señor justicia de Aragón si para dicho fin podían gastar de las cinco mil libras jaquesas destinadas por los fueros y actos de corte del presente reyno la cantidad de seyscientas libras jaquesas con más la de doscientas libras jaquesas para continuar el libro de las cossas memorables de dicha diputación que está en dicho archibo». 
te ápoca que se incorpora) haber recibido. ${ }^{449}$ En realidad, las tareas llevadas a cabo por Audina, Segarra y Monterde dieron como consecuencia documental la elaboración del segundo índice (1601-1703), por una parte, y el inventario de las series documentales del archivo del reino, por otra, entregado por Monterde a los diputados. Es decir, ambos repartieron el trabajo archivístico desarrollando por una parte el índice y por otra el inventario. ${ }^{450}$

Con respecto a las tareas documentales indispensables para extraer las noticias de los actos comunes y consignarlas en el índice, naturalmente era necesario que Audina consultase directamente todos los registros. Por ello, tres años antes de finalizar, los diputados del reino hacían constar la petición de Audina de ver dichos registros, haciendo hincapié en que no se le pagase en tanto no finalizase el trabajo descriptivo. ${ }^{451}$ Por último, el día 25 de mayo de 1703 Audina entregó el índice final para satisfacción de los diputados y memoria perpetua del contenido de los registros de actos comunes. ${ }^{452}$

449 Registro de actos comunes del año 1693, A.D.P.Z., ms. 601, f. 24v-25v: «1693, junio, 14: Sentencia del tribunal de cuentas sobre una cantidad para arreglar el archivo, 800 libras pagadas a Blas Asencio Monterde, portero de la diputación». Los diputados y los inquisidores de cuentas extractos se reúnen para ver si es válida dicha póliza expedida el 7 de mayo por los diputados a Monterde, "persona por cuia quenta havía de correr el componer todos los registros, processos, firmas y papeles que hay en el archibo del mismo consistorio en la forma y con los pactos que tenían combenidos mediante una capitulación que se havía de otorgar». Al final la declaran nula y el resultado es que, en vez de dar 800 de golpe, se le vayan pagando poco a poco, conforme vaya trabajando en el archivo, "para que le vayan librando poco a poco en los fines contenidos en la concordia del día once de mayo del dicho presente año, conforme vieren y aberiguaren que se va trabaxando la composición del archibo y su rúbrica».

450 Este inventario, en A.D.P.Z., leg. 654-1.

451 A.C.A., Manuscrito misceláneo n.o 220, f. 161: [al margen: del índize]: «Assí mesmo nos ha constado que Don Juan de Audina continúa el índice de todo lo contenido en los registros de el consistorio desde el año 1601 y para que se adelante obra tan importante y beneficiosa al Reyno encargamos a los señores diputados se le alarguen los registros que necesitare para su continuación, aiudando para esto el aver representado Don Juan de Audina a este tribunal que de ningún modo desea se le adelante cossa alguna, sino que se le dé satisfacción puntual después de aver trabaxado los registros que esperamos se le alarguen para que pueda proseguir esta obra».

452 Registro de actos comunes del año 1702, A.D.P.Z., ms. 618, f. 97r-97v: «Pareció don Juan Baudina [sic] y entregó a dichos señores diputados el índece de las cossas memorables que contienen los cien registros de actos comunes de dicha diputación que son los incluidos desde los años mil seiscientos y uno inclusibe hasta el de mil y setecientos y ocho; 
Las actividades conducentes a la elaboración de este índice sumario se encuentran precisamente en los mismos registros de actos comunes, fechados en abril de 1694. En estas líneas se advierte un hecho de especial interés para la localización de los actos jurídicos documentados. De hecho, al comienzo de casi todos los registros de actos comunes existe un índice que remite a los folios donde se encuentra dicho acto dentro de cada registro. El hecho de que se realicen con una letra posterior es debido a que, efectivamente, su indización se ejecutó tardíamente, concretamente a fines del siglo XVII. ${ }^{453}$

Los datos suministrados por la dedicatoria inicial de Audina a los diputados permiten apuntar algunas consideraciones sobre la conciencia documental del consistorio aragonés, así como sobre el asentamiento de la memoria mediante el testimonio escrito y el paso siguiente, desarrollado por los indizadores y resumidores de esa misma memoria. ${ }^{454}$ Se trataba de disipar el olvido mediante la escritura organizada y de acceder a ella mediante operaciones documentales de resumen y condensación informativa:

Illustrísimos señores: Esgrime el tiempo la inexorable segur, contra la sucesiva impertinencia de los días, siendo la máxima de su sañudo ceño el sepultar en los aterados horrores de la confussión todo lo pasado. Tan dilatado es el imperio de sus iras que el mundo todo, en los escarmientos que llora, es el coronista mayor de sus triunfos. Aún la tenaz reveldía de los mármoles y bronzes, siente desairada sus resistencia con el castigo fatal de su ruina. Todo lo que fue es nada y nada de lo que pasó tiene ser. Pero hay acertadas providencias de este illustrísimo Reyno, quitan al tiempo las armas de las manos e invertido el orden de las cosas, no se halla en el consistorio de V.S.I. tiempo pasado; todo lo pasado se advierte presente para el Govierno, para el exemplo y para la admiración. Practicáronlas los illustrísimos señores diputados del año 1692, quienes

illustres señores diputados han otorgado ápoca legítima de haberlos recevido conforme a la capitulación otorgada entre dicho illustrísimo reino y dicho don Juan Baudina, y assí mesmo se ha mandado le entreguen dicho índice a dicho don Juan Baudina para poner en él los nombres de los señores diputados que ha visto en dichos cien años para [reconocer?] dicha segunda copia de actos lo que contiene dicho índice y assí mismo dichos illustrísimos señores diputados deliberaron se le entregassen los veinte registros de la junta magna, los quales debe poner en índice dicho don Juan Baudina, conforme dicha capitulación».

453 Registro de actos comunes del año 1693, A.D.P.Z., ms. 601, f. 176v. Vid. apéndice documental, n. ${ }^{\circ} 5$.

454 Yndice sumario de las cosas y sucesos más dignos de memoria archibados en los registros de actos comunes desde el año de 1600 hasta el año de 1700. Concluido en 1703. A.D.P.Z., ms. 622. Vid. apéndice documental, n. ${ }^{\circ} 7$. 
resolvieron se pusiessen en índice los sucesos más dignos de memoria ya olvidados por el transcurso del tiempo, esparcidos y archivados en los registros de actos comunes desde el año 1600 asta el año 1700, restituiendo con esta resolución a nueva vida las noticias que el olvido sepultava muertas. ${ }^{455}$

En cualquier caso, el objetivo final de disipar el olvido de la memoria escrita custodiada en el archivo del reino pasa ineludiblemente por un plan de trabajo y una metodología de análisis documental cimentada en el conocimiento de los expertos que elaboraron índices, inventarios y el resto de instrumentos de descripción. En algunas ocasiones, el autor nos dejó auténticos manuales de cómo acceder a los fondos del archivo, cómo buscar la información y cómo recuperarla satisfactoriamente. Son las denominadas Ydeas o modos de encontrar escrituras, adjuntas a los propios inventarios o resúmenes. Tal es el caso del índice de Audina y Benedid. Si en la dedicatoria a los diputados se hacía toda una defensa de la organización documental como instrumento eficaz al servicio de la gestión y la función institucional, no fue menos destacado el relato del «Modo fácil de hallar los actos resumidos en este índize».

En párrafos anteriores hemos destacado la falta de un reglamento interno general del archivo, similar a los que en Simancas o Barcelona pudieran servir de guía y método de actuación. ${ }^{456}$ Sin embargo, las actividades archivísticas prolongadas durante más de dos siglos en el archivo del reino de Aragón dejaron como consecuencia no sólo instrumentos de descripción, sino también fragmentos dispersos de métodos de actuación. Reunidos, permiten contemplar el modo concreto en que se rigió el trabajo en el archivo. En este sentido, el «Modo» de Audina hace hincapié en varios aspectos que destacan por su conciencia archivística, guiada por el objetivo de la recuperación documental.

La ordenación del índice se hizo de manera alfabética. Cada término destacado hacía referencia a tres elementos de información: el nombre del acto, el nombre de la materia o el nombre de la persona, unidos en una misma secuencia. De modo que las noticias referidas al archivo del reino se hallarían tanto por la A de archivo como por la inicial de alguno de sus

455 A.D.P.Z., ms. 622.

456 Además de las reiteradamente citadas ordenanzas de Simancas, cabe señalar la primera guía del archivo real de Barcelona publicada por Rafael Conde y Delgado de Molina $(1998 b),(1999 a)$ y $(1999 b)$. 
archiveros o por la I de indice del archivo, o la C de cautela u orden de pago por haber mantenido trabajos en el archivo del reino. Junto a esta entrada, se incluye el año en que se documentó el acto jurídico y a continuación se diseña un método eficaz para recuperar las noticias de los registros de actos comunes, tipología a la que remite todo el índice. Así, junto a la entrada del término resaltado, el año y el contenido de la información, se adjunta una lista de tres números: el primero indica el número del registro de actos comunes dentro de la serie completa, el segundo señala el folio del registro donde está el acto y, finalmente, aparece el número que el acto documentado tiene en el propio registro, como figura en una entrada cualquiera del índice de Audina. ${ }^{457}$

Resumen de los registros de actos comunes 1520-1539458

Es un registro de 288 folios numerados que recoge las informaciones más destacadas contenidas en los registros de actos comunes de la Diputación durante el período indicado. Incluye copia literal de cartas y otras escrituras insertas en dichos registros. Sin embargo, no se indica su autoría ni otras circunstancias de su elaboración.

Noticias que aparecen en los libros del archivo de la antigua Diputación del Reino de Aragón que en virtud de real orden está a cargo de don Phelipe Fernández de Arias [...] $]^{459}$

La documentación depositada en el archivo del reino de Aragón fue objeto de la atención no sólo del propio consistorio aragonés, sino también de los historiadores de cada período. A la nómina oficial de cronistas aragoneses sucedió un importante número de eruditos e investigadores que en el siglo XVIII harían frecuentes incursiones en la documentación de la antigua Diputación: Lezaun y Tornos, Jordán de Asso, Velasco, Abbad y Lasierra, Traggia, etc. Casi todos ellos consultaron y copiaron documentos del archivo, pero también realizaron descripciones más o menos extensas de éste en diferentes borradores. Gracias a ellos conservamos una idea

457 Yndice sumario de las cosas y sucesos más dignos de memoria archibados en los registros de actos comunes desde el año de 1600 hasta el año de 1700. Concluido en 1703, A.D.P.Z., ms. 622. Vid. apéndice documental, n. ${ }^{\circ} 8$.

458 R.A.H., ms. 9/672.

459 R.A.H., Traggia, ms. 9/5219, f. 285. 
más aproximada del conjunto documental a finales del siglo XVIII, poco antes de su destrucción parcial.

Entre las varias noticias suministradas por los eruditos ilustrados, destacamos en estas líneas la que el escolapio Joaquín Traggia elaboró en mayo de 1792. ${ }^{460}$ Ayudado por el entonces archivero Felipe Fernández de Arias, ${ }^{461}$ autor a su vez de un interesante memorial sobre el archivo, consultó los fondos documentales y consignó un incompleto índice y resumen de los registros de actos comunes, encabezado de la siguiente manera:

Se empezó este reconocimiento día 24 de mayo de 1792.

Letra a

Al margen: este índice es índice del índice grande o cabreo a cuyos folios se remiten estas citas

\subsection{Documentación administrativa indicativa del contenido}

Fruto de la complejidad de las tareas burocráticas desarrolladas en el seno de la Diputación, así como del concepto de patrimonialidad y secreto que rodeaba al conjunto de las escrituras del reino, surgen diversas tipologías documentales que intentan precisamente controlar la situación de la documentación y contribuir a su localización continua. Por una parte, y como consecuencia del proceso administrativo llevado a cabo en el seno de las escribanías de la Diputación, las tipologías documentales, una vez tramitadas por el notario correspondiente, debían pasar a manos del secretario o archivero para su final depósito en el archivo. Al igual que pueda suceder en nuestros días, dicho envío era regularmente acompañado de hojas de remisión de fondos, incluidas por lo general en los registros de actos comunes. Por otra parte, los documentos custodiados en el archivo del reino fueron objeto de las más variadas consultas para resolver cuestiones de gobierno y de garantía de derechos individuales, para tomar decisiones por parte de la Monarquía o para servir de fuente histórica. Sin embargo, el uso más frecuente dado a tal conjunto documental provino sin duda de la propia

460 R.A.H., Traggia, ms. 9/5219, f. 284 r.

461 Vid. apéndice documental, n. ${ }^{\circ}$ 18: A.D.P.Z., leg. 755-11. 
institución que lo generaba. Y ante la habitual consulta y necesidad de registros y escrituras del reino, se observó paralelamente la costumbre de consignar por escrito las entradas y salidas de libros y registros del archivo en un registro especial conservado hasta nuestros días.

\subsubsection{Hojas de remisión}

Como hemos señalado, son frecuentes los listados de tipologías documentales tramitadas y remitidas al secretario de la Diputación para ser archivadas. De hecho, formalmente cada año debían concluirse los registros de actos comunes, ápocas y censales, asistencias, etc., del año anterior. Y cada escribanía efectuaba una relación de entrega, consignada generalmente en los actos comunes. De estas numerosas relaciones se entresaca, por una parte, la importante variedad documental gestionada por los notarios de la Diputación y, por otra, el volumen generado cada año.

Entre otros muchos casos documentados, conocemos el envío de los registros tramitados que hizo el notario extracto de la Diputación Miguel de Pardinilla al secretario López el 8 de junio de 1607: «satisfaciendo a la obligación en cada un año que al fin dél, conforme a fuero tengo de entregar los actos y escripturas en dicho año por mí testificados al secretario de la dipputación. Por tanto, en presencia de los testigos infraescriptos entregué a Pedro López los registros, actos y escripturas infraescriptas y siguientes: Registros de actos comunes, Registros de ápocas de censales, salarios comisiones y consultas, Registros de asistencias y pólizas, Registros de intimas de censales, Bastardelos notariales, Procesos de sumarias informaciones, Procesos de súplicas, Procesos civiles y criminales». Otro ejemplo es el listado, elaborado en mayo de 1615 por el secretario Pedro López de Quinto, de lo que debía subir al archivo procedente de las escribanías. ${ }^{462}$

462 Registro de actos comunes del año 1614, A.D.P.Z., ms. 334, f. 237v-244r: «Accedieron y subieron personalmente a la sala real de la dipputación para fin y efecto de abrir el archiu que dentro della el dicho reino tiene y en él poner y encerrar los registros, libros y papeles avajo insertos, el qual dicho archivo se alló bien y fielmente cerrado y fue abierto por los detenedores de dichas llaves y en él se pusieron encerraron como dicho es los registros, libros y papeles que Pedro López, secretario de la dipputación subió y dijo tenía en su poder y que cumpliendo con los actos de corte, fueros y observancias del presente reyno, los subía y se ofrecía presto y aparejado a subir los demás que en su poder tenía para el día que los dichos señores dipputados le asignasen y los que quedaron en dicho archivo son los siguientes: [Constituye un amplio listado de registros de actos comunes, ápocas de censales, matrículas de insaculados, asistencias y pólizas, bastardelos, etc.]». 
O los documentos que el ínclito y omnipresente Jerónimo de Naya recibió el primero de junio de 1651 de manos del notario José Felipe Sánchez, «el qual dixo que entregava como de hecho entregó a Gerónimo de Naya, secretario de los señores diputados, los procesos que tiene en la escrivanía del notario de la diputación y que se contienen en una memoria que ha entregado a mí dicho notario, la qual consta del tenor siguiente (inseratur). Todos los quales dichos procesos el dicho Jerónimo de Naya que presente estava, atorgó haver recibido en su poder». ${ }^{463}$

\subsubsection{Registros de entrada y salida de escrituras}

Ingreso y salida de documentos del archivo de la Diputación del reino. 1615-1710. ${ }^{464}$

Como constancia documentada del trasiego de escrituras entrantes y salientes del archivo, los diputados del reino llevaron cuenta puntual de los documentos que entraban y salían de los estantes del archivo. Este registro de entradas y salidas de escrituras comprende el período de los años 1615 a 1710. Constituye otra de las fuentes necesarias para comprender la importancia de los fondos del reino de Aragón, su consulta y circulación administrativa.

Formalmente, la información se dispone de manera que sean fácilmente identificables la fecha de entrada o salida, el órgano involucrado y la tipología específica, con indicación del año al que corresponde. En el caso de que se extraigan registros del archivo, es habitual consignar su retorno días después. Así, por ejemplo, el día 30 de julio de 1636 se sacaba del archivo del reino precisamente «un libro y en la cubierta dél que es de pergamino está intitulado libro de los actos y escrituras que entran y salen en este archivo. Y dentro en la primera oja está intitulado como se sigue: año 1615, Juan de Morlanes, notario; copia de los libros, registros, escrituras y papeles que Pedro López, secretario de la Diputación ha entregado a los señores diputados del presente Reyno de Aragón y se han puesto y entregado en el archiu de la dicha Diputación y sacado dicho libro, sus señorías mandaron cerrar dicho archivo». 465

463 Registro de actos comunes del año 1651, A.D.P.Z., ms. 471, f. 9r.

464 A.D.P.Z., ms. 338.

465 Registro de actos comunes del año 1636, A.D.P.Z., ms. 424, f. 54r-54v. 


\subsubsection{Signaturas e índices internos de registros}

Como hemos indicado, la acumulación documental y la riqueza informativa contenida en registros y escrituras propicia que se acometan tareas descriptivas e indicativas de su contenido. Junto a ellas, o derivadas de ellas, se encuentran las tareas de signatura de legajos y disposición de éstos, así como la indización de los registros en las primeras hojas como ayuda directa a la localización de los actos documentados.

Con respecto a la signatura dada a los legajos y registros del archivo del reino, éstos se disponían generalmente en torno a tres elementos clave para su localización: número de armario, bajo la abreviatura ALM. ${ }^{\circ}$; número de legajo, bajo la abreviatura LEG; año correspondiente al registro.

Junto a estas breves anotaciones de localización, todos los registros de actos comunes comenzaban con un índice de los actos contenidos, generalmente por orden alfabético. Sin embargo, la imprecisión terminológica es patente, al mezclar acciones con tipologías documentales concretas. En abril de 1694 José de Sagarra, asistente de Juan de Audina, responsable del índice de las cosas más notables sacadas de los actos comunes, indicaba esta circunstancia del trabajo de indización y resumen. Se ocupó de poner en los márgenes de los registros el asunto del que trataban, con el fin de ver rápidamente el contenido sin necesidad de leer todo el acto jurídico. Además, se ocupó de realizar los índices preliminares de dichos registros, poniendo por orden alfabético actos, materias y otros actos:

Y respecto de el pacto que se hayan de poner rúbricas en los registros de actos comunes de la diputación de sesenta años a esta parte y en los registros de la junta magna se ha executado assí, guardando el horden alfavético que en el dicho pacto se expresa, añadiendo el suplicante el margenar los actos que por omissión de los notarios estavan sin nota a las márgenes de que se originava aumentarse el trabajo al suplicante, precisándole a leer todos los actos para resumir la substancia de ellos y hazer verdadero reclamo a la matrícula en la qual, sin ver muchos de los actos de dichos registros se puede saver todo lo que en ellos se contiene y también se han hecho rúbricas a los registros que les faltava desde el año 1600 hasta 1634, en que empeçava la obligación del pacto de dicha concordia. ${ }^{466}$

466 Registro de actos comunes del año 1693, A.D.P.Z., ms. 601, f. 176v. Vid. apéndice documental, n. ${ }^{\circ}$. 



\section{LA CONSULTA DE LA DOCUMENTACIÓN DEL ARCHIVO}

El archivo es garantía de autoridad e instrumento de control, herramienta de gestión administrativa y fuente indispensable para la erudición histórica, sea ésta dirigida por los poderes institucionales o no. ${ }^{467} \mathrm{La}$ utilización e instrumentalización de los documentos de la Diputación del reino de Aragón para garantizar derechos, aportar pruebas documentales o argumentar la construcción historiográfica del propio reino fue también un hecho evidente. En definitiva, el archivo del reino se mantuvo al servicio simultáneo de las funciones de gobierno, administración interna y económica y de investigación histórica, como mostraremos en el capítulo siguiente.

El cumplimiento de estos fines obligó a establecer y regular unos modos de acceso y consulta de la documentación del archivo del reino de Aragón tanto por parte de los oficios y órganos del consistorio habilitados para ello como por particulares e individuos ajenos a la estructura orgánica de la institución que recurrían a la riqueza informativa custodiada por los diputados. Por consiguiente, en virtud de los interesados en examinar los documentos del reino, cabe dividir a los usuarios en dos categorías: internas, es decir, miembros directos del equipo de oficios y cargos dependientes de los diputados, y personas externas a la Diputación. Como parte indispensable del quehacer burocrático cotidiano, los integrantes del consistorio aragonés deben acceder a las series documentales para argumentar

467 Paul Delsalle (1998), pp. 152-153: «Usages et utilité des archives». 
decisiones que afectan tanto a la función política excelsa como a las pequeñas actividades cotidianas. En este sentido, la documentación se convierte en un recurso de primer orden para fundamentar la actuación de los diputados; pero también para facilitar la gestión administrativa de los asuntos encomendados. En cuanto a los modos de consulta, ésta puede realizarse a través de consultas directas, envíos documentales y certificaciones.

En términos generales, la consulta de la memoria escrita del reino casi siempre se desarrolló en la sede de la Diputación, puesto que se prohibía muy especialmente la salida de los registros fuera del propio palacio. Sin embargo, como veremos más adelante, los documentos podían traspasar las fronteras de dicho edificio ante una situación de urgente necesidad de registros y escrituras conservadas en el archivo. Generalmente estas salidas fueron motivadas por la insistencia de los brazos asistentes a Cortes o por peticiones del monarca.

Finalmente, también se analizará el valor de la custodia de los documentos como constante histórica e inherente a las funciones reservadas a los archivos del período histórico analizado. De hecho, Elio Lodolini acuña la expresión "Archivo secreto de la Edad Moderna" para incidir en esta característica definitoria de los depósitos de los siglos XVI al XVIII. La consultabilidad de los archivos se determina en función del permiso o denegación derivada de la titularidad del depósito. ${ }^{468} \mathrm{El}$ hecho de que el acceso fuera muy restringido y en ningún modo público, no exime del estudio de los usuarios reales del archivo en la Edad Moderna, con fines generalmente centrados en el recurso al archivo como medio para garantizar derechos documentalmente.

No obstante, y aunque para las líneas que siguen se analiza la petición y consulta de los documentos custodiados en el archivo del reino, también la Diputación mostró la necesidad de verificar datos y documentos albergados en otros depósitos. La falta de algunos registros de Cortes del reino motivó una consulta documental fechada a 30 de mayo de 1553 y que, dirigida al archivero del archivo real de Barcelona, verificaba la necesidad de reconocer los registros de las Cortes del reino que se encontraban en dicho depósito "para que se imprimiesen y publicasen

468 Elio Lodolini (1993), pp. 248-249. 
para la común utilidad de todos y entendiéndose en esto, háse visto que aquí faltan algunos registros destos tales procesos de Cortes y creyendo que podría ser que se hallasen en este archiu de Varcelona [sic] por ser tan antiguo $[\ldots] »{ }^{469}$

\subsection{Usuarios internos}

Los diputados constituyen el principal grupo de usuarios del archivo del reino. No sólo generan la documentación derivada de sus competencias de gobierno, sino que muchas de sus argumentaciones jurídicas y procedimentales se asientan sobre la firme consulta de los actos jurídicos documentados y custodiados en el archivo de la Diputación. Se consultan tipologías documentales para numerosas actividades que surgen en el cotidiano quehacer del consistorio aragonés. Los registros de entradas y salidas de escrituras, así como los registros de actos comunes, recogen numerosas noticias puntuales sobre la petición, hecha generalmente al secretario de la Diputación, de que entre en el archivo y proporcione los volúmenes a los diputados. En otras ocasiones, son ellos mismos quienes se personan en el archivo y alguno de los notarios de plantilla da fe de los documentos extraídos.

Una consulta normal se podía efectuar siguiendo el esquema del siguiente ejemplo, reproducido hasta la saciedad en la documentación generada por los diputados. En abril de 1661 los diputados mandaban al secretario Jerónimo de Naya que entregase los cabreos de vedas de panes y carnes: «Sus señorías hicieron mandamiento a Gerónimo de Naya, secretario del consistorio que entregue al señor don Diego Antonio de [ilegible], diputados, y comisario de viedas, dos procesillos de [viedas?] hechos a instancia de los señores diputados [...] el qual, satisfaciendo a dicho mandamiento, entregó a dicho señor diputado comisario los dichos dos procesos arriba mencionados y su señoría otorgó como diputado y comisario haverlos recivido de dicho señor, otorgó ápoca de ellos». ${ }^{470}$

469 A.C.A., Col. H. 1084. Publicado por María de los Dolores Mateu Ibars (1986), p. 419.

470 Registro de actos comunes del año 1660, A.D.P.Z., ms. 506, f. 497v. 
En otras ocasiones, los diputados consultan las series del archivo para resolver cuestiones de protocolo y ceremonial interno, habida cuenta de la enorme casuística desarrollada en el seno del palacio. ${ }^{471}$ Por tanto, innumerables fueron las ocasiones en que se pidieron los registros de actos comunes y otras tipologías para solventar una cuestión de preeminencia o de jerarquía con el fin de anotar cómo fue resuelta en el pasado. Un ejemplo de esta circunstancia la hallamos en junio de 1641, cuando "los señores diputados trataron de cómo se havían de asentar en la sala Real». A tal efecto "mandaron ver el registro de los actos comunes del año 1599 que hubo otra junta de brazos en la misma sala y en él consta que havían estado en la sala real en esta forma: los señores diputados todos juntos en forma de consistorio asentados, el señor obispo devaxo el Christo que está en dicha sala al lado del archiu y a la mano derecha los prelados, capitulares y luego la ciudad de Caragoza». ${ }^{472}$

Después de los diputados, uno de los principales elementos en todo el entramado de la administración económica del impuesto de generalidades lo constituyen el administrador y arrendador de dicho gravamen. Éstos se encuentran de igual modo sujetos a la memoria de los registros del reino y a la dinámica documental, representada sobre todo en la entrega de los libros negros o registros contables de dicho oficio.

Como se ha indicado en el apartado dedicado a la estructura orgánica de la Diputación, los inquisidores de cuentas se ocupan de verificar la adecuada contabilidad interna de la institución. En esta función, el recurso a la escritura y a la memoria contable se vislumbra con especial fuerza. Todo el proceso de revisión de cuentas (del administrador, del pagador de la gente de guerra, de los encargados de los bienes de la Diputación, etc.) requiere en muchas ocasiones de la consulta de los documentos necesarios para argumentar las decisiones. Para ello, el archivo del reino se abre con frecuencia para sacar y poner sobre la mesa cuantos registros y documentos sean solicitados por los contadores: «Si para pasar estas cuentas los contadores han de menester los libros de cuentas viejos y qualesquiere registros cabreos, consultas y libros de la hacienda del Reyno, se les an de entre-

471 Véase en general mi trabajo presentado al I Congreso Internacional de Emblemática: Diego Navarro Bonilla, «El protocolo y ceremonial de la Diputación del Reino de Aragón a través de sus fuentes documentales», en prensa.

472 Lorenzo Ibáñez de Aoiz, Ceremonial..., B.N.E., ms. 2922, f. 256r-257v. 
gar los detenedores de aquéllos». ${ }^{473} \mathrm{Y}$ en este sentido, numerosas fueron también las ocasiones en que los contadores solicitaron tipologías documentales para argumentar su trabajo con pruebas escritas. Por ejemplo, en junio de 1660 se abría el archivo y se entregaban varios libros negros (o registros de los administradores del general) a los contadores. ${ }^{474}$

En el procedimiento judicial seguido para tramitar los procesos de denunciación, inquisidores de procesos y judicantes actúan como incoadores y resolutores de dichos procesos. Por tanto, dentro de esta parcela judicial, la consulta documental es una práctica habitual y necesaria para el cotidiano quehacer burocrático. Velar por el correcto ejercicio de las competencias de los oficios vinculados a la corte del Justicia fue competencia de los inquisidores de procesos así como de los diecisiete judicantes, encargados de incoar — los primeros - y sentenciar — los segundos — los procesos de denunciación contra estos ministros judiciales. De nuevo la consulta documental, en este caso para desarrollar una función de fiscalización judicial, opera activamente en el seno de la Diputación. En abril de 1610, únicamente como ejemplo ilustrativo de una práctica común a lo largo de los años, los inquisidores de procesos, advertidos por sus propios notarios, pedían a los diputados la ordinaria consulta de procesos de denunciación ya finalizados pero necesarios para su trabajo jurídico. ${ }^{475}$

473 Lorenzo Ibáñez de Aoiz, Ceremonial..., B.U.Z., ms. 199, f. 64r.

474 Registro de actos comunes del año 1660, A.D.P.Z., ms. 506, f. 10r: «Sus señorías dixeron que para fin y efecto de sacar los libros negros para los señores contadores y mandaban se abriera el archivo y avierto aquél, mandaron sacar y se sacaron los libros negros de desde el año mil seyscientos quarenta y tres inclusive hasta el año de mil seyscientos cinquenta y siete inclusive menos el del año de mil seyscientos quarenta y nuebe que éste no se sacó; todos los quales dichos libros negros, dichos señores diputados los dieron y entregaron a dichos señores contadores y se quedaron con ellos para fin y efecto de pasar, ajustar las cuentas el presente año. Y hecho lo sobredicho, dichos señores diputados mandaron cerrar dicho archibo y se cerró».

475 Registro de actos comunes del año 1609, A.D.P.Z., ms. 314, f. 161v-162r: «Los señores diputados del presente reyno, a cuyo cargo están las llaves del archio del presente reyno, juntamente con mi, Juan Fraylea, notario, presentes los testigos avaxo nombrados para sacar del archio del presente reyno los procesos que pedían los inquisidores de las denunciaciones y hazer lo que más conviniese, subieron y subimos al dicho archio y reconocido por mi dicho notario, las puertas de aquél allé aquéllas bien cerradas y entregadas por dichos señores diputados y con dicho notario, las llaves de aquél a Juan Gerónimo Muniessa, portero, aquel abrió dicha puerta y de dos calaxes de dicho archio fueron sacados los procesos infraescriptos: [Tres procesos de denuncicación] Todos los quales dichos procesos fueron sacados de dicho archio y entregados a los señores don Henrique de Cas- 
Otros ejemplos de la consulta de documentos del reino por parte de los inquisidores de procesos y sus notarios se evidencian en pleno siglo XVII, como el documentado en abril de 1634, cuando se «Mandaron sacar y en effecto se sacaron tres procesos de denunciaciones [...] y se mandaron entregar a los señores inquisidores de procesos a cuya instancia se sacaron de dicho archivo». ${ }^{476}$ En cuanto a los judicantes, también se documentan sus consultas documentales. El día 12 de junio de 1576, los judicantes necesitaban consultar varios procesos de denunciación para proseguir la causa contra micer Jerónimo de Esplugas. Ante la petición formal de consultar los documentos depositados en el archivo del reino, los diputados abrieron «la puerta de dicho archiu con quatro llaves diversas y aquellas hubrieron assí sus señorías como yo dicho notario y los testigos infraescriptos y [en blanco] vieja, notario substituto de los dichos seynores inquisidores entramos en dicho archiu y de diversos caxones que en dicho archiu había, fueron sacaos los procesos intitulados y recitados en dicho cartel de compulsa y que ellos y cada uno dellos fueron entregados $[. .] »$.

Dentro de la compleja maquinaria administrativa de la Diputación, los abogados del reino ocupan un lugar preeminente. De hecho, son ellos los que con su sabiduría jurídica y consejo legal aportan datos de inestimable ayuda para la gestión de los diputados. Generalmente, la respuesta a las peticiones de consejo jurídico expresadas por los diputados a los abogados del reino se materializan documentalmente en la consulta como tipología archivística.

Para resolver dicha petición de información, la nómina de abogados necesita cotejar datos, consultar registros y acumular saber y práctica administrativa para fundamentar sus respuestas. A tal efecto, también los abogados se sirvieron del enorme caudal informativo proporcionado por el archivo del reino para cumplir con su cometido de consejeros jurídicos. En agosto de 1619, el abogado Balaguer hacía llegar a los diputados un

tro y Cervellón, canónigo, don Baltasar de Gurrea y Cerdán, señor del Castellar y micer Juan Miguel Lonzina, inquisidores de las denunciaciones en el presente año que presente estavan y sus señorías los otorgaron haver recivido y prometieron y se obligaron restituyrlos, hechos y concluydos los procesos de denunciaciones que de presente se tratan a los dichos señores diputados para que los buelban al dicho archio".

476 Registro de actos comunes del año 1633, A.D.P.Z., ms. 407, f. 211r-211v.

477 Registro de actos comunes del año 1576, A.D.P.Z., ms. 231, f. 12v y ss. 
memorial donde indicaba la consulta realizada a los registros del reino: «Illustrísimos señores. El doctor Jusepe Valaguer, dice que del año 1590 hasta de presente, por haver sido algunos años advogado del reyno ordinario y extraordinario a trabajado en 29 años unos comentarios a los actos de corte con algún trabajo que en ellos a puesto y reconocido papeles y escrituras del archiu en gran beneficio público y para tener los señores diputados muy clara noticia de su jurisdictión y preheminencias del consistorio y a tenido y tiene, resolvieron de imprimillos [... ${ }_{\Perp}{ }^{478}$

Y en 1673 los diputados del reino "para fin y efecto de haverse de sacar del archivo unos processos para exemplar a los advogados del reyno, mandaron abrir dicho archivo, el qual se halló bien y lealmente cerrado y aquél abierto, haviéndose sacado de él diversos procesos para que sirvieran de exemplares a los advogados del presente reyno en el modo de proceder en tal causa y processo pendiente por dicho consistorio y escribanía de la diputación a instancia del illustre don Francisco Sanz de Cortes, marqués de Villaberde, contra Juan de Latorre, super civilis de mandamiento de dichos señores diputados el dicho archivo fue cerrado y se entregaron las llaves a las personas en cuyo poder estaban». ${ }^{479}$ En definitiva, el archivo y las escrituras del reino constituyeron unos recursos indispensables en todo el entramado burocrático de los oficios de la Diputación.

La fundamentación histórica oficial del reino descansa sobre el trabajo erudito desarrollado por la nómina de cronistas, razón por la cual necesitaron acceder a la documentación original custodiada en numerosos archivos y bibliotecas. A pesar de los necesarios desplazamientos a otros archivos, el archivo del reino de Aragón reunía un incesante cúmulo de noticias que, naturalmente, los cronistas consultaron con frecuencia. En este sentido, el método de trabajo historiográfico se vio favorecido por la habilitación de una sala en el palacio de la Diputación aragonesa para desarrollar el trabajo intelectual en la misma sede del reino, muy próxima a la del archivo.

El «aposento» del cronista, como se conocía, estaba compuesto por un parco mobiliario. Una mesa grande aparecía repleta de registros, papeles y escrituras, muchas de ellas copias de los originales custodiados en el archi-

478 Registro de actos comunes del año 1619, A.D.P.Z., ms. 353, f. 59v.

479 Registro de actos comunes del año 1672, A.D.P.Z., ms. 542, f. 108r-108v. 
vo. Así, cuando el hermano del doctor Juan Francisco Andrés de Uztarroz, noveno cronista oficial, hacía en marzo de 1654 una «Memoria de todo lo que se ha hallado en el aposento de la diputación que tenía el doctor Juan Francisco Andrés, mi hermano, cronista del Reyno de Aragón, para ver los papeles que sacava del archivo», ${ }^{480}$ sobre aquella mesa de pino se hallaron «diez y nueve legajos de cartas y un libro sin cubiertas de lo mesmo, todo en folio». ${ }^{481}$ Además, cada año el cronista recibía una pequeña cantidad en concepto de ayuda para adquirir material de escritorio, pero también, y como dato curioso, para comprar el carbón con que calentar la estancia. ${ }^{482}$ La consulta del archivo por los cronistas constituyó una práctica habitual, como demuestran las incontables incursiones para anotar, recoger y cotejar datos de registros custodiados en el archivo, de las que dan cuenta los registros de actos comunes. ${ }^{483}$

Sin embargo, no siempre la petición de consulta tenía efecto. Así, en marzo de 1643 era el cronista Francisco de Gurrea quien solicitaba sacar del archivo «los fueros de Sobrarbe y el índice de las cosas que hay en dicho archivo y los dichos señores diputados mandaron entregar dichos registros y demás papeles excepto los dos registros de los años mil quinientos y nobenta y nobenta y uno a los doctores don Francisco de Gurrea, coronista del presente Reyno». ${ }^{484}$

Asimismo, a pesar de que la consulta documental se efectuaba generalmente en el interior del palacio de la Diputación, ocasiones hubo en que el cronista sacó documentación del archivo con destino a su propia casa, desa-

480 Registro de actos comunes del año 1653, A.D.P.Z., ms. 479, f. 559r.

481 Publicado en Diego Navarro Bonilla (1999c).

482 R.A.H., ms. 9/548, f. 432r: «Los diputados del Reino de Aragón a Blas Asensio Monterde, nuestro portero ordinario y administrador de las expensas menudas, decimos, dé y pague al doctor Diego José Dormer, nuestro coronista, tres libras y quatro sueldos jaqueses que se le acostumbran dar cada año por el carbón que gasta en el aposento de su oficio, y más ocho libras jaquesas que también se le acostumbran dar para quatro resmas de papel, plumas y tinta [...] a 14 de deciembre de 1689 ».

483 Sirva como ejemplo de los innumerables testimonios similares la consulta de Porter y Casanate en diciembre de 1669 (Registro de actos comunes del año 1669, A.D.P.Z., ms. 533, f. 131r): «Mandaron subir al archivo del presente Reyno para fin y efecto de sacar de él diversos registros y papeles y entregar aquellos a don Joseph Porter, coronista del presente Reyno para que los vea; el qual dicho archivo fue abierto y dél se sacaron dichos registros y papeles, los quales fueron entregados al dicho don Joseph Porter, coronista sobredicho, que presente estaba».

484 Registro de actos comunes del año 1642, A.D.P.Z., ms. 443, f. $156 \mathrm{v}$. 
rrollando así un préstamo ocasional, puntual y muy poco habitual. Por ejemplo, en 1618 los diputados consultaban a los abogados «si darán permiso para que el coronista se lleve a casa ciertos registros de que necessita. Responden se interponga consulta a la corte [del Justicia de Aragón]».

Una vez suprimido el ordenamiento jurídico aragonés, los historiadores aragoneses del siglo XVIII se sirvieron en mayor o menor medida de la riqueza documental depositada en los archivos del palacio. Esta riqueza proporcionada por los registros del archivo del reino y de la bailía y maestre racional también fue aprovechada durante la segunda mitad del siglo XVIII con fines de investigación histórica, como durante los siglos anteriores. ${ }^{485}$ Los datos suministrados por las series de naturaleza económica y fiscal derivadas de la gestión administrativa de la hacienda del reino proporcionaron valiosa información de apoyo para la notable investigación aragonesa de finales del XVIII. ${ }^{486}$

De entre los eruditos que accedieron en el transcurso de sus investigaciones a alguno de los cuatro archivos situados en el palacio de la Real Audiencia, sobresalen el padre Joaquín Traggia y, especialmente, Ignacio Jordán de Asso. Del primero subrayamos las indicaciones que él mismo consignó en el prólogo a la Descripción de los pueblos del partido de Daroca. Allí consignaba su paso por el archivo del reino: «Se verá no obstante, por las noticias que se incluyen, cómo he procurado consultar la Historia, el Archivo antiguo de la Contaduría General del Reino y de los antiguos diputados de sus cuatro brazos sobre la población y los particulares del Partido [...]. ${ }^{487}$ Con respecto al segundo, el autor de la Economía Política registró la situación del archivo del reino de Aragón cuando consultó los

\footnotetext{
485 Diego Navarro Bonilla (2000a).

486 Vid. en general Antonio de Gregorio Rocasolano (1923), pp. 22 y ss. Juan Jaime López González (1977).

487 J. Traggia, Descripción geográfica de la Capital y todos los pueblos del partido y comunidad de Daroca, Cervera del Río Alhama, 1790. El escolapio Joaquín Traggia mantuvo cordial relación con el archivero de ambos depósitos, don Felipe Fernández de Arias: R.A.H., ms. 9/5219: «En la misma tarde del 16 [mayo de 1792], don Felipe [Fernández de Arias] hizo relación al Padre Traggia del estado de aquel archivo, que estaba arreglando i formando su índice e historia. Franqueóle lo que tenía puesto en limpio, ofrecióle lo demás a fin de que enterado del contenido, viera si le acomodaba u no ver algún instrumento [...] Este archivo [del Reino de Aragón] está a cargo de don Felipe Fernández de Arias, como el de la Bailía i habiéndomelo franqueado como el otro [...] empecé a visitarlo el día 24 de mayo de 1792».
} 
fondos allí albergados con el fin de fundamentar documentalmente sus trabajos de historia económica de Aragón, de los cuales elabora una crítica negativa. ${ }^{488}$

Por su parte, el benedictino fray Manuel Abbad y Lasierra (17291806), infatigable visitador de archivos y librerías, también consultó los fondos del antiguo archivo del reino de Aragón para cimentar sus investigaciones sobre la antigüedad del monasterio de San Juan de la Peña. El día 9 de diciembre de 1771 se documenta una petición de acceso a dicho depósito. ${ }^{489}$

Junto a ellos se deben citar los nombres de Abella y Lezaun y Tornos. Del primero sabemos que accedió al archivo del reino para realizar la «Copia del repartimiento de sisas que se halla en el archivo de la Diputación antigua de Aragón intitulado: Lo libro del conto de las sisas indutas del Reyno de Aragón, por tiempo de dos años, que empiezan en el de 1489 y acaba en el de $1491 »{ }^{490}$ De don Tomás Fermín de Lezaun y Tor-

488 Ignacio Jordán de Asso (1798), en la edición de 1983: «En su archivo se conservaban un gran cúmulo de libros de las Generalidades antiguas. La insuficiencia de los libros de Aduanas para apreciar el comercio nacional está reconocida de muchos escritores económicos; a que se allega también la desconformidad observada entre los libros de diferentes países, que comercian recíprocamente [...] Aunque en el archivo de la Diputación se conserva un gran cúmulo de libros de las Generalidades antiguas pertenecientes a varios años, sirven poco o nada para establecer la balanza aparente de nuestro comercio; porque en casi todos los Registros están confundidas las partidas de entrada con las de salida y otros, que llevan cuenta y razón separada de los ingresos y exportaciones, comprenden solamente algunas tablas particulares de las muchas que tenía distribuidas el General en las Ciudades y Villas principales del Reino». Sobre el autor y su obra es fundamental la consulta del trabajo de Antonio Peiró (1998), pp. 89-93, donde se analiza el trabajo de campo desarrollado por Asso en sus consultas de la documentación custodiada en los archivos de la antigua Diputación del reino y en el de la bailía y maestre racional de Aragón.

489 A.D.P.Z., leg. 755-14: «Daba noticia de lo referido, de que varios documentos del archivo de San Juan de la Peña se hallaban en el archivo de la Real Antigua Diputación de esta Corona. Que para solidar assí el manuscrito de que dio noticia a Su Majestad como otras escrituras que ha encontrado importantes al honor de la succesión real, necesita ver (sin extraerlos aquellos privilegios o escritos que se remitieron del Archivo de San Juan de la Peña a instancia de la Diputación de este Reyno y consta se hallan en su Archivo y un árbol genealógico de los señores reyes de Aragón muy antiguo que está rollado en un pergamino [...] A vuestra señoría supplica quiera mandar a el Archivero maior de la Real Diputación le permita ver todos los documentos, privilegios y escrituras que pertenezcan o guarden [?] relación con el archivo de San Juan de la Peña, los que sean útiles a comprobar el Reyno de Sobrarbe y Ribagorza y el árbol genealógico de los señores reyes de Aragón que se halla en dicho Real Archivo de la Diputación, de que recibirá favor».

490 R.A.H., ms. 9/5194. 
nos, hijo del archivero Pedro Lezaun, conocemos que buena parte de los resultados de sus investigaciones partieron de las consultas frecuentes efectuadas al archivo de la antigua Diputación del reino de Aragón. ${ }^{491}$

Como miembros de la corte del Justicia de Aragón, ubicada en el mismo edificio de la Diputación, los lugartenientes del Justicia también solicitaron con cierta frecuencia la consulta de documentos diversos, casi siempre con la motivación expresada con cierta ambigüedad "para ciertos fines y efectos». Como muestra, rescatamos la petición de Miguel Tomás Secanilla, lugarteniente en agosto de 1633, a quien le «convenía sacar del libro negro de las quentas que se an passado del año mil seyscientos treynta y dos un encaute que entre dichos se hizieron con consulta y respuesta della, et yo, dicho notario, cumpliendo con la obligación de mi officio, instado y requerido por el dicho doctor Miguel Tomás Secanilla, saqué de dicho libro que su principio dél comiença: mil seyscientos treynta y dos, libro primero del primer arrendamiento y administración de los drechos de las generalidades y cossas pertenezientes al reyno de Aragón». ${ }^{492}$

\subsection{Usuarios externos}

No existen datos de que los monarcas mandasen consultar el archivo del reino con excesiva frecuencia. Sin embargo, ante acontecimientos tan graves como los sucedidos en la rebelión de 1591, Felipe II no dudó en ordenar escudriñar los registros de la Diputación y conocer lo anotado por el consistorio aragonés con el fin de contrastar datos y proceder contra los culpables con mayor rigor. De nuevo el archivo del reino hacía honor a su calidad y nivel proporcionando, muy a pesar de los propios diputados, información para ejercer tareas represivas por parte del «prudente». El día 19 de febrero de 1592 se presentó en la Diputación don Miguel de Lanz, senador de Milán del Consejo de Castilla, diciendo «que convenía a su real servicio para las cosas sucedidas en el Reino de Aragón». Felipe II le había comisionado con el fin de «ver y reconocer todos los rexistros, actos, pape-

491 Miguel Gómez Uriel (1884-1886) ofrece una lista de sus trabajos fundamentados en la documentación del reino, gran parte de ella de carácter genealógico y nobiliario. Ver además Miguel Ángel Castán y Alegre (1998).

492 Registro de actos comunes del año 1633, A.D.P.Z., ms. 407, f. 105 r. 
les y escrituras que tienen su poder desde el $1 .^{\circ}$ de junio del año próximo pasado de 1591, hasta el presente día de oy y año arriba calendado; y los dichos señores diputados mandaron a mi, dicho notario, mostrase aquellas que se hallan en mi poder». Acto seguido, el notario extracto de la Diputación, Diego de Miedes, accedió a mostrar la documentación requerida:

Mostré bien y fielmente todos los rexistros, procesos, cartas, provisiones, papeles y escrituras que en mi poder tenía y me hallaba y vistas cartas y otros papeles particulares que estaban en dos cajones que presenció el dicho comisario, sacó treinta y quatro cartas y quarenta y cinco papeles particulares, que en todos son setenta y nueve numerados y rubricados de mano de mi dicho notario, los quales dijo el señor comisario que al servicio de Su Majestad conbenía quedasen en su poder, los quales prometió restituir a este consistorio como haya cumplido lo que conbiene a la justicia y así mismo vio y sacó diez y seis procesos y una oja rubricada por mano de dicho comisario, para que yo, dicho notario le dé copia auténtica de ello mismo, y así mismo queda en poder de mi dicho notario, un rexistro de los actos comunes en el qual ha señalado dicho señor comisario tiene actos de los quales me ha ordenado y mandado expresamente saque copia auténtica de ellos en forma que haga juicio, lo qual he hecho yo, dicho Diego de Miedes, notario. ${ }^{493}$

Días después (22 de febrero) se volvía a requerir la apertura del archivo por parte del escribano de mandamiento Pedro Navarro, con comisión regia para «el conocimiento de las sediciones en Zaragoza, para las averiguaciones de los culpados». A tal efecto se pidieron «los actos Comunes de la Diputación de 1591 de $1 .^{\circ}$ de junio de dicho año, hasta 19 de diziembre de el otro registro, cartas misivas, provisiones y consultas de la Diputación de 1591 y otros varios registros y procesos concernientes a las cosas de Antonio Pérez, a la salida del exército del Reyno contra el de Su Magestad, a los alborotos y otros que por menor se refieren en el acto». ${ }^{494} \mathrm{El}$ objetivo de dicha consulta no albergaba ninguna duda acerca del valioso recurso que constituían las escrituras custodiadas en el archivo del reino, utilizadas en esta ocasión precisamente para depurar las responsabilidades habidas durante la rebelión:

Y de la comissión que se a despachado por el Rey Nuestro Señor al dotor Lanz, senador de Milán, para el conocimiento de las sediciones hechas en

493 Tomás Fermín de Lezaun y Tornos, Apuntaciones históricas..., B.N.E., ms. 9823, f. $127 \mathrm{v}$.

494 Ibídem, f. 129r. 
Çaragoça y en nombre de su Magestad y por orden del dicho señor comissario dixo que para el buen effeto de su comisión y para la averiguación de los culpados en aquello havía menester los registros de la Diputación que en el diez y noveno día del presente mes havía visto y reconocido y assí pidió a dicho notario que los truxesse y se los entregasse y el dicho Diego de Miedes dixo que los registros del sobredicho día diez y noveno día presentes eran los que allí tenía y mostró a dicho señor comissario y sobre una mesa juntamente con otros processillos y escrituras que allí estavan [...] tomava y tomó dichos registros, processos y escrituras y los llevó consigo para entregar al dicho señor senador. $^{495}$

Como epílogo de las alteraciones de 1591, las Cortes de Tarazona de 1592 se contemplaban como la culminación jurídica de los desmanes del año anterior y el intento por dejar las cosas en su sitio. En dicho año se volvió a solicitar documentación del archivo del reino por parte de Felipe II, quien instaba a los diputados a entregarle registros necesarios para la celebración de las Cortes:

Diputados: para las cortes que he convocado y he de celebrar a los desse Reyno en la ciudad de Taraçona, serán menester algunos papeles, escrituras y exemplares tocantes a estas materias de los que huviere archivados en el archivo dessa Diputación; y assí os encargo y mando que déys orden a la persona a cuyo cargo estuviere el dicho archivo que saque dél todo lo que es necesario de copiar o originales como os lo escriviere don Miguel Climente, nuestro protonotario, embiándole a sus manos los dichos papeles con toda brevedad y diligencia, dándole entero crédito en lo que de mi parte os avisare sobre estas cosas, que en ello me serviréys mucho. Dattum en Madrid a seys de abril MDXCII. Yo el rey. ${ }^{496}$

No finalizarían aquí las peticiones de Felipe II, ${ }^{497}$ quien no dudó en implicar al lugarteniente del justicia del reino, micer Batista de Lanuza, al pedirle que escribiese a los diputados solicitando varios registros, que había de conducir él mismo hasta Tarazona:

Aquí tengo neçesidad de todos los demás registros que vuestras mercedes tienen en su archiu para cosas que se an ofrecido y assí reçibir [?] que en lle-

495 Registro de actos comunes del año 1591, A.D.P.Z., ms. 261, f. 22r-23v.

496 Ibídem, f. 90 y ss.

497 Ibídem, f. 89r-92v: Mayo de 1592: «Los quales dixeron que atendido que el día de ayer les havían sido dadas dos cartas de la magestad del rey nuestro señor, por manos del Illustre micer Martín Batista de Lanuça, regente el officio de Justicia de Aragón, firmadas de su real mano, y dichos señores dipputados, dixeron haber respondido que se offrecían 
gando ésta, vuestras mercedes los manden sacar y librar al que está, que es Hierónimo Pérez, portero de mi corte que ya lleba poder mio para atorgarlos haver resçibido, porque an de llegar aquí para el viernes que viene y esto sea sin falta porque este mensajero no va para otra cosa. Que nuestro Señor Guarde a vuestras señorías como puede, de Taraçona a 26 de mayo de 1592. Supplico a vuestras mercedes me hagan la merced que digo, y me manden en su servicio. Las cortes se prorrogaron para el sábado y se caminará mucho, pues ya el señor arçobispo llegó ayer a Beruela. Micer Baptista de Lanuza.

El 6 de octubre de 1623 se documenta una petición inusual en el curso administrativo de la institución. Inquisidores del Santo Oficio solicitan a Pedro López de Quinto, secretario y a la vez familiar del Santo Oficio, la matrícula de los insaculados en los oficios del reino correspondiente al año $1536 .{ }^{498} \mathrm{La}$ solemnidad de los peticionarios y la gravedad del caso obligaron a Pedro López a consultar necesariamente con los diputados acerca de la conveniencia o no de dejar consultar dicha documentación. Los diputados, conscientes de la dificultad jurídica planteada, resolvieron «que considerando el caso arduo y dificultoso en tal demanda, reconocieron los actos de corte y haviendo tenido sobre ello maduro acuerdo, se le dixo a Pedro López que pues hasta entonzes no havía recado para el consistorio, no corría obligación de responder a su nombre, sino que en el suyo dixese a aquellos señores que havía dicho al consistorio lo que le havían mandado y que havía hallado una muy grande disposición en los áni-

prestos y aparejados cumplir lo que su magestad mandava por sus reales cartas y assi mesmo dixeron dichos señores dipputados que dicho micer Batista les había dicho que se había de partir el día de mañana, que se quenta a ocho días del presente mes para la ciudad de Tarazona y que tenía necessidad de llebar consigo dichos registros para berles y reconoscerles para cosas tocantes al servicio de su magestad y bien deste reyno; que paresciendo a dichos señores dipputados que dichos registros yrían y estarían debaxo la custodia del escrivano principal de la dipputación, como de presente los tiene y attendido que dicho Miguel López, escribano principal de la dipputación está absente de la dicha ciudad, mandaron a Jerónimo de Oliba, substituto de dicho Miguel López que sacasse de dicho archiu los dichos registros y fuese con ellos a la ciudad de Tarazona y allí los tubiesse en su poder, custodia y guardia y aquéllos mostrase a dicho micer Batista, siempre y quando los quisiesse ber y sacar dellos todo lo que combiniere al servicio de su magestad y bien del reyno. El qual dicho Gerónimo de Oliba, se ofresció presto y aparejado de hacer y con efecto cumplir lo que por dichos señores dipputados le era mandado».

498 En 1615, Pedro López, secretario, archivero y alcaide de la Diputación, fue obligado a renunciar a su empleo por haber descuidado la vigilancia del archivo y las escribanías del Justicia, al entregar irregularmente las llaves de dicho depósito al lugarteniente de alcaide Lorenzo Ibáñez de Aoiz. Cf. Registro de actos comunes del año 1614, A.D.P.Z., ms. 334, f. 260v-263r. 
mos de los diputados de serbir y dar gusto a aquel santo tribunal; pero que hallando el acto de corte tan apretado, dificultaban mucho hazer lo que se pidía».

Al día siguiente se presentaron dos secretarios del tribunal insistiendo en su petición. Frente a ello, los diputados accedieron a permitir la consulta de dicha matrícula, pero haciendo constar que se efectuase en «su escrivanía que está sitiada dentro la Diputación, adonde con asistencia de Juan Luys Fontoba, notario deste año de la Diputación, la vieron y reconocieron dichos secretarios de la inquisición, de lo qual hicieron relaçión el notario y secretario de la Diputación y volvió Pedro López la matrícula a los diputados, de que resolvieron dichos señores que era justo quedar asentada en este libro esta memoria así para dar cuenta del modo con que procedieron en esta acción, en la exacción de sus officios y para que en lo venidero conste de la verdad, lo qual fue hecho a 7 de octubre de 1623». ${ }^{499}$

El archivo, como custodio de documentos públicos, constituye la garantía documental de numerosos actos jurídicos en los que intervienen instituciones y particulares y de los que se desprenden consecuencias legales que afectan a numerosos individuos. Conocemos con precisión las peticiones de copias solicitadas al archivo de Simancas durante la Edad Moderna. Como indica Rodríguez de Diego, "El motivo siempre es el mismo: la pérdida de la escritura, garantía de la merced o privilegio, obligaba a solicitar una copia "para guarda de su derecho". La concepción del archivo como poder radica precisamente ahí, en que la garantía del derecho del súbdito dependía de la voluntad del monarca a través de un despacho expedido por el órgano institucional $[\ldots] » .{ }^{500}$

El caso del archivo del reino, salvando las lógicas distancias con la maquinaria archivística simanquina, no escapa a esta consideración común a los archivos de la Edad Moderna. Se acude al lugar donde se recoge la memoria de los actos económicos, de gobierno o judiciales para conseguir un testimonio probatorio que aportar en un procedimiento administrativo o en un proceso judicial, para garantizar, en definitiva, un acto jurídico mediante el testimonio escrito, algo que a fines del siglo XVI ya se consignaba como práctica frecuente: «Y como se hayan ofrecido y de cada día se offrecen haver de

499 Lorenzo Ibáñez de Aoiz, Ceremonial..., B.N.E., ms. 2922, f. 234v-236r.

500 J. L. Rodríguez de Diego (1998b). 
sacar y piden muchas personas actos y muchas escrituras de dichos registros y archiu, sacados en pública forma signados y fe hacientes».

La concesión de un hábito de una orden militar requiere un proceso administrativo complejo, necesitado de pruebas, garantías e instrumentos documentales de diversa naturaleza. Existen varios ejemplos documentados. Consciente de que el archivo del reino custodia el instrumento jurídico que pueda favorecer su causa, el procurador de don Manuel Celaya acudía allí en noviembre de 1689 para consultar registros y matrículas con el fin de probar un hábito, razón por la cual «Suplicó a dichos illustrísimos señores dipputados fuesen sus señorías servidos de mandar se le mostrasen las matrículas y registros antiguos del consistorio para veer y reconocer en ellos si los ascendientes del dicho don Manuel Celaya, su principal, havían estado insaculados en los oficios honoríficos del reyno por necesitar de semejante aberiguación para la conclusión de sus pruebas de un hábito y para otros fines». Los diputados accedieron a la petición, y un diputado y el secretario subieron al archivo, de donde se sacaron varios registros de matrículas de insaculados. El resultado fue positivo para el solicitante: «y resulta que en las cortes del año mil seiscientos veinte y seis fue inseculado en dipputado don Juan Bautista Jerónimo de Orera con teruelo vitalicio y assí mismo en el mes de marzo de el año mil seiscientos treinta y dos fue también ynsaculado en dipputado el doctor don Dionisio Ambel de Teruel en vacante y por muerte de Francisco Gerónimo de Palomar [...]». ${ }^{501}$ Otras peticiones de personas particulares se documentaron, como la fechada en 1617 de don Antonio Manrique de Lara, quien suplicó que «se saque del archivo un proceso actitado a su instancia contra micer Martínez del Villar, lugarteniente, sobre desinsaculación». ${ }^{502}$

Tres años después, el vicario de Torres, barrio de Calatayud, «dio un memorial pide y supplica por él que le conviene ver un processo del año 1582 que se llebó en el consistorio en el qual ay ciertas escripturas necessarias a su benefficio». A esta petición particular, los diputados respondieron que dichos registros «se sacarían en la primera ocasión que se abriesse el archibo». ${ }^{503}$ Por su parte, en 1637 el zaragozano Sebastián de Luna y

501 Registro de actos comunes del año 1689, A.D.P.Z., ms. 396, f. 28v-29v.

502 Esta solicitud se encontraba en el armario 83, dentro de los procesos de súplicas.

503 Registro de actos comunes del año 1619, A.D.P.Z., ms. 374, f. 85r. 
Espés «pidió y suplicó a sus señorías que como archiveros y detenedores que son de los processos de denunciación recónditos en el archivo del Reyno que está en la sala real, mandassen sus señorías despachar unas letras narrativas de lo que se contiene en los procesos de denunciación hechos a instancia de Juan de Montañana, mercader de Valencia», con el fin de que estas letras narrativas puedan «valer fe en la corte del señor Justicia de Aragón, en un proceso que en ella pende intitulado procesus Lupicini de Felipe Lupecini Mercatoris, Cesarauguste, super apprehensione y sus señorías las concedieron y mandaron despachar». ${ }^{504} \mathrm{Y}$ en julio de 1660, el procurador de Lucas Martínez «suplicó a dichos señores diputados sean servidos mandar se saquen del archivo unos registros que dará por memoria para sacar unas ápocas, etc.». 505

De este modo, los interesados en acceder a la documentación del reino lo hacen de dos maneras: a través de una inspección directa o a través de la expedición de copias auténticas. En teoría, el archivero es un notario capacitado para extender copias fehacientes de aquellos documentos no sometidos al secreto institucional. Como consecuencia del incremento de la petición de documentos y copias de originales conservados en el archivo del reino, se arbitraron algunas medidas, como la habilitación de un notario de Zaragoza que realizase copias fehacientes para atender la demanda. En octubre de 1599, los diputados esgrimieron el viejo fuero que hacía referencia a la obligación de tener custodiados los registros, procesos y escrituras en el archivo del reino, que para entonces estaba a cargo de Pedro López, secretario, escribano principal y archivero. Ante la gran demanda de copias auténticas, los diputados nombraron al notario Miguel Arcentín para «sacar en pública forma» las copias solicitadas de los documentos custodiados en el archivo, habida cuenta de que Pedro López no lo era todavía: «dicho Pedro López, archivero y escribano principal no ha podido ni puede sacar ni signar, de suerte y de manera que hagan fe en juizio por no ser como no es aún notario y como no puede ni debe hazer ningún perjuizio ni daño a nadie, deteniéndoles y no dándoles los actos que piden». 506

504 Registro de actos comunes del año 1636, A.D.P.Z., ms. 424, f. 136r.

505 Registro de actos comunes del año 1660, A.D.P.Z., ms. 506, f. 75v.

506 Registro de actos comunes de 1599, A.D.P.Z., ms. 286, f. 114r-115v: «y habiendo como han llegado algunos con quexas que no se les daban los actos que pidían. [...] nombramos para sacar en pública forma signadas y fehacientes y de la manera que conviniere qualesquiere actos de qualesquiere registros, letras, deliberaciones y otras qualesquie- 
En otras ocasiones, la necesidad de consultar los registros del reino se vio acompañada de una violencia intolerable en la sede política de Aragón: que con ocasión de que unos consejeros del juez de la ciudad, el zalmedina de Zaragoza, necesitaron en 1644 inventariar unas escrituras custodiadas en el archivo, privilegiadas por vía de firma concedida a los diputados. Se trataba de un proceso que no podía aplicarse a las escrituras del archivo del reino, por haber obtenido una firma garantizando la inmunidad de su memoria escrita. No obstante, los oficiales del zalmedina no consintieron ni aceptaron la firma mostrada. Su airada reacción provocó que descerrajasen «la puerta del consistorio derribando la cerraja y hechándola en tierra. Por lo qual consultan dichos señores diputados si pueden y deben dar un apellido criminal a los que lo executaron y / a los infractores de firma y oficiales delinquentes en sus officios / aconsejaron y dichos señores advogados y respondieron y aconsejaron lo siguiente: que según lo referido en la consulta pueden y deben acusarles en la Corte del Señor Justicia de Aragón». ${ }^{507}$

\subsection{Modos de consulta}

\subsubsection{Certificaciones expedidas por el archivero}

Las certificaciones expedidas por el archivero del reino de Aragón comprendían numerosos asuntos que afectaban, como queda dicho, tanto a particulares como a órganos institucionales. Así, entre las varias certificaciones conservadas hasta nuestros días, deben citarse las minutas de certificaciones que expidió Pedro Felipe de Lezaun acerca de la compra de las casas de Nicolás Escorihuela por parte de los diputados del reino en 1591, por un coste de 14250 escudos. ${ }^{508}$ En un documento fechado el 22 de junio de 1768 , se encuentra la minuta realizada por el mismo archivero

re escripturas, processos y estos que estén custodidos y guardados y recónditos en el dich archiu de la dipputtación etc., a Miguel Arcentín, notario habitante en la ciudad de Çaragoça y substituto que es de Domingo Azaylla, notario extracto de la Dipputación [...] Y quanto sea necessario le creamos y nombramos en comissario de dichos registros y escripturas de la Dipputación o archiu de aquella para que pueda aquellas sacar en pública forma, signar y a la parte librar como dicho es, exigiendo y cobrando de aquella los drechos que según el estillo y ordinaçiones de la Diputación puede y debe cobrar. Dándole asi mismo acerca esto todo el poder bastante y cumplido que dar y atribuyr le podemos».

507 Registro de actos comunes del año 1644, A.D.P.Z., ms. 449, f. $45 \mathrm{v}$.

508 A.D.P.Z., leg. 755-1. 
acerca de otra certificación. ${ }^{509}$ En 1772, Pedro Felipe de Lezaun expidió certificación acerca del priorato de Santa María la Mayor. ${ }^{510}$ Un año después se documenta la certificación del archivero sobre el recuento de los bienes del conde de Sástago. ${ }^{511}$ Otra certificación fechada en 1778 se refería a diferentes asuntos relativos a la fundación de la iglesia de San Cayetano y sus antecedentes. ${ }^{512}$

Sobre esta última certificación conocemos algunos datos administrativos que pueden servir de orientación para comprender el trámite seguido para la expedición de estos documentos. Así, la solicitud de los interesados, en este caso el clérigo de Santa Isabel, vulgo San Cayetano, pedía dicha certificación en los siguientes términos:

El prepósito y Padres Clérigos Reglares de San Cayetano de la Real Casa de Santa Ysabel de esta ciudad, con su maior veneración dicen: que para ciertos fines, les conviene extraher del archibo de la antigua Diputación de este Reyno varias noticias que se hallan en sus libros. En esta atención; A Vuestra S., rendidamente, supplican se digne mandar, que por Don Pedro Felipe de Lezaun, a cuio cargo está el citado archibo, se les dé las certificaciones que necessitan, que assí lo expresan de la notoria justificación de V.S. Don Juan Sancho, clérigo regular prepósito. ${ }^{513}$

A tal petición se respondió afirmativamente con fecha de 19 de mayo de 1779: "Dése por el archivero en la antigua Diputación en este Reyno, las certificaciones que solicita esta parte, de lo que constate y fuere de dar». ${ }^{514}$ La temblorosa mano de Lezaun, correspondiente a un anciano, sólo se adivina en la firma, ya que el resto del documento corresponde a otra mano, muy probablemente la de su hijo, el erudito y malogrado Tomás Fermín.

Finalmente, otra certificación expedida por Lezaun hacía referencia al condado de Sástago y a ciertas cantidades que le pertenecían por el equiva-

509 Petición de certificación de un privilegio dado por Carlos V a favor de García Garcés de Teruel. A.D.P.Z., leg. 755-21. Los datos son obtenidos por Lezaun de una carta inserta en el registro de actos comunes de los diputados del reino de Aragón del año 1520, que se encontraba en el armario número 10 del archivo del reino.

510 A.D.P.Z., leg. 755-13.

511 A.D.P.Z., leg. 626-33.

512 A.D.P.Z., leg. 755-13.

513 A.D.P.Z., leg. 755-13.

514 Ídem. 
lente al antiguo peaje. ${ }^{515}$ Más allá de las fronteras zaragozanas, encontramos certificaciones del archivero Pedro Felipe de Lezaun en los más variados depósitos documentales. Así, en el archivo del barón de Valdeolivos, en la localidad oscense de Fonz, se encuentra la certificación del archivero de la antigua Diputación del reino fechada en 1777 con la que se constata que don Miguel Río, de Fonz, se matriculó y habilitó para las Cortes de Aragón de $1702 .{ }^{516}$ Una de las últimas certificaciones conocidas procede de la mano de don Manuel Antonio de Terreros, oficial de la contaduría principal del ejército de Aragón y archivero de la antigua Diputación. Este oficial fue probablemente el padre del último responsable del archivo del reino, don Santiago Terreros, quien habría de verificar todo el salvamento y puesta a buen recaudo de los documentos del antiguo archivo. ${ }^{517}$

En realidad, estas solicitudes nos hablan de la importancia que, una vez suprimida la foralidad aragonesa con el advenimiento borbónico, se otorgó a los documentos de la antigua Diputación. Con el transcurso del tiempo, se convirtieron en las pruebas documentales evidentes del pasado más reciente del reino de Aragón en general y de la Diputación en particular. ${ }^{518}$

$\mathrm{El}$ acto de expedir certificaciones sobre documentos que obraban en poder de los archivos de la extinta Diputación del reino de Aragón estuvo regulado en el siglo XVIII por diferentes disposiciones, con objeto de frenar esta práctica siempre que los documentos que se expidieran tuviesen una naturaleza contraria a los intereses de la hacienda regia en Aragón. En 1769, una real orden indicaba la obligatoriedad de que, en el momento de la expedición, se hallase presente el contador principal del ejército de Aragón, con el fin de garantizar que la información documentada a certificar no era contraria a los intereses económicos de la Monarquía. También se detallan los requisitos formales y diplomáticos de las certificaciones a fin de que surtiesen el

515 A.C.A., Diversos, Patrimoniales, Sástago, lig. 4, n. ${ }^{\circ} 25$.

516 Fonz (Huesca), Archivo del barón de Valdeolivos, caja 197-13: «Don Pedro Felipe de Lezaun, archivero por su Majestad de los generales de la antigua Diputación y Baylía y Maestre Racional del Reyno de Aragón, certifico que en el mencionado archivo de la antigua Diputación a mi cargo, y en el almario veinte y quatro de él entre otros se halla el original registro del estamento y brazo de cavalleros e hijosdalgo hecho en las cortes convocadas por la S.C.R. Magestad del Señor Rey don Felipe Quinto [...]».

517 A.H.P.H, Casa Bardají, leg. 27-1-5: Certificación dada por don Manuel Antonio de Terreros, archivero de la antigua Diputación, a dos de agosto de 1798.

518 A.D.P.Z., leg. 755-13. 
efecto de documento probatorio. De hecho, una de las formalidades ineludibles era la necesidad de consignar las firmas del contador del ejército de Aragón, el intendente del reino y el archivero responsable de su escritura. ${ }^{519}$

\subsubsection{Consultas externas mediante envío}

Las escrituras del archivo del reino no podían salir de él ni de su edificio. Tampoco podían ser inventariadas ni ejecutadas, ni por tanto desprendidas bajo ningún concepto del archivo del reino. En 1446 Alfonso V disponía claramente que las escrituras custodiadas en los archivos del palacio de la Diputación no podían ser intervenidas. ${ }^{520}$

Al menos ésta era la teoría que presidía el concepto de custodia documental en la sede del reino en Zaragoza. Pero naturalmente existieron excepciones y algunos registros del archivo salieron fuera de las fronteras no sólo del palacio sino de la capital del reino. No obstante, como se observa en las fuentes consultadas, sólo fueron enviados registros y documentos a los brazos reunidos en Cortes y al rey cuando fueron solicitados. Tomar decisiones en un foro tan solemne y decisivo como son las reuniones de Cortes generales implica el conocimiento de los actos jurídicos y decisiones tomadas con anterioridad y registradas documentalmente. Convocar Cortes en una ciudad distinta de Zaragoza, circunstancia que era habitual, implicaba, por tanto, no tener cerca los elementos de juicio necesarios para fundamentar las decisiones de los brazos, ya que acudir a Monzón o a otra ciudad privaba, por la distancia, a los diputados, de su acervo documental, representado por el archivo del reino. Por consiguiente, la distancia fue la causa que motivó la adopción de decisiones arriesgadas pero necesarias en materia de consulta documental. Así, en las Cortes del año 1552 celebradas en Monzón, los diputados necesitaban urgentemente la consulta y exhibición de las bulas referidas a la Inquisición y de

519 A.D.P.Z., leg. 755-17. Vid. apéndice documental, n. ${ }^{\circ} 17$.

520 Savall y Penén (1866), vol. 2, p. 315: «E qualesquiere processos, registros, livros de contos e copias de aquellos e qualesquiere otras escripturas que segunt los actos de la Corte deven estar jus custodia, guarda e a mano de los Diputados del dito Regno o del notario, ordenado a custodia e guarda de las ditas casas e de las escripturas en aquella estantes e regimiento de aquellas, no devan ni sian por el señor Rey o su lugartenient en su caso, ni puedan ni sian por otros qualesquiere officiales executadas, emparadas, inventariadas o manifestadas; ni de las ditas casas de la Diputación en alguna manera sacadas. Excepto que por los censales devidos por la dita Cort e quatro braços de aquella». 
otros documentos precisos para apoyar otros asuntos debatidos en el transcurso de las sesiones de los brazos asistentes. Efectuada la correspondiente petición, los diputados enviaban a sus compañeros los testimonios solicitados. Naturalmente, las condiciones de seguridad y protección de los documentos originales fueron una preocupación recurrente. ${ }^{521}$

Años más tarde, las magnas Cortes del año 1585, también celebradas en Monzón, asistieron al importante envío de registros originales desde Zaragoza. Para tan delicada misión, se facultó al archivero de la Diputación para que se pusiera al frente de un envío de documentos que se precisaban en Monzón y los llevase con todo celo y cuidado a la localidad oscense. Tales fueron las medidas y prevenciones que los diputados hicieron cumplir para que la documentación no se extraviase bajo ningún concepto, que a la comitiva documental se le asignó una escolta especial compuesta por los integrantes de la guarda del reino, cuyo número quedaba a voluntad del archivero, así como la fabricación de un mueble escritorio apropiado para garantizar su seguridad con la especificación de su «buena cerradura». ${ }^{522}$

Además de todas estas precauciones, se encomienda especialmente al archivero, como último responsable de los documentos y su integridad, que no se pierdan durante el trayecto. Es más, tal era la consideración y valor otorgado a la documentación del reino y que salía en esta ocasión extraordinaria de las salas del palacio, que los diputados incluso le obligaron a jurar que pondría su empeño en velar por su seguridad en todo momento.

Éstas no fueron las únicas ocasiones en que la documentación albergada en el archivo de la Diputación emprendía camino fuera de los lími-

521 Registro de actos comunes del año 1552, A.D.P.Z., ms. 689, f. 32v: «Luego que reçebimos la carta de vuestras señorías y mercedes con Bartholomé Malo, hizimos mirar en el archiu las bullas que por dicha causa piden, y assí habemos dado al dicho Bartholomé Malo dos bullas originales plúmbeas confirmatorias de los capitoles de la inquisición y principado de Cathaluña, y una observancia del Papa Adriano, haunque aquella fue hecha ante de su pontificado siendo inquisidor general, los capitoles que se piden del año de diez y nuebe tocantes a la inquisición, no se han hallado en el registro de cotes del año de 19; es verdad que se a hallado en un registro de los actos comunes del reyno una copia signada que el dicho Bartholomé Malo estava de partida, no los puede llebar; probeheremos en que se saquen y los embiaremos con el primero que se ofreciere; a vuestras señorías y mercedes suplicamos que dichas bullas estén muy guardadas de tal manera que vistas por las personas que las han de ver, se buelvan a embiar a buen recaudo para que las bolvamos al archiu».

522 Tomás Fermín de Lezaun y Tornos, Apuntaciones históricas..., B.N.E., ms. 9823, f. 88v. Vid. apéndice documental, n. ${ }^{\circ} 16$. 
tes de las salas del palacio contiguo a la puerta del Ángel. De hecho, para las Cortes celebradas en Tarazona en 1592 se vuelve a solicitar documentación, esta vez por parte de Felipe II, quien por medio de dos misivas pide diversos registros custodiados en el archivo. A tal efecto envió un notario, quien no sólo examinó la documentación que precisaba el monarca, sino que, si lo estimaba necesario, estaba facultado para obligar a los diputados a entregársela por el tiempo que él dispusiera. ${ }^{523}$

En una segunda carta del monarca a los diputados aragoneses, fechada sólo veintiún días más tarde, se especificaba la persona que debía presentarse en el archivo para examinar la documentación y llevarse la que fuera precisa o bien se sacasen copias auténticas y validadas por el notario de la Diputación: «por otra parte se os ha ordenado que comunicáredes los Rexistros de Corte que hay en la Diputación de ese Reino y diésedes traslados y lo demás necesario a don Miguel Clemente, nuestro protonotario y porque iría delante Micer Baptista, Regente el oficio de Justicia de Aragón, y para muchas cosas será necesario que él vea los dichos registros y les tenga a su mano, os encargo que se lo comuniquéis y entreguéis por el tiempo que dixere que lo ha menester y en hazerlo así, seré de vosotros servido».524

Para preparar la documentación, los diputados dieron las órdenes precisas para que el archivero sacase los documentos solicitados y además, como sucedió en las Cortes de Monzón de 1585, los llevase esta vez a Tarazona. No obstante, nos parece fundamental resaltar el control que se ejercía sobre la documentación que salía del archivo. En último término era un asunto regulado por fueros, y la memoria escrita del reino, merced al concepto de patrimonialidad exclusiva, era competencia absoluta de la Diputación como garante de la integridad y unicidad de la documentación. Al final se especifica que de todos los documentos que se envíen a

523 Ibídem, f. 134r y ss.: "A 6 de mayo [1592], Lanuza, regente el oficio de Justicia de Aragón, dio a los diputados siguientes cartas: el Rey: Diputados para las Cortes que he convocado y he de celebrar a las de este Reino en la ciudad de Tarazona, serán menester algunos papeles, escrituras y exemplares tocantes a estas materias de los que huviere archivados en el Archivo de esa Diputación, y así os encargo y mando que deis orden a las personas a cuio cargo estubiese el dicho Archivo que saque de él todo lo que es necesario de copias o originales como os lo escriviese don Miguel Clemente, nuestro protonotario, embiándole a sus manos los dichos papeles con toda brevedad y diligencia, dándole entero crédito en lo que de mi parte os avisare sobre estas cosas, que en ello me serviréis mucho. Datum en Madrid a 6 de Abril de 1592. Yo el Rey».

524 Ibídem. 
Tarazona se deje ápoca o recibo de salida, como medio de tener controlada la documentación saliente. Por último, subrayamos que, con motivo de tratarse de una misión que excedía el cometido y la responsabilidad directa del oficio de archivero, se le asigna un salario que hoy en día podríamos comparar a las dietas de desplazamiento. ${ }^{525}$

Otras circunstancias en las que se asistió al traslado de escrituras desde Zaragoza fueron las escasas ocasiones en que el consistorio se trasladó por alguna razón, generalmente sanitaria, a otras localidades. En septiembre de 1523 los diputados pedían al notario de la Diputación que llevase a Magallón «las caxas, libros, llaves y todo lo de la capilla, que el dicho portero se verná con vos». 526

\subsection{Negligencias en la tramitación y custodia documental}

Por encima de cualquier otra consideración, las funciones del archivo durante el Antiguo Régimen pivotan en torno a la idea de custodia y seguridad de la memoria escrita. Los conceptos de acceso y consulta de los documentos se encuentran muy delimitados, y guardar celosamente la información documentada es un precepto continuamente esgrimido en ordenanzas, memoriales y cuantas tipologías desarrolle la administración del archivo. El archivo al servicio del poder es instrumento de dominio y control. Como indica muy acertadamente Rodríguez de Diego para el archivo de Simancas, la patrimonialidad y el secretismo constituyen mecanismos eficaces de poder. ${ }^{527}$ De hecho, como manifestaciones palpables de

525 Registro de actos comunes del año 1591, A.D.P.Z., ms. 261, f. 117r-117v, 128r-128v: «En virtud de estas cartas, haviendo de marchar Lanuza el día 8, se mandó a Gerónimo Oliva, notario substituto de la Diputación en ausencia del Principal, [que] Miguel López sacase del Archivo varios Rexistros de Cortes que pedía los llevase a Tarazona a las Cortes que se celebraban y los mostrase al dicho Lanuza, siempre que los huviese de menester. Señalándole de salario 2 libras jaquesas diarias mientras estubiese en Tarazona. Y a 23 de mayo se sacaron otros Rexistros que havía pedido, y se le entregaron como los que havía llevado Oliva, dexando ápoca. A 26 de mayo, escrivió Lanuza desde Tarazona embiando un portero de su Corte de Justicia de Aragón para que con su recivo y en virtud de poder que le avía otorgado, le entregasen los demás Registros que huviese en el Archivo, y así se hizo el día siguiente».

526 Registro de actos comunes del año 1523, A.D.P.Z., ms. 117, f. 19r

527 J. L. Rodríguez de Diego (1998), pp. 31-32: «Y así, estos caracteres de patrimonialidad, secretismo o inaccesibilidad, que tanta correspondencia guardan con la índole 
la idea de depósito cerrado con acceso muy restringido, se debe recordar la puerta del archivo cerrada con cuatro llaves, una por cada brazo, además de una quinta en poder del archivero. Al igual que sucede en el concejo de Alcalá de Henares, y como práctica extendida y habitual en los archivos de la Edad Moderna, "la accesibilidad al contenido de su interior se protege bajo el cierre de diversas llaves, normalmente tres o cuatro, entregadas a diversas personas. De ese modo, para poder abrir el arca y sacar de ella cualquiera de las escrituras contenidas, es preciso que se encuentren presentes todos los portadores de las llaves». ${ }^{528}$

Para el caso que nos ocupa, el recurso al carácter patrimonial de la documentación del archivo del reino despliega todo su significado en el momento en que la memoria documental lo es del reino, incidiendo en la patrimonialidad de la escritura por parte de una colectividad, la aragonesa, cuyos máximos delegados y responsables de la custodia resultan ser los diputados aragoneses.

Por otra parte, las formas concretas en que se ejercita el secretismo del archivo se evidencian en las frecuentes indicaciones sobre el ceremonial desarrollado en el acceso y apertura de las puertas del archivo. Naturalmente, el mejor modo de comprender los casos concretos en que se manifiestan estas manifestaciones externas del poder de lo escrito lo constituyen las ocasiones en que el archivo fue consultado por variados motivos. En los apartados anteriores se ha comprobado cómo el archivo del reino recibe un importante número de consultas por parte de interesados en procedimientos administrativos tanto internos como ajenos a la propia institución. Sin embargo, la cohesión de la idea de protección vigilante de los documentos es a veces vulnerada por situaciones que derivan de una negligencia archivística en el acceso y vigilancia física de los registros y escrituras del reino.

Las disposiciones forales recuerdan continuamente la necesidad de la vigilancia y el cuidado en la custodia, como primeras funciones de los responsables del archivo, algo por otra parte común a los depósitos documentales del período. En las Cortes de Tarazona de 1592, epílogo norma-

absolutista del período moderno, no son en modo alguno abstracciones encajables en el esquema de gobierno propio de una época o en el discurso evolutivo de la ciencia archivística, sino realidades comprobables en la utilización por el monarca de ese polo de poder que se llama archivo».

528 Antonio Castillo (1997), p. 255. 
tivo a las alteraciones del año anterior, se incidía en la conveniencia de guardar celosamente los testimonios escritos del archivo, con especial hincapié en el permiso concedido a la consulta documental, siempre con el beneplácito de la cabeza visible del consistorio. ${ }^{529}$ También el fuero de 1678 «Del archivero del Reyno» establece que si el archivero falta a su oficio, los diputados están habilitados para resarcirse del daño causado por el archivero, llegando a privarle de su empleo. ${ }^{530}$

Sin embargo, es preciso indicar que la protección jurídica al concepto de patrimonialidad y custodia comienza en el ámbito de la génesis de los documentos de la Diputación, afectando por tanto al equipo de notarios y escribanos. En las Cortes de Monzón de 1528 se delimitaba la responsabilidad del notario en caso de pérdida de procesos y registros:

De los processos que se pierden, a cuyo peligro ha de ser.

Acaesce muchas vezes que se pierden, o se ocultan processos en grande daño de las partes. Por evitar aquello, su Magestad, de voluntad de la Corte statuece y ordena, que los processos que se perdieren o se ocultaren, sean a cargo del Notario, a quien toca la detención y custodia de dichos processos; el qual notario sea tenido y obligado a todo el interese de la causa, y a otros daños, que la parte hoviere sostenido, o reformar el proceso a costas suyas; de tal manera, que la parte por la ocultación del dicho processo no reciba daño alguno; y los dichos notarios sean tenidos y obligados a tener y cumplir lo dispuesto y ordenado en el presente Fuero a sola declaración del luez, ante quien será actitado el dicho processo; la qual, el dicho Iuez sea tenido de hazer sumariamente sin estrepitu \& figura de judicio, sola la verdad del hecho acatada; y la dicha sentencia si quiere declaración, haya de ser executada, no obstante Firma de qualquiere especie que sea: adjunción, apelación, ni otro embargo alguno. Y que para escusación del dicho Notario no le pueda aprovechar cosa alguna, sino que muestre, como el tal proceso ocultado, o perdido, lo dio al Juez, a quien pertenesce la deliberación del dicho processo; y que escriptura privada de mano del Iuez escripta, o sotascripta, sea legítima provança, para escusación del dicho notario. ${ }^{531}$

529 Savall y Penén (1866), vol. 2, pp. 366-367: «Mucho conviene que los registros y escripturas de la Diputación estén bien guardadas. Por tanto, su Magestad de volundad de la Corte estatuye y ordena que los registros, determinaciones y todas las demás escripturas de la Diputación se pongan en el Archiu delle en cada un año a donde están las arcas de los oficios del Reyno. Las quales no puedan ser sacadas de allí sin voluntad de la mayor parte de los Diputados, que tienen las llaves del dicho Archiu».

530 Savall y Penén (1866), vol. 1, p. 515: «Otrosí que no pueda entregar processo alguno a otros que a los actuarios o regentes de las escrivanías con ápoca de aquellos y no de otra manera y para que conste de los processos que salieren de dicho archivo y de su poder, deva tener un libro de ápocas en que escrivan todas las que hizieren de los processos».

531 Savall y Penén (1866), vol. 1, p. 75. 
Perder documentos no sólo atenta contra la correcta gestión administrativa de la institución. Además, y lo que resulta más grave, se comete una inexplicable violación de uno de los pilares en los que se asienta la identidad del reino: la memoria escrita custodiada en el archivo del reino es la garantía del pasado y fianza para el futuro. Perder documentos o permitir que individuos o instituciones no autorizadas accedan a ellos implica, por tanto, un perjuicio doble: uno estrictamente en el plano administrativo (lagunas documentales demostradas ya durante los siglos XVI y XVII); y otro en el ámbito más excelso que provoca un contraste jurídico, el hecho de que la institución garante de la conservación del ordenamiento jurídico y las disposiciones forales se permita un fallo tan gravoso como la pérdida de la propia documentación.

Resulta también cierto que dichos extravíos fueron los menos, y a continuación se pusieron en marcha las medidas coercitivas para castigar a los responsables de tamaña negligencia. De hecho, en 1576 el diputado Villanueva suplicaba a sus compañeros diputados que
Manden al dicho Miguel López assista en su alcaydía y presidio y custodia de las casa, archio y cosas del Reyno o si no lo pudiese hazer, nombre si a vues- tras señorías paresciere en lugarteniente suyo durante su voluntad y del con- sistorio al dicho Hierónymo Andrés, el qual sea tenido prestar homenaje, jura- mento y sacramento de manos y de boca a los dichos señores diputados que son y por tiempo serán de haverse bien y lealmente en su officio y custodia de llaves de la alcaydía [...]. ${ }^{532}$

Sería precisamente Jerónimo Andrés otro de los archiveros custodios del archivo del reino, vinculando así el cargo entre vigilantes perpetuos del edificio con el oficio de custodios documentales. Más adelante, el citado diputado Villanueva insistía en la necesidad de que se avisase a Miguel López y a Jerónimo Andrés para que entregasen todos los registros y escrituras que anduviesen dispersos por las escribanías de la Diputación. Además, se advertía una velada crítica a la actitud de López, ya que su escaso celo vigilante propiciaba que algunas personas hubieran accedido a la documentación del reino, acceso totalmente prohibido sin consentimiento expreso de los diputados. ${ }^{533}$

532 Registro de actos comunes del año 1576, A.D.P.Z., ms. 231, f. 43v-46r.

533 Ibídem, f. 43v-46r: «Traygan a poder del consistorio / mediante juramento \todos los processos actitados en la dipputación y los registros y negocios continuados / matrícu- 
Uno de los casos que más repercusión tuvo lo protagonizaron dos personalidades dentro del panorama administrativo de la Diputación: por una parte, Pedro López, hijo de Miguel López, el anteriormente citado secretario, escribano principal, archivero y alcaide del palacio, y por otra, el célebre Lorenzo Ibáñez de Aoiz, teniente de alcaide y autor del importantísimo Ceremonial y Breve Relación de todos los oficios del Reino, obra de capital importancia para comprender la estructura orgánica y funcional de la Diputación. Descendiente de una familia vinculada a los oficios del reino, Pedro López es acusado en 1615 de haber descuidado la vigilancia de los procesos del archivo. ${ }^{534}$

El secretario había dejado las llaves del archivo a Ibáñez de Aoiz, incurriendo en una falta grave, habida cuenta de que el teniente de alcaide no tenía derecho a custodiar las llaves del depósito documental. El resultado fue la falta de vigilancia del archivo, propiciando que las puertas se dejasen abiertas y ciertas personas entrasen y sacasen un gran número de procesos y escrituras, «en gran perjuicio del Reino». Ante este hecho, la Diputación inició un proceso contra ambos funcionarios. El veredicto de los diputados, apoyado por la corte del Justicia, se hizo público en los términos siguientes: «Resolvieron los ocho señores diputados todos conformes, que se suspenda a Pedro López del officio y officios de archivero de la diputación como dende luego le suspenden durante el beneplácito y mera voluntad de los señores diputados y así mismo, se haze mandamiento a los procurado-

las de los officios así biejas como nuevas / para que se haga una rúbrica y memoria y se assienten y pongan en el archio principal, con las chorónicas, registros de cortes y otras cosas que se tiene el dicho Miguel López en su aposento; que aunque tiene nombre de archio, no lo es más de querer tener descanso y dello resulta muy notable daño a los regnícolas y se offenden las libertades del reyno porque están debaxo la custodia del dicho Miguel López y entran y salen quien quiere, y quando es menester un exemplar así para la justicia como para lo çerimonial y otras cosas que se offrescen con la real Magestad y sus officiales y con reynos y provincias estrangeros, está tan ciego todo que han menester tener por intérprete a quien guardándose el orden arriba dicho será menester poco fatigar y desta suerte los dipputados sabrán lo que han de hazer y harán justicia a las partes, cumplirán con sus officios y juramento y sentencia de excomunión que tienen prestados [...]».

534 Recordemos que el 6 de octubre de 1623 Pedro López, como secretario, alcaide de la Diputación, archivero y a su vez familiar del Santo Oficio, fue requerido por los inquisidores para que les mostrase un registro con los insaculados en los oficios del reino. Los diputados intervinieron accediendo con reticencias a la petición. Pero el hecho indudable era que el secretario tenía acceso a la documentación del reino y constituía un cargo de poder en el seno de la institución, puesto que controlaba la información contenida en el archivo. 
res extractos del reyno hagan parte contra dicho Pedro López y Lorenzo Ybáñez de Aoyz por las razones que se contienen en esta consulta». ${ }^{535}$

Junto a estas negligencias en la vigilancia del archivo, la documentación del reino, como objeto de poder y control, testigo escrito a su vez de numerosas transacciones comerciales, va a ser objeto de hurtos y transformaciones con la intención de alterar u ocultar gestiones poco claras de algunos funcionarios integrados en la estructura del consistorio aragonés. El continuo y abundante trasiego de documentación emanada desde la Diputación o dirigida a ésta, obligaba al mantenimiento de una extensa red de agentes, informadores, oficiales de aduanas y otros funcionarios que basaban el resultado de su gestión en el testimonio escrito. Anotar las mercancías que transitaban por una tabla y las cantidades pagadas en concepto de abono del impuesto de generalidades, por fuerza requería del auxilio de la documentación administrativa. La distancia de dichos oficiales con respecto a la capital del reino favoreció en algunas ocasiones la comisión de fraude al anotar cantidades incorrectas y alterar precios y cantidades en beneficio particular de los oficiales, con el consiguiente perjuicio para la hacienda del reino. De hecho, los libros de cuentas de las generalidades ofrecían un registro puntual de la gestión del impuesto de entrada y salida de bienes del reino y su alteración podía ser perseguida por diferentes actores decididos a cometer fraude económico contra la hacienda aragonesa.

Toda esta producción documental también se vio sometida al azar de las posibles pérdidas, extravíos y robos intencionados. Queda testimonio de la pérdida de uno de estos libros, correspondiente a la tabla de Calatayud, que acaeció en 1645. Un portero del reino fue objeto del robo de los libros de la administración de la tabla del general correspondiente a Calatayud. El desafortunado portero había dejado dichos libros en el mesón donde se alojaba, y descubrió poco después tamaño robo. Ante tal incidente, los diputados consultaban inmediatamente a sus abogados a propósito de los trámites necesarios para acusar y proceder a capturar al sospechoso del robo: nada menos que el tablajero de dicha tabla, es decir, el encargado de haber redactado dichos libros. Los motivos de la sustracción no se especifican, aunque bien pudieran relacionarse con una mala gestión registrada documentalmente. ${ }^{536}$

535 Registro de actos comunes del año 1614, A.D.P.Z., ms. 334, f. 260v-263r.

536 Registro de actos comunes del año 1644, A.D.P.Z., ms. 449, f. 155v y ss. 
En el conjunto de actuaciones irregulares respecto a la custodia y permiso de acceso a la documentación, el ínclito secretario de la Diputación, Jerónimo de Naya, estuvo envuelto en un flagrante caso de extracción de registros del propio palacio de la Diputación. Así, los diputados lo acusaron en septiembre de 1650 de haber permitido la salida de documentos del archivo y de la sede del reino. ${ }^{537}$

Más adelante, en las Cortes celebradas en Calatayud y Zaragoza bajo el reinado de Carlos II en 1678, se establece una disposición con el fin de subsanar la posible pérdida de documentos por parte del archivero. ${ }^{538} \mathrm{La}$ reparación es de tipo económico y se ejerce sobre la fianza que debe depositar el archivero cuando es aceptado como responsable directo del archivo. En caso de pérdida, se puede recuperar el dinero depositado, para reparar la falta, e incluso disponer de su sueldo y privarle de su remuneración anual e incluso de su empleo. Debemos también resaltar el instrumento de control sobre el que se apoya esta disposición: el libro de ápocas. Este libro de recibos o comprobantes de la documentación prestada a los diputados por parte del archivero, debe ser presentado al conjunto de los diputados con el fin de comprobar qué ápocas hacen referencia a documentos que están todavía sin reintegrar al archivo: «y para que conste de los Processos que salieren de dicho Archivo, y de su poder, deva tener un libro de ápocas, en que escrivan todas las que hizieren de los Processos. Otrosí, que en cada un año los Diputados devan disponer el que dicho Archivero lleve al Consistorio el libro de las ápocas, para saber qué Processos faltan, pedirle cuentas de ellos; y en caso de no darla a satisfación, o haverse perdido algún Processo, puedan condenarle, y también a sus fianças, a satisfacer, y resarcir el daño a la parte interesada».

537 B.N.E., ms. 8380, f. 263: «Del officio, poder y jurisdición de los ilustrísimos Señores Diputados del Reyno de Aragón».

538 Savall y Penén (1866), vol. 1, p. 516. 


\section{VALOR Y FINES DEL ARCHIVO DEL REINO}

\subsection{Los valores de registros y escrituras para la institución productora}

Si en los capítulos anteriores nos hemos ocupado de indicar las tareas de organización documental a las que se vio sometido el archivo del reino, es ahora momento de reflexionar sobre la intención última que subyacía al mantenimiento de una política archivística y administrativa coherente.

El valor de los testimonios escritos como instrumentos de control político, administrativo y al servicio de la estructura de gobierno de la que emanan ha sido un fenómeno analizado desde hace relativamente poco tiempo. ${ }^{539}$ Hespanha indicaba la íntima conexión entre el proyecto político de la Monarquía austríaca y la organización documental desde el siglo XVI, característica común por otra parte al resto de las instancias de poder, tanto desde el centro de la monarquía hispánica como desde los reinos periféricos. ${ }^{540}$ Las últimas aportaciones hechas desde el estudio de la his-

539 Una de las obras clave que analizan la génesis de la escritura condicionada esencialmente por la necesidad de control administrativo y político de una civilizacion es el libro de Jack Goody (1990). Véase también la obra ya clásica de Henri-Jean Martin (1999). Reveladora ha sido la obra, considerada un punto de referencia básico, de Fernando J. Bouza Álvarez (1992) y (1999b). El archivo como instrumento de poder al servicio de la Monarquía aragonesa durante la Edad Media se puso de manifiesto en el trabajo de Rafael Conde $(1994 a)$.

540 A. M. Hespanha (1989), p. 228: «Por último, el registro escrito constituye un medio revolucionario - respecto a las técnicas de la oralidad - de almacenar la información. Archivos, catastros, mapas y plantas, descripciones corográficas, códigos, he aquí una enorme gama de materiales de apoyo a la decisión política que, ahora, están a disposición del monarca». 
toria de los archivos situados en los territorios peninsulares de la monarquía hispánica, así como el creciente interés por la denominada historia social de la cultura escrita, han proporcionado un interesantísimo cúmulo de informaciones y, lo que es más importante, nuevas perspectivas de estudio. ${ }^{541} \mathrm{El}$ rendimiento que el poder extrae de la escritura organizada como instrumento al servicio del poder queda demostrado en los más recientes trabajos centrados en compaginar el ejercicio de gobierno castellano con un adecuado sistema documental cimentado en la organización archivística de la monarquía hispánica. ${ }^{542}$

En dos magníficos trabajos publicados no hace mucho por José Luis Rodríguez de Diego, se ponía de manifiesto una triple concepción de los archivos surgidos en la época moderna, tomando como caso de estudio, mediante un análisis de carácter sincrónico, el archivo por antonomasia de la monarquía hispánica: el Archivo General de Simancas. ${ }^{543}$ No obstante, todavía recientes estudios sobre el significado y finalidad de estos centros documentales de los siglos XVI y XVII han vuelto a incidir en la separación tradicional entre archivo al servicio de la institución o poder que los crea, el servicio ofrecido por la documentación en ellos custodiada como elemento básico para mantener su engranaje administrativo y, finalmente, la posible consulta de dichos fondos documentales con fines eminentemente de investigación histórica, para constituir los denominados «laboratorios de la historia». Sin embargo, ejemplos como los de Simancas o el del archivo de la Diputación del reino de Aragón permiten descubrir una presencia conjunta de estas tres funciones. Se trata, por tanto, de concebir el archivo en la época moderna desde una perspectiva integradora de funciones en virtud de las consultas y el uso que se haga de la documentación que aquél custodia, y ello durante el período coetáneo a la existencia de la entidad generadora y creadora del archivo. En definitiva, «simultáneamente se darían archivos del poder, de la administración y de la historia». ${ }^{544}$

Esta circunstancia de convivencia simultánea de tres «valores» del archivo en su conjunto nos permite analizar la triple integración en un

541 En este sentido, es fundamental la consulta del capítulo titulado «Cultura escrita, poder y organización de la sociedad» de la obra de Antonio Castillo Gómez (1997).

542 Elisa Ruiz (1999). Fernando Bouza (1999a) y (1999b).

543 José Luis Rodríguez de Diego (1998a) y (1998b).

544 J. L. Rodríguez de Diego (1998a), p. 29. 
archivo que, si bien responde a las mismas inquietudes de control y organización de los documentos en la Edad Moderna, no lo hace en cuanto al ente productor. Esta institución es la Diputación del reino de Aragón, entendida como representante de los llamados "polos opuestos» de la monarquía hispánica. ${ }^{54}$ Porque a pesar de las diferencias lógicas existentes entre la institución representante de la colectividad «regnícola» y las instituciones insertas en el régimen polisinodial de la monarquía hispánica, el análisis del uso de la producción documental de la Diputación aragonesa demuestra que, al igual que otras instituciones de la época, su archivo tuvo una triple función sincrónica de órgano de servicio para el poder institucional que lo crea (Diputación del reino), para su administración (tanto económica como de justicia) y para la construcción histórica de la memoria del reino de Aragón en la Edad Moderna y, llegado el caso, su utilización propagandística.

Como hemos visto anteriormente, en el proceso evolutivo de la Diputación del reino de Aragón se aprecia un progresivo aumento competencial, que tiene su culminación definitiva a mediados del siglo XV. En un principio, nada hace pensar que la Diputación, común en su concepción original al resto de diputaciones o delegaciones de representantes del reino nacidas después de una convocatoria a Cortes, pueda alcanzar un nicho de poder más allá de la gestión económica: una gestión centrada en la prestación del servicio al monarca después de su votación y aprobación en Cortes, así como en la correcta administración del incipiente impuesto de «generalidades», aprobado en las Cortes de Monzón de 1362. ${ }^{546}$ Sin embargo, la Diputación va a incorporar paulatinamente a la función estrictamente económica la de rectora de la política de Aragón y, lo que es más importante, los diputados van a considerarse como los verdaderos representantes del conjunto del reino y los defensores de su particular ordenamiento jurídico. ${ }^{547}$

545 José Ángel Sesma (1977) y (1981) y J. Á. Sesma y J. A. Armillas (1991).

546 José Ángel Sesma (1977), pp. 33-36.

547 José Ángel Sesma y José Antonio Armillas (1991), p. 45: «Así pues, la Diputación llega al último tercio del siglo XV con amplios poderes para controlar la paz interna y externa, se constituye en guardián del orden y en árbitro de las rivalidades entre nobles y universidades y, sobre todo, se hace con el control del Justiciazgo [...]». 
Para mantener esta posición de defensa frente a las posibles vulneraciones del entramado foral, la Diputación del general se va a valer esencialmente de la convocatoria de los brazos del reino y del poder ejecutivo contra los alteradores del orden. ${ }^{548}$ Sin embargo, debajo de estos dos instrumentos generales subyace todo el complejo administrativo y documental que permite a la Diputación fundamentar sus actuaciones dirigidas a defender el orden institucional establecido. Es decir, se contempla el recurso a la documentación como un argumento básico para la defensa político-jurídica del reino, ofreciendo así un magnífico ejemplo de lo que podríamos denominar manifestaciones institucionales del poder de lo escrito en el reino de Aragón. Podría decirse, por tanto, que, al igual que los jurados de Teruel habían protestado contra la Inquisición en aquel territorio, los diputados del reino aplicaron entre otros métodos «la defensa de este Reino con leyes, papel y tinta». ${ }^{549}$ De hecho, como apunta Sesma, se trata de la sociedad de lo escrito, donde «la escritura se empleará como instrumento. Las órdenes e instrucciones de la autoridad se consignarán en documentos con sellos, firmas y rúbricas de autenticación. Las cancillerías y escritorios de las instituciones se convertirán en órganos fundamentales del aparato del poder y, por último, los archivos, concebidos como cámaras para atesorar la memoria colectiva, la ley y la tradición, se establecen y protegen por las diferentes instancias nacionales». ${ }^{550}$

\subsection{El valor de lo escrito para el gobierno y la administración}

Centrándonos en la función de gobierno de los diputados, sus competencias se manifiestan en series documentales concretas, que ocuparon su armario correspondiente en el archivo del reino. Siguiendo con el paralelismo propuesto en el caso del archivo de Simancas, las manifestaciones del poder evidenciadas en el archivo de los diputados del reino de Aragón se pueden analizar también desde los conceptos de patrimonialidad, secre-

548 J. Á. Sesma y J. A. Armillas (1991), p. 48.

549 Á. San Vicente (1992), p. 405.

550 J. Á. Sesma (1987a), p. 271. 
tismo e inaccesibilidad. ${ }^{551}$ De hecho, la conciencia de los diputados sobre su misión de garantes de la memoria escrita descansaba sobre estos tres conceptos y, no en vano, la custodia documental recaía por lo general en una única persona, aunando simultáneamente los cargos de secretario, alcaide de la Diputación y archivero general. Fruto de esta consideración, en 1576 el diputado Villanueva escribía acerca de la necesidad de extremar la vigilancia de los documentos por parte del secretario López:

Que el dicho su padre le recabó dicho officio de escribano principal y aunque es verdad que el assentar en los cabreos los censales que el reyno haze es de mucha confianza, empero es la muy mayor ser alcayde de la dipputación y con este fin se le tiene assignado salario sobre las generalidades el qual es officio de tanta confianza, que no se puede fiar ni encomendar sino a persona tal como lo es dicho señor Miguel López, y es en effecto por evitar prolixidad, lo que a su cargo está confiar un presidio del castillo de Milán o otra cosas semejante y assí se le entregan las llaves en el principio de su officio [...] porque si esto no se haze, en un día se puede perder todo lo que los reyes de Aragón y en cortes se ha hecho en favor deste reyno, a más de las pagas que el reyno ha hecho de dozientos y quinientos años a esta parte, lo qual consiste en la guarda de la alcaydía y en la confianza que del alcayde o su teniente se ha de tener y como el dicho Miguel López, por tener como tiene casa muy principal en donde vivir muy regalado y con el aucthoridad y honor que persona tan principal meresçe, $[\ldots] . .^{552}$

Ya en el apartado dedicado a las consultas de documentación custodiada en el archivo, se ha indicado que los diputados constituyen el grupo principal de utilización del testimonio escrito para cimentar sus decisiones en función de la costumbre registrada.

Junto al valor del archivo puesto al servicio del gobierno de la institución que lo crea, existe el servicio ofrecido por el archivo para mantener y apoyar la tramitación y génesis administrativa. Una administración que en el caso de la Diputación del reino se proyecta en dos direcciones: una administración interna, destinada a la gestión del funcionamiento de la institución, y una administración externa de doble carácter: la importantísima administración económica del impuesto aduanero de las generalidades y la paralela administración de justicia por parte de los diputados en los casos de fraude que contra dicho impuesto se cometiesen.

551 J. L. Rodríguez de Diego (1998a), p. 31, n. 1.

552 Registro de actos comunes del año 1576, A.D.P.Z., ms. 231, f. 43v-46r. 
De forma análoga, la tipología documental derivada de estas funciones conforma la organización documental de la Diputación. Así, tenemos las series de los registros de asistencias de diputados a las sesiones ordinarias del consistorio zaragozano, para controlar la gestión de cada diputado. También la administración económica interna se halla representada por los registros de ápocas de salarios, comisiones y consultas, mediante las que se observa el desembolso de la Diputación para pagar numerosas partidas de diferente índole (pago de salarios a los oficiales, contratos de obras, pagos al impresor del reino, limosnas, reparos de puentes y caminos, etc.). La gestión administrativa del impuesto de generalidades se puede observar en los libros de cuentas del general y en los registros de ápocas de censales cargados sobre el general del reino. La jurisdicción civil de la que gozaban los diputados en materia de delitos cometidos contra la administración del impuesto tuvo su correlato documental en varias series, entre las que se encontraban los procesos civiles de fraude y la consiguiente ejecución por medio de la ocupación de bienes a los infractores.

En este sentido, la regulación de la elaboración de los tipos documentales emanados de los «oficios» del reino se encuentra recogida en los fueros, observancias y actos de corte y continuamente en los registros de actos comunes, que dan noticia de la gestación y traspaso al archivo, una vez «fenecidos», de los procesos, registros y otras tipologías. Por tanto, la tramitación administrativa dentro de la Diputación del reino se halla notablemente delimitada desde el ordenamiento jurídico general (representado por los actos de corte) y más concretamente por las ordenanzas («ordinaciones») y disposiciones de carácter interno debatidas y aprobadas en el seno de la misma institución por los diputados. ${ }^{553}$

De lo adecuado de la organización de los registros depende por tanto su correcta conservación como bien patrimonial del reino, y como eficacia del servicio dado, en primer lugar, a los propios diputados. No se debe olvidar que éstos basan numerosas decisiones en la consulta de los registros y los documentos de épocas anteriores. Así, no es infrecuente que los diputados soliciten la apertura del archivo para conocer la reso-

553 Existen copias manuscritas de este reglamento en A.D.P.Z., ms. 657, así como en A.M.Z., ms. 15 (1513-1514). Publicadas por Savall y Penén (1866), vol. 2, pp. 320 y ss. 
lución adoptada por el equipo de gobierno de años anteriores en asuntos acaecidos en fechas precedentes y que de nuevo volvían a suscitarse. Para su resolución se recurría a los registros custodiados en el archivo, ilustrando así el valor del ius consuetudinarium en la resolución de situaciones para las que no existía legislación, tan sólo la costumbre plasmada por escrito. Como ejemplo sólo nos detendremos en la necesidad de consultar los registros por parte de los lugartenientes de la corte del Justicia, con el fin de dilucidar si éstos estaban obligados a jurar el oficio cada mes. Para ello, enviaron al secretario del Justicia con el fin de resolver la situación. A continuación, los diputados, por iniciativa propia, resolvieron abrir el archivo y consultar la documentación para decidir sobre el asunto. 554

La segunda dirección de las tareas administrativas está directamente relacionada con la gestión del impuesto de generalidades, ámbito de actuación inicial de la Diputación y que fundamentó su creación a fines del siglo XIV. La balanza económica del reino dependía del control y correcta gestión del impuesto, bien fuese por arrendamiento o por gestión directa de los diputados. Los fraudes y posibles alteraciones de dicha gestión sólo son controlables mediante la constancia documental. ${ }^{.55}$ Los inquisidores de cuentas revisan los libros de los administradores al final de cada ejercicio económico. Sin embargo, la documentación referida a la gestión de las "generalidades» y los beneficios económicos derivados de este impuesto ocupa un considerable número de legajos del total producido por la institución. Así, es preciso citar los registros de ápocas de censales (o deuda

554 Lorenzo Ibáñez de Aoiz, Ceremonial..., B.N.E., ms. 2922, f. 331r-331v: «A 28 de nobiembre 1654, los señores lugartenientes de la corte del señor justicia de Aragón por estar vaco el dicho oficio y serbir los lugartenientes, pretendieron que no debían de jurar cada mes como tienen obligación conforme a fuero, pues el señor justicia no jurava y representar hoy aquellos el dicho oficio; y para saber esto, embiaron al consistorio a su secretario con recado a los señores diputados; Y sus señorías respondieron que entendían que devían jurar y que para mayor satisfación subieron al archivo a ver los registros de los años 1622 y 32 que estuvo vaco este oficio por muerte del señor justicia Lanuza y señor Pérez Manrrique y se halló que en las vacantes de este oficio juran los lugartenientes en la misma conformidad que presidiendo el señor Justicia y en la misma, a 30 del dicho, juraron dichos lugartenientes en poder del señor abad con protesto, como consta en el registro de actos comunes».

555 J. Á. Sesma (1977), pp. 250-261: «Defensa de las Generalidades: protección del arrendador y sus oficiales». 
pública del reino), libros de cuentas y encautes, cabreos de los censales, libros de intimas de censales y ápocas de ellos.

De la amplia jurisdicción de los diputados sobre cualquier delito económico y penal contra la hacienda del reino, incluidos sus oficiales, se derivarán diversos tipos documentales también custodiados en el archivo del reino. Así, los procesos civiles de fraudes, ejecuciones y ocupaciones serán el testimonio documental de unas prerrogativas judiciales ejercidas por los diputados en una materia de su estricta competencia.

No obstante, además de estos procesos, existieron los denominados procesos de sumarias informaciones, verdaderas relaciones de noticias conducentes a la acusación de un sospechoso de haber infligido un daño a la hacienda o los oficiales del reino. En realidad, eran noticias que se encargaba de redactar una persona comisionada por la Diputación, a modo de agente de información judicial, con vistas a recopilar el mayor número de datos que permitiesen finalmente acusar al posible infractor de un delito contra la gestión del impuesto aduanero.

Paralelamente a la génesis de esta tipología documental de carácter económico, se suscitó, al igual que con el resto de documentos custodiados en el archivo del reino, la necesidad de su consulta. A fin de cuentas, los particulares también participaban en la hacienda del reino a través de la compra de censales sobre las generalidades. Era preciso llevar un cómputo correcto y actualizado de los nombres de los ciudadanos que participaban con mayor o menor cantidad de dinero en la hacienda, mediante los registros documentales, concebidos en este caso no tanto como instrumentos de poder como de garantía de un derecho. En los casos concernientes a la administración de justicia también se observa la consulta de los procesos, entendidos éstos como el reflejo y la constancia documental de una actuación judicial llevada a cabo por los diputados. Así sucedía el 7 de junio de 1612, cuando los diputados deliberaron que se subiera al archivo y se sacara el proceso incoado contra Juan Pérez de Almazán, señor de Maella, y contra Alonso Fernández de Espinosa, arrendadores de las generalidades:

Y juntamente con mi, dicho notario subieron a la sala Real y llegando a la puerta de dicho archiu, hallamos aquella estar bien y fielmente çerrada [...] y entrados allí, dentro del almario intitulado de viedas y execuciones de la legarza primera, super execucionibus, sub literis, a 6 etc., y se sacó un proceso intitulado processus illustres dominos dipputatis Regni Aragonum, contra don Joa- 
nem Pérez de Almazán, super execucione y habiendo sacado dicho proceso, sus señorías bolvieron a salir de dicho archiu y mandaron cerrar y de hecho fueron cerradas las puertas dél, ex quibus, etc. ${ }^{556}$

\subsection{El valor de lo escrito para la historia y la propaganda del reino}

Por quanto el ofiçio de coronista ha sido y es tan útil y necesario para las cossas memorables deste Reyno no queden en perpetuo olvido para lo qual se erigió el dicho oficio [...]. . $^{57}$

Que los cronistas de Aragón consultaron durante los siglos XVI y XVII los documentos custodiados en el propio archivo de la Diputación para fundamentar sus construcciones históricas no ofrece duda. Incluso algunos de ellos fueron reputados conocedores de su contenido y disposición, llegando a ejercer ocasionalmente tareas de organización documental, elaborando «índices», reorganizando las series documentales y, naturalmente, copiando y extrayendo (toda vez que se les franqueasen las puertas del archivo, circunstancia que no siempre sucedía con la agilidad que deseaban) las noticias necesarias para sus obras. De hecho, al acceder no sólo a la consulta sino también a la ordenación del archivo, podría pensarse en la culminación de un cursus honorum del cronista oficial del reino, en el que el historiador se convierte en escritor-archivero y penetra en el corazón de la memoria del reino con la intención de consultar para escribir y organizar, como hemos expuesto al analizar la figura del archivero. ${ }^{558}$

Esta relación entre cronista, archivo y servicio al reino de Aragón se ponía de manifiesto en el memorial que Juan Francisco Andrés de Uztarroz envió a los diputados para que éstos le facilitasen su labor de inventario de escrituras tocantes a la historia del reino, habida cuenta de que «en 26 de octubre del año 1646, el braço de las universidades deliberó que se dé nombre y

556 Registro de actos comunes del año 1612, A.D.P.Z., ms. 323, f. 226v-228r.

557 R.A.H., ms. 11/7946.

558 Esta idea la ha sintetizado F. Bouza (1998), p. 46: «Así, en el siglo XVII, poco a poco, el archivo se fue convirtiendo en el símbolo del paso a la posteridad también para los autores, una especie de última meta de los hombres de letras que habían vivido por la escritura, de la que el archivo es su consumación, a veces, en grado mayor que la biblioteca». 
título de coronista de este Reyno al doctor Juan Francisco Andrés, para que desde luego, travaje en la continuación de las historias de este Reyno y assí mesmo, quede nombrado dicho doctor Andrés para componer los papeles del archibo, poniéndolos en orden con el inventario, claridad y noticia que conbiene y se le den cien libras jaquesas de salario en cada un año de las generalidades del Reyno». ${ }^{559}$ Años más tarde, el hecho de que el arcediano Diego José Dormer (cronista desde 1677) subrayase el sólido conocimiento que poseía de los documentos custodiados en el archivo de la Diputación, da también buena prueba de esta interrelación, ya que «los papeles del Archivo [del reino de Aragón] los tiene muy vistos y assí muchas vezes suelen los señores diputados llamarle para buscar y reconocer algunos». 560

Sin embargo, detrás de todo el entramado de organización y consulta documental subyace una metodología de trabajo histórico desarrollado por los historiadores oficiales del reino de Aragón que culminaría en la redacción de sus obras. Es cierto que Jerónimo Zurita visitó archivos, coleccionó innumerables manuscritos, formó en definitiva un gran acervo documental empleado para la construcción de sus Anales. ${ }^{561}$ Pero también lo hicieron los sucesores del secretario, ocupándose de pedir los permisos necesarios para acceder a Simancas así como a los archivos y bibliotecas de monasterios, concejos, secretarías, etc. Sólo como muestra debe destacarse la colección documental recopilada por el citado Dormer. ${ }^{562}$ En su «Informe sobre que el coronista del Reyno de Aragón no puede continuar los Anales de su corona, sin reconocer los Reales Archivos, y otros puestos donde se hallan las noticias que se requieren para obra de esta calidad», subraya que para elaborar su obra historiográfica

559 R.A.H., ms. 9/548, f. 316.

560 B.N.E., ms. 8380, f. 210r.

561 Fernando Bouza Álvarez (1998), pp. 47-48: «Aunque el historiador no visite en exceso los archivos —el aragonés Jerónimo de Zurita constituye una de las excepciones más cualificadas-, sí que va a formar su propia colección de materiales sobre los que basar su posterior trabajo narrativo, es decir, creará su propio archivo para su particular obra»; F. Bouza (1999a), p. 95: «Pese a esta proyectada vinculación de Simancas con la tarea histórica - tan ligada por otra parte, con los libros de excerpta que debían componerse en las bibliotecas-, los fondos depositados en el gran archivo castellano no fueron muy utilizados por los cronistas de la época, excepción hecha, como es sabido, del aragonés Jerónimo Zurita".

562 Fernando Bouza Álvarez (1998), p. 48: «En el siglo XVII se logra el máximo desarrollo de estas colecciones creadas por historiadores para poder escribir más tarde la historia de su tiempo sobre las pruebas que dichas colecciones les aportaban». 
Ha hecho de su parte el Doctor Dormer lo que ha podido, procurando instruirse en las más noticias, aviendo recogido muchos originales y papeles manuscritos, de que ha puesto más de trecientos y veinte tomos los más en folio en la Diputación y se contienen en ellos sumarios de los registros de cortes, de actos comunes y de cartas del consistorio y de las respuestas y de los registros de la ciudad de Zaragoça y diversas escrituras de casi todos los archivos del Reyno y cerca de trecientas más en pergamino y cantidad de monedas romanas, godas y de todos los reynos de España y otros, sin tenerle todo esto gasto alguno al Reyno [...]. ${ }^{563}$

Es fundamental, en este sentido, hacer un breve apunte acerca de las motivaciones que el poder desplegado por el consistorio de los diputados va a desarrollar para defender el ordenamiento jurídico del reino. Defensa y no oposición ni instrumentalización violenta de las libertades aragonesas fue el argumento general esgrimido por la Diputación a lo largo de su dilatada existencia para fortalecer la foralidad, a pesar de los acontecimientos de $1591 .^{564}$ En este sentido, no resulta original acudir al recurso a la imprenta como medio para dar a conocer con rapidez y amplitud un mensaje escrito. La Diputación se valdrá de ella con mayor intensidad en estos siglos para llevar a cabo uno de sus más altos cometidos, irrenunciable y consustancial a la propia esencia de la institución, pues, como ya hemos subrayado, «su actuación está basada en cumplir y hacer cumplir los fueros y libertades del Reino». ${ }^{565} \mathrm{Si}$ a lo largo de otras páginas hemos descrito el proceso general que impulsa a la Diputación a encabezar la garantía del respeto a las singularidades forales aragonesas, nos interesa ahora destacar cómo su defensa se va a centrar en diversos mecanismos de propaganda cultural, esencialmente a través del encargo, publicación y pago de las tareas de impresión de un importante número de obras canalizadoras de la producción historiográfica y jurídica aragonesa. ${ }^{566}$ De hecho, se percibe una

563 B.N.E., ms. 8380, f. 292r. En el colofón de este informe: «En Zaragoça a 8 de noviembre de 1684 ».

564 "This theory was not formulated using the term "resistance" but as a defence of the fueros and liberties»: Javier Gil Pujol (1997), pp. 160-187. Recogido por Jesús Gascón Pérez (1997), p. 473.

565 J. Á. Sesma (1977), p. 31.

566 Una selección de estos trabajos (mapa del reino de Aragón del cosmógrafo Juan Bautista Labaña, Ceremonial de Ibáñez de Aoiz, etc.), en la introducción de J. A. Sesma y J. A. Armillas a la obra de Lorenzo Ibáñez de Aoiz, Ceremonial y breve relación..., p. 15. Para analizar la motivación del encargo de los diputados al portugúes Labaña con el fin de elaborar el mapa de Aragón, vid. Agustín Hernando (1996). 
progresiva equivalencia entre poder institucional y conciencia aragonesa. Los cauces que la Diputación va a emplear para cumplir con su cometido y a la vez reforzar el sentimiento aragonés van a tener en la producción bibliográfica nacida del consistorio una de sus más genuinas expresiones. ${ }^{567}$

La convivencia simultánea del archivo y la librería del reino de Aragón durante la época moderna es un claro ejemplo del "poder de lo escrito» en un ámbito político institucional tan particular como el aragonés, donde el recurso al valor de las manifestaciones de la escritura por parte de la Diputación va a ser una constante desde mediados del siglo XV hasta comienzos del siglo XVIII. ${ }^{568}$ El primer nexo de unión entre el depósito bibliográfico y el archivístico lo encarna el propio edificio donde tuvo su sede la Diputación del reino de Aragón. Como se ha señalado, en el interior del palacio de la Diputación se encontraban varios depósitos documentales de naturaleza distinta. En efecto, en la segunda planta se custodiaron el archivo del reino y el de la bailía y maestre racional. ${ }^{569}$ En otras dependencias se hallaban el archivo de la Real Audiencia y también el de la cancillería. El denominado «archivo alto» no era sino el almacén de los libros impresos por orden de los diputados, entre los que se encontraban las impresiones de los Anales del cronista del reino, diversas obras de contenido jurídico, los repertorios de fueros de Aragón, etc. ${ }^{570}$ Estos depósitos documentales van a estar a lo largo de la Edad Moderna al servicio de la institución que los gestiona (la Diputación) en la conjunta significación de documentos como instrumentos de gobierno, de la administración y de la historia y refuerzo propagandístico del reino, a través de un importante programa institucional de encargos de obras de ilustres juristas, cronistas, letrados encargados de la organización de los documentos del archivo, etc.

La nómina de cronistas oficiales, sobre todo a partir de Zurita, va a situarse en el ojo del huracán de las actividades apologéticas desarrolladas

567 J. Á. Sesma (1987a). Manuel J. Pedraza (1993), docs. 493, 521, 527, 528, 529, 541, 562 y 1002, y (1997), pp. 156-157.

568 J. L. Rodríguez de Diego (1998b), p. 519: «Esta simultaneidad temporal y espacial de archivo y biblioteca esconde otra identidad mucho más profunda, de la que aquélla en definitiva es consecuencia: el poder de lo escrito». F. Bouza lo ha sistematizado perfectamente en su trabajo Del escribano a la biblioteca (Bouza, 1992, pp. 71-107): «La escritura y el poder del príncipe».

569 Diego Navarro Bonilla (2000b).

570 Diego Navarro Bonilla (1998a). 
por el reino y las propagandísticas a cargo de los oficiales reales. El primer cronista sucesor del secretario Zurita, Jerónimo de Blancas, ilustra cómo en pleno siglo XVI, arreciando cada vez con mayor intensidad la compleja relación Monarquía-reino, la política reivindicativa aragonesa se vale de la obra historiográfica para magnificar el pasado aragonés. ${ }^{571}$ No es casual que su obra esté dedicada a quienes han hecho posible su publicación en 1588: los diputados del reino de Aragón, defensores de la «inviolable cultura foral». ${ }^{572}$

A pesar de las contundentes opiniones vertidas sobre sus Aragonensium Rerum Commentarii, que permiten calificar a Blancas de «apologeta del fuerismo reivindicativo», ${ }^{573}$ lo cierto es que su libro «se trata sobre todo de un intento, más o menos logrado de fijar y sostener un pasado discutible, pero indiscutido hasta entonces, en el supuesto de admitirse unos principios básicos de doctrina jurídica, política y nobiliar, a través de unos orígenes fabulados que debían engrandecer el protagonismo de Aragón en la política española de su tiempo». ${ }^{574}$ Cuestión más problemática y no por ello menos apasionante, es procurar analizar la vinculación entre producción histórica aragonesa y consolidación de identidad colectiva. Esta «conciencia nacional aragonesa» pudo ser perfectamente animada desde el seno de la Diputación del reino de Aragón a través esencialmente de la delimitación del territorio perfilada por motivos fiscales y la defensa activa de éste, el mantenimiento de sus estructuras institucionales y el sentimiento de orgullo por la pertenencia

571 Como constante seguida por los cronistas de Aragón, también Blancas accede y consulta los documentos del archivo del reino. Felipe Mateu Llopis (1944), p. 19: «En 20 de julio de 1585, Blancas dedicaba a los cuatro brazos del reino su obra titulada Modo de proceder en Cortes de Aragón, para la que había utilizado los registros del archivo de la Diputación».

572 Guillermo Redondo Veintemillas, en su introducción a la edición facsímil de los Comentarios de las Cosas de Aragón, Zaragoza, Cortes de Aragón, 1995, p. 18: "Precisamente ahí se debe situar el esfuerzo de nuestro cronista por sintetizar y destacar todo cuanto hacía de Aragón y de sus instituciones un reino independiente, con un pasado antiguo y rico que no quería perder su idiosincrasia y su respeto histórico, basado en los esplendores de su pasado y de sus instituciones ejemplares, para momentos en los que el centralismo y predominio felipista amenazaba la propia supervivencia de Aragón y de sus fueros y libertades, tenidas como sagradas, enraizadas y además, irrenunciables».

573 Ernest Belenguer Cebriá (1996), p. 112.

574 Guillermo Redondo Veintemillas, en su introducción a la edición facsímil de los Comentarios de las Cosas de Aragón, p. 20. 
a la comunidad aragonesa que proyectaba un pasado común y glorioso. ${ }^{575}$ No insistiremos más en el interesado interés y apoyo a la «estructura de lo escrito" como elementos primarios necesarios para consolidar $\mathrm{y}$ fomentar las excelencias de la pertenencia a la colectividad sociopolítica aragonesa.

Desde el ámbito de la producción historiográfica, el poder del escrito histórico más o menos apologético pero indudablemente alentado por las instituciones aragonesas no fue sólo una evidencia para los propios poderes que lo favorecían y promovían. Con mucha discreción, los representantes del monarca en Aragón jugaban sus bazas para intentar, en la medida de lo posible, controlar esta vía de escape de la propaganda política y cultural aragonesa. De hecho, lo sucedido en 1591 gravitaba poderosamente sobre las mentalidades, y las enseñanzas de los acontecimientos recientes requerían un mayor control de la producción escrita que saliese de Aragón. ${ }^{576}$ En la carta escrita por el fiscal del rey Martín Miravete de Blancas al regente del Consejo de Aragón Martín Batista de Lanuza, se estudiaba la necesidad de elegir adecuadamente tanto al sucesor del cronista Juan Costa, fallecido en 1597, como al censor encargado de controlar sus escritos. ${ }^{577}$ Estos dos ministros acudían al símil que identificaba al

575 J. Á. Sesma (1987a), p. 258.

576 No en vano, el freno al poder de los escritos aragoneses por parte de Felipe II tuvo una de sus más inmediatas consecuencias en el fuero promulgado en las Cortes de Tarazona de 1592, epílogo de las alteraciones de 1591: «De la prohibición de imprimir: El abuso que hasta aquí ha havido de imprimir cada uno por su voluntad es muy dañoso a la República y ocasionado para salir a luz libros que no convengan ni para el servicio de Dios, ni para el bien del Reyno. Por lo qual su Magestad, de voluntad de la Corte estatuye y ordena que los que sin licencia expressa de su Magestad y de sus successores o del que presidiere en la Audiencia Real deste Reyno imprimieren libro o papel alguno tengan perdidos la impressión, los libros, moldes y papeles, y incurran en otras penas arbitrarias a arbitrio del dicho presidente y puedan ser acusados a instancia del Fiscal de su Magestad y de sus successores en la Corte del Iusticia de Aragón. Y a más de la licencia de su Magestad, y de sus successores, haya de intervenir e intervenga la del Ordinario. La qual sola baste para iubileos, indulgencias y otras cosas tocantes al govierno». Savall y Penén (1866), vol. 2, p. 439.

577 R.A.H., ms. 9/548, f. 492r-492v: «Carta del fiscal don Martín Miravete de Blancas a don Martín Batista de Lanuza, regente del consejo de Aragón, sobre la provisión del oficio de coronista deste Reyno por muerte del coronista micer Juan Costa». [Zaragoza, 18 de junio de 1595]: «Ha muerto el dotor micer Costa, coronista deste Reyno, y assí havrá de proveerse este oficio por los diputados. Vuestra Merced vee lo que importa al servicio de Su Majestad y alteza que la persona a quien se huviere de encomendar este ministerio tenga el zelo de su servicio, grabedad y prudencia que se requieren en el que ha de ser censor de sus obras». Recogida por J. Á. Sesma y J. A. Armillas en la introducción a la obra de Lorenzo IbÁÑEZ De AOIZ, Ceremonial y breve relación..., p. 17. 
historiador, que tenía en sus manos la posibilidad de ensalzar o erosionar la figura del rey mediante su producción historiográfica, con un moderno Pigmalión: «Que si la fama dixo Séneca que la tenían Liberrimum Principem iudicem, ésta la esparcen los Historiadores y la pintan y hazen a su gusto como Pygmaleón con su muger». ${ }^{578}$ Era, por tanto, imprescindible ejercer control sobre las obras de estos autores, pero intentando una medida de anticipación: elegir a la persona adecuada al servicio del monarca.

Este intento de injerencia del fiscal Miravete de Blancas llegó al extremo de solicitar por medio del virrey de Aragón a los diputados que entregasen al representante del monarca en Aragón los manuscritos de Costa sobre las Cortes celebradas en 1585 . No cesó ahí el intento de controlar estos documentos del cronista, ya que este oficial real quiso consultarlos dentro del archivo, con toda la discreción posible («assí mismo, deseé buscar ocasión para verlos sin ruido, porque si al descubierto se les pidieran estos papeles, no parece que se conseguía el servicio de Su Majestad por el cuidado que mostraría esta diligencia»). Era preciso, alentados sin duda por la política de Felipe II con respecto a los documentos de Estado, controlar «los papeles», ya que su instrumentalización por manos antifelipistas podía socavar molestamente la figura del monarca: «en este punto se nos ha muerto el historiador y con que la nominación que se huviere de hazer sea a propósito, estará todo hecho y Su Majestad podrá quedar servido en lo venidero y caerán en buenas manos los papeles pasados». ${ }^{579}$

Además, la misiva de Miravete de Blancas esbozaba un sibilino plan para entorpecer o al menos retrasar el nombramiento de un nuevo cronista por parte de los diputados, hasta que se encontrase un candidato idóneo para los intereses del monarca: "[el conde de Chinchón] ${ }^{580}$ y vuestra merced verán lo que convendrá al servicio de Su Majestad, que aunque sospecho se han de dar los diputados priesa en proveer este oficio, procuraremos entretener hasta que vea Su Majestad si será servido de que se les

578 Ídem.

579 Ídem.

580 Recordemos que don Diego Fernández de Cabrera y Bobadilla, tercer conde de Chinchón, había encabezado una evidente postura contraria al reino de Aragón durante todo el período de las alteraciones. No es de extrañar que su nombre figurase en esta carta del fiscal en un claro intento de controlar la reivindicación aragonesa desarrollada mediante el poder de la palabra escrita. Vid. J. Á. Sesma y J. A. Armillas en su introducción al Ceremonial y breve relación..., pp. 15-17. 
proponga alguna persona de quien se pueda tener entera satisfación. Mui a propósito creo que sería el dotor Baylo, ${ }^{581}$ pues su Magestad le tiene en su servicio y enbarazarle ha poco el cargo que le dio de la librería del Escurial. Vuestra Merced lo verá todo».582

Indudablemente, la enrarecida situación originada por los acontecimientos de 1591-1592 favorecía el ejercicio del control sobre los cronistas del reino. De allí se derivó su utilización como elementos combativos por medio de la palabra escrita, al servicio de intereses de naturaleza política reivindicativa o, en el caso contrario, limitadora de las prerrogativas aragonesas. ${ }^{583}$ La carga política y de defensa del reino a través de los escritos de los cronistas alcanzó su máxima intensidad en los primeros años del siglo XVII. Como colofón a la actividad desarrollada por el consistorio de los diputados en favor y defensa del reino por medios canalizados en los testimonios escritos, rescataremos la opinión de José Antonio Armillas, para quien «la Diputación del Reino desarrolla un intenso esfuerzo de promoción exterior de Aragón, sentando las bases de una auténtica campaña publicitaria de carácter puramente revisionista y destinada a borrar la mala imagen de los aragoneses [...]». ${ }^{584}$ En cierto modo, conforme la presión antiforalista de la Monarquía se hizo cada vez más efectiva, la Diputación

581 Martín López de Bailo fue el candidato propuesto por el Consejo de Aragón.

582 R.A.H., ms. 9/548, f. 492r-492v.

583 La historiografía del conflicto aragonés está magníficamente estudiada por Jesús Gascón Pérez (1995), pp. 26 y 29. En concreto, y sólo como pequeña muestra, se deben subrayar los libros de cronistas como Vicencio Blasco de Lanuza, quien en sus Historias Eclesiásticas y seculares intentó "cantar las glorias de Aragón y defender su honra y fama de plumas malintencionadas, en especial de la del cronista castellano Antonio de Herrera [...]». Por su parte, el castellano Gonzalo de Céspedes y Meneses consiguió la aprobación y el aplauso institucional tanto del concejo de Zaragoza como de la Diputación al dar al impresor del reino su Historia apologética en los sucesos del Reyno de Aragón y su çiudad de Çaragoça [...].

584 J. Á. Sesma y J. A. Armillas (1991), pp. 140 y ss. La introducción de estos dos autores a la obra de Lorenzo Ibáñez de Aoiz, Ceremonial y breve relación..., p. 14, también incide en esta circunstancia de producción escrita dirigida en buena medida a restituir la mala imagen del reino tras los acontecimientos de 1591: "En aquellas décadas se vivía en el Reino de Aragón un doble esfuerzo de promoción ad intra y ad extra de las peculiaridades aragonesas, como reacción a la mala opinión creada sobre los aragoneses por los sucesos de 1591». Esta idea también es defendida por Javier Gil Pujol (1991b), p. XIV: «una nueva cultura política aragonesa, que, nacida de una dolorosa reflexión histórica sobre el pasado reciente y preocupada por restañar sus heridas, iba abriéndose camino entre los grupos dominantes del Reino; una cultura política que entendía que la fidelidad a la corona proclamada en los tratados sobre 1591 debía mostrarse igualmente en la práctica gubernativa en el Reino». 
puso más interés en oponer varias líneas de resistencia a los agravios contra los fueros, y la producción historiográfica y jurídica auspiciada por la institución fue un recurso documental ensayado hasta la extinción total del ordenamiento particular aragonés en $1711 .^{585}$

En suma, el análisis del archivo del reino de Aragón es perfectamente abordable desde una triple integración de funciones. Si el archivo es siempre un instrumento del poder, es forzoso concretar las manifestaciones de ese poder en el seno de la Diputación. Los valores de patrimonialidad, así como la alta consideración proyectada sobre la memoria escrita del reino, permiten ahondar en la estima de los diputados por su archivo. Las atribuciones conferidas a la Diputación, esencialmente a través de las reuniones de Cortes, se basan en sus estadios más funcionales en la organización y custodia de los documentos emanados en el transcurso del ejercicio de sus competencias y atribuciones, tanto de gobierno como de administración económica y judicial. En este sentido, la gestión de la hacienda del reino es eficaz si paralelamente existe una estructura administrativa y documental hábil y coherente. Indudablemente, la memoria escrita del reino se convierte, junto a estos valores directos, en un instrumento indirecto de utilidad notable para la construcción historiográfica. En el caso de Aragón, ésta se revistió de un carácter singular, conducente en última instancia (con mayor o menor grado de virulencia) a defender mediante los textos de los cronistas y juristas de Aragón el particular ordenamiento jurídico del reino, representado genéricamente por los fueros y las libertades aragonesas.

\subsection{El valor del archivo en el siglo XVIII para la Monarquía}

Durante los siglos XV al XVII, el papel de defensa del ordenamiento jurídico aragonés fue desempeñado por la Diputación del reino. Hemos

585 Gregorio Colás Latorre y José Antonio Salas Ausens (1982), pp. 538-539: «A lo largo de estos años, la monarquía había conseguido con frecuencia imponer su voluntad sobre los Fueros y en muchas ocasiones más los había pasado por alto, infringiendo las leyes del Reino que por su juramento estaba obligado a respetar. Estas sucesivas transgresiones de la legalidad habían ido radicalizando los ánimos de ciertos sectores de la población aragonesa. La Diputación tampoco fue ajena a este cambio. Cuando componentes de estos sectores radicalizados formen parte del consistorio, opondrán una mayor resistencia a determinadas decisiones del monarca». 
visto cómo los diputados, conscientes de las potencialidades del testimonio escrito, alentaron una política cultural de primer orden tendente a la defensa de la foralidad, además de por los medios tradicionales de naturaleza política y diplomática, recurriendo al valor de la escritura y su difusión mediante la imprenta. Una vez suprimida la Diputación junto con el resto de las instituciones forales en 1711, los funcionarios borbónicos a quienes se encargó la misión de diseñar las nuevas estructuras políticoadministrativas del reino de Aragón acudirían de nuevo a la documentación custodiada durante siglos en el palacio de la antigua Diputación y, desde entonces, sede de la Real Audiencia borbónica. ${ }^{586}$ La conciencia del valor de la documentación como instrumento para argumentar decisiones de naturaleza reorganizativa fiscal o política a comienzos del siglo XVIII tenía en el reino de Aragón un ejemplo de una corriente mucho más extensa y rastreable a lo largo de la literatura especializada, que daría como consecuencia una profunda revisión en torno a la organización, custodia y descripción de los documentos archivísticos. ${ }^{587}$

La memoria escrita de más de dos siglos y medio de pervivencias forales descansaba en los cajones del archivo del reino, algo que para la administración borbónica no pasó inadvertido. ${ }^{588}$ Este patrimonio documental, y muy especialmente las series de naturaleza económica, suponían una base jurídica documentada sobre la que asentar un nuevo sistema fiscal en Aragón. En resumen, continuó en el siglo XVIII el interés por los fondos de la antigua Diputación, y en particular por los documentos de naturaleza

586 Antonio Castillo (1997), pp. 253-255: «El archivo va dejando de ser la acumulación desordenada de los documentos, guardados celosamente en un arca cerrada bajo varias llaves, para convertirse en un conjunto de piezas dispuestas con mayor sistematismo, sujetas a una ordenación jerárquica de las mismas en virtud de su categoría diplomática y jurídica. Llegados a este punto, el archivo se nos presenta como la clave de la burocracia política y administrativa. En el arca o en los armarios reside el poder de la memoria escrita».

587 Margarita Gómez (1985). Citado por José Antonio Fernández Flórez (1993), p. 112. Informe de Santiago Agustín Riol al marqués de Grimaldo sobre los papeles de la Monarquía (30 de agosto de 1726), B.N.E., ms. 9995.

588 A.D.P.Z., leg. 755-2: «Papeles que se deven copiar en el Archibo del Reyno; Arancel de cobranza de derechos establecido por la Diputación asta el reinado de Carlos segundo con distinción de las abreviaciones que aia avido. Las instrucciones que formaban los diputados para el govierno y manejo de las aduanas. Los actos de arrendamiento que se hicieron. Copia de la zédula del rey del año de 1707 adjudicando las aduanas a la Corona. Quentas de lo que producían anualmente y el destino que se dava a los valores». 
económica, si bien con otra finalidad que la dominante hasta entonces: servir a la gestión de la institución productora. En realidad, era «necesario razonarlo todo, presentar pruebas fehacientes de los derechos que, desde antiguo, asisten a nuestros reyes en sus reclamaciones. Sólo los archivos, eclesiásticos y civiles, del país, pueden suministrar estas pruebas contenidas en los viejos documentos por ellos conservados». ${ }^{589}$

Entre los funcionarios diseñadores del nuevo sistema fiscal, sobresalieron Tomás Moreno Pacheco, superintendente general en Aragón, ${ }^{590}$ y Melchor de Macanaz, intendente general de Hacienda y fiscal de Felipe V, a quien se atribuye la construcción teórica que legitimó la abolición del ordenamiento foral aragonés. ${ }^{591}$ Sus desvelos para conseguir este fin y el dilatado procedimiento para llevarlo a buen término nos ilustran sobre la constante vigencia del poder desplegado por registros administrativos y crónicas de muy diversa naturaleza, a pesar de la cesura política ocurrida a comienzos del siglo XVIII. ${ }^{592}$ Cuenta Macanaz en su libro que la actividad de consulta documental por él desplegada fue notable, a pesar de que el acceso a los archivos de la antigua Diputación y de la bailía fue entorpecido por aquellos que todavía intentaban conservar alguna pervivencia anterior. ${ }^{593}$ No cesó en su empeño y tuvo que acudir a las obras históricas y jurídicas para desentrañar todo el complejo hacendístico y administrativo aragonés: "Hiciéronse dueños de los archivos del reino, impidiéndome el registrarlos y reconocer en ellos los intereses de la real hacienda y los que el reino repartía y cobraba de los vasallos, ni otro algún derecho, de modo que me vi precisado a estar día y noche examinando sus fueros, actos de

589 Carmen Crespo Nogueira (1964-1965), p. 68.

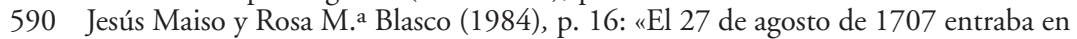
Zaragoza el superintendente general de las finanzas en Aragón, Thomás Moreno Pacheco. La superintendencia es la institución clave para la creación de nuevas imposiciones y para su control exclusivo y directo por parte de la corona. Moreno Pacheco introdujo el papel sellado, puso bajo su control las aduanas y el monopolio del tabaco — anteriormente administrados por la Diputación del Reino-, y se encargó del estanco de la sal».

591 María Dolores Palú Berna (1986), pp. 169-172.

592 Sobre Melchor de Macanaz y su estancia en Zaragoza, es muy interesante la consulta de la reciente edición de Carmen Martín Gaite (1999), pp. 183-205.

593 Melchor de Macanaz (1879), p. 201: «Los aragoneses movieron todos cuantos resortes pudieron para no perder el manejo de las rentas, ya suponiendo que el mantener la antigua Diputación del Reino era de gran utilidad a los intereses del Rey, ya con otros mil pretextos aparentes $[\ldots]$ ». 
las cortes y autores aragoneses que habían escrito sobre las rentas, para ver de dar algún paso en el reglamento de tales rentas». ${ }^{594}$ Los reparos puestos a la consulta a los documentos del reino de Aragón le obligaron a trazar un plan alternativo que sintetizó en un horario de trabajo ininterrumpido y tal vez sobredimensionado:

No por esto dejé de continuar mis trabajos para acabar de apurar la verdad de los fabulosos fueros de los aragoneses. Desde las cuatro de la mañana a las siete despachaba los pleitos y todo lo tocante a la Intendencia y tropas, si todo este tiempo era necesario; de siete a once trabajaba en los fueros; de once a doce oía misa en mi oratorio y daba audiencia; desde la una y media a las cuatro iba a recorrer los trabajadores del paseo y de las cuatro hasta las nueve de la noche volvía a trabajar en los fueros, aumentando siempre a lo ya hecho. ${ }^{595}$

En definitiva, se apuraban los ministros de la Monarquía borbónica por completar la centralización política y administrativa acudiendo a elaborar razonadas construcciones teóricas que justificasen el nuevo sistema, que en el caso concreto de Aragón cristalizaron en la derogación del ordenamiento foral. ${ }^{596} \mathrm{El}$ recurso de Macanaz a la historiografía del reino (especialmente a Zurita) era la consecuencia del proceder regalista que contraponía el estado del gobierno de Aragón en la época de unión de los Reyes Católicos a la progresiva acumulación de prerrogativas del reino, en detrimento de los derechos de la Monarquía en Aragón. ${ }^{597}$ En todo momento se pretendía justificar la autoridad absoluta del rey en todos los territorios de su monarquía, eliminando el anterior planteamiento que sustentó el ordenamiento foral. Muy atrás quedaban por tanto las tesis proaragonesas defendidas por Jerónimo de Blancas a fines del siglo XVI.

La continuidad del interés por la consulta de los documentos de las instituciones extintas obligó al intendente de Aragón, de quien ahora dependía el archivo del reino, a tomar medidas tendentes a mantener su conservación y organización, a ordenar la expedición de certificaciones por el archivero del reino y a regular las consultas con finalidad de investiga-

594 Ibídem, p. 203.

595 Ibídem, p. 217. En cualquier caso, el reflejo de los intereses históricos y jurídicos se aprecia en la biblioteca de Macanaz: María Dolores García Gómez (1998).

596 Jesús Morales Arrizabalaga (1986).

597 M. D. Palú Berna (1986), p. 170. 
ción histórica. Como muestra de la protección demostrada por el aparato burocrático y gubernativo de la Monarquía borbónica por controlar la documentación del reino, se debe hacer referencia a las importantes tareas de organización y descripción documental que fructificaron en el mencionado «Índice de todas las escrituras del Archivo del Reino» elaborado por José de Yoldi en 1749. Pero también la rica información del archivo aragonés seguía surtiendo efectos jurídicos y resolviendo cuestiones suscitadas ante los nuevos organismos. A tal efecto, las peticiones de documentos, copias y certificaciones dirigidas al archivero responsable del fondo de la Diputación, muestran el valor del testimonio escrito años después del cese de la producción documental de la institución aragonesa. Como ejemplo, el marqués de la Fresneda solicitaba en abril de 1754 al archivero Pedro Lezaun un conjunto de escrituras que debían copiarse en los siguientes términos: «Conviniendo sacar del archivo del Reino que está al cargo de vuestra merced copias de los papeles expresados en la nota adjunta, lo participo a vuestra merced a fin de que desde luego se dedique a separarlos y tenerlos promptos para ponerlos de manifiesto a la persona que havisare a vuestra merced a su tiempo. Dios guarde a vuestra merced muchos años. Zaragoza, 4 de abril de 1754. Besa las manos de vuestra merced su mayor servidor El marqués de la Fresneda». ${ }^{598}$ La naturaleza económica de la documentación resulta evidente, ilustrando así la idea de que el archivo del reino constituyó durante el siglo XVIII un recurso archivístico de primer orden para desarrollar el plan de reorganización administrativo y fiscal llevado a cabo por el gobierno borbónico.

La destrucción del archivo en 1809 privó al poder de una fuente inagotable de pruebas documentales necesarias para la organización fiscal, administrativa y gubernativa del antiguo reino. Pero también la investigación histórica se vería resentida por la pérdida parcial del archivo. Una vez finalizado el conflicto bélico, se seguía apelando a la información contenida en el antiguo archivo, del que se conocía su interés y valor en 1815 únicamente por referencias, habida cuenta de que seis años antes había quedado desperdigado, aunque no perdido ni totalmente abandonado. De nuevo se acudía al valor de la información documentada para garantizar, una vez más, derechos y prerrogativas reales en materia de patrimonio real.

598 A.D.P.Z., leg. 755-2. 
Con este motivo, el intendente de Aragón revisó la antigua documentación para certificar qué posesiones aragonesas pertenecían al patrimonio regio. A tal efecto, se solicitaron los permisos necesarios para revisar los documentos que indicaran la antigüedad de las posesiones del rey en Aragón. El depósito que podía suministrar buena parte de las informaciones requeridas era el archivo del reino, arruinado tras el incendio: «ofició a todas las autoridades para que se le franqueasen los archivos y vio con sentimiento que el llamado del Reyno fue reducido a cenizas en el segundo sitio de la ciudad por las tropas francesas, sin haverse podido salbar papel alguno; que la yntendencia conserbó algunos y entre ellos resultaron que las fincas pertenecientes a Su Majestad son: el castillo de la Aljafería [...] Las Casas llamadas de la Diputación, en que existió la Audiencia y están quemadas por el estrago de una bomba sin que haya más que las paredes externas $[. .] »$.

599 Archivo del Palacio Real (Madrid), caja 10955/4. 
APÉNDICE DOCUMENTAL 

1436, Cortes de Monzón y Alcañiz

Acto de corte donde se delimita la función del archivo del reino y el nombramiento del archivero.

Savall y Penén (1866), vol. 2, pp. 215-216.

Y nominacion del Notario, que ha de tener la llave y custodia de dichos archius: el qual no pueda dar traslado, sino con mandamiento, o del señor Rey, o del Rigent el Officio de la Governacion, o del Iusticia de Aragon: y que del archiu de los Actos de la Diputacion, tengan las llaves los Diputados, y del salario del Notario. Assi matex puedan expender, \& fazer expender, en fazer una casa dentro en la Ciudad de Çaragoça en el mas habil lugar que visto les será, de buelta de rejola, en do haya casas distintas, axi matex de buelta de rejola con sus armarios, para tener los processos, actos \& registros de la Cort del Iusticia de Aragon, \& de la Governacion dél, \& de la Diputacion, \& encara fazer copia de bella letra, \& en pergamino, los registros de las Cortes del Regno, \& aquellos sellados, \& signados en pendient, por el Notario de la Cort, en el dito archivo meter, \& cobrar todos los processos, \& registros de la Cort del dito Iusticia, y los que son de los Iusticias passados, do quiere que sian: $\&$ fazer qualesquiere constreylas; \& compulsas, que necessarias seran cerca lo sobredito, \& meter $\&$ fazer meter aquellos en devido siamento, $\&$ con inventario en el dito archivo: De los quales archivos tienga la clau un escrivano, ó Notario apto, honesto, é de buena fama. El qual los Diputados que agora se crean, ó los qui por tiempo serán, eslian agora, \& quando vacará el officio del dito Notario. El qual no pueda dar traslat alguno, sino por mandamiento del Señor Rey, ó del Regente el officio de la Governacion, ó del Iusticia de Aragón. Pero del archivo de los Actos de la Diputación, tiengan \& devan tener las claves los Diputados del Regno. El qual escrivano haya de salario cada un año cincientos sueldos Iaqueses. Los quales se le paguen de las generalidades del Regno por el Administrador de aquellas sin otra cautela. 
Zaragoza, agosto de 1620

Nombramiento del diputado Juan Luis de Sora para comenzar las tareas de reconocimiento del archivo y elaboración de un indice similar al terminado en 1603.

A.D.P.Z., ms. 356, «Registro de actos comunes de 1620», f. 55v-57r.

Eadem die et loco en la sala baxa de las cassas de la Dipputación, estando ajuntados en consistorio en la forma acostumbrada los illustrísimos señores Dipputados en los proxime precedientes actos nombrados sus señorías dixieron que attendido y considerado que por lo mucho que importaba y importa assí para la conservación de los fueros, leyes, actos de cortes y costumbres de la Dipputación, como también para el buen gobierno de la administración de la justicia y jurisdicción de y en el presente consistorio, en el año passado de mil seyscientos y tres, mediante las personas que para lo infrascripto hazer nombraron, hizieron un índize y general rubricario de todos los registros de actos comunes y otros y de todos los documentos, instrumentos, y escrituras, privilegios reales y cartas y otros de consideración tocantes y perttenecientes como está dicho a dicha conserbación y buena administración y por los cuales constava y ha constado y consta de diversos casos y cossas de lo dicho en el presente Reyno succedidas y de las provisiones [?] dello, assí por el dicho consistorio como por su magestad, officiales, ministros y gente del illustrisimo señor Justicia de Aragón y otros tribunales hechas, y assí mesmo de diversos instrumentos, documentos y escrituras tocantes y pertenecientes al universal beneficio y utilidad de hazienda del dicho Reyno. Attendido y considerado assí mesmo que haviéndose offrecido desde la rúbrica [?] de dicho índice y collocación que de todos los dichos registros y papeles según el orden de aquel se hizo y fueron puestos y collocados en sus lugares respectivi sacar del dicho arciu en diversas occasiones y otros registros y papeles que después acá sobre diversas materias han sido hechas y actitadas en el presente consistorio. Los quales han sido: de subirse y ponerse en él con lo que se ha pervertido el orden que justa thenor de dichos índices y rubricario devía guardarse y oy están dichas escrituras, registros y 
papeles fuera de los que están y lugares en que estar devían; attendido y considerado finalmente no hay índice por el qual se hayan puesto en orden los registros y demás escrituras toccantes pertinezientes al dicho Reyno, fecha, dispuesta y actitada respective desde el dicho año mil seyscientos y tres hasta de presente y sea utilisimo, conviniente y necessario desta hazer nuebo índice y las de dicho índice antiguo collocar y de nuebo bolver y restituyr según el orden y forma de aquél.

Por tanto, para todo lo dicho, confiados y satisfechos de la suficiencia, bondad, legalidad, abilidad y buenas partes del illustrísimo señor Joan Luys de Sora, ciudadano de la ciudad de Çaragoça, e su condipputado. Dixeron le nombraban como de fecho le nombraron presente su señoría, que offrezió en quanto ensiera hazer y cumplir todo lo sussodicho y con esto assi mesmo para la aperción hacedera de dicho archiu para continuar en lo sobredicho nombraron al illustre señor Hernando Manuel López de Heredia, infançón condiputado suyo, al qual todas sus señorías lo metieron y dieron sus llabes de dicho archiu para que juntamente con mí, dicho notario, asistiéssemos a la aperción y claussura de dicho archiu, etc. Ex quibus, etc. Testes Pedro López de Quinto y Martín Blasco, Çesarauguste habitantes. 


\section{3 de abril de 1645}

Relación del robo de los registros de la administración de la tabla de Calatayud que el portero Tomás Berges llevaba en Calatayud.

A.D.P.Z., ms. 449, f. 155v y ss.

Los diputados del Reyno de Aragón consultan con los advogados avajo firmados lo siguiente:

Que teniendo vajo su custodia encerrados en un aposento con llabe Thomas Berges, su portero, los libros de la administración de la tabla del General de la ciudad de Calatayud de los años mil seyscientos quarenta y uno, quarenta y dos, quarenta y tres y quarenta y quatro. Los quales con mandamiento de dichos señores diputados recibió y se entregó dellos el dicho portero de poder y manos de Martín de Cassanoba, substituto que dixo ser de Francisco Luis Pérez, tablajero de dicha tabla, sin estar aquel aprobado por el Reyno para dicha administración y teniendo dicho portero dichos libros puestos en unas alforjas en un mesón de dicha ciudad bien custodiados y guardados bajo de llabe, habiéndose salido dicho portero de dicha su posada apenas volbió a ella quando halló que le habían descerrajado dicho aposento y robádole dichos libros y alforjas en que havía muchos papeles y cuentas de importancia. Y esto habiendo sido el día juebes por la tarde que se contaba veinte del mes de abril de este año 1645. Si durante la fragancia de dicho robo pueden los señores diputados proceder a capción de la persona de Francisco Luys Pérez, arriba nombrado de quien se tiene sospecha que ha robado dichos libros.

Respondiendo a lo que en la presente consulta se a propuesto, es regla asentada en fuero que los señores diputados tienen jurisdicción civil para proceder civilmente contra qualesquiere personas que aian frau o espacho en la colecta de los drechos de las generalidades del Reyno y assí respondiendo a lo que se consulta, dijo que los señores diputados civilmente pueden proceder a capción de la persona de Franciso Luis Pérez por haver rovado dichos libros [...]. 
Zaragoza, mayo de 1693

Relación de lo que ocurrió para gastar en ordenar el archivo.

A.D.P.Z., ms. 601, tras f. 25.

El consistorio de diputados interpuso consulta a la corte del Señor Justicia de Aragón para gastar 800 libras de las 5000 en la composición del archivo y papeles del Reyno, expresando en ella haverse combenido con persona que por dicha cantidad se obligava a ello; y satisfaciendo a la disposición foral del año 1592 tit: «de la facultad de gastar los dipputados, fol. 235, col. 3" la firmaron cinco diputados y uno de cada brazo la qual se decretó el día 3 de maio deste presente año. El mismo día 7 en que concedió la corte por su decreto la facultad para poder gastar dichas 800 libras, despachó el consistorio la póliza de ellas contra el arrendador de las generalidades y a favor de Blas Assensio con la advertencia de que éste las havía de entregar a la persona con quien se havía pactado dicha composición del archivo en la forma y manera que se expresaría en la concordia que havía de otorgar el consistorio; reconociendo assimismo dicho consistorio en dicha póliza la necesidad que tenía para su eficacia y valor de estar authorizada con las firmas de cinco diputados, uno de cada brazo y un brazo entero. El día 11 otorgó el consistorio la concordia con don Juan de Audina, y declaró ser éste la persona con quien decía en la consulta que tenía hecho el combenio. El día 19 otorgó Blas Asensio la carta de pago al arrendador de haver rezivido las 800 libras para los fines y efectos contenidos en la póliza.

Destos hechos resulta lo primero: que aunque los diputados arreglaron la consulta a las disposiciones del fuero en quanto a las firmas, número y calidad dellas, no la preservaron del fuero de [?] porque no hizieron en ella memoria ni observaron lo prevenido por el encaute que dejaron los señores inquisidores del tribunal de quentas el año de 1691, para que en el contenido de semejantes consultas se expresasse el estado del patrimonio del Reyno [...] luego no haviendo intervenido por el brazo de universidades sino don Juan de Audina, diputado interesado, no se cumplió en ella con la forma que dispuso el fuero del año 1592. 
Zaragoza, mayo de 1693

Relación de lo hecho en la organización de las escrituras del archivo por parte de José Sagarra, asistente de don Juan de Audina.

A.D.P.Z., ms. 601, f. 176v.

Illustrísimo señor

Josef Sagarra, asistente de don Juan Audina, ciudadano de la ciudad de Caragoça, para la compossición de el archivo, puesto a los pies de vuestra señoría illustrísima dice: que en cumplimiento de el encargo de lo capitulado entre vuestra señoría y el dicho para la composición de los papeles de el archivo de vuestras señorías a executado el contenido de los capítulos de su concordia con las adbertencias, limitaciones y condiciones que en aquélla se expressan; y algunas con el deseo de acertar el suplicante, se han añadido: a saver, es en la dirección de las ligarças de procesos de denunciaciones, informaciones sumarias, biedas de panes y carnes, súplicas, insaculaciones y desinsaculaciones, cabrebaciones de censales, criminales y de cossas del general; esto es, procesos de maçarrón, fraudes, y puniciones civiles que son las telas de procesos que se allan en el archivo, se han reducido a sus ligarças y puestos careándolos en la matrícula en donde están anotados los procesos que faltan de cada una de aquéllas; trabajo el de más cuydado y más peligroso en la permanencia, pues a solas para la conserbación de el estado presente necesita de toda la probidencia de vuestra señoría, y para que a vuestras señorías conste mi desseo en quanto a la duración de lo que se ha trabajado diré abajo algunos puntos de que vuestra señoría eligirá los que le parecieren más al propósito para este efecto y aunque por los pactos de la capitulación no tenía el suplicante obligación de carear ni poner en matrícula más procesos que los actitados desde el año 1600 por reconocer el daño que se siguía de no estar todos en rúbrica por embaraçarse y confundirse las ligarças notificó el suplicante a vuestra señoría esta necesidad y con su permisso en horden hizo nuebas ligarças, se pusieron en matrícula atrasando el horden de dicha matrícula, pues fue necesario en lo que se añadió posponer procesos de el año 1400 al año 1600 , como resultará y constará a vuestra señoría de su inspección. 
Zaragoza, 11 de septiembre de 1693

Nombramiento de Blas Asensio Monterde como vigilante del archivo del reino mientras duren las obras para abrir otra ventana y mejorar la iluminación de su interior.

\section{A.D.P.Z., ms. 601 , f. 54v-55r.}

Atendido y considerado que era necesario para dar luz al archivo principal del Reyno abrir una ventana grande y poner en ella una reja por estar aquél muy obscuro y sin casi podersse leer una carta y haver parecido a dichos illustrísimos señores diputados ser de suma importancia el que dicho archivo estubiese con más claridad y no poder executarse el abrir dicha ventana sin el término de dos o tres días y que asta en tanto que dicha ventana estubiera con su reja, havía de estar abierto dicho archivo. Por tanto, confiando de la fidelidad de Blas Asensio Monterde, portero de la diputación, sus señorías pasaron a nombrarle comisario y asistente en dicho archivo para que guardara y tubiera cuydado especial de todo lo que ay en dicho archivo con cargo de no apartarse ni salir de dicho archivo mientras éste estubiere abierto y hasta que dicha ventana estubiere con su reja, sin que persona alguna pudiera entrar a dicho archivo por dicha ventana. 
Zaragoza, 7 de mayo de 1703

Memorial de Juan Francisco de Audina y Benedid al concluir el segundo indice de los registros de actos comunes de la Diputación del reino, continuación del iniciado por Diego de Espés.

A.D.P.Z., ms. 622.

Hallávame yo uno de los que componían aquel consistorio y de los que intervenían en la Junta Magna, quedó a cuenta de mi confianza este encargo, tan prolixo como útil, pero reconociendo que mi inutilidad y mi salud eran los mayores contrarios que tenía el desempeño de tanta obligación, me valí del doctor Joseph Baltasar Arañón y Lumbier, cuia facilidad en resumir, acierto en notar, cuidado en advertir, vigilancia y memoria en citar, mereció la singular aprovación de los vissores nombrados en años pasados por este illustrísimo Reyno, logrando yo con su asistencia ver mi obligación enteramente cumplida y mi elección bastantemente acreditada. Los consistorios pasados, estimulados de los repetidos encautes de los inquisidores de cuentas, an solicitado adelantar el curso de este índize, pero la positura de las cosas, los negociados de la Monarquía y las precissas ocurrencias a que devía atender el Reyno, an sido el motivo de que por algunos años hubiesse calmado su prosecución, por ser fozoso aiudarse de sus caudales para el cumplimiento de mayores obligaciones. Sólo V.S.I. con el desseo del mayor lustre del Reyno y con su alta dirección a pedido componer términos tan distantes, dispensando las cantidades que se estavan por estos travaxos, dispertando la inescusable pereza en que dormía este índize, y dando la última mano a obra tan importante. Sólos pues V.SS.I. son acrehedores legítimos de que sus nombres authorizen este índize en su principio, pues a imperios del cuidado de V.S.I. y a esfuerzos de su solicitud, deve este índize la última perfección en su fin. Con ella pues, en ombros de los gloriosos nombres de V.S.I. llega al consistorio de V.S.I. con más agradecimientos que sucesos comprehende su dilatado volumen, confesando su mucha gratitud en la pronta obediencia con que espera responder a V.S.I. siempre que V.S.I. gustare servirse de los exemplares que le dan bulto. Dios guarde a V.S.I. en el lustre, estimación y authoridad que V.S.I. mereze y todos los humildes hijos de V.S.I. desseamos. Zaragoza, mayo 7 de 1703.

Besa las manos de V.S.I. su más favorecido y obligado serbidor Juan Francisco de Audina y Benedid. 
Zaragoza, 7 de mayo de 1703

Instrucción sobre el modo de hallar los actos resumidos en el indice de Audina.

A.D.P.Z., ms. 622.

Todos los actos pueden pertenecer a una de tres letras; o a la del nombre del acto o a la del nombre de la materia y sustancia de que trata o a la del nombre de aquel a cuyo favor se despachó. Exemplo: Firma del Señor virrey en caso de haverse hecho un pregón de orden de los señores diputados. Este acto puede estar o en la $\mathrm{F}$ que es la letra del nombre del acto, o en la $\mathrm{P}$ que es del de la materia o en la $\mathrm{V}$, que es la del de la persona a quien se concedió. Y con esto, no parece puede aver dificultad en hallar lo que en este índize se busque. También se an de advertir dos cosas. La primera que en todas las letras antes de resumir el acto primero de aquel año, se pone a la margen de la mano izquierda el año en que sucedió lo enunciado en aquel acto y que assí el acto primero como los demás tienen en dicha margen sus números 1,2, 3, etc. Lo qual sirve para hallarlos con más facilidad quando de unas letras a otras se citan. La segunda, que al fin de cada acto resumido ai tres números y de estos el primero señala el registro de aquel año. El segundo señala el folio del registro donde está el acto resumido. Y el tercero, señala el mismo acto, pues vaxo un mismo folio suele haver en registro muchos actos. Anse dexado al fin de este índize algunas ojas en blanco, a fin de resumirse en ellas veinte registros de la Junta Magna. 
Zaragoza, 25 de mayo de 1703

Acto de entrega del indice de Audina a los diputados del reino.

A.D.P.Z., ms. 618, f. 97r-97v.

Pareció don Juan Baudina y entregó a dichos señores diputados el índece de las cossas memorables que contienen los cien registros de actos comunes de dicha diputación que son los incluidos desde los años mil seiscientos y uno inclusibe hasta el de mil y setecientos y ocho; illustres señores diputados han otorgado ápoca legítima de haberlos recevido conforme a la capitulación otorgada entre dicho illustrísimo reino y dicho don Juan Baudina, y assí mesmo se ha mandado le entreguen dicho índice a dicho don Juan Baudina para poner en él los nombres de los señores diputados que ha visto en dichos cien años para [reconocer?] dicha segunda copia de actos lo que contiene dicho índice y assí mismo dichos illustrísimos señores diputados deliberaron se le entregassen los veinte registros de la junta magna, los quales debe poner en índice dicho don Juan Baudina, conforme dicha capitulación. 


\section{0}

\section{Zaragoza, 4 de noviembre de 1745}

Memorial de Martín Maza de Lizana, incluido en el expediente de provisión de la plaza de archivero de su hijo, Martín Maza de Lizana y Villal$b a$.

\section{A.D.P.Z., leg. 755-3. Publica Diego Navarro Bonilla (1996), p. 213.}

\section{Excelentísimo Señor}

Cumpliendo con el precepto de Vuestra Excelencia y orden que me comunica Don Joseph Sebastián su secretario, en carta de 28 de octubre último, por la que me manda informe a Vuestra Excelencia en qué tiempo se estableció el Archibo del Reyno, que está a mi cargo, con expresión de los papeles de que se compone, y con qué título lo sirvo; Debo hazer presente a Vuestra Excelencia que no se enquentra la primitiba formazión del referido Archibo; y según la antigüedad de los Papeles se reconoze haver tenido principio desde que hay Reyno: este Archibo se halla situado en el Centro de la Audiencia al pie de la sumptuosa Sala de San Jorxe, y sus papeles se hallan mui custodiados y cerrados en unos caxones primorosamente adornados: en él se hallan todos los registros de Cortes zelebradas por los Serenísimos Señores Reyes en este Reyno, Los Quatro Estamentos y Brazos de Cavalleros Nobles, Hijosdalgo, Prebendados y Universidades, Los Registros de Actos Comunes, de todo lo que deliberaban los Diputados del Reyno; Las firmas y despachos de sus Regalías: Los Cabreos de los Cargos y Censales que tiene, ó, tenía contra sí el Reyno: Los Cabreos de las Rentas, drechos y demás Regalías que perzive y tiene el Reyno: Los Libros de quentas de las Rentas que produzían: Los drechos y propios del Reyno, quando los Administraba éste, y las que daba quando estaba por arriendo: Los Actos de Censales que cargaba el Reyno sobre sí, y los de las Canzelaciones y Luiziones que haría de ellos; y los de las ápocas que otorgaban los Acrehedores Censalistas de pensiones y Cargos ordinarios: Los Procesos de las Pruebas que havían las personas insaculadas en los Ofizios y demás empleos del Reyno: Los papeles de los Servicios hechos por el Reyno de los Señores Reyes de Aragón: Los papeles origi[f. 7r.] nales, e, impresos de Historias de los Coronistas del Reyno que 
escrivieron: Las Allegaciones en derecho hechas en los pleitos que siguió el Reyno; ay los Prozesos que fulminaba éste, de varios drechos y assumptos; y ottros muchos papeles, como son: Cartas de los Señores Reyes al Reyno; Privilegios de Noblezas, e, Infanzonías. Este empleo de Archivero de los Papeles de el Reyno, me hallo sirviéndolo, desde que de orden de Su Majestad se extinguió la Junta del Real Erario de Aragón, haviéndome entregado las llaves de él, el Señor Marqués de Castelar, el que haviendo preguntado a los señores de aquélla quien exercía el empleo de Secretario, dixo tenía Orden de Su Majestad para encargarle, con las llaves del Archibo y cuidado de sus Papeles. Los Señores que componían dicha Junta fueron: Por el Brazo de Eclesiásticos el Venerable obispo Asanza que lo fue de León; el de Paula que lo fue de Albarrazín: Por el Brazo de Nobles el Conde de Sanclemente, y el Marqués de Campo Real; y por los Brazos de Caballeros Hijosdalgo, y Comunidades don Jacinto Pérez de Hueros, don Bruno La Balsa, don Juan Antonio San Jil, y don Antonio Ortiz los que con aprobazión del Excelentísimo Señor Prínzipe Tesclaes de Telli Presidente y Caveza de la referida Junta (por ascenso del Secretario don Juan Antonio Lafuente que pasó a la Corte con maior empleo) me nombraron por su secretario cuyo ofizio exerzí el tiempo que permanezió la Junta, y desde su extinción el de Archivero con el orden que de Su Majestad dixo tener el Señor Marqués de Castelar, quando me entregó las llaves que es quanto puedo informar a Vuestra Excelencia en este asumpto, en el que resolverá lo que fuere de su agrado.

Zaragoza y Noviembre 4 de 1745

Excelentísimo Señor Don Martín Maza de Lizana 
Zaragoza, 10 de noviembre de 1745

Informe sobre las aussencias que pide Don Martín Maza para que su hijo sirva el archivo del reyno.

A.H.P.Z., Libro del Real Acuerdo de los informes, consultas y representaciones hechas a Su Majestad en los años de 1745 y 1746, f. 21v-24r.

Señor: en carta de Don Francisco Campo de Arbe de 16 de Octubre último manda Vuestra Majestad a esta Audiencia informe sobre la pretensión de Don Martín Maza de Lizana, en que pide se le conceda la facultad de servir en sus ausencias y enfermedades o la substitución de Archibero del Archibo de este Reyno a Don Martín Maza y Villalba su Hijo: y que exprese la Audiencia en qué parte se halla establecido este Archibo desde qué tiempo y la calidad de los papeles que contiene con la forma de su resguardo y lo demás que estimare digno de tenerse presente en este assumpto y en su cumplimiento dice: Que no se encuentra la primitiba formación de dicho Archibo y según la Antiguedad de sus papeles se conoze haber tenido principio desde que hay Reyno. Este Archibo se halla situado en el centro de la Audiencia al pie de la sumptuosa Sala de San Jorge; y sus papeles se hallan muy custodiados y cerrados en unos caxones primorosamente ordenados: en él se hallan todos los Registros de Cortes celebradas por los Sereníssimos Reyes de este Reyno los quatro estamentos y Brazos de Cavalleros, Nobles, Hijosdalgo, Prebandados y Unibersidades: Los Registros de actos comunes de todo lo que deliberaban los Diputados, las firmas despachos de sus Regalías: los Cabreos de los Cargos y Censales que tiene o tenía cotra sí el Reyno: Los Cabreos de las rentas, drechos y demás regalías que percibía y tenía el Reyno: los libros de Cuentas de las Rentas que producían: los drechos y propios del Reyno quando los administraba éste y las que daba quando estaba por arriendo: los actos de censales que cargaba el Reyno sobre sí; y los de las Canzelaciones y Luiciones, que hacía de ellos: y los de las ápocas que otorgaban los Acrehedores censalistas de pensiones y cargos ordinarios: Los Procesos de pruebas que hacían las personas insaculadas en los oficios y demás empleos del 
Reyno: ${ }^{600}$ los papeles de los Servicios hechos por el Reyno a los Señores Reyes de Aragón: Los papeles originales e impresos de las Historias de los Coronistas del Reyno que escribieron: Las Alegaciones en drecho hechas en los pleytos que siguió el Reyno; y los procesos que fulminaba éste de varios drechos y assumptos y otros muchos papeles como son: Cartas de los señores Reyes al Reyno, Privilegios de Nobleza e Infanzonías. Dicho empleo de Archibero le sirve el referido Don Martín Maza de Lizana desde que de orden de Vuestra Majestad se extinguió la Junta del Real Erario habiéndole entregado las llabes el Marqués de Castelar Intendente que entonces era de Aragón y Corregidor de esta Ciudad en viertud de las órdenes con que dixo se hallaba de Vuestra Majestad desde cuio tiempo hasta de presente ha servido dicho Martín el referido oficio cumpliendo con su obligación, por cuio motibo y el de concurrir en su hijo las circumstancias que se requieren, no se le ofreze reparo a la Audiencia en que Vuestra Majestad le conceda la gracia que solicita: Vuestra Majestad resolverá lo que sea más de su agrado y servicio.

Zaragoza 10 de Noviembre de 1745.

Don Joseph Sebastián

600 Vid. en general Benito Vicente de Cuéllar (1988). Para un caso concreto, vid. igualmente Alberto Montaner Frutos y Diego Navarro Bonilla (1995). 
Zaragoza, 16 de diciembre de 1749

Breve noticia del archivo del reyno de Aragón procedente del inventario realizado por el archivero José de Yoldi

A.G.S., Secretaría y Superintendencia de Hacienda, leg. 539.

Se halla este archivo en las casas que antiguamente llamavan de la Diputación y aora de la Real Audiencia por residir en ella sus tribunales. Está situado en lo interior de la sala llamada de San Jorge, patrón del Reyno. Tiene una sola puerta con tres cerraduras. Es de bronze con diferentes adornos del mismo metal por fuera, y barras de yerro que la aseguran por dentro; su tamaño es de diez palmos de alto y seis de ancho.

Es una sala prolongada de 54 pies de largo y 18 de ancho con una ventana y rexa que toma su luz de la parte del norte sobre el río Ebro y otra en lo más elevado a la parte opuesta. Está fabricada con primorosa arquitectura en su bóveda, lunetos y cornisa; doradas tarxetas y distribuydas las armas de la Corona de Aragón; pintado lo demás con follage de buena mano. Sobre la ventana principal están pintaos en la pared los retratos de los Señores REYES el señor don Carlos Segundo y Señora doña María Luisa de Borbón, sobre ellos el escudo de armas de $\mathrm{Su}$ Majestad y devajo las Barras de Aragón. A los tres ángulos rodean 88 almarios de nogal de una vara en quadro de frente y otra de fondo distribuydos en quatro linias sin contar 22 caxones que sirven de vasa, los que no están numerados, y parece se destinaron para papeles inútiles pero sí los demás con sus tarxetas y rótulos de la clase de papeles que deven contener en la forma siguiente [...]

En medio de la sala hay una mesa grande de nogal con dos caxones cuydadosamente travajados. Al extremo de la sala a mano drecha hay un esgonze muy reducido en que sólo caven tres arcas de quatro palmos de largo y dos de alto, forradas en terciopelo carmesí cada una con tres cerraduras doradas y por los rótulos bordados de oro que hay en los tapes se manifiesta que servían para el sorteo de los oficios del reyno. 
Tiene este archivo por vía de reserva otra sala muy larga en los desvanes de la misma casa, consta de 80 pies de largo y 20 de ancho sin adorno alguno y de arquitectura común; en ella están las impresiones que costeava el Reyno: éstas son las de los fueros, actos de corte, annales de Zurita, de Leonardo, de Sayas, de Panzano, de Blancas y otras de que en el lugar que corresponda se dará puntual notizia.

Zaragoza 16 de deziembre de 1749. 


\section{Zaragoza, 1754}

Memorial del archivero Pedro Lezaun sobre el origen del archivo del reino $y$ contenido del mismo.

A.D.P.Z., leg. $755-4 .^{\circ}$, f. $1 \mathrm{r}-4 \mathrm{v}$.

En las Cortes celebradas en Monzón y Alcañiz en el año de 1427 [=1436 según Ibánez de Aoiz y Savall y Penén] por la Serenísma Señora Reina Doña María y el Rey don Juan, lugartheniente del Rey Don Alonso, se ordenó por acto de Corte la execuzión del Archibo General a la Diputazión de este Reino para custodiar los Registros de las Cortes del Reino y los demás papeles y libros conzernientes que estarán creados y los que se fuesen creando, como también los que se pudieren haver de tiempo anterior con prezisión que de dicho Archibo debían tener las llaves los Diputados del Reino. Esta disposición [pareze] tubo su Cumplimiento habiéndose establecido el dicho Archibo General de la Diputación en el Centro de la Casa llamada de la Diputazión en que está la Real Audienzia al pie de la suntuosa sala de San Jorxe y sus Papeles se hallan muy custodiados y zerrados en unos cajones primorosamente adornados; en él se allan todos los Registros de Cortes celebradas por los Serenísimos Señores Reies en este Reino, los quatro estamentos y Brazos de Cavalleros Nobles, Higos Dalgo, Prevendados y Unibersidades, los registros de actos Comunes de todo lo que deliberaban los Diputados del Reino, las firmas y Despachos de sus Regalías, los Cabreos de los Cargos y Zensales que tiene y tenía contra sí [el Reino] y los [Cabreos] de las Tenas dineros y demás Regalías que perzibía y tenía el Reino, los libros de quentas de las Rentas que produzían los drechos y propios del Reino quando los administraba éste, y los que daba quando estaba por arriendo los actos de Zensales que cargaba el Reino sobre sí, y los de las Canzelaziones y Luiziones que avía de ellos, y [los de] las Ápocas que otorgaban los acrehedores zensalistas de pensiones y cargos ordinarios; los Procesos de las Pruebas que hazían las personas inseculadas en los ofizios y demás empleos del Reino; los papeles de los servizios echos por el Reino a los Señores Reies de Aragón, los papeles originales e impresos de Historias de los Coronistas del Reino, que 
escribieron las Alegaziones en drecho en los Pleytos que siguió [el Reino] y los Prozesos que fulminaba [éste] de varios drechos y assumptos, y otros muchos papeles con sus Cartas de los Señores Reies al Reino Pribilegios de Nobles y Infanzones, hasta el año de 1707 que con motibo de la aboluzión de los fueros de este Reino de Aragón, se extinguió la Diputazión de él incorporándose todas sus Rentas y efectos al Real Patrimonio. ${ }^{601}$

601 Vid. "Alhajas que tenía la Diputación en el momento de su extinción 1707», A.D.P.Z., leg. 755-5. Citado por Ana Ximénez de Embún González (1995). 


\section{Zaragoza, 1771}

Informe sobre el antiguo archivo del reino emanado desde el Real Acuerdo de Aragón.

A.H.P.Z., Real Acuerdo, caja 18, leg. 2/5

Hay otro archivo llamado del Reyno, que también está a cargo del mismo don Pedro Lezaun, oficial mayor de la contaduría; existen todos los actos de corte que se celebraron en este Reyno en los siglos pasados, en donde hay papeles de la mayor importancia a la Corona y a los vasallos de Vuestra Majestad en este Reyno, pues para justificar las familias sus respectivas noblezas y antigüedades, se valen de dichos papeles mediante certificaciones por los actos positibos y específicos que en aquellas se encuentran de haber asistido sus antepasados a las cortes y este archivo no está dotado. 
Zaragoza, 1776

Descripción del archivo del reino de Aragón realizada por Francisco Carrasco, insertada al final de su obra sobre los procesos forales aragoneses.

Zaragoza, Biblioteca de las Cortes de Aragón, ms. L.52.

En este archivo están los libros de ynsaculaciones con otros mui puntuales de todos los que han tenido empleos hasta que duraron los fueros; éstos hacen fee de nobleza, ynfanzonías y otras cosas de mucho timbre y honor a las familias antiguas de Aragón. Este archivo está también a cargo de don Pedro Lezaun, oficial primero de la contaduría general de exército de Aragón.

En este archivo se hallará un libro magistral, papel de marquilla, que contiene nota de todos los privilegios reales y donaciones de los reyes de Aragón a los señores, villas y lugares y por las calendatas de estos libros se hallarán los papeles en dicho archivo real de Barcelona; en él hai otro libro igual pero el de Aragón que antes paraba en manos de Don Jorge de Sola Piloa, escribano de cámara, aora para en don Josef Sebastián, secretario de Acuerdo por estar en el Archivo de Registros de que aora es archivero. 


\section{[Tercer cuarto del siglo XVIII]}

Extracto de las Apuntaciones Históricas de Lezaun, en el que se indica el envio de documentación desde el archivo del reino en Zaragoza a las Cortes de Monzón presididas por Felipe II en abril de 1585.

B.N.E., ms. 9823 , f. $88 \mathrm{v}$.

Los Diputados que estavan en Monzón a 14 de abril [de 1585] les pidieron los regentes [= registros] de Actos Comunes que tratavan sobre las cosas de la Ynquisición y los motus propios que pedían con instancia los Brazos para arreglar los Memoriales que se havían de dar al Rey y la Corte General, embiando a este fin a Miguel López, archivero y escrivano principal de la Diputación. A 20 respondieron con propio a toda [f. 89r] diligencia que havían mandado a Miguel López que reconociese los registros que fuesen necesarios mientras que, habiéndoseles representado muchos inconvenientes que se podían seguir a llevarlos, pues se podía remediar llevando copias de lo que importara y no obstante que ellos ya lo havrían considerado, los consultavan antes de entregarlos para que lo representasen a los Brazos y estos resolviesen lo que gustaren, para estar a cuvierto de cualquier cosa que sucediese. Al día siguiente respondieron a Monzón que se havía determinado en la consulta que havían tenido los 4 brazos que conbenía se embiasen los registros que había pedido embiando el acto de la deliberación para su seguridad [tesorero?] por Juan Phelipe Torrellas, notario y escrivano principal de las Cortes Generales de Aragón, hecho en el claustro de la Yglesia donde estavan juntos y que quando llegasen se entregasen a las 24 personas nombradas para arreglar los memoriales de agravios generales, y que para seguridad de su conducción se valiese López de la gente de la guardia del Reyno que hubiere menester; en virtud de esta carta, se entregaron 28 registros y la copia del Proceso contra Antonio Sánchez Gamín, hecho en la Corte del Justicia de Aragón sobre la manifestación de su persona de poder del Alguacil del Santo Oficio de la Ynquisición de Valencia) hecha en Teruel, y hecha una arquimesa a propósito con dos estantes dentro y su buena cerradura. [...] Se entregaron a Miguel López, haciéndole jurar en poder del Abad de haverse bien 
y lealmente en la custodia y guardia de dichos registros y que no los perdería de vista, siempre y quando fuesen menester reconocerlos y mirarlos así los 4 Brazos, 24 personas nombradas y otras cualesquiere personas y particulares; y que el Reconocimiento que se huviese de hacer fuese en su presencia y quando no fuese menester o se le mandase, los volvería a la diputación, dándole la Instrucción de lo que havía de hacer y con orden de que tomase toda la gente de la guarda del Reyno que le pareciese para la maior seguridad en la conducción de dichos registros, todo lo qual se hizo a 24 del mismo agosto. 


\section{Zaragoza, 19 de diciembre de 1772}

Copia de la real orden por la que se regula la expedición de certificaciones por parte de los archiveros.

\section{A.D.P.Z., leg. $755-17$.}

El rey ha entendido que en algunos de los archivos de estos Reynos, se dan por los archiveros certificaciones de partidas y documentos de que se pretende formar después crédito o acción contra la Real Hacienda, sin haver intervenido a la saca las contadurías principales del exército. Para remediar este abuso, se ha servido Su Majestad mandar que, a efecto de que en lo venidero se pueda contemplar válida toda certificación o copia de que por qualquiera motivo pueda resultar alguna acción o derecho contra la Real Hacienda, Patrimonio Real o Regalía, haya de ser intervenida precisamente por el contador principal del exército. Que antes de la extracción y formación de qualesquiera de estas certificaciones y documentos, deba pasar el contador personalmente y sin fiar esta diligencia de otro alguno al Archivo con el archivero, y reconocer los libros de que se hayan de tomar las noticias que se pidan y hubieren de dar. Que en las certificaciones se diga la calidad y circunstancia de los mismos libros; esto es, que se expresen los folios, cómo empiezan y concluyen y si han sido mandados formar en su origen por decreto y orden real; expresando los fechos nombres de los ministros que las firmaron, y no teniendo esta autoridad, se advierta también diciendo quién los firmó y para qué fines, si acaso constare y si no, se expresará que no consta.

Que se exprese también en las certificaciones si hubiesse borrador, enmendados u hojas quitadas o algunas que puedan inducir sospecha de haver sido introducidas maliciosamente. Que se exprese con toda claridad si las partidas o noticias que comprehendan las certificaciones tienen algunas glosas marginales o prevenciones puestas al pie o a la cabeza de donde se extrahen; expresando igualmente si hubiere alguna nota o prevención en el resto del libro de que pueda resultar más fuerza o debilidad a lo que se certifique; y finalmente que se prevenga en las mismas certificaciones que de ellas no puede resultar efecto alguno favorable a las partes intere- 
sadas que las han solicitado, no haciéndose constar que han sido aprobadas por Su Majestad los derechos que pretendan pertenecerles en virtud de dichas certificaciones. Que a continuación de ellas deberá poner el contador principal lo siguiente: "Con mi intervención y asistencia personal, se extraxeron y comprovaron las noticias que se contienen en esta certificación, de que certifico». Con su firma entera y la fecha, y el intendente del exército deberá poner: "visto bueno» y su media firma; precediendo a estos requisitos, la del archivero y en virtud de ellas, quedarán el intendente, el contador y el archivero igualmente responsables a qualquiera ilegitimidad $\mathrm{u}$ omisión que hubiere en las certificaciones que se diesen.

En todo lo demás perteneciente a partes, deberá seguir y observarse el método que hasta aquí se ha practicado y está prescrito, para que el archivero con decretos del intendente, sin intervención de otro alguno, dé las certificaciones y demás instrumentos que soliciten los interesados; y que lo mismo se ejecute en todos los casos en que el Ministerio pida del archivero noticias para su govierno. Todo lo qual quiere Su Majestad se observe, y cumpla por Vuestra Señoría, por el contador Principal de esse exército y el archivero de la Diputación de esse Reyno y para ello manda se pongan copias fee hacientes de esta Real Orden en los libros de la contaduría principal en el archivo y en los de la secretaría de essa intendencia. Prevéngolo a Vuestra Señoría de dicha Real Orden para su cumplimiento. Dios guarde a Vuestra Señoría muchos años.

Aranjuez, seis de mayo de mil setecientos sesenta y nueve. Don Miguel de Muzquiz, señor vizconde de Valloria. Es copia de la Real Orden que original para en esta contaduría principal de exército y reyno de Aragón de mi cargo, de que certifico. Zaragoza, diez y nueve de diziembre de mil setecientos setenta y dos. 


\section{Zaragoza, enero de 1788}

Memorial del archivero Felipe Fernández de Arias sobre la situación del archivo del reino de Aragón y su evolución histórica.

A.D.P.Z., leg. 755-11. Publica Diego Navarro (1997), pp. 195-198.

En la ciudad de Zaragoza a [en blanco] de enero de 1788, el Señor Don Diego Navarro, contador principal de este exercito y Reyno de Aragón, en conseqüencia del Decreto que precede del Señor don Antonio Ximénez Navarro, intendente general del mismo exército y Reyno, passó con mí, el escrivano Principal de Rentas Reales [y de la referida intendencia] a las casas de la Real Audiencia de este Reyno en que están colocados los archivos generales de la Antigua Diputación, Baylía y Maestre Racional / a efecto de poner en posesión a don Felipe Fernández de Arias con la más posible normalidad se reconoció / y constituidos en el primero, [se] y practicó lo siguiente:

\section{Archivo de la Diputación del Reyno}

Este archivo está a los pies de la Magnífica Sala de San Jorge: su puerta es de bronce con dos llaves y entrados en él, se reconoció ser una sala / bastante $\backslash$ grande / y regna $\backslash$ embovedada, con cornisa, pintura, filetes y adornos de talla dorados y dos escudos de Armas de Aragón y primitivas de Sobrarve: Ay una bidriera con rez de ilo de yerro y reja grande alta que toma luz de la parte de la ciudad y otra reja grande / abalconada \ al piso con vista al río con bidriera /del todo inútil $\backslash$. Esta sala de archivo forma tres frentes: en el uno ay 24 cajones / bien afianzados a la parezl unidos, de madera, rotulados y 6 sin rotular; en el otro, 27 cajones rotulados o numerados y 8 sin rotular y en el otro, 29 rotulados o numerados y $16 \sin$ rotular [ni numerar], que al todo componen 110 cajones [unidos] de los quales los 88 numerados [y] /o $\backslash$ rotulados están pintados y con filetes dorados y los 22 restantes sin filetes y algunos maltratados. En el mismo archivo y sala existe una mesa o tablero grande de nogal / que forma cajón con dos medias puertas de la misma madera / y encima de ella ay un libro 
grande de papel de marca mayor cuyas cubiertas / serán de badana con cantones, / están sueltas e inutilizadas y tiene por título Yndice universal de todas las escripturas auténticas y manuscritas del Archivo del Reyno de Aragón. En el mismo libro ay una tabla / por abecedario / de las cosas más notables que contiene [por abecedario] y después sigue expresando por cajones los dichos procesos, escripturas, ordinaciones, cabreos, registros de Cortes, de Actos Comunes de la Diputación, Matrículas, Bulas, Privilegios, Cartas y otros diferentes papeles que se expresan y contiene el mismo ýndice, que aunque parece / devia contener / [contiene] 435 ojas, se reconoció estar mal foliado, sin orden ni seguridad, porque pospone y antepone / numerosos de los / los folios con mucha variedad y trastorno y ay algunas ojas sueltas y maltratadas. En el mismo ýndice y asientos / comprehende / que / [refiere] / [contiene] de los papeles que deben existir en cada cajón de los que numera, ay notas previniendo que faltan o que no están en el archivo, varios libros registros o papeles / importantes y aun de varios indica el paradero /; y haviendo también reconocido [algunos] / diferentes / de los citados cajones, especialmente / más de los \los que están sin rotular o sin numerar / se / [no se hallan] / vacíos y en / papeles [algunos en ellos] y este es el único ýndice o lucero que / ha servido y / sirve de gobierno para el expresado archivo de la Antigua Diputación del Reyno.

\section{Libros entregados por el archivero jubilado Lezaun}

Sobre la referida mesa, se hallaron 6 tomos en $4 .^{\circ}$, manuscritos intitulados Nobiliario de Aragón, trabajados por don Thomas Fermín de Lezaun para govierno de dicho Archivo, de que hizo entrega su padre, Don Pedro de Lezaun, archivero jubilado. Estos quatro tomos / parece / comprehenden las personas de los quatro Brazos del Reyno que concurrieron a las Cortes celebradas en este Reyno de Aragón desde el año de 1247 hasta las últimas de 1702 . Otros dos tomos también manuscritos y travajados por dicho don Thomas de Lezaun, que comprehenden los sugetos que se insecularon en los oficios del Reyno. Otro tomo assí mismo en 4. ${ }^{\circ}$ de las personas que se hallan en los registros de Cortes y Actos Comunes de la Diputación y obtuvieron los empleos onoríficos de ella. Otro ídem de / algunos escudos de / [algunas] armas y [blasones] / razón de familias a que corresponden / [de las algunas familias] otro ídem, que contiene los Nobles, Cavalleros, Infanzones que se hallan en diferentes vecin- 
darios desde el año de 1715 con expresión de los lugares de donde son y partido a que corresponden, para la exempción del Pago del Real Derecho del Maravedí. ${ }^{602}$ Otro ýdem delos Pueblos de la Vereda llamada de Tarazona, Borja y Teruel. Otro ýdem de la vereda de las Comunidades de Calatayud, Daroca y Teruel. Otro ydem de la vereda de la Montaña, oya de Huesca y Barbastro. Dos tomos también manuscritos en folio que assi mismo se titulan Nobiliarios que son $1 .^{\mathrm{a}}$ y $2 .^{\mathrm{a}}$ parte y comprehenden la ynseculación de varios infanzones para empleos onoríficos y descendencias de diferentes familias que obtuvieron empleos desde el año de 1626 hasta la extinción de la Diputación.

Un libro que parece haverse recogido como perteneciente este archivo en el año de 1755 de poder de un eclesiástico: su título según un cartoncillo con que está liado es Ceremonial del Reyno y oficios de él; no tiene principio, está por abecedario y le faltan las letras A B C. / Un legajo con [?] según su carpeta / otro libro de censos luydos de Rivagorza y otras noticias de los pertenecientes a Lerma y Aranda. Otro ýdem según también carpeta de varias noticias y comisiones. Otro ýdem que expresa la carpeta ser certificaciones dadas por el archivero don Pedro de Lezaun.

Un banco de respaldo viejo y maltratado y quatro taburetes de mediano servicio y no siendo posible hacer otra inspección de los papeles y libros que contiene dicho archivo, que se observan mal tratados por el uso y transcurso del tiempo, se ha hecho entrega de todo en la sobredicha forma al referido don Phelipe Fernández de Arias, nombrado archivero propietario / [con la mitad del] / en Real Orden de 2 de noviembre del año próximo pasado, que hace covera de este expediente y se dio por entregado y de las llaves que tomó a su mano, y varios / abriendo y cerrando las puertas del mismo archivo / de dichos libros, en señal de posesión.

602 Vid. Memorial del Real Derecho del Maravedí, s. XVIII, A.D.P.Z., leg. 755-7. 
Zaragoza, 24 de mayo de 1792

Relación de la visita efectuada por el padre don Joaquín Traggia al archivo de la antigua Diputación del reino, siendo su archivero don Felipe Fernández de Arias.

R.A.H., ms. 9/5219, Colección Traggia, f. 284 r.

Archivo del Reino de Aragón o del magistrado de la antigua Diputación

Este archivo, distinto del de la bailía i del antiguo Justicia de Aragón, está situado a los pies de la sala de San Jorge, por donde se entra i es una fábrica mui buena, que recibe luz por el testero que cae al Ebro. Los tres lienzos de pared fuera del que cae al río, tienen mui buenos armarios de nogal, pintados por fuera i con sus rótulos i una especie de cornisa dorada. Las puertecillas que tenían llave en lo antiguo, tienen los rótulos de su contenido. Sobre la puerta de la sala hai un retrato de Gerónimo Zurita, pintado en la pared de medio cuerpo i la bóbeda está pintada también i en la cornisa se ven los nombres de los diputados que hicieron la fábrica.

Este archivo está a cargo de don Felipe Fernández de Arias, como el de la Bailía i habiéndomelo franqueado como el otro empecé a visitarlo el día 24 de mayo de 1792. Mas como este archivo está indotado i no tiene renta alguna ni para su conservación material i dicho don Felipe tiene que asistir a su oficina, me proporcionó a don [...] Sánchez para que me asistiera las mañanas que no tubiera precisión de estar en el peso. Hai un índice mui exacto de lo contenido en cada armario i ligamen, pero faltan muchos papeles que sin duda se han robado.

Noticias que aparecen en los libros del archivo de la antigua Diputación del Reino de Aragón que en virtud de real orden está a cargo de don Phelipe Fernández de Arias [...]

Se empezó este reconocimiento día 24 de mayo de 1792. 
FUENTES Y BIBLIOGRAFÍA 



\section{FUENTES MANUSCRITAS CONSULTADAS}

\section{Archivo de la Diputación Provincial de Zaragoza}

Registros de actos comunes

$1470,1471,1472,1473,1474,1475,1483,1484,1486,1490,1492,1496$, $1497,1498,1510,1513,1516,1517,1518,1522,1525,1526,1529,1530$, $1532,1535,1537,1538,1539,1540,1541,1542,1544,1545,1547,1549$, $1550,1552,1554,1556,1557,1559,1560,1561,1562,1563,1564,1566$, $1567,1568,1569,1572,1575,1579,1581,1582,1584,1585,1587,1588$, $1589,1590,1591,1592,1595,1599,1600,1602,1603,1606,1607,1608$, $1609,1612,1614,1617,1619,1620,1621,1625,1630,1633,1636,1639$, $1640,1642,1644,1651,1653,1654,1659,1660,1663,1664,1666,1669$, $1672,1677,1680,1686,1689,1693,1701,1702,1703$.

Registros de ápocas de censales, salarios, comisiones y consultas ${ }^{603}$

$1525,1530,1534,1545,1549,1554,1559,1565,1567,1577,1586,1593$, $1598,1601,1602,1606,1609,1610,1611,1615,1620,1646,1650,1654$, $1665,1670,1675,1699,1703,1704$.

Inventarios, indices y memoriales del archivo del reino

Ms. 5: Registro de documentos existentes en el archivo de la Diputación del Reino de Aragón. 1300-1600.

603 Hasta 1602, las ápocas de censales y las ápocas de salarios se encontraban unidas. A partir de esta fecha hay una clara división administrativa entre los pagos efectuados por la Diputación en concepto de salarios y los pagos por intereses de la deuda del reino a particulares e instituciones. 
Ms. 59: Registro de documentos existentes en el archivo de la Diputación del Reino de Aragón. Documentación de los siglos XV a XVII.

Leg. 582-13: Inventario de revendiciones de censos de los siglos XV y XVI existentes en el archivo de la antigua Diputación del Reino. ${ }^{604}$

Leg. 582-14: Inventario de sentencias de censales de los años 1400 a 1470.

Leg. 582-15: Inventario de procesos de súplicas del siglo XVI.

Leg. 654-1: Rúbrica de los registros, libros y papeles que hay en el archivo del Reino de Aragón, empezada en 1660.

Leg. 681-3: Inventario de escrituras de censales.

Leg. 681-4: Inventario de luiciones de censales 1300-1586.

Leg. 681-5: Inventario de vendiciones y sentencias de censales.

Leg. 750-28, 29 y 30: Rúbrica de sindicados, privilegios, etc., que habia en el Archivo Histórico de la Diputación del Reino, siglo XVII.

Leg. 752-10: Rúbricas o inventarios de procesos existentes en el archivo del reino. S. XVII.

Leg. 754-14: Indice de documentos del archivo del Reino. Siglos XV-XVII.

Ms. 290: Indice de los registros de actos comunes 1475 a 1601.

Ms. 622: Indice sumario de los registros de actos comunes desde 1600 hasta 1700.

Registro de entrada y salida de escrituras

Ms. 338: Ingreso y salida de documentos del archivo de la Diputación del Reino. 1615-1710.

Certificaciones expedidas por el archivero

Leg. 626-33: Certificación del archivero sobre secuestro de bienes del conde de Sástago (1773).

Leg. 755-13: Noticias sobre la fe de las certificaciones de los archivos de la Diputación y Bailía y fueros y actos de cortes que los establecen y que no puedan ser inventariados, ni manifestados ni sacados.

Leg. 755-16: Certificaciones del archivero de la antigua Diputación. S. XVIII.

Otros documentos

Ms. 270: Inventario de todos los objetos ubicados en el palacio de la Diputación del Reino (finales del siglo XVI-comienzos del XVII).

604 La descripción de este inventario aparece en las fichas de la actual Diputación Provincial de Zaragoza como inventario de «renunciaciones» de censales, sin duda error de transcripción al entender la abreviatura Revenon. (revendición) por renunciación. 
Leg. 755: Caja con numerosa documentación referida casi en exclusiva al archivo del reino de Aragón durante el siglo XVIII.

\section{Biblioteca Nacional de Madrid}

Registros de actos comunes de la Diputación del reino de Aragón

1469 (BNE, ms. 17451). ${ }^{605}$

1510 (BNE, ms. 17454).

1483 (BNE, ms. 17452).

1513 (BNE, ms. 17454).

1486 (BNE. ms. 17453).

1579 (BNE, ms. 17455).

1676 (BNE, ms. 17456).

Extractos de informaciones contenidas en los registros de actos comunes

Ms. 9823: Tomás Fermín de Lezaun y Tornos, Apuntaciones históricas, parte primera Contiene las cosas más particulares que se hallan en los rexistros de actos comunes de los diputados del Reino de Aragón desde el año de 1469 en que empiezan dichos rexistros hasta el de 1707 en que se extinguió su consistorio. Tomo segundo: Contiene desde el año de 1558 en que murió el emperador Carlos Quinto hasta el de 1600, segundo del Reynado de su nieto el rey don Phelipe Segundo de Aragón y tercero de Castilla, llamado el Piadoso.

Ms. 9824: Tomás Fermín de Lezaun y Tornos, Apuntaciones históricas, parte primera..., Tomo tercero. Comprehende desde el año 1600, $2 .^{\circ}$ del reynado del rey don Phelipe $2 .^{\circ}$ de Aragón y $3 .^{\circ}$ de Castilla, llamado el "piadoso" hasta el de 1621, en que empezó a reynar su hijo Phelipe $3 .^{\circ}$ de Aragón y $4 .^{\circ}$ de Castillo [sic] llamado el Grande.

Ms. 9825: Tomás Fermín de Lezaun y Tornos, Apuntaciones históricas primera parte..., Tomo quinto. Comprehende desde el año de 1665, primero de la mernor hedad del Rey don Carlos 2. ${ }^{\circ}$ hasta el día 3 de junio de 1707, en que fue dicha extinción, reinando Phelipe $4 .^{\circ}$ de Aragón y $5 .^{\circ}$ de Castilla, el animoso.

605 Éste es uno de los seis registros de actos comunes que perteneció a Pascual de Gayangos. 
Memoriales y otros documentos relativos a la Diputación del reino de Aragón en mayor o menor grado

Ms. 11262-14: Pedro Jerónimo Sánchez de Lizaraso, Relación del estado del gobierno de Aragón (1603).

Ms. 9336: Extracto de las Cortes de Aragón formado de orden del Reyno, con las actas originales que paran en su archivo desde el año 1357 hasta el de 1547. Por Don Gerónimo Blancas, su coronista. Se copió del mismo original por don Manuel de Abbad y Lasierra, benedictino claustral, en Zaragoza a 12 de mayo de 1772.

Ms. 2377: Forma en que se preparó el salón de la Diputación de Zaragoza para la reunión de las Cortes del Reino de Aragón en 20 de septiembre de 1645.

Ms. 10383 y 10384: Información de los sucesos del Reyno de Aragón de los años 1590 y 1591. Parte II: Colección de varias cartas representaciones y otros papeles concernientes a lo que en la 1. a parte se demuestra, sacada del Archivo general de la antigua Diputación del Reino de Aragón por don Tomás Fermin de Lezaun.

Ms. 1894: Sumaria noticia de algunas cosas del Reino de Aragón. Autor el doctor Juan Pérez de Nueros, abogado fiscal del señor rey Felipe II [1577].

Ms. 8380: Papeles varios sobre el cronista Diego José Dormer.

Ms. 987: Lorenzo Ibáñez de Aoiz, Ceremonial i breve relación de todos los cargos y cosas ordinarias de la Diputación del Reyno de Aragón. [...] Hecho en el año $M D C X I$.

Ms. 2922: Lorenzo Ibáñez de Aoiz, Ceremonial del Illustrísimo consistorio del Reyno de Aragón, copiado y sacado en limpio el año 1663 por orden de los ilustrísimos señores diputados.

Ms. 799: Gerónimo Martel, Ceremonial de los asientos de los consistorios de los Diputados, inquisidores, contadores y Iudicantes del Reyno de Aragón. [Existe edición facsímil a cargo de Diego Navarro Bonilla, Zaragoza, Institución «Fernando el Católico», 1999.]

Ms. 2377: Sucesos del año de 1645 y 46.

Ms. 1264: Índices y borradores de la documentación existente en el archivo de la antigua Diputación del reino de Aragón, por F. José Velasco [1750].

Ms. 9995: Informe de Santiago Agustín Riol al marqués de Grimaldo sobre los papeles de la Monarquía [30 de agosto de 1726].

\section{Real Academia de la Historia}

Colección Salazar y Castro

Ms. 9/548: Papeles sobre los cronistas de Aragón. 
Ms. 9/671: Indice de los registros de actos comunes de los diputados en 1603; disposición del archivo de Aragón.

Ms. 9/672: Indice de los registros de actos comunes del Reino de Aragón.

Colección Nasarre

Ms. 11/7946: Memorial de renuncia del cronista Dormer a su oficio y contestación por los diputados del Reino. [Siglo XVIII.]

\section{Colección Traggia}

Ms. 9/5219: Información sobre los archivos del Reino y de la Bailía y Maestre Racional. [Siglo XVIII.]

\section{Archivo Municipal de Zaragoza}

Caja 7829: Informe sobre los restos arquitectónicos del palacio de la Diputación del Reino. [Siglo XIX.]

\section{Archivo Histórico Provincial de Huesca}

Familias, Casa Bardají, leg. 27-1-5: Certificación de don Manuel Antonio Terreros, responsable del archivo de la antigua Diputación del reino (1798).

\section{Archivo Histórico Provincial de Zaragoza}

Real Acuerdo, caja 18, legajo 1, 2/5, 12, 13, 18. Informes del intendente sobre los archivos ubicados en el palacio de la Real Audiencia. [Siglo XVIII.]

Libro del Real Acuerdo correspondiente a los años 1745/1746.

\section{Biblioteca Universitaria de Zaragoza}

Ms. 97: Jerónimo de Blancas, Sumario y Resumario de las Cortes celebradas en Aragón, Zaragoza, [1595].

Mss. 106-142: Faustino Casamayor Zeballos, Años políticos e históricos de las cosas particulares ocurridas en Zaragoza: 1782-1833, 37 vols. 
Ms. 199: Lorenzo Ibánez de Aoiz, Ceremonial y breve relación de todos los cargos y cosas ordinarias de la Diputación del Reino de Aragón hecho en el año de mil seyscientos $y$ once [...].

\section{Biblioteca de las Cortes de Aragón}

Tomás Fermín de Lezaun y Tornos, Apuntaciones históricas sacadas de los registros de actos comunes de los diputados del Reino de Aragón desde 1469 hasta 1707..., tomos I (1469-1558), II (1558-1600), III (1600-1621) y V (1665-1707).

Francisco Carrasco, Los cuatro procesos forales de Aragón, [1776?], ms. L.52. Incluye una interesante descripción de los archivos aragoneses de la época, con mención especial a los ubicados en el palacio de la antigua Diputación del reino.

\section{Archivo General de Simancas}

Secretaría y Superintendencia de Hacienda, leg. 539 (Inventario de José de Yoldi, 1749).

Secretaría y Superintendencia de Hacienda, leg. 543 (Expediente de obras en el archivo de la bailía y maestre racional).

\section{Archivo de la Corona de Aragón}

Manuscrito misceláneo n. ${ }^{\circ}$ 220: Receptas hechas por mi Don Joseph Fuenbuena y de Ygal, cavallero de el orden de Alcántara y veedor de las guardias de a pie y a cavallo de el Reyno de Aragón, arrendador y administrador de las generalidades del dicho Reyno de Aragón desde el día 20 de Henero de el año de 1699 asta 19 de el mismo mes de 1700.

Diversos, Patrimoniales, Sástago, lig. 4, n.o 25: Certificaciones del archivero del reino.

\section{Archivo General de la Administración (Alcalá de Henares)}

Sección Educación y Ciencia, cajas 6962-6963 olim leg. 8176. 


\section{FUENTES IMPRESAS ANTIGUAS}

Andrés de Uztarroz, Juan Francisco, y Diego José Dormer (1680), Progressos de la Historia en el Reyno de Aragón, y elogios de Gerónimo Zurita, su primer cronista..., Zaragoza, Herederos de Diego Dormer.

BlanCAS, Jerónimo de (1588), Aragonensium rerum commentarii, Zaragoza, Laurentius Robles et Didacus Fratres. [Existe ed. facs. de la ed. de Zaragoza, Diputacón Provincial, 1878, a cargo de Guillermo Redondo Veintemillas y Esteban Sarasa Sánchez, Zaragoza, Cortes de Aragón, 1995.]

- (1680), Innscripciones latinas a los retratos de los Reyes de Sobrarbe, Condes antiguos, y Reyes de Aragón, puestos en la Sala Real de la Diputación de la ciuad de Zaragoça... traducidas en vulgar... por Don Martín Carrillo, Abad de la Real Casa de Montearagón, con la descripción de la Sala, y otras noticias... por el Doctor Diego Iosef Dormer, En Zaragoça. [Existe ed. facs. a cargo de Guillermo Redondo Veintemillas y Carmen Morte García, Zaragoza, Cortes de Aragón, 1996.]

Blasco de Lanuza, Vicencio (1622), Historias eclesiásticas y seculares de Aragón, Zaragoza, Juan de Bonilla. [Existe ed. facs. a cargo de Guillermo Redondo Veintemillas, Encarna Jarque Martínez y José Antonio Salas Auséns, Zaragoza, Cortes de Aragón, 1998, 2 vols.]

Jordán DE Asso, Ignacio (1798), Historia de la Economía Política de Aragón, Zaragoza, Francisco Magallón. [Existe una edición moderna con pról. e índices de José Manuel Casas Torres y pról. de Antonio Higueras Arnal, Zaragoza, Guara, 1983.]

LeONARDO DE ARGensola, Bartolomé (1996), Alteraciones populares de Zaragoza: año 1591, ed. Gregorio Colás Latorre, Zaragoza, Institución «Fernando el Católico».

Martel, Jerónimo (1641), Forma de celebrar Cortes en Aragón escrita por... Chronista del Reyno. Dedicada a los ilustrísimos señores Diputados del Reyno, Zaragoza. [Existe ed. facs. a cargo de Guillermo Redondo Veintemillas y Esteban Sarasa Sánchez, Zaragoza, Cortes de Aragón, 1984.]

Murillo, Diego (1616), Fundación milagrosa de la capilla angélica y Apostólica de la Madre de Dios, Zaragoza, Sebastián Matenad. 


\section{BIBLIOGRAFÍA}

AbAD, J. M., D. J. Buesa y A. LAMANa (1977), «Teruel y sus reivindicaciones en las Cortes de 1427-1428», Teruel, 57-58, pp. 75-108.

Abadía Irache, A. (1993), «Las Diputaciones de la Corona de Aragón», en Señorío y crédito en Aragón en el siglo XVI, Zaragoza, Institución «Fernando el Católico", pp. 32-37.

AbIZANDA y BROTO, M. (1917), Documentos para la historia artística y literaria de Aragón (siglo XVI), Zaragoza, La Editorial, 3 vols.

Aguinagalde Olaizola, F. DE B. (1988), «Elementos para una historia de los archivos y la archivística desde una perspectiva interdisciplinar», Irargi, 1, pp. 63-110.

- (1993), «Erudición y organización de archivos privados en la monarquía absoluta: de la función común a la configuración de una profesión específica», en Francisco M. Gimeno Blay (ed.) (1993), Erudición y discurso histórico: las instituciones europeas (S. XVIII-XIX), Valencia, Universidad de Valencia, pp. 129-156.

AlCoberro, Agustí (1993), «L'arxiu real de Barcelona i la Historiografía humanista: Les Cróniques d'Espanya de Pere Miquel Carbonell», Pedralbes, vol. 13, n. ${ }^{\circ}$ 2, pp. 515-524.

Algarra Pardo, Víctor M. (1996), «Espacios de poder: pavimentos cerámicos y escritura en el Real de Valencia en época de Alfonso el Magnánimo», en $X V$ Congreso de Historia de la Corona de Aragón: El poder real en la Corona de Aragón (siglos XIV-XVI), Zaragoza, Diputación General de Aragón, tomo 1, vol. 3, pp. 269-290.

AlmiÑAnA, G., y Carlos López RodríGuez (1997), «Una propuesta de difusión de la información para el Arxiu del Regne de Valencia: edición en microficha o CD-ROM de índices, inventarios y catálogos», en II Jornadas sobre cultura en la Comunitat Valenciana. Biblioteques, arxius i centres de documentació, vol. 2, pp. 461-464. 
Alvar EzQuerra, Alfredo (1992), «Enrique Cock: un humanista holandés en la España de Felipe II», Hispania, vol. LII, n. ${ }^{\circ} 2$, pp. 521-557.

- (1999), "Aspectos de la vida diaria en la corte del rey de España», en José Alcalá-Zamora y Queipo de Llano (dir.) (1999), La vida cotidiana en la España de Velázquez, Madrid, Temas de Hoy, pp. 91-108.

- (2000a), «La historia, los historiadores y el Rey en la España del Humanismo», en Alfredo Alvar Ezquerra (coord.) (2000), Imágenes históricas de Felipe II, Madrid, Centro de Estudios Cervantinos, pp. 217-254.

- (2000b), «La necesidad de modernización historiográfica y los cronistas de Carlos V», en Bernardo J. García García (dir.) (2000), El imperio de Carlos $V$ : procesos de agregación y conflictos, Madrid, Fundación Carlos de Amberes, pp. 301-324.

ÁlvareZ-Coca GonZÁlez, María Jesús (1987), «La figura del escribano», Boletín de la Anabad, vol. XXXVII, n. ${ }^{\circ}$ 4, pp. 555-564.

Álvarez Gracia, A., y J. F. Casabona Sebastián (1989), «La casa de la Diputación del Reino", en A. Álvarez Gracia et al., La Plaza de la Seo: Investigaciones histórico arqueológicas, Zaragoza, Ayuntamiento de Zaragoza (Sección de Arqueología), pp. 61-75.

ARCO Y GARAY, R. del (1918), «La Historia eclesiástica de la ciudad de Zaragoza», Boletin de la Real Academia de la Historia, vol. 72, n. ${ }^{\circ}$ VI, p. 505.

- (1934), La erudición aragonesa en el siglo XVII: En torno a Lastanosa, Madrid, Cuerpo Facultativo de Archiveros, Bibliotecarios y Arqueólogos.

- (1942), Repertorio de manuscritos referentes a la historia de Aragón, Madrid, Instituto Jerónimo Zurita (Consejo Superior de Investigaciones Científicas).

- (1954), "Cortes aragonesas de los Reyes Católicos», Revista de Archivos, Bibliotecas y Museos, 5. é época, vol. 60, $\mathrm{n}^{\circ}$ 1, pp. 77-103.

Armillas, J. A. (2000), La Diputación del Reino de Aragón, Zaragoza, Caja de Ahorros de la Inmaculada.

— y E. Solano (1992), «La Diputación de Aragón: entre el rey y el reino», Ivs Fvgit, 1, pp. 11-35.

Arregui, F. (1952), En torno a la vista de Zaragoza de Velázquez-Mazo, Huesca. ARribas ARRANZ, Filemón (1959), «Le plus ancien règlement des Archives de Simancas», en Mélanges offerts par ses confrères à Charles Braibant, Bruselas, Comité des Mélanges Braibant, pp. 9-15.

Arrieta Alberdi, Jon (1994), El Consejo Supremo de la Corona de Aragón (14941707), Zaragoza, Institución «Fernando el Católico».

BAena del AlCÁZAR, Mariano (1990), Curso de ciencia de la administración, Madrid, Tecnos, 2.a ed. 
BAUTIER, R. H. (1968), «La phase cruciale de l'histoire des archives: la constitution des dépôts et la naisance de l'archivistique (XVIème-XIXème siècle)", Archivum, XVIIII.

Bayod Pallarés, Roberto G. (1979), El gobierno de Aragón durante el "gobierno intruso" de los Napoleón, Zaragoza, Librería General.

Belenguer Cebrí́, Ernest (1996), «La Monarquía Hispánica vista desde la Corona de Aragón», en Felipe Ruiz Martín (dir.) (1996), La proyección europea de la Monarquía Hispánica, Madrid, Editorial Complutense, pp. 107-132.

Bermejo CABrero, José Luis (1980), "Orígenes del oficio de cronista real», Hispania, vol. XL, n. ${ }^{\circ} 145$, pp. 395-414.

- (1997), «De la Diputación de las Cortes de Castilla a la Diputación General de Cortes», en Josep Serrano Daura (coord.) (1997), El territori i les seves institucions històriques (Actes de les Jornades d'estudi conmemoratives del 650è aniversari de la incorporació definitiva del marge dret del riu Ebre a Catalunya-Ascó, 28-30 de novembre de 1997-), Barcelona, Fundació Noguera, vol. 1, pp. 463-498.

BlanCo Lalinde, L. (1996), La actuación parlamentaria de Aragón en el siglo XVI: Estructura y funcionamiento de las Cortes Aragonesas, Zaragoza, Cortes de Aragón.

Blasco Ijazo, José (1988), "El Palacio de la Diputación Provincial», en Aquí Zaragoza, Zaragoza, Caja de Ahorros de Zaragoza, Aragón y Rioja, vol. 6, pp. 59-65.

Bonet Navarro, Á. (1982), Procesos ante el Justicia de Aragón, Zaragoza, Guara.

- E. Sarasa Sánchez y G. Redondo Veintemillas (1985), El Justicia de Aragón: historia y derecho (breve estudio introductorio), Zaragoza, Cortes de Aragón.

Borau de Latrás, Miguel (1806), Guía Instructiva de la ciudad de Zaragoza para litigantes y pretendientes..., Zaragoza, Imp. de Miedes.

Born, Lester K. (1955), «The De Archivis commentarius of the Alberto Barisoni», Archivalische Zeitschrift, 50-51, pp. 12-22.

Borrás Gualis, G. M. (1972), Datos para la historia de Zaragoza durante la Guerra de Sucesión, 1700-13, Zaragoza.

- (1973), La Guerra de Sucesión en Zaragoza, Zaragoza, Institución «Fernando el Católico».

- (1995), «El palacio de los Reyes Católicos en la Aljafería de Zaragoza», en Esteban Sarasa (pres.), Fernando II de Aragón: el Rey Católico, Zaragoza, Institución «Fernando el Católico», pp. 363-378.

Bosqued Fajardo, J. R. (1986), La Cartuja de Aula Dei de Zaragoza (Ventanas en el cielo), Zaragoza, Caja de Ahorros de la Inmaculada. 
Bouza Álvarez, Fernando (1992), Del escribano a la biblioteca: la civilización escrita europea en la alta edad moderna (siglos XV-XVII), Madrid, Síntesis.

- (1998), Imagen y propaganda: capitulos de historia cultural del reinado de Felipe II, Madrid, Akal.

- (1999a), «Escritura, propaganda y despacho de gobierno», en Antonio Castillo (ed.) (1999), Escribiry leer en el siglo de Cervantes, Barcelona, Gedisa, pp. 85-110.

- (1999b), «Aulas, bibliotecas y archivos como consumación de la memoria humana», en Comunicación, conocimiento y memoria en la España de los siglos XVI y XVII, Salamanca, Seminario de Estudios Medievales y Renacentistas, pp. 107-129.

- (2001), «De memoria, archivos y lucha política en la España de los Austrias», en Corre manuscrito: una historia cultural del Siglo de Oro, Madrid, Marcial Pons, pp. 241-283.

BOYA SAURA, L. (1952), ¿Una pintura zaragozana del siglo XVII?, Zaragoza.

BRAUDEL, Fernand (1987), El Mediterráneo y el mundo mediterráneo en la época de Felipe II, México, Fondo de Cultura Económica, 2 vols.

BRENNEKE, Adolf (1968), Archivistica: contributo alla teoria ed alla storia archivistica europea, trad. Renato Perella, Milán, Antonino Giuffré.

Buesa, D., y G. Redondo Veintemillas (1979), «Los archivos aragoneses», en 1. as Jornadas de Estudios sobre Aragón: Teruel, 18-20 diciembre de 1978, Zaragoza, Imp. Cometa, pp. 21-39.

Burón CASTRO, Taurino (1993), "Archivología: una mirada hacia atrás...», Boletín de la Anabad, vol. XLIII, n. ${ }^{\circ}$ 1, pp. 7-30.

- (1994), «AArchiveros o archivistas?», Boletín de la Anabad, vol. XLIV, n.o 3, pp. 21-27.

CAmarena, J. (1955), «Función económica del "General del regne de Valencia”", Anuario de Historia del Derecho Español, XXV, pp. 528-542.

Canellas López, Á. (1933), «El testamento de Jerónimo Zurita y otros documentos a él relativos», Cuadernos de Historia Jerónimo Zurita, 1, pp. 301-320.

- (1950), «Antecedentes históricos de las armas heráldicas de la Diputación de Aragón", Estudios de Edad Media de la Corona de Aragón, vol. IV, pp. 447-450.

- (1955-1956), "Panorama de la historia interna de Aragón en los años 14101458», Cuadernos de Historia Jerónimo Zurita, 8-9, pp. 7-39.

- (1959), "Datos para la historia de los Reinos Peninsulares en el primer tercio del siglo XVI: 18 nuevos documentos de la alacena de Zurita», Boletín de la Real Academia de la Historia, CXLV, pp. 231 y ss.

- (1968), «Fuentes documentales para la historia de Aragón: nuevos fondos adquiridos por la Diputación Provincial de Zaragoza», Boletín de la Real Academia de la Historia, CLXII, pp. 51-62. 
Canellas López, Á. (1969), Fuentes de Zurita: documentos de la alacena del cronista relativos a los años 1508-1511, Zaragoza, Institución «Fernando el Católico».

- (1971), Fuentes de Zurita: documentos de la alacena del cronista relativos a los años 1302-1478, Zaragoza, Institución "Fernando el Católico».

- (1979), Instituciones aragonesas de antaño: la Diputación del Reino, Zaragoza, Institución «Fernando el Católico».

- (1981), "Archivo de la Diputación Provincial de Zaragoza», en Estado actual de los archivos con fondos aragoneses: Primeras Jornadas de Archivos, Madrid, Ministerio de Cultura, pp. 93-99.

- (1982), Documentación Napolitana en Zaragoza relativa a la devolución de tierras confiscadas a napolitanos angevinos pactada en el tratado de Blois (20-X1505), Zaragoza, Institución "Fernando el Católico».

- (1983), Doce documentos fiscales aragoneses del siglo XIII de la alacena de Zurita, Zaragoza, Institución «Fernando el Católico».

- (1984), «Por un archivo histórico facticio de Aragón», Cuadernos de Historia Jerónimo Zurita, vol. 49-50, pp. 195-198.

CaÑada SaURAS, J. (1978a), «Índice de los fondos genealógicos nobiliarios del Archivo de la Diputación de Zaragoza», Hidalguía, vol. XXVI, n. ${ }^{\circ}$ 147, pp. 353-376.

- (1978b), «Índice de los procesos de infanzonía conservados en el Archivo Histórico de la Real Audiencia de Aragón", en Estudios genealógicos, heráldicos y nobiliarios en honor de Vicente de Cadenas Vicent con motivo del XXV de la revista Hidalguía, Madrid, Hidalguía, pp. 213-271.

- (1981), «El archivo de la Audiencia Territorial de Zaragoza», en Estado actual de los archivos con fondos aragoneses: Primeras Jornadas de Archivos, Madrid, Ministerio de Cultura, pp. 123-127.

- (1986), «La documentación judicial en Zaragoza», en Guillermo Pérez Sarrión (ed.) (1986), El Patrimonio Documental Aragonés y la Historia, Zaragoza, Diputación General de Aragón, pp. 437-447.

CAPDEFERro i PlÁ, Josep (1997), "Una aproximació a l'activitat dels assessors ordinaris de la Diputació del General de Catalunya al segle XVII», en Josep Serrano Daura (coord.) (1997), El territori $i$ les seves institucions històriques (Actes de les Jornades d'estudi conmemoratives del 650è aniversari de la incorporació definitiva del marge dret del riu Ebre a Catalunya -Ascó, 28-30 de novembre de 1997-), Barcelona, Fundació Noguera, vol. 2, pp. 687-702.

Casaus Ballester, María José (1997), Archivo ducal de Hijar: catálogo de los fondos del antguo ducado de Hijar (1268-1919), Zaragoza, Diputación General de Aragón (Departamento de Educación y Cultura) / Instituto de Estudios Turolenses. 
CASTÁN y Alegre, Miguel Ángel (1998), «La baja nobleza aragonesa (16001738) en un manuscrito del siglo XVIII: La vereda de Calatayud», Emblemata, 4, pp. 209-261.

Castellano, Juan Luis (1990), Las Cortes de Castilla y su Diputación (1621-1789): entre el pactismo y el absolutismo, Madrid, Centro de Estudios Constitucionales.

CASTILLO EspinOSA, S. (1994), «Fondos aragoneses en la Biblioteca Nacional y en la Real Academia de la Historia», Ivs Fvgit, 2, pp. 63-80.

CAstillo Genzor, A. (1955), «El archivo histórico de la Real Audiencia de Aragón», Hidalguía, 12 (septiembre-octubre), pp. 625-640.

CASTILlo GOMEZ, Antonio (1997), Escrituras y escribientes: prácticas de la cultura escrita en una ciudad del Renacimiento, Las Palmas de Gran Canaria, Gobierno de Canarias / Fundación de Enseñanza Superior a Distancia de Las Palmas de Gran Canaria.

- (1998), «La fortuna de lo escrito: funciones y espacios de la razón gráfica (siglos XV-XVII)», Bulletin Hispanique, vol. 100, n. ${ }^{\circ}$ 2, pp. 343-381.

- (1999), "Como del pan diario: de la necesidad de escribir en la Alcalá Renacentista (1446-1557)», Scrittura e civiltá, XXIII, pp. 307-378.

- (2001), «Entre public et privé: Stratégies de l'écrit dans l'Espagne du Siècle d'Or», Annales, 4-5 (julio-octubre), pp. 803-829.

- (coord.) (2002), Historia de la Cultura escrita: del próximo Oriente antiguo a la sociedad informatizada, Gijón, Trea.

Clanchy, Michael (1985), «Literacy, law, and the power of the state», en Culture et idéologie dans la genèse de l'état moderne. Actes de la table ronde organisée par le Centre National de la Recherche Scientifique et l'École Française de Rome, Rome, 15-17 octobre 1984, Roma, École Française de Rome, pp. 25-34. [Existe traducción al español: La cultura escrita, la ley y el poder del estado, Valencia, Universidad de Valencia (Departament d'Història de l'Antiguitat i de la Cultura Escrita), 1999.]

Clemente, Enriqueta (1997), Las Cortes de Aragón en el siglo XVII, Zaragoza, Cortes de Aragón.

Colás Latorre, Gregorio (1998), La Corona de Aragón en la Edad Moderna, Madrid, Arco Libros.

- y J. A. SALAS (1975), «Las cortes aragonesas de 1626: el voto del servicio y su pago", Estudios de Historia Modernal75, pp. 87-139.

- y J. A. Salas (1977), Aragón bajo los Austrias, Zaragoza, Librería General.

- y J. A. Salas (1978), «Repercusiones económicas y sociales en Zaragoza del pago de la sisa de 1626», Estudios de Historia Moderna/78, pp. 151-168.

- y J. A. SALAS (1982), Aragón en el siglo XVI: Alteraciones sociales y conflictos políticos, Zaragoza, Universidad de Zaragoza (Departamento de Historia Moderna). 
Conde y Delgado De Molina, R. (1994a), «Los archivos reales o la memoria del poder", en XV Congreso de Historia de la Corona de Aragón. Actas. Tomo I: El poder Real en la Corona de Aragón, Zaragoza, Gobierno de Aragón, pp. 121-139.

- (1994b), «Una discutible decisió arxivística del segle XV», Lligall: Revista catalana d'Arxivistica, 8, pp. 11-17.

- (1994-1995), «La creación del archivo real de Valencia», Estudis Castellonencs (Homenaje a José Trenchs Odena), vol. 6, pp. 371-381.

- (1998a), «Archivos y archiveros en la Edad Media Peninsular», en Juan José Generelo y Ángeles Moreno López (coords.) (1998), Historia de los archivos y de la archivistica en España, Valladolid, Universidad de Valladolid, pp. 13-29.

- (1998b), «La búrxula del present Arxiu Real de Barcelona, de Pere Benet (1601). Primera Guía de l'Arxiu", Lligall, vol. 13, pp. 11-37.

- (1999a), «Los archivos de la Monarquía Hispánica», en Felipe II y el Mediterráneo: La Monarquía y los Reinos (I), Madrid, Sociedad Estatal para la Conmemoración de los Centenarios de Felipe II y Carlos V, pp. 193-211.

- (1999b), La Brújula: guia del archivo Real de Barcelona, Pere Bonet (1601), Madrid, Secretaría de Estado de Cultura.

Conde Villaverde, María Luisa, y Rosana de Andrés Díaz (1996), «Destrucción de documentos en España: historia, prevención, reconstrucción», Archivum, XLII, pp. 119-129.

Cortés Alonso, Vicenta (1979), Archivos de España y América: materiales para un manual, Madrid, Universidad Complutense.

- (1983), «Las ordenanzas de Simancas y la administración castellana», en Actas del IV Symposium de Historia de la Administración, Madrid, INAP, pp. 197224.

- (1984), «La producción documental en España y América en el siglo XVI», Anuario de Estudios Americanos, XLI, pp. 195-251.

- (1986), La escritura y lo escrito: paleografía y diplomática de España y América en los siglos XVI y XVII, Madrid, Instituto de Cooperación Iberoamericana.

Cosculluela Montaner, Luis (1995), Manual de Derecho Administrativo, Madrid, Civitas.

Crespo Nogueira, Carmen (1964-1965), «Los archivos españoles y la Ilustración: el Archivo del Reino de Valencia», Revista de archivos, bibliotecas y museos, vol. LXXII, n. ${ }^{0} 1-2$, pp. 67-73.

Cruz Herranz, Luis Miguel de la (2000), «Los archivos y la archivística en España e Iberoamérica: pasado, presente y futuro", en Archivos y sistemas, Madrid, Ministerio de Educación, Cultura y Deporte, pp. 11-65.

CRuz Mundet, José Ramón (2001), Manual de Archivistica, Madrid, Fundación Germán Sánchez Ruipérez / Pirámide, 4. ${ }^{\mathrm{a}}$ ed. aum. y correg. 
Cuartas Rivero, Margarita (1991), «Los contadores-secretarios de la Diputación de las Cortes de Castilla. 1615", en Les Corts a Catalunya: actes del congrés d'història institucional (28, 29 i 30 d'abril de 1988), Barcelona, Generalitat de Catalunya, pp. 403-406.

D'ADDARIO, Arnaldo (1983-1984), «Principi e metodi dell'inventariazione archivistica fra XVII e XIX secolo», Archiva Ecclesiae, 26-27, pp. 29-48.

- (1990), "Lineamenti di storia dell'archivistica», Archivio Storico Italiano, vol. 543, n. ${ }^{\circ} 1$, pp. 3-36.

D’HAENENS, Albert (1983), «Écrire, utiliser et conserver des textes pendant 1500 ans: la relation occidental à l'écriture», Scrittura e Civiltà, 7, pp. 225-260.

Danvila y Collado, M. (1881), Las libertades de Aragón: ensayo histórico, juridico y político, Madrid, Fortanet.

Daudevard de Ferussac, J. (1908), Diario de los sitios de Zaragoza vertido al español por F.J.J., Zaragoza.

Delgado Echeverría, Jesús (1997), Los Fueros de Aragón, Zaragoza, Caja de Ahorros de la Inmaculada.

Delsalle, Paul (1998), Une histoire de l'archivistique, Quebec, Presses de l'Université du Québec.

Duchein, M. (1977), «Le respect des fonds en archivistique: principes théoriques et problemes pratiques», La Gazette des archives, 97, pp. 71-96. [Publicado en español en P. Walne (rec.) (1985), La administración moderna de archivos y la gestión de documentos: el prontuario RAMP, París, UNESCO, 1985, pp. 69-92.]

EgIDO, Aurora (1979), «Retratos de los Reyes de Aragón», Cuadernos de Historia Jerónimo Zurita, vol. 33-34, pp. 173-223.

EsCudero, José Antonio (1995), Curso de Historia del Derecho: Fuentes e Instituciones político-administrativas, Madrid, [s.n.].

- (2002), Felipe II: El rey en el despacho, Madrid, Real Academia de la Historia.

Esteban NaVARRO, Miguel Ángel (1995), «La representación y la organización del conocimiento en los archivos", en Organización del conocimiento en sistemas de información y documentación: Actas del I Encuentro de ISKO-España, Zaragoza, ISKO-España, pp. 65-90.

- (1997), «Principios, reglas y técnicas para la gestión de cuadros de clasificación de fondos de archivos", en Organización del conocimiento en sistemas de información y documentación: Actas del II Encuentro de ISKO-España, Zaragoza, Universidad de Zaragoza, pp. 107-126.

Estrada I RiUs, Albert (1999-2000), «La Deputació del General de Catalunya i el territori del Principat: notas per al seu estudi», Ivs Fvgit, 8-9, pp. 75-94.

FALCÓN PÉREZ, María Isabel (1987), Libro del reparo del General de Aragón (14891498): fogajes de 1489, 1490 y 1491, Zaragoza, Anubar. 
FALCÓN PÉREZ, María Isabel (1990), "Fogajes, monedajes y compartimientos como fuente para el estudio de la toponimia aragonesa medieval», en Metodología de la investigación cientifica sobre fuentes aragonesas, Zaragoza, Instituto de Ciencias de la Educación, vol. 5, pp. 281-290.

FARGE, Arlette (1991), La atracción del archivo, Valencia, Institució Alfons el Magnánim.

FATÁs, G., y G. M. BORRÁs GuAlis (1974), Zaragoza 1563: presentación y estudio de una vista panorámica inédita, Zaragoza, [s.n.].

Fernández Álvarez, Manuel (1989), El siglo XVI: Economía, sociedad, instituciones, Madrid, Espasa Calpe (Historia de España Menéndez Pidal, vol. XIX).

FERnÁndeZ Flórez, José Antonio (1993), «La congregación benedictina de Valladolid en el siglo XVIII», en Francisco M. Gimeno Blay (ed.) (1993), Erudición y discurso histórico, Valencia, Universidad de Valencia, pp. 101-128.

Ferrer i Maillol, María Teresa (1991), "Origen i evolució de la Diputació del General de Catalunya", en Les Corts a Catalunya: actes del congrés d'història institucional (28, 29 i 30 d'abril de 1988), Barcelona, Generalitat de Catalunya, pp. 152-159.

Ferrer Plou, B. (1995), «Informe sobre el archivo de la Diputación Provincial de Zaragoza», en 5. as Jornadas de archivos aragoneses, Zaragoza, Diputación General de Aragón, pp. 131-145.

- (2001), «Tipología documental de la Diputación del Reino de Aragón según un inventario del siglo XVI», Boletín de la ANABAD, vol. 51, n. ${ }^{\circ} 2$, pp. 47-54.

- y Alicia Sánchez Lecha (2000), Guía del Archivo de la Diputación Provincial de Zaragoza, Zaragoza, Diputación Provincial de Zaragoza.

Ferro, V. (1987), «La Diputació del General», en El Dret Públic Catalá: Les Institucions a Catalunya fins al Decret de Nova Planta, Vic/Osona, Eumo, pp. 243-288.

- (1997), «La Deputació del General de Catalunya», en Josep Serrano Daura (coord.) (1997), El territori i les seves institucions històriques (Actes de les Jornades d'estudi conmemoratives del 650è aniversari de la incorporació definitiva del marge dret del riu Ebre a Catalunya -Ascó, 28-30 de novembre de 1997-), Barcelona, Fundació Noguera, vol. 1, pp. 441-462.

FONT RIUS, Josep Maria (1949), Instituciones medievales españolas, Madrid, Consejo Superior de Investigaciones Científicas, pp. 34-35.

FUSTER RUIZ, Francisco (1996), «Los inicios de la archivística española y europea», Revista General de Información y Documentación, vol. 6, n. ${ }^{\circ}$ 1, pp. 43-77.

García CuAdrado, Amparo (1998), «La investigación en Historia de las instituciones documentales: estado de la cuestión y propuesta metodológica», Anales de Documentación, 1, pp. 55-74. 
García de Enterría, E., y T. R. Fernández (1990), Curso de Derecho Administrativo, Madrid, Civitas.

GARCía GÓMEZ, María Dolores (1998), La biblioteca regalista de un súbdito fiel: Melchor de Macanaz, Alicante, Instituto de Cultura «Juan Gil-Albert».

GARCía RuipéreZ, Mariano (1999), «La descripción de la documentación municipal en España (Siglos XIV-XVIII)", en I Jornadas de Archivos Históricos en Granada (Granada, 27 y 28 de mayo de 1999), Granada, Ayuntamiento de Granada, vol. 2: ponencias. [Se han publicado juntamente ponencias y comunicaciones en un CD-ROM.]

- y M. C. Fernández Hidalgo (1999), Los archivos municipales en España durante el Antiguo Régimen, Cuenca, Universidad de Castilla-La Mancha.

García de Valdeavellano, Luis (1986), Curso de Historia de las Instituciones españolas: de los orígenes al final de la Edad Media, Madrid, Alianza.

GASCÓN PÉREZ, Jesús (1995), Bibliografía crítica para el estudio de la rebelión aragonesa de 1591, Zaragoza, Centro de Documentación Bibliográfica Aragonesa / Institución «Fernando el Católico».

- (1997), "Defensa de los fueros y fidelidad a la Monarquía en la rebelión aragonesa de 1591», en Pablo Fernández Albadalejo (coord.) (1997), Monarquía, imperio y pueblos en la España Moderna (Actas de la IV Reunión científica de la Asociación Española de Historia Moderna), Alicante, Asociación Española de Historia Moderna / Universidad de Alicante, pp. 459-475.

GaY Molins, Pilar, (1995), Plan para la organización de fondos eclesiásticos aragoneses: el cuadro de clasificación, Zaragoza, Comisión Regional del Patrimonio Cultural de la Iglesia en Aragón, pp. 7-26.

"Generalitat», en Guía del Archivo del Reino de Valencia, Valencia, Generalitat Valenciana, 2000, pp. 39-42.

Gil Pujol, Xavier (1978), «La integración de Aragón en la monarquía hispánica del siglo XVII a través de la administración pública», Estudios del Departamento de Historia Moderna, pp 239-265.

- (1991a), «Las Cortes de Aragón en la Edad Moderna: comparación y reevaluación", en Les Corts a Catalunya: actes del congrés d'història institucional (28, 29 i 30 d'abril de 1988), Barcelona, Generalitat de Catalunya, pp. 304-317.

- (1991b), «Lupercio Leonardo de Argensola, historiador, en la historiografía de su época», en Lupercio Leonardo de Argensola (1991), Información de los sucesos del Reino de Aragón en los años de 1590 y 1591, Zaragoza, Edizions de l'Astral / El Justicia de Aragón, pp. VII-XLVIII.

- (1997), "Aragonese constitutionalism and Habsburg Rule: The Varying Meanings of Liberty", en Spain, Europe and the Atlantic World: Essays in Honour of John H. Elliott, Cambridge University Press, pp. 160-187. 
Gimeno Blay, Francisco M. (1995), Quemar libros..., qué extraño placer, Valencia, Epísteme (Eutopías. Documentos de trabajo, 104).

- (1999), «Missivas, mensageras, familiares... Instrumentos de comunicación y de gobierno en la España del quinientos», en Antonio Castillo Gómez (comp.) (1999), Escribir y leer en el siglo de Cervantes, Barcelona, Gedisa, pp. 193-210.

GÓMEZ, Margarita (1985), «Crítica histórica y archivos: el caso de España en el siglo XVIII", Historia, Instituciones, Documentos, vol. 12, pp. 199-231.

GÓMEZ URDÁÑEZ, C. (1983), «La rejola: un material de construcción en Zaragoza en el siglo XVI», Artigrama, 1, pp. 85-112.

- (1987), Arquitectura civil en Zaragoza en el siglo XVI, Zaragoza, Ayuntamiento de Zaragoza, 2 vols.

- (1993), «La arquitectura civil en Aragón», en Las Artes en Aragón durante el reinado de Fernando el Católico: 1749-1516, Zaragoza, Institución «Fernando el Católico».

GÓmez URIEL, Miguel (1884-1886), Bibliotecas antigua y nueva de escritores aragoneses de Latassa, aumentadas y refundidas en forma de diccionario bibliográfico-biográfico por don Miguel Gómez Uriel, Zaragoza, Calisto Ariño.

GÓmEZ ZORRAQUINO, J. I. (1993), «La familia Hervás y el privilegio de veinte», Ivs Fvgit, 2, pp. 181 y ss.

GonZÁlez Antón, L. (1978), Las Cortes de Aragón, Zaragoza, Librería General.

- (1997), "Sobre la monarquía absoluta y el Reino de Aragón en el siglo XVI», en Esteban Sarasa y Eliseo Serrano (coords.) (1997), La Corona de Aragón y el Mediterráneo: siglos XV-XVI, Zaragoza, Institución «Fernando el Católico», pp. 369-410.

- (1999), «Aragón y Alfonso V: Modelo político institucional», en V Seminario de Historia Medieval: El Estado en la Baja Edad Media: Nuevas perspectivas metodológicas, Zaragoza, Universidad de Zaragoza, pp. 77-116.

GonZÁlez Miranda, Marina (1981), «Archivo Histórico Provincial de Zaragoza», en Estado actual de los archivos con fondos aragoneses, Madrid, Ministerio de Cultura, pp. 101-104.

Goody, Jack (1990), La lógica de la escritura y la organización de la sociedad, Madrid, Alianza.

Gotor, José Luis (1988), «Formas de comunicación en el siglo XVI (relación y carta)», en María Luisa López Vidriero y Pedro M. Cátedra (dirs.) (1988), Coloquio internacional: el libro antiguo español (1. ${ }^{\circ} 1986$. Madrid), Salamanca, Universidad; Madrid, Biblioteca Nacional / Sociedad Española de Historia del Libro, pp. 175-188. 
Gregorio Rocasolano, Antonio de (1923), «Desenvolvimiento de la cultura en Zaragoza desde el último tercio del siglo XVIII hasta fines del siglo XIX», Anales de la Universidad de Zaragoza, vol. v, n. ${ }^{\circ}$ IV, pp. 22 y ss.

Grupo de Archiveros Municipales de la Comunidad de Madrid (1997), Compilación de manuales de tipología documental de los municipios, Madrid, Dirección General de Patrimonio Cultural.

Guía de Zaragoza, o sea breve noticia de las antigüedades, establecimientos públicos, oficinas y edificios que contiene, Zaragoza, Imprenta y Librería de Vicente Andrés, 1860.

Hernández Calleja, Ana (1991), «Tipología de los procesos de Cortes», en Les Corts a Catalunya: Actes del Congrés d'Història Institucional (28-30 d'abril. 1988), Barcelona, Generalitat, pp. 62-70.

Hernández de Morejón, Sebastián (1809), Idea histórica de los principales sucesos ocurridos en Zaragoza durante el último Sitio, Valencia, Benito Monfort.

Hernando, Agustín (1996), La imagen de un pais: Juan Bautista Labaña y su mapa de Aragón (1610-1620), Zaragoza, Institución «Fernando el Católico".

Hespanha, A. M. (1989), Visperas del Leviatán: Instituciones y poder político (Portugal, siglo XVII), Madrid, Taurus.

HigGS, Edward (1996), «From medieval erudition to information management: the evolution of the archival profession", Archivum, XLIII, pp. 136-144. [Este volumen recoge las actas del XIII Congreso Internacional de Archivos (Pekín, 2-7 de septiembre de 1996).]

Ibarra RodrígueZ, E. (1909-1910), «Restos del antiguo archivo de la Diputación del Reino de Aragón existentes en el de la actual Diputación Provincial de Zaragoza", Anuari de l'Institut d'Estudis Catalans, pp. 90-129.

JiMÉNEZ CATALÁN, M. (1925a), Ensayo de una tipografía zaragozana del siglo XVII, Zaragoza, La Académica.

- (1925b), «Por los archivos regionales de Aragón», Universidad: Revista de cultura y vida universitaria, vol. 2 , n. ${ }^{\circ}$ 2, pp. 285-315; vol. 2, n. ${ }^{\circ}$ 3, pp. 555579; vol. 2, n. ${ }^{\circ}$ 4, pp. 751-784.

Kagan, Richard L. (2001), "Clío y la corona: escribir historia en la España de los Austrias», en R. Kagan y G. Parker (eds.) (2001), España, Europa y el mundo atlántico: Homenaje a John H. Elliot, Madrid, Marcial Pons, pp. 113-150.

LACARRA DUCAY, M. C. (1981), «Rasgos mudéjares en la pintura gótica aragonesa», en Actas del I Simposio Internacional de Mudejarismo, Teruel, Diputación Provincial de Teruel, pp. 71-93.

Lacueva Used, Francisco Javier (2002), La Diputación del Reino de Aragón en el año 1496, Zaragoza, F. J. Lacueva Used. 
Lalinde Abadía, J. (1962), La gobernación General en la Corona de Aragón, Zaragoza, Institución «Fernando el Católico».

- (1966), "La creación del derecho entre los españoles», Anuario de Historia del Derecho Español, 36, pp. 301-377.

- (1972-1973), «Las libertades aragonesas», Cuadernos de Historia Jerónimo Zurita, 25-26, pp. 7-36.

- (1974), Derecho Histórico Español, Barcelona, Ariel, 1974.

- (1980), "El pactismo en los Reinos de Aragón y de Valencia», en El pactismo en la historia de España, Madrid, Instituto de España, 1980, pp. 113-142.

- (1981), "Vida judicial y administrativa en el Aragón barroco», Anuario de Historia del Derecho Español, pp. 419-521.

Ledesma Rubio, María Luisa (1973), «Proceso de las Cortes de Maella de 1404», Estudios de Edad Media de la Corona de Aragón, IX, pp. 527-639.

LejEune, Louis François (1840), Sièges de Saragosse. Histoire et peinture des évenements qui ont eu lieu dans cette ville ouverte pendant les deux sièges qu'elle a soutenus en 1808 et 1809, París. [Existe traducción al español de Carlos Riba y García, Zaragoza, M. Escar, 1908.]

Lodolini, E. (1993), Archivistica, principios y problemas, trad. M. Costa Paretas, Madrid, Asociación Nacional de Archiveros, Bibliotecarios, Arqueólogos y Documentalistas.

- (1995), «El archivo del ayer al mañana», Boletín de la Anabad, vol. XLV, n. ${ }^{\circ}$ 1, pp. 39-50.

- (1997), "Archivi privati, archivi personali, archivi familiari, ieri e oggi», en Il futuro della memoria: Atti del Convegno internazionale di Studi sugli archivi di famiglie e di persone (Capri 9-13 settembre 1991), Roma, Ministero per i Beni Culturali e Ambientali, vol. 1, pp. 23-69.

- (2001), Storia dell'archivistica italiana: dal mondo antico alla metá del secolo XX, Milán, Franco Angelli.

LÓPEZ GONZÁleZ, Juan Jaime (1977), La ciudad de Zaragoza a finales del siglo XVIII (1782-1792), Zaragoza, Institución «Fernando el Católico».

López RodríGueZ, C. (1996), «El archivo Real y General del Reino de Valencia», Cuadernos de Historia Moderna, n. ${ }^{\circ}$ 17, pp. 175-192.

- (1997), «El archivo del Reino de Valencia: un modelo de archivo pasado, presente y futuro", en II Jornadas sobre cultura en la Comunitat Valenciana. Biblioteques, arxius i centres de documentació, vol. 2, pp. 445-457.

Lorente Junquera, M. (1960), La vista de Velázquez y Mazo, Madrid.

Lorenzo Cadarso, Pedro Luis (1996), Los conflictos populares en Castilla (siglos XVI-XVII), Madrid, Siglo XXI. 
LORENZO CADARSO, Pedro Luis (1999), La documentación judicial en la época de los Austrias: estudio archivistico y diplomático, Cáceres, Universidad de Extremadura.

- (2001), El documento real en la época de los Austrias (1516-1700), Cáceres, Universidad de Extremadura.

Macanaz, Melchor de (1879), Regalías de los Señores reyes de Aragón. Adiciones al discurso..., Madrid, Imprenta de la Revista de Legislación (Biblioteca Jurídica de Autores Españoles, 1).

MAISO, Jesús, y Rosa M. ${ }^{a}$ BLASCO (1984), Las estructuras de Zaragoza en el primer tercio del siglo XVIII, Zaragoza, Institución "Fernando el Católico»

MalHeiro DA SILVA, Armando, et al., (1998), Arquivistica: teoría e prática de uma ciência da informaçao, Oporto, Afrontamento.

Manuel, Miguel de (1933), "La alacena de Zurita», Cuadernos de Historia Jerónimo Zurita, X, pp. 747-780.

MaraVall, José Antonio (1972), Estado Moderno y mentalidad social, Madrid, Revista de Occidente, 2 vols.

Martin, Henri-Jean (1999), Historia y poderes de lo escrito, Gijón, Trea.

MARTín FuerTES, José Antonio (1997), «De la función histórica a la función integral de los archivos», Astorica, 16, pp. 411-427.

MARTín GaITE, C. (1975), Macanaz: otro paciente de la Inquisición, Madrid, Taurus, 2. ${ }^{\mathrm{a}}$ ed.

- (1999), El proceso de Macanaz: historia de un empapelamiento, Madrid, Espasa Calpe, pp. 183-205.

MarTín POzUelo, Mari Paz (1996), La construcción teórica en archivistica: el principio de procedencia, Madrid, Universidad Carlos III / Boletín Oficial del Estado.

Martínez Aloy, J. (1909), La Casa de la Diputación, Valencia.

- (1930), La Diputación de la Generalidad del reino de Valencia, Valencia, Diputación Provincial.

Martínez FerRando, J. E. (1962), «Aportación de datos acerca del archivo real de Barcelona y de sus archiveros durante los reinados de Juan II y Fernando el Católico", en Fernando el Católico y la cultura de su tiempo: V Congreso de Historia de la Corona de Aragón, Zaragoza, Institución «Fernando el Católico", pp. 77-109.

MARTínez FERRER, José María (1986), «La artillería y los ingenieros en la poliorcética del segundo sitio", en I Premio Los Sitios de Zaragoza, Zaragoza, Ayuntamiento de Zaragoza, pp. 23-64.

Martínez GarCía, Luis (1999), «El archivo de Simancas en el Antiguo Régimen: secreto, patrimonio, justificación y legitimidad real», Boletín de la $A N A B A D$, vol. XLIX, n. ${ }^{\circ} 2$, pp. 77-116. 
Mateu Ibars, M. D. (1986), "Cartas de Carlos I y Felipe II a Juan y Antonio Viladamor, archiveros de la Corona de Aragón, coetáneos de Zurita (15341556-1560)", en Congreso Nacional Jerónimo Zurita: su época y su escuela, Zaragoza, Institución «Fernando el Católico», pp. 413-423.

Mateu Llopis, Felipe (1944), Los historiadores de la Corona de Aragón bajo los Austrias, Barcelona, Horta.

MeSTRE, Antonio (1995), «La Erudición, del renacimiento a la Ilustración», Bulletin Hispanique, vol. 97, n. ${ }^{\circ}$ 1, pp. 213-232.

Moneva y Puyol, J. (1900), «Papeles viejos», Revista de Aragón, 1, pp. 243-246. Montagut Estragues, Tomás de (1987), El Mestre Racional a la Corona d'Aragó (1283-1419), Barcelona, Noguera.

Montaner Frutos, A. (1995), El Señal del Rey de Aragón: historia y significado, Zaragoza, Institución «Fernando el Católico».

- y D. NAvarro (1995), «La habilitación de infanzonía de Cristóbal Mañas de Aibar (1649): edición y estudio", Emblemata, 1, pp. 57-93.

Morales Arrizabalaga, J. (1986), La derogación de los Fueros de Aragón (17071711), Huesca, Instituto de Estudios Altoaragoneses.

Moreno Moreno, María Águeda (2000), Las cartas del concejo de Baeza (s. XIV$X V I)$, Jaén, Universidad de Jaén.

MORISON, Stanley (1972), Politics and Script: aspects of authority and freedom in the development of graeco-latin script from the sixth century B.C. to the twentieth century A.D., Oxford, Clarendon Press.

Muñoz Pomer, M. R. (1987), Origenes de la Generalidad Valenciana, Valencia, Conselleria de Cultura, Educació i Ciència.

Navarro Bonilla, D. (1996), «Aportación al estudio del archivo de la Diputación del Reino de Aragón: el expediente de Martín Maza de Lizana, archivero en 1745", Emblemata, 2, pp. 191-223.

- (1997), «Diversidad documental en el archivo de la Diputación del Reino de Aragón: estudio diacrónico", Emblemata, 3, pp. 185-216.

- (1998a), "La librería o "archivo alto" de la Diputación del Reino de Aragón (1593-1616). I: 1593-1605», Archivo de Filología Aragonesa, LIV-LV, pp. 4372.

- (1998b), "Certificaciones nobiliarias expedidas por el archivero de la antigua Diputación del Reino de Aragón", Emblemata, 4, pp. 263-286.

- (1999a), «Vicisitudes históricas de la documentación procedente del antiguo palacio de la Diputación del Reino de Aragón», Cuadernos de Aragón, 26, pp. 169-194.

- (1999b), "Competencias institucionales y reflejo archivístico: las series documentales de la Diputación del Reino de Aragón», en I Jornadas de Archivos 
Históricos en Granada (Granada, 27 y 28 de mayo de 1999), Granada, Ayuntamiento de Granada. [Se han publicado juntamente ponencias y comunicaciones en un CD-ROM.]

NAVARRO BONILLA, D. (1999c), "Cronistas aragoneses y escrituras: el método de la representación del Reino", Emblemata, 5, pp. 107-142.

- (2000a), Los fondos documentales del Archivo del Reino de Aragón: estudio y edición critica del inventario de José de Yoldi (1749-1750), Zaragoza, Institución "Fernando el Católico».

- (2000b), "Conservar la memoria escrita en el siglo XVIII: el archivo de la Bailía y Maestre Racional en Aragón», Signo: Revista de Historia de la Cultura escrita, 7, pp. 29-47.

- (2000c), «Escrituras, registros y poder municipal: las Ordinaciones de Zaragoza como fuente para la cultura escrita institucional», Revista de Historia Jerónimo Zurita, 75, pp. 189-212.

- (en prensa), «La librería o "archivo alto" de la Diputación del Reino de Aragón (1593-1616). II: 1606-1617».

- (ed.) (1999), Ceremonial de los asientos de los consistorios de los Diputados... [Edición facsímil del manuscrito ms. 799 de la Biblioteca Nacional de Madrid.]

- (2003), La imagen del Archivo: función y representaciones en España (siglos XVI$X V I I)$, Gijón, Trea.

Nigro, S. S. (1992), «El secretario», en El hombre barroco, Madrid, Alianza, pp. 115-135.

Olla Repetto, G. (1982), «La política arcivística di Alfonso IV d'Aragona», en La societá mediterranea all'epoca del Vespro: atti dell'XI Congreso di storia della Corona d'Aragona, Palermo, pp. 461-479.

Palacios Martín, Bonifacio (1994), "Imágenes y símbolos del poder real en la Corona de Aragón", en XV Congreso de Historia de la Corona de Aragón. Actas. Tomo I: El poder Real en la Corona de Aragón (siglos XIV-XVI), Zaragoza, Gobierno de Aragón, pp.191-229.

Palú Berna, María Dolores (1986), «La presencia de Jerónimo Zurita en Melchor de Macanaz (La utilización de citas zuridianas en sus tesis regalistas)», en Jerónimo Zurita: su época y su escuela, Zaragoza, Institución «Fernando el Católico», pp. 169-172.

Pantorba, B. de (1945), Sobre la vista de Zaragoza del Museo del Prado, Madrid. PARKER, Geoffrey (1998), La gran estrategia de Felipe II, Madrid, Alianza.

Parrilla Hernández, A. M. (1991), Documentos para la historia del Justicia de Aragón. Volumen II: Archivos aragoneses, Zaragoza, El Justicia de Aragón.

PASAMAR LÁZARO, José Enrique (1997), La cofradía de San Pedro Mártir en el distrito inquisitorial de Zaragoza, Institución «Fernando el Católico». 
Pascual de Quinto, Máximo (1916), La Nobleza de Aragón: Historia de la Real Maestranza de Caballería de Zaragoza, Zaragoza, Imp. de Carra.

Pastoureau, Michel (1985), "L'État et son image emblématique», en Culture et idéologie dans la genèse de l'état moderne: Actes de la table ronde organisée par le Centre National de la Recherche Scientifique et l'École Française de Rome, Rome, 15-17 octobre 1984, Roma, École Française de Rome, pp. 145-153.

Pedraza, Manuel J. (1993), Documentos para el estudio de la historia del libro en Zaragoza entre 1501 y 1521, Zaragoza, Centro de Documentación Bibliográfica Aragonesa.

- (1997), La producción y distribución del libro en Zaragoza: 1501-1521, Zaragoza, Institución «Fernando el Católico».

Peiró Arroyo, A. (1988), La defensa de los Fueros de Aragón (1707-1715), Zaragoza, Cortes de Aragón.

- (1998), Ignacio de Asso y la Historia de la Economía política de Aragón, Zaragoza, Institución «Fernando el Católico».

Peña Díaz, Manuel (1996), Cataluña en el Renacimiento: libros y lenguas (Barcelona, 1473-1600), Lérida, Milenio.

PéreZ, Antonio (ed.) (1979), Fori Aragonum, vom Codex von Huesca (1247) bis zur Reform Philipps II (1547): nach der Ausgabe Zaragoza 1476-1477: mit den handschriftlichen Glossen des Martin de Pertusa und mit Ergänzungen nach den Ausgaben Zaragoza 1542, 1548 und 1576, Vaduz (Liechtenstein), Topos Verlag.

Pérez Bustamante, Rogelio (1995), Historia de las instituciones públicas de Espa$\tilde{n} a$, Madrid, Universidad Complutense.

Pérez Latre, M. (1993), «Juntes de Braços i Diputació del General (1587-1593): Un presidi de Cavallers conspirants conta sa Magestad», Pedralbes: Revista d'História Moderna, vol. 13, n. ${ }^{\circ}$ 1, pp. 281-298.

- (1996), "Les torbacions de Catalunya (1585-1593): de les Corts a la Suspensió del nou redreç de la Diputació del General», Afers: Fulls de recerca i Pensament, vol. 23-24, pp. 59-98.

Pérez Marcos, Regina María (2001), «La imagen del Estado en la Edad Moderna», en R. M. Pérez Marcos (coord.) (2001), Teoría y práctica de gobierno en el Antiguo Régimen, Madrid, Marcial Pons, pp. 11-27.

PesCador Del Hoyo, María del Carmen (1981), «Por un archivo del Reino de Aragón", en Estado actual de los archivos con fondos aragoneses: Primeras Jornadas de Archivos, Madrid, Ministerio de Cultura, pp. 5-16.

PisTOLESE, S. (1934), «Les archives européenes du onziéme siècle à nos jours», en Guide International des Archives, Roma, pp. 23-27 (Bibliothèque des Annales Institutorum, IV, 3). 
Pons Guri, J. M. (1982), Actas de las Cortes generales de la Corona de Aragón de 1362-1363, Madrid.

PonZ, A. (1988), Viaje de España. Vol. XV: Aragón, Madrid, Aguilar. [Es reprod. facs. de la ed. de Madrid, Viuda de Ibarra, 1788-1794.]

Prieto Bernabé, José Manuel (2000), La seducción de papel: El libro y la lectura en la España del Siglo de Oro, Madrid, Arco Libros.

QuAdRADO, J. M. (1886), España: sus monumentos y artes: su naturaleza e historia. Aragón, Barcelona, Daniel Cortezo y Cía.

Ramos Loscertales, José María (1981), Los Fueros de Sobrarbe, Zaragoza, Institución «Fernando el Católico».

Rassow, P. (1933), «Fuentes de Zurita: La Colección Salazar y Castro y el Ms. B.N. 917», Cuadernos de Historia Jerónimo Zurita, 1, pp. 225-230.

Redondo Veintemillas, G. (1981a), «La Diputación del Reino de Aragón y el pintor Rafael Pertús (1621)», Seminario de Arte Aragonés, 33, pp. 189-194.

- (1981b), "Obras de restauración en el archivo del Reino de Aragón (1694)», Seminario de Arte Aragonés, 33, pp. 195-200.

- (1981c), «Una reforma de la capilla de la Diputación del Reino de Aragón en 1621», Seminario de Arte Aragonés, 33, pp. 201-208.

- (1999), «San Jorge, expansión y permanencia de un mito necesario», en Francisco Marco Simón, Alberto Montaner Frutos y Guillermo Redondo Veintemillas, El Señor San Jorge, patrón de Aragón, Zaragoza, Caja de Ahorros de la Inmaculada, pp. 49-96.

- y Guillermo FATÁs (1995), El señal de Aragón: el escudo y la bandera, Zaragoza, Diputación General de Aragón.

RIERA, Jaime (1999), Catálogo de memoriales e inventarios: siglos XIV-XIX: archivo de la Corona de Aragón, Madrid, Secretaría de Estado de Cultura.

Río PARRA, Elena del (1999), "La figura del secretario en la obra dramática de Lope de Vega", Espéculo. Revista de estudios literarios, 13. $<$ http://www.ucm.es/info/especulo/numero13/secretos.html>. Consulta: 27 de enero de 2002.

Roberge, Michel (1990), «Le système de classification des documents administratifs», Lligall, 2.

Rodríguez, Cristóbal (1992-1993), «Forma i Modo de componer i coordinar qualesquier archivos públicos, generales y particulares (1730)», Irargi, v, pp. 217-264.

Rodríguez De Diego, J. L. (1989), Instrucción para el gobierno del Archivo de Simancas (año 1588), Madrid, Dirección General de Bellas Artes y Archivos.

- (1998a), «Archivos del poder, archivos de la administración, archivos de la historia (s. XVI-XVII)», en Juan José Generelo y Ángeles Moreno López (coords.) 
(1998), Historia de los archivos y de la archivistica en España, Valladolid, Universidad de Valladolid, pp. 29-42.

Rodríguez de Diego, J. L. (1998b) «La formación del archivo de Simancas en el siglo XVI: Función y orden interno", en María Luisa López Vidriero y Pedro M. Cátedra (dirs.) (1998), El libro antiguo español, IV: Coleccionismo y bibliotecas (siglos XV-XVIII), Salamanca, Universidad de Salamanca / Patrimonio Nacional / Sociedad Española de Historia del Libro, pp. 519-549.

- (2000), «Significado del proyecto archivístico de Felipe II», en Alfredo Alvar Ezquerra (coord.) (2000), Imágenes históricas de Felipe II, Madrid, Centro de Estudios Cervantinos, pp. 183-196.

- y F. J. Álvarez Pinedo (1994), «Fondos históricos aragoneses del archivo de Simancas", Ivs Fvgit, 2, pp. 283-296.

Rubió y Cambronero, I. (1950), La Deputació del General de Catalunya en los siglos XV y XVI, Barcelona, Diputación Provincial de Barcelona.

RuIZ, Elisa (1999), «El poder de la escritura y la escritura del poder», en J. M. Nieto Soria (dir.) (1999), Orígenes de la Monarquía Hispánica: propaganda y legitimación (ca. 1400-1520), Madrid, Dykinson, pp. 275-312.

Russell, Peter (1996), «Archivists as Historians: The case of the Portuguese Fifteenth-Century Royal Chroniclers», en Alan Deyermond (ed.) (1996), Historical Literature in Medieval Iberia, Londres, Queen Mary and Westfield College (Department of Hispanic Studies), pp. 67-83.

SALAS BOSCH, J. de (1944), "Inventario del fondo documental que perteneció a Gerónimo Zurita», Boletín de la Real Academia de Bellas Letras de Barcelona, 27, pp. 79-177.

Salord Comella, S. (1956), «La Casa de la Diputación de la Generalidad de Aragón: noticias históricas», Estudios de Edad Media de la Corona de Aragón, VI, pp. 247-265.

San Vicente Pino, Á. (1980), Dos registros de tributaciones y fogajes de 1413 poblaciones de Aragón, correspondientes a las Cortes de los años de 1542 y 1547, Zaragoza, Institución «Fernando el Católico».

- (1981), Monumentos diplomáticos sobre los edificios fundacionales de la Universidad de Zaragoza, Zaragoza, Institución «Fernando el Católico».

- (1991), Lucidario de bellas artes en Zaragoza: 1545-1599, Zaragoza, Real Sociedad Económica Aragonesa de Amigos del País.

- (1992), «La defensión desta ciudat es tinta e paper y leyes», en J. Á. Sesma (coord.) (1992), Un año en la historia de Aragón: 1492, Zaragoza, Caja de Ahorros de la Inmaculada, pp. 405-434.

- (ed.) (1991), Años artísticos de Zaragoza: 1782-1833, sacados de los Años Políticos e Históricos que escribia Faustino Casamayor, Zaragoza, Ibercaja. 
San Vicente Pino, Á. y J. O. Crosby (1963), «Datos para la historia de Aragón: tres índices de 1566 cartas del siglo XVII, casi todas inéditas», Cuadernos de Historia Jerónimo Zurita, 14-15, pp. 93-198.

- y J. O. Crosby (1968-1969), «Más datos para la historia de Aragón: dos índices de otras 2788 cartas de los siglos XVI y XVII, casi todas inéditas», Cuadernos de Historia Jerónimo Zurita, 21-22, pp. 53-206.

SÁncheZ, J. M. (1913), Bibliografia Aragonesa del siglo XVI, Madrid, Imprenta Clásica Española, 2 vols.

SÁnchez Aragonés, L. M. (1994), Cortes, monarquía y ciudades en Aragón, durante el reinado de Alfonso el Magnánimo (1416-1458), Zaragoza, Institución «Fernando el Católico».

SÁnchez GonzÁlez, A. (1990), Documentación de la Casa de Medinaceli: el Archivo de los duques de Segorbe y Cardona, Madrid, Dirección de Archivos Estatales.

SÁNCHEZ De Movellán Torent, Isabel (1997), «La reforma de la Diputació del General e las ordinacions de 1432», en Josep Serrano Daura (coord.) (1997), El territori i les seves institucions històriques (Actes de les Jornades d'estudi conmemoratives del 650è aniversari de la incorporació definitiva del marge dret del riu Ebre a Catalunya —Ascó, 28-30 de novembre de 1997-), Barcelona, Fundació Noguera, vol. 2, pp. 893-912.

SANDRI, Leopoldo (1950), "Il "De archivis di Baldassare Bonifacio"», Notizie degli Archivi di Stato, pp. 95-111.

- (1956-1957), "Nicolo Giussiani e il suo Methodus archivorum», Bulletino dell'Archivio Paleografico italiano, II-III, pp. 330-342.

- (1958), «La storia degli archivi», Rassegna degli Archivi di Stato, pp. 109-134. [También en Archivum, XVIII (1968), pp. 101-113.]

- (1961), La letteratura archivistica dei seccoli XVII-XVIII (fonti e problemi), Nápoles, Archivo del Estado de Nápoles / Escuela de Paleografía.

Sans I Travé, J. M. (1998), «Els fons de l'arxiu de la Generalitat de Catalunya a l'época de Felip I de Catalunya-Aragó», en E. Belenguer (coord.) (1998), Congreso Internacional "Felipe II y el Mediterráneo», Barcelona, Fundación para los Centenarios de Carlos I y Felipe II, pp. 203-212.

- (dir.) (1994-1996), Dietaris de la Generalitat de Catalunya, a cargo de Luisa Cases i Loscos et al., Barcelona, Generalitat de Catalunya, 3 vols.

SANZ CAMAÑES, P. (1991), «La "fogueación" de 1646: fuentes y vías metodológicas para su estudio", en Metodología de la investigación científica sobre fuentes aragonesas, Zaragoza, Instituto de Ciencias de la Educación, vol. 6, pp. 491-501.

- (1992), «La hacienda del Reino de Aragón a través de los "libros de cuentas del General" durante el seiscientos: metodología para su estudio», en Meto- 
dología de la investigación cientifica sobre fuentes aragonesas, Zaragoza, Instituto de Ciencias de la Educación, vol. 7, pp. 479-490.

Sanz Camañes, P. (1997), Política, hacienda y milicia en el Aragón de los últimos Austrias entre 1640 y 1680, Zaragoza, Institución «Fernando el Católico».

Sarasa SÁnchez, E. (1979), Las Cortes de Aragón en la Edad Media, Zaragoza, Guara.

- (1986), Aragón en el reinado de Fernando I (1412-1416): Gobierno y administración. Constitución politica. Hacienda Real, Zaragoza, Institución «Fernando el Católico».

- (1988), "Las cortes de Aragón en la Edad Media», en Las Cortes de Castilla y León en la Edad Media, Valladolid, Cortes de Castilla y León, pp. 493-542.

- (1989), «Las "actas de cortes" medievales como fuentes de investigación: aspectos metodológicos», en Metodología de la investigación científica sobre fuentes aragonesas, Zaragoza, Instituto de Ciencias de la Educación, vol. 4, pp. 321357.

- (1991), «Las Cortes de Aragón en la Edad Media: estado de la cuestión y planteamiento general», en Les Corts a Catalunya: actes del congrés d'història institucional (28, 29 i 30 d'abril de 1988), Barcelona, Generalitat de Catalunya, pp. 296-301.

Savall y Dronda, P., y S. Penén y Debesa (1866), Fueros, Observancias y actos de Cortes del Reino de Aragón, Zaragoza, Imp. Francisco Castro y Bosque, 2 vols. [Existe ed. facs. a cargo de Jesús Delgado Echeverría et al., Zaragoza, El Justicia de Aragón, 1991.]

SCHellenberG, Theodore R. (1961), Técnicas descriptivas de archivos, Córdoba (Argentina), Universidad Nacional.

Serrano Montalvo, A. (1995), La población de Aragón según el fogaje de 1495, Zaragoza, Institución «Fernando el Católico», 2 vols.

Sesma Muñoz, J. Á. (1973), Relaciones epistolares de la Diputación del Reino de Aragón en los ejercicios 1484-85 y 1485-86, Zaragoza, Tesina de licenciatura.

- (1976), «Las Generalidades del reino de Aragón: su organización a mediados del siglo XV", Anuario de Historia del Derecho Español, XLVI, pp. 393-467.

- (1977), La Diputación del Reino de Aragón en la época de Fernando II (14791516), Zaragoza, Institución "Fernando el Católico».

- (1979), «Trayectoria económica de la hacienda del Reino de Aragón en el siglo XV», Aragón en la Edad Media: Economía y sociedad, II, pp. 203-244.

- (1981), «Instituciones parlamentarias del Reino de Aragón en el tránsito a la Edad Moderna", Aragón en la Edad Media, IV, pp. 221-234.

- (1983), «La fijación de fronteras económicas entre los estados de la Corona de Aragón», Aragón en la Edad Media, v, pp. 141-163. 
Sesma MuÑoz, J. Á. (1987a), «Estado y nacionalismo en la Baja Edad Media», Aragón en la Edad Media, 7, pp. 245-273.

- (1987b), El establecimiento de la Inquisición en Aragón: (1484-1486): Documentos para su estudio, Zaragoza, Institución «Fernando el Católico».

- (1992), «Documentos fiscales medievales: metodología para su explotación científica», en Metodología de la investigación científica sobre fuentes aragonesas, Zaragoza, Instituto de Ciencias de la Educación, vol. 7, pp. 123-158.

- y J. A. Armillas (1991), La Diputación de Aragón: El gobierno aragonés, del Reino a la Comunidad Autónoma, Zaragoza, Oroel.

- y E. SARASA (1976), Cortes del Reino de Aragón (1357-1451): fragmentos y extractos de procesos desaparecidos, Valencia, Anubar.

Solano, Francisco de, Margarita Gómez Gómez y Manuel Romero Tallafigo (1986), Archivo General de Indias: Ordenanzas, edición facsimil y estudios preliminares, Sevilla, Junta de Andalucía (Dirección General del Libro).

Solano CAMÓn, Enrique (1987), Absolutismo y pactismo (1626-1652): los aragoneses ante la Unión de Armas, Zaragoza, Institución "Fernando el Católico».

- (1992), «Las "relaciones" entre la Monarquía y Aragón en la España de los Austria: fuentes y metodología para su estudio", en Metodología de la investigación cientifica sobre fuentes aragonesas, Zaragoza, Instituto de Ciencias de la Educación, vol. 7, pp. 373-429.

- y Porfirio Sanz Camañes (1998), «La contribución de Aragón en las empresas militares al servicio de los Austrias", Stvdia Histórica. Historia Moderna, 18, pp. 237-264.

Stradling, R. A. (1989), Felipe IV y el gobierno de España: 1621-1665, Madrid, Cátedra.

TOMÁs y VAliente, F. (1982), Gobierno e Instituciones en la España del Antiguo Régimen, Madrid, Alianza.

- (1987), Manual de Historia del Derecho Español, Madrid, Tecnos, 4. ${ }^{\mathrm{a}}$ ed.

- (1997a), «El gobierno de la Monarquía y la administración de los reinos de la España del siglo XVII», en Obras completas, Madrid, Centro de Estudios Políticos y Constitucionales, vol. v, pp. 3683-3874.

- (1997b), "La venta de oficios en Indias, y en particular la de escribanías», en Obras completas, Madrid, Centro de Estudios Políticos y Constitucionales, vol. v, pp. 4231-4236.

Torre y del Cerro, A. de la (1923), Orígenes de la Deputació del General de Catalunya, Barcelona.

Tusell, Javier (1986), «La cultura: botín de guerra», Lápiz: revista mensual de arte, vol. 4 , n. ${ }^{\circ} 36$, pp. 29-32. 
Ubieto Arteta, A. (1959), «Procesos de la Inquisición de Aragón», Revista de Archivos, Bibliotecas y Museos, vol. LXVII, n. ${ }^{\circ}$ 2, pp. 549-599.

Udina Martorell, F. (1982), «El Archivo de la Corona de Aragón y sus fondos sobre Cortes», En la España Medieval: Estudios en memoria del profesor D. Salvador de Moxó, vol. 2, pp. 681-694.

- (1986), Guía histórica y descriptiva del Archivo de la Corona de Aragón, Madrid, Ministerio de Cultura (Dirección de los Archivos Estatales).

— (1991), «Importància i influència de la Cort General i la Diputació del General a Catalunya», en Les Corts a Catalunya: actes del congrés d'història institucional (28, 29 i 30 d'abril de 1988), Barcelona, Generalitat de Catalunya, pp. 129-141.

URQUijo y URQuijo, María Jesús (1982), «Fondos de archivos privados y semipúblicos en los Archivos Histórico Provinciales», Boletín de la ANABAD, vol. XXXII, n. ${ }^{\circ} 1-2$, pp. 65-70.

Valenzuela la Rosa, José (ed.) (1908), Los sitios de Zaragoza: diario de Casamayor, Zaragoza, Abadía y Capapé.

VÁlgoma y Díaz-VArela, Dalmiro de la (1959), «Los Ayala: una genealogía de archiveros», Revista de Archivos, Bibliotecas y Museos, vol. LXVII, n. ${ }^{\circ}$ 1, pp. 105-118.

VARGAS ZÚNIGA, A. (1953), Indice de la colección de don Luis Salazar y Castro: [...] tomo IX: Cartas y documentos de Jerónimo Zurita, cronista de Aragón, y de sus parientes (1418-1626), Madrid, Maestre.

VICENTE DE CuÉLLAR, Benito (1988), «Las pretensiones procesales de infanzonía en el Derecho foral aragonés», en I Seminario sobre Heráldica y Genealogía, Zaragoza, Institución «Fernando el Católico», 1988, pp. 23-44.

ViÑAZA, Conde de la [Cipriano Muñoz y Manzano] (1904), Los cronistas de Aragón, Madrid, Imprenta de los hijos de M. G. Hernández. [Existe ed. facs, con introd. de María Carmen Orcástegui Gros y Guillermo Redondo Veintemillas, Zaragoza, Cortes de Aragón, 1986.]

VisCEGLIA, María Antonieta (2000), "Archivisti e storici di fronte agli archivi di famiglia: note conclusive», en Laura Casella y Roberto Navarrini (eds.) (2000), Archivi nobiliari e domestici: conservazione, metodologie di riordino e prospettive di ricerca storica, Udine, Forum, pp. 331-347.

Ximénez de Embún GonzÁlez, A. (1986), «Pleitos civiles de la Audiencia de Aragón hasta 1834», en Guillermo Pérez Sarrión (ed.) (1986), El Patrimonio documental aragonés y la Historia, Zaragoza, Diputación General de Aragón, pp. 449-464.

- (1992), «Fuentes documentales para la historia del Justicia de Aragón en el Archivo Histórico Provincial de Zaragoza», Revista de Historia Jerónimo Zurita, 65-66, pp. 155-164. 
XiméneZ de Embún GonZÁlez, A. (1995), «Inventario de las alhajas de la casa de la Real Audiencia del Reino de Aragón y de la capilla de la cárcel de corte (1734)», Emblemata, 1, pp. 226-244.

XiméneZ de EMbún y Val, T. (1901), Descripción histórica de la antigua Zaragoza y sus términos municipales, Zaragoza, Librería de Cecilio Gasca. 



\section{ÍNDICE}

ABREVIACIONES ............................................................

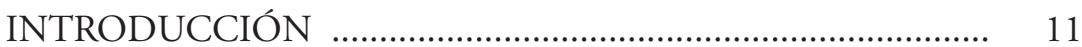

1. LA DIPUTACIÓN DEL REINO DE ARAGÓN ................... 29

1.1. Fin y evolución histórica ................................................. 29

1.2. Órganos ….................................................................. 44

1.3. Funciones …............................................................. 58

2. PRODUCCIÓN Y GÉNESIS DOCUMENTAL .................. 71

2.1. Procedimiento administrativo general.............................. 71

2.1.1. Funcionarios actuantes ........................................ 72

2.1.2. Actividades ......................................................... 75

2.2. Identificación de series documentales ............................. 77

2.3. Propuesta de cuadro de clasificación del fondo ................ 112

3. EL ARCHIVO DE LA DIPUTACIÓN DEL REINO DE ARAGÓN

3.1. Creación del archivo del reino (siglo XV) ......................... 120

3.2. Ubicación y descripción del archivo (siglos XVI-XVII) ....... 124

3.3. El archivo de la Diputación del reino de Aragón en el siglo XVIII

3.4. Avatares, incendio y dispersión del archivo del reino ....... 139

4. EL ARCHIVERO Y LOS RESPONSABLES DE LA MEMORIA ESCRITA …............................................................ 147

4.1. Figura y funciones del archivero .................................. 147 
4.2. Nómina de archiveros ............................................... 149

4.2.1. Los archiveros bajo la administración austríaca .... 150

4.2.2. Los archiveros bajo la administración borbónica .. 158

4.3. Cronistas y archiveros o la regencia del archivo como culminación del cursus honorum

5. LA ORGANIZACIÓN DE LOS DOCUMENTOS ............ 167

5.1. ¿Por qué se organizan los documentos? .......................... 167

5.2. Instrumentos de descripción documental ...................... 171

5.2.1. Inventarios generales de series documentales ........ 172

5.2.2. Inventarios de series específicas ........................... 183

5.2.3. Índices y resúmenes de los registros de actos comunes

5.3. Documentación administrativa indicativa del contenido .. 194

5.3.1. Hojas de remisión ............................................... 195

5.3.2. Registros de entrada y salida de escrituras ............. 196

5.3.3. Signaturas e índices internos de registros .............. 197

6. LA CONSULTA DE LA DOCUMENTACIÓN DEL ARCHIVO 199

6.1. Usuarios internos ......................................................... 201

6.2. Usuarios externos ..................................................... 209

6.3. Modos de consulta ................................................... 216

6.3.1. Certificaciones expedidas por el archivero ........... 216

6.3.2. Consultas externas mediante envío ...................... 219

6.4. Negligencias en la tramitación y custodia documental ..... 222

7. VALOR Y FINES DEL ARCHIVO DEL REINO ................ 229

7.1. Los valores de registros y escrituras para la institución productora

7.2. El valor de lo escrito para el gobierno y la administración 232

7.3. El valor de lo escrito para la historia y la propaganda del reino

7.4. El valor del archivo en el siglo XVIII para la Monarquía ...

245 
Este libro se terminó de imprimir

en los talleres de Cometa, S.A.

de Zaragoza, el día 10 de Febrero de 2004

$$
\approx
$$


ste libro analiza la producción, gestión y consulta de la documentación generada por la Diputación del reino de Aragón y custodiada en el archivo del reino a través del estudio de sus estructuras, órganos, funciones y su evolución mediante la aplicación del método archivístico de reconstrucción del orden originario de los documentos. La institución, emanada de las Cortes, rigió buena parte de la vida política y económica del antiguo reino desde finales del siglo xiv hasta comienzos del xVIII, con el cese de su actividad decretado tras la Nueva Planta borbónica. Su funcionamiento burocrático se sostuvo en una amplia práctica administrativa que comprendia, por una parte, los procedimientos de creación y tramitación de los documentos y, por otra, su natural y necesario complemento en el propio archivo del reino de Aragón. Éste se convirtió en un elemento clave en la vida de la Diputación, que lo utilizó de forma simultánea al servicio de sus actividades de gobierno, de administración y para fundamentar la construcción historiográfica oficial del reino.

La mayor parte de los documentos que se salvaron del segundo sitio francés de Zaragoza (1809) se halla actualmente en el archivo de la Diputación Provincial de Zaragoza.

En suma, este libro profundiza en la realidad documental de uno de los principales depósitos de información para recuperar la historia institucional del reino, y ejemplo de la necesaria vinculación entre el ejercicio del poder y el desarrollo de la escritura oficial organizada en torno a las políticas de archivo del Antiguo Régimen.
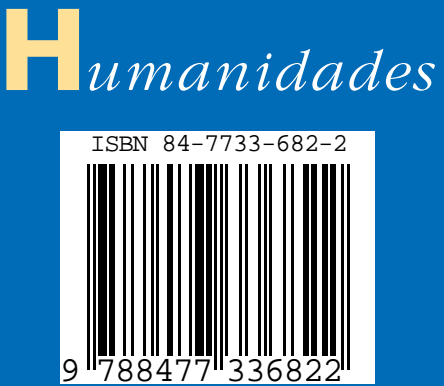